\title{
SCRIPTA ISLANDICA
}

\author{
ISLÄNDSKA SÄLLSKAPETS \\ ÅRSBOK 71/2020
}

\author{
REDIGERAD AV \\ LASSE MÅRTENSSON OCH VETURLIĐI ÓSKARSSON
}

\author{
under medverkan av \\ Pernille Hermann (Århus) \\ Else Mundal (Bergen) \\ Guðrún Nordal (Reykjavík) \\ Heimir Pálsson (Uppsala) \\ Henrik Williams (Uppsala)
}

UPPSALA, SWEDEN 
(C) 2020 respektive författare (CC BY)

ISSN 0582-3234 (tryckt)

ISSN 2001-9416 (digitalt)

Sättning: Ord och sats Marco Bianchi

urn:nbn:se:uu:diva-429326

http://urn.kb.se/resolve?urn=urn:nbn:se:uu:diva-429326

DOI: $10.33063 /$ diva-429326 


\section{Innehåll}

HenRik Williams, Jan Axelson in memoriam $\ldots \ldots \ldots \ldots \ldots .5$

BRYNJA PORGEIRSDÓTTIR, The Language of Feeling in Njáls saga and Egils saga: Construction of an Emotional Lexis .......... 9

Katarzyna Anna Kapitan, Medieval Poetry in Post-medieval Manuscripts: New Perspectives on the Transmission History of Griplur .............................. 51

Lise GJedssø Bertelsen, Om Taustaven fra Pingvellir, Island: Skálholtbispen Ísleifur Gissurarsons hyrdestav? . . . . . . . . . . . . . 99

Már Jónsson, An Icelandic Noctuary of 1794 . . . . . . . . . . . . . . 123

Ebbe Nyborg And Jette Arneborg, Christian Medieval Art in Norse Greenland: Crosses and Crucifixes and their European Antecedents ................................. 155

\section{Recension}

Olof SunDQvist, Rec. av Triin Laidoner. Ancestor Worship and the Elite in Late Iron Age Scandinavia. A Grave Matter . . . . . . . . . 177

\section{Isländska sällskapet}

Agneta Ney \& Marco Bianchi, Berättelse om verksamheten under 2019 . . . . . . . . . . . . . . . . . . . . . . . . . . . . . . 185

Tack till våra granskare under åren $2011-2020$. . . . . . . . . . 187

Författarna i denna årgång $\ldots \ldots \ldots \ldots \ldots \ldots \ldots \ldots$. . . . . . . . 189 



\title{
Jan Axelson in memoriam
}

\author{
HENRIK WILLIAMS
}

Jan Axelson, Isländska sällskapets skattmästare, avled 17 november i fjol, 59 år gammal. Som en av dem som har känt Jan längst känner jag mig kallad att skriva några ord om honom. Mina första minnen stammar från cirka 1980 då en ung man som visade sig vara Jan började hälsa på mig när vi stötte ihop, utan att jag kände honom. Förklaringen var en gemensam vän, Ola Larsmo, som läste svenska och teologi tillsammans med Jan och som hade pekat ut mig som någon som var intresserad av fornnordiska, ett av Jans intressen. Genom Ola har jag fått veta en del om Jans studietid. Han var en lysande student som olika lärare verkligen uppmärksammade som en studiebegåvning av första rang. Redan under sin gymnasiegång i Köping uppenbarades hans begåvning, vilket han aldrig själv lät påskina men som framgick genom olika historier han berättade under åren. Växte upp gjorde han i Kolsva som enda barnet till två äldre föräldrar och en exemplarisk son måste han ha varit under hela deras livstid. Med tiden kom han att sköta om mer och mer av det praktiska åt dem och mot slutet tog han tjänstledigt i perioder för att kunna hjälpa till på plats. När hans mamma dog följde pappan efter inom kort och de begravdes i samma grav vid Malma gamla kyrka där nu också Jans aska vilar.

Jans och mina vägar möttes på riktigt när han började på C-seminariet för att skriva uppsats. Ämnet han valde med Lena Peterson som handledare var ortnamnet Barkestorp i Småland. Det tog honom flera år att slutföra uppsatsen, men den är också ett riktigt lärdomsprov. Fördröjningen hade sin förklaring delvis i att Jan ägnade sig åt annat men i ännu högre grad tror jag i karaktärsdrag som alltmer kom att prägla hans liv. Jan var extremt plikttrogen, till den grad att det påverkade socialt umgänge och

Williams, Henrik. 2020. Jan Axelson in memoriam.

Scripta Islandica 71: 5-8.

(C) Henrik Williams (CC BY)

DOI: $10.33063 /$ diva-429318 


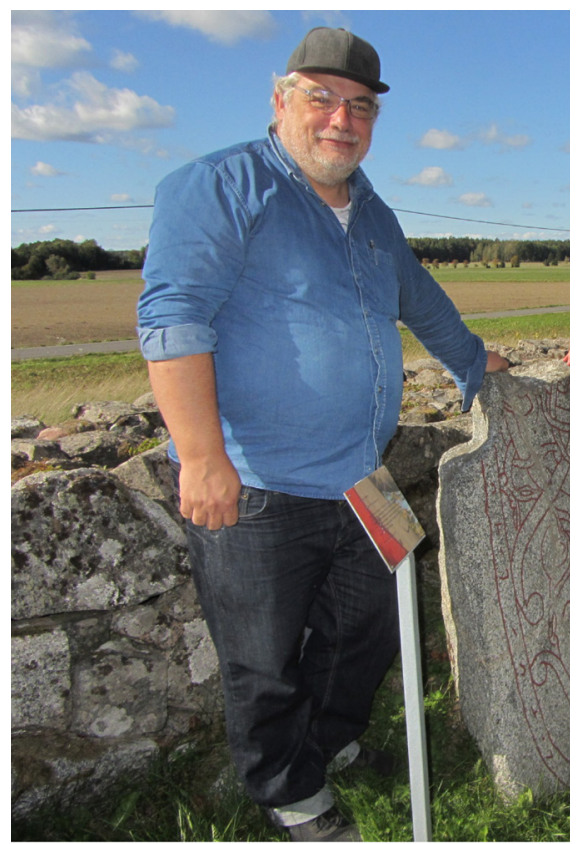

Jan Axelson med runsten U 1170 vid Vittinge kyrka. Foto: Gunnel Ollas, 2018.

yrkeskarriär. Under studietiden kom kurskraven först och sällskapet med vänner och bekanta blev lidande trots att Jan var mycket social och gärna deltog i olika arrangemang. Egna initiativ tog han däremot inte ofta nog och så småningom ledde det till en viss ensamhet, även om hans umgänge var långt större än någon av oss visste eftersom han för andra bekanta aldrig berättade vem han hade träffat.

Jan arbetade under flera år på Runverket vid Riksantikvarieämbetet och hade nog hoppats få fortsatt anställning där eller på Svenskt diplomatarium vid Riksarkivet som han också arbetade vid under en period. Hans kompromisslösa noggrannhet vid utförandet av alla arbetsuppgifter ledde dock till en alltför låg produktivitet. Tillsammans med Svante Lagman och mig bildade Jan en runologisk doktorandtrio, även om han antogs senare än vi andra två. Hans avhandling skulle handla om fornärvda diftonger i runsvenskan. Ämnet är ytterst komplext och Jan kom aldrig längre än till en omfattande materialinsamling som dessutom gick förlorad genom datorproblem. En kortare analystext som jag fick läsa visade dock att han var på rätt spår. De tidigare nämnda problemen med att få saker ur 
händerna gjorde sig allt mer gällande, och den värdefulla inventering av mellansvenska runristare han publicerade 1993 tog mycket längre tid än beräknat.

Sin fasta yrkesbas hade Jan som studievägledare vid Institutionen för nordiska språk i Uppsala. Han slutförde sin ämneslärarutbildning men arbetade såvitt jag vet aldrig på högstadiet eller gymnasiet. Vid Institutionen var han en tid universitetsadjunkt tills hans tjänst ändrade beskrivning, och som sådan hade han viss undervisning men det var som administratör hans egentliga insats bestod. Efter att heltidsadjunkturen förvandlats till en halvtidstjänst fortsatte Jan arbeta lika mycket om inte mer, men han hann uppleva glädje att sista året få gå upp på heltid igen. Efter hans död sades det inte bara på skämt att hans anställning fick ersättas av tre heltidstjänster. Jan satt också på jobbet minst sex dagar i veckan och ofta inpå sena kvällen. Jag brukade övertala honom att följa mig en bit på vägen hem eftersom vi bodde åt samma håll. Förutom dessa promenader och ganska många samtal på tjänsterummen umgicks vi inte mycket privat, förutom på julafton då Jan under många år var vår gäst vid jullunchen, under Kalle Anka på teve efteråt och julbönen i Domkyrkan.

I kyrkan gick Jan varje vecka. Han växte upp i Missionskyrkan men lämnade den och gick de sista åren mest i Vindhemskyrkan (Svenska kyrkan) där han också jordfästes den 7 februari i år. Hans kyrkliga bakgrund märktes inte minst genom en imponerade bibelsprängdhet. Jans kunskaper omfattade mycket mer än så och han verkade ibland komma ihåg allt han lärt sig i skolan eller på universitetet. Så tog han ibland kurser flera gånger och gick inte upp i förhör förrän han hade fäst varenda detalj i minnet. En gång fick han väl godkänt på fördjupningskursen i fornisländska, men eftersom han inte varit formellt berättigad att gå kursen tenterade han om för annan lärare när han skaffat sig sin behörighet.

Obehöriga studenter var han annars väl bekant med, inte minst eftersom jag envisades att låta sådana följa mina kurser. Efter att ha gett mig en sträng tillrättavisning för mina synder löste han alltid de administrativa problem jag hade åsamkat på bästa sätt för studenten ifråga, dock utan att någonsin tumma på reglerna. De tusentals studenter, inte minst de utländska, som under årtiondena har haft förmånen att åtnjuta Jans hjälpsamhet vet vad jag talar om. Så fylldes också Ihresalen av studenter som jämte kollegorna deltog i minnesstunden efter hans överraskande dödsfall. Som prästen sade vid hans också mycket välbesökta jordfästning var det inte en tillfällighet att Jan dog av för stort hjärta.

Jan var en tjänsteman av gamla skolan och hade bland sina många jobb 
också vikarierat på fakultetskansliet. Han hade bestämmelser på sina fem fingrar och var en tillgång både vad gällde det som för tillfället gällde och det som en gång rådde. Dessutom var han vår främste institutionshistoriker som vårdade sig om minnen och vid ett tillfälle räddade den dyrbara samlingen av fornisländsk litteratur från att införlivas med det gemensamma biblioteket $\mathrm{i}$ kvarteret. Många gånger har jag skänkt hans framsynthet en tacksamhetens tanke.

Jan satte aldrig sig själv i första rummet och utmärktes av en för långt driven ödmjukhet som kan ställa till problem den med. Många hedersbevis skämdes han inte bort med, men jag vet att han var stolt över att bli vald till Isländska sällskapets skattmästare, en syssla han skötte med omsorg. Jag hade själv detta uppdrag 1986-92 och ansvarade de första åren också för medlemsregister samt utskick av kallelser och årsskrift till de över 200 medlemmarna. Jan ställde flera gånger upp och hjälpte till med att stoppa Scripta Islandica i kuverten, liksom man kunde räkna med att han hjälpte till med röjningen efter postseminarier och sexor.

Trogen sin frikyrkliga bakgrund var Jan livslång nykterist. Såvitt jag vet drack han alkohol bara en gång. Jag hade av runologen, numera vintillverkaren Claiborne Thompson i Kalifornien fått en flaska av deras finaste vin, The Runestone Wine. Jag sparade flaskan ett par år men öppnade den tillsammans med några andra runforskare för att fira en befordran. Till min stora förvåning gjorde Jan ett undantag och ville testa runvinet, han också. Till stor besvikelse för oss andra hade vinet hunnit bli dåligt och ingen ville dricka det. Utom Jan som tömde sin lilla skvätt; hur skulle han kunna ha vetat hur vin ska smaka?

Kanske är det ett passande slut på minnesordet över en oerhört principfast människa som aldrig gjorde stort väsen av sig och kunde göra undantag när det kom till kritan. Jag saknar honom nästan varje dag, hans vänlighet och hjälpsamhet, hans integritet och humoristiska allvar, men mest av allt hans rena godhet. Människor som Jan Axelson är alltför sällsynta.

Henrik Williams

Uppsala universitet

Institutionen för nordiska språk

ORCID iD 0000-0003-1738-7072 


\title{
The Language of Feeling in Njáls saga and Egils saga: Construction of an Emotional Lexis
}

\author{
BRYNJA PORGEIRSDÓTTIR
}

\section{Introduction}

Íslendingasögur (Sagas of Icelanders) are notorious for the apparent emotional reticence of their narrative style. As a rule, the narrative voice is externally focalised and emotional expression in the prose is mainly implicit; feelings are communicated through behaviour, physical reactions, and indirect allusions, and most often need to be inferred (Sävborg 2007: 246; Sif Rikhardsdottir 2017: 71-78; Miller 1992: 94-97). ${ }^{1}$

For example, the feelings of the Norwegian king's mother, Gunnhildr, and the erotic love she holds for the Icelandic chieftain Hrútr at the beginning of Brennu-Njáls saga, are never explicitly stated with emotion words. Instead, her passionate emotions are conveyed by her action and gestures, by the many gifts she gives Hrútr, and her locking herself in her chambers with him for two weeks after announcing to him: "Pú skalt liggja í lopti hjá mér í nótt, ok vit tvau saman" (Brennu-Njáls saga 1954: 15), 'You shall lie in my chambers tonight, and us two together'. Furthermore, her

\footnotetext{
${ }^{1}$ Concerning the laconic saga-style in general, the chapter on Íslendingasögur in Íslensk stílfraðði (Porleifur Hauksson and Pórir Óskarsson 1994) remains one of the most comprehensive analysis. Sävborg (2017) furthermore provides a thorough discussion on external focalization in this context.

${ }^{2}$ Page numbers in brackets refer to the Íslenzk fornrit editions. All translations in this essay are my own.
}

Porgeirsdóttir, Brynja. 2020. The Language of Feeling in Njáls saga and Egils saga:

Construction of an Emotional Lexis. Scripta Islandica 71: 9-50.

(C) Brynja Porgeirsdóttir (CC BY)

DOI: $10.33063 /$ diva-429319 
feelings are indicated by her gestures as she kisses Hrútr while casting a spell on him when he leaves her: that he will not be able to have any physical pleasure with the woman he plans to marry (21). Similar style is applied in the description of teenage Egill's wrath in Egils saga, when his brother announces to Egill's disappointment that there is no chance that he will take him abroad with him (Egils saga 1933: 102). Egill's rage at this is not communicated with emotion words, but it is tangible and vividly expressed with his subsequent sabotage of his brother's ship, and his threats of doing more harm towards Pórólfr if he didn't take him away with him (102-3). In the background, a storm rages in the black night, functioning as a reflection of Egill's turbulent emotional state (102-3).

Nevertheless, emotion words are indeed found in Íslendingasögur. However, the extent of the part they play in the sagas' depiction of feelings what explicit emotion words are used, how, by whom, and in what context - has not been the focus of studies on emotions in saga literature. While a variety of studies on emotion terms have been conducted within classical studies (Kaster 2005) and surveys of texts of the medieval West (Rosenwein 2008, 2010), a comprehensive study of Old Norse emotion vocabulary, and how it is used, has yet to be made. In the absence of such a lexical investigation, the question arises as to what extent assertions such as that of Kirsten Wolf, that Íslendingasögur are "poor in emotional vocabulary" (Wolf 2014: 143), can be taken as truisms - or William Ian Miller's claim that readers of the sagas are "seldom assisted by native emotions words" (Miller 1992: 107). Without a point of comparison, it cannot be ascertained with clarity what "poor" or "seldom" signify in this context. This drives a closer inquiry regarding the extent feelings are expressed with emotion words in the sagas and what function these words have within them.

This subject has been approached to some extent. In his 1994 essay, "Emosjon og aksjon i Njáls saga", Vésteinn Ólason explores the theme of honour in Njáls saga through nouns that refer to emotions. Vésteinn finds only fourteen nouns in the saga that describe emotions. These nouns, he finds, are used 117 times in the saga, and the majority are words for friendship: vinr 'friend', vinátta 'friendship', and vinfengi 'friendship'. Vésteinn concludes that "[f]ølelser sjelden blir nevnt med ord, og at ordforrådet ikke er særlig nyansert [...] Njáls saga bruker et enkelt ordforråd for a beskrive emosjoner" (1994: 164) ('Emotions are rarely mentioned with words and the vocabulary is not very nuanced [...] Njáls saga uses a simple vocabulary to describe emotions'). Vésteinn does not say why he limits his investigation to nouns, nor explain the criteria behind the selection of words. For example, 
his study does not include the nouns hraesla 'fear', hugleysi 'cowardice', áhyggja 'anxiety' or 'worry', œði 'rage', ópokki 'hostility', blíða 'affection', and many others found in the saga, as seen in Table 2 below.

In her essay, "Learning to Feel in the Old Norse Camelot?", Carolyne Larrington explores whether translated romances influenced the emotional style of native Old Norse sagas and includes a "preliminary analysis of emotion lexis" in different genres of Old Norse literature with examples from poetry and prose (Larrington 2015: 86). As Larrington notes, "it is evident that Old Norse already possessed a full lexis of emotion [...] in the early thirteenth century", which was capable of expressing both basic and complex feelings (86). Her preliminary analysis "indicates that a more intensive lexical investigation would be fruitful" (86). ${ }^{3}$

Larrington's conclusion here serves as a premise for the following analysis. In what follows, the emotional vocabulary of Egils saga and Njáls saga is listed and analysed to assess the significance and function of emotion words in the two sagas. In the absence of comprehensive studies on the topic, the prerequisite for reaching this goal is to define the design and methods for the construction of such a lexicon. In this essay, a method of building lexicons of emotion words extracted from these two sagas is laid out. The lexicons are presented, followed by an analysis and conclusions. The aim is to probe what themes emerge from the lexicons and what they reveal about the use of emotion words within the texts.

\section{Method}

To understand how much emotion words weigh in the depiction of feelings in Njáls saga and Egils saga, the sagas were scrutinized for words expressing an emotional state. ${ }^{4}$ This entailed a close reading of the

\footnotetext{
${ }^{3}$ See also Daniel Sävborg's monumental study of love in Old Norse literature, which includes an investigation of the words used for love in Íslendingasögur (Sävborg 2007: 36-43). Furthermore, Sif Rikhardsdottir (2017: 64-71) discusses the function of a handful of emotion words in Egils saga. Edel Porter and Teodoro Manrique Antón (2015) investigate the occurrences of words that include somatic markers of emotion in a variety of Old Norse texts.

${ }^{4}$ The editions used to build the lexicon were edited by Jón Torfason and others, published by Svart á hvítu in 1985. This is because the texts of the Svart á hvítu editions form the searchable database Mörkuð islensk málheild: Fornrit and are available in digital form. In the case of Njáls saga, this edition is based on the 1875-1889 edition of Konrád Gíslason
} 
standard editions of the sagas, word for word, line by line. Emotion words (defined below) were extracted from the text and entered onto digital datasheets. In each case, the names of the involved characters, their gender and societal rank, the speaker, and any consequences were noted. This was done to enable the plotting of each of these variables against any of the others to uncover possible correlations and narrative and linguistic patterns to extract statistical information. Each entry was verified, and the list was refined using electronic versions and the database Mörkuð íslensk málheild. The words in the lexicon were then categorized into prominent categories, significant themes, and narrative formulas for further analysis. The process involved disparate obstacles and considerations, which are described in the following sections.

\subsection{Selection of words}

The selection of the words posed several challenges. First, there is the question of what qualifies as a word that refers to an emotion. The chosen method is based on a simple linguistic test developed by Clore, Ortony, and Foss (1987), which has been used in the semantic analysis of emotion words in psychological research (Johnson-Laird and Oatley 1989). To differentiate between emotional and non-emotional terms, the test distinguishes between two different contexts. One is the context of feeling something, and the other is being something. Thus, "angry" is categorized as a genuine emotion term because the subjects of the above study rated both "feeling angry" and "being angry" as emotions. However, "abandoned" is not an emotion term because "feeling abandoned" is rated as an emotion, whereas "being abandoned" is not. This test was used as a basic reference point when collecting words from the text. Compound

and Eiríkur Jónsson, where Reykjabók (AM 468 4to), dated to 1300-1325, is the base manuscript, with minor emendations from the Íslenzk fornrit edition, which is based on mid-fourteenth century Möðruvallabók (AM 132 fol.). In the case of Egils saga, this edition is based on Finnur Jónsson's 1886-88 edition of the saga, with minor emendations and supplements from Bjarni Einarsson. These, and the Íslenzk fornrit edition of Egils saga, all have Möðruvallabók as the base manuscript. Each entry in the lexicon was subsequently verified in the Íslenzk fornrit editions of the sagas, and the few deviations that occur are noted in footnotes. However, the poetry of Njáls saga in the Íslenzk fornrit edition that is not included in the Svart á hvítu edition is included in this study. Other editions and manuscripts were not systematically searched but were consulted for comparison in individual cases, and these instances are noted in the footnotes. 
words were added to this that include an emotion word as well as short phrases and idioms that refer to an emotional state.

However, the general concept of "emotion words" admittedly has a fuzzy boundary, and the process is far from absolute. There are words that hover on the border of any definition of emotions, such as the more than two hundred instances of góðr 'good' that appear in the sagas. Góðr can semantically refer to "being kind" in addition to "the good quality" of something. On further analysis, in most cases in the two sagas, gódr proved to refer to an act or a quality but not to a feeling of kindness. However, this is unclear in some cases or even unintelligible from the text. Given the circumstances, góðr is not included in the lexicon.

More, but less frequent, words have an ambivalent meaning, where the context and placement of the word in the text in each case had to be considered to determine whether it denotes an expression of emotion. For example, angr is an emotion word denoting sadness in the translated romance Parcevals saga, as Larrington (2015: 85) has discussed. She transfers this meaning to the same word in Njáls saga (87). However, in the context in which it appears in Njáls saga (1954: 457), angr denotes "material damage", "trouble", or "harm" done to someone, rather than sad feelings. ${ }^{5}$ Thus, it is not included in this lexicon. Another example is the verb hressa and its reflexive form hressask, which can mean both "to cheer up" and "to recover one's strength". For this word, the lexicons only count the occurrences that clearly and evidently refer to the former meaning because that sense refers to emotions, but the other does not.

Second, the fact that the textual material is from a distant culture and written in a foreign language must be considered. As has been demonstrated in numerous ethnographic and linguistic studies, emotion concepts and emotion categories vary across time periods, languages, and cultures. A semantic comparison across languages and cultures can prove highly precarious (Wierzbicka 1999: 24-31; Goddard and Wierzbicka 2014: 8-10; Russell 1991: 429-33) and invites the risk of an anachronistic bias, resulting in words and terms being overlooked or that meaning is transferred onto them that they do not impart. An emotion word in one language sometimes does not even exist in others. For example, the German word Schadenfreude, 'delight in another person's misfortune', has no equivalent in English. This same view applies when studying past

\footnotetext{
${ }^{5}$ See Einar Ól. Sveinsson's commentary in Brennu-Njáls saga (1954: 457) and "angur" in Íslensk orðabók (Mörður Árnason 2007).
} 
cultures and languages. As Shweder and others emphasize, the goal is to "render the meaning of other people's mental states without assimilating them in misleading ways to an a priori set of lexical items available in the language of the researcher." (Shweder et al. 2008: 424).

A case in point is vinátta "friendship'. In the modern sense, "friendship" and the Modern Icelandic corresponding term vinátta would be viewed as a word expressing feelings of affection. In Njáls saga and Egils saga, however, vinátta and vinr 'friend' most often refer to political alliances and practical social bonds - not to an internal state of feelings of affection. ${ }^{6}$ Thus, it is often discussed in relation to forming an alliance, such as with a king in Egils saga: "Segðu svá konungi, at ek mun vera vinr hans" (Egils saga 1933: 13), 'Tell the King that I will be his friend', and in Njáls saga, when Gizurr pleads to Gunnarr to form an alliance with Otkell by requesting: "pess beiðu vér, at pú sér vinr Otkels" (ВrennuNjáls saga 1954: 132), 'We ask that you become a friend to Otkell'. Here, Gizurr is far from suggesting that Otkell and Gunnarr become affectionate confidants but is suggesting that they form a practical alliance where Otkell could count on Gunnarr's political support. As Jón Viðar Sigurðsson demonstrates in his analysis of friendship in Iceland c. 900-1300: "friendship ties might best be compared to a contract between two parties with clear reciprocal obligations. Feelings often had little to do with it." (Jón Viðar Sigurðsson 2017: 3). The vast majority of the occurrences of the words vinr, vinátta, and vinfengi in the two sagas clearly refer to such a "contract", although it admittedly remains ambiguous in odd cases if affection is perhaps additionally being alluded to. These words are thus not included in the lexicon. However, the word ástvinátta 'affectionate friendship' is included owing to the prefix ást- (Egils saga 1933: 284), which clearly denotes affectionate feelings. Furthermore, it is sometimes noted that vinátta 'friendship' is karr 'dear' (Egils saga 1933: 3; BrennuNjáls saga 1954: 168); and the word karr is included in the lexicon.

"Shame", in particular, is discussed here because honour is a prominent theme in the genre of Íslendingasögur. However, the Modern English word "shame" emerges as a very problematic term to assimilate directly to other cultures (Shweder et al. 2008: 418-20; Russell 1991: 430-31). Skoqmm is one of the words Larrington classifies as an emotion word and translates it

\footnotetext{
${ }^{6}$ See examples of vinátta 'friendship' in Egils saga $(1933: 13,88,214)$ and in Brennu-Njáls saga (1954: 122, 168, 200), and of vinr 'friend' in Egils saga $(1933: 15,20)$ and in BrennuNjáls saga (1954: 12, 132, 286).
} 
to English as "shame" (Larrington 2015: 87-88). This particular English word is defined in the Oxford English Dictionary $(O E D)$ as a "painful emotion arising from the consciousness of something dishonouring, ridiculous, or indecorous in one's own conduct or circumstances". A different, non-emotional definition of "shame" is also offered: a "loss of esteem or reputation". Skomm has both these meanings in Old Norse and Modern Icelandic, although the latter meaning is more common. ${ }^{7}$ Skomm and related words, as well as the antonym sæm 'honour', are certainly frequent in Njáls saga, where honour and humiliation are prominent themes. ${ }^{8}$

However, it can be argued that skomm, as it appears in Njáls saga, does not refer to an inner state of feeling shame or being ashamed. Rather, it refers to a social context: by behaving in a certain way, the characters can suffer a loss of status and reputation or are at the risk of suffering dishonour in the eyes of others. The meaning in this context does not include the person feeling shame. This is the case in all instances of the word in Njáls saga.

Two examples will be taken here to illustrate this point. First, Rannveig's famous words to her daughter-in-law, Hallgerðr: "Illa ferr pér, ok mun pín skọmm lengi uppi.” (Brennu-Njáls saga 1954: 189), 'Your actions are wicked, and your dishonour will be long-lasting'. This does not mean that Hallgerðr will feel shameful for a long time. "Lengi uppi" refers to something being remembered by the public for a long time. Therefore, the sense is that Hallgerðr will be regarded as dishonourable in the eyes of others for a long time, but the saga is silent about Hallgerðr's emotions in this scene. Another representative example is from Gunnarr's final battle, when he picks up his enemies' arrow and shoots it back at them and says: "er peim pat skǫmm, ef peir fá geig af vápnum sínum" (187), 'it is a disgrace for them, if they are harmed by their own weapons'. Gunnarr is commenting here on how ignominious it would appear for his opponents to be hurt by their own weapons. Whether his enemies will feel any shame or self-loathing is not indicated, only that this would result in other members of society thinking less of them. Furthermore,

\footnotetext{
${ }^{7}$ See the 180 examples in the database Ordbog over det norrøne prosasprog. For different meanings in Modern Icelandic, see "skömm" in Íslensk orðabók (Mörður Árnason 2007). ${ }^{8}$ The word appears thirteen times in Brennu-Njáls saga (1954) in the genitive (skammar) on 114, 345, and on 417 in the combination skammarvíg. Nominative and accusative forms (skomm) appear on 137, 149, 187, 189, 315, 330, 372 (twice) and 402. This corresponds to the Svart á hvítu edition, which adds one more case of skomm on 269, included here because that edition is the basis of this lexicon.
} 
this sense of the word skomm seems to apply to all ten cases of skomm's synonyms in Njáls saga. ${ }^{9}$ The same applies to Egils saga. Skoqmm is thus not included in this lexicon, nor are words from the same category, such as svivirðing, sneypa, and óvirðing. However, this does not mean that the feeling of skomm is not expressed in the sagas through other modes, such as action and various verbal means that denote the feeling of shame and humiliation (see Miller 1993: 116-130).

\subsection{Problems of categorization and the prototype approach}

To analyse and compare the size of the vocabulary for different emotions, the words need to be categorized. The question arises what emotion categories apply to Old Norse sagas? Modern psychologists, on the basis of recognition of emotions from facial expressions across cultures, have claimed that there is a set of universal basic emotions. Paul Ekman has argued that there are seven: ANGER, FEAR, SURPRISE, SADNESS, DISGUST, CONTEMPT, and HAPPINESS (Ekman 1994; Ekman and Cordaro 2011: 365-66). The basic emotional modes are only five according to Johnson-Laird and Oatley (1989: 90), who leave out Ekman's SURPRISE and CONTEMPT. Carrol Izard's fundamental emotions number ten, among them are INTEREST and GUILT, which are not on the other lists (1977: 85-92).

However, the concept of basic emotion is not useful as means of determining lexicographical categories when it comes to literary works from a distant culture. Irrespective of how universal or basic some emotions might be, an abundance of ethnographic and linguistic evidence demonstrates that emotions are defined and categorized in different ways across languages and cultures (Wierzbicka 1986: 585-87; Russell and Lemay 2000: 496; Shweder et al. 2008: 424). How (basic or not) emotions are described, expressed, termed, and categorized in different communities is culturally relative. Lists of emotions and categories of emotion have been made from ancient times by Aristotle, Plato, Cicero, Aquinas, and others, which Barbara Rosenwein (2008) and Simo Knuuttila (2004) provide a good summary of, and they are all different. This illustrates that, for the present purpose, it is misleading at best to apply previously set categories from a different culture using a different language to the lexis here.

\footnotetext{
${ }^{9}$ Synonyms appear ten times, svívirðing on 28 and twice on 226; svívirða 341; svívirðiligr (adj.) 372, 432 and additionally on 139 in the Svart á hvítu edition, but the same place in the Îslenzk fornrit edition reads skǫmm (36). Sneypa appears on 130, 306; óvirðing 371.
} 
Considering the above, it would be most useful to assess the emotion words in the sagas in relation to the prototype approach, which is a framework used to conceptualize people's knowledge on emotions in psychological research. ${ }^{10}$ The approach entails the conceptualization of people's knowledge of emotions as organized around prototypes in a graded structure, similar to a colour spectrum. Emotion words form clusters or groups around the prototypes, and further, the words and groups are organized within a hierarchy from abstract to concrete, such as POSITIVE EMOTIONS $>$ LOVE $>$ AFFECTION $>$ ENDEARMENT. This framework assumes a necessary fluidity and some degree of overlap between categories with a flexibility that makes it particularly useful in its application for the present purpose. Based on this, presupposed categories were not used to categorize the words in the two lexicons in this study. Instead, clusters were formed by gradually grouping words together and considering them one by one based on the similarity of their meaning. The categories do not refer to the idea of basic emotions but to the broad themes emerging from the grouping of the words according to their meaning. When the emotion categories had been identified (ten for Njáls saga and nine for Egils saga), the words were organized in a hierarchy with overarching categories and subordinate categories.

The method forms a layered structure where the emotion words within each domain group reflect finer gradations of their head category, and their similarity can be a matter of degree. For example, the words allreiðr 'very angry' and styggr 'morose, irritated' both belong to the ANGER category of Egils saga, but the former denotes a much more intense form of the feeling of anger than the latter. Two categories of POSITIVE and NEGATIVE emotions are at the superordinate level of each lexicon. The middle level forms the positive categories of JOY, LOVE, COURAGE, and TRANQUILLITY, and the negative categories of ANGER, FEAR, SADNESS, and CONTEMPT and the category SURPRISE, which includes (in Njáls saga) both negative and neutral words. Where applicable, opposing categories of feelings are paired in Tables 1 and 2 below. The negative category of ENVY additionally emerged from Njáls saga. Some of the mid-level categories (FEAR, COURAGE, and LOVE) are divided into subcategories, but not completely identically for both sagas, as the lexicon for Njáls saga includes two subcategories

\footnotetext{
${ }^{10}$ Pioneering work on the prototype approach is by Eleanor Rosch (1978). On the application of the probabilistic/prototype approach, see Niedenthal (2008: 592-93); Russell and Lemay (2000: 494-95).
} 
Tab. 1. Words referring to an emotional state in Egils saga. Numbers following each heading refer to how many words are in the category. Numbers in parenthesis refer to the frequency. The absence of a number indicates the word occurs only once.

\begin{tabular}{|c|c|c|c|}
\hline Egils saga, negative & & Egils saga, positive & \\
\hline SADNESS 8 (22) & & JOY $18(41)$ & \\
\hline allókátr, adj. & 'very unhappy, sad' & allfeginn, adj. & 'very glad, joyful' \\
\hline harma, v. & 'mourn' & allfeginsamliga, adv. & ‘very joyfully’ \\
\hline harmdauði, adj. & 'mourned' & allglaðr, adj. & 'very glad' \\
\hline harmr, n. (8) & 'grief' & allkátr, adj. (8) & 'very cheerful, happy' \\
\hline hryggr, adj. & 'sad, grieved' & einteiti, adj. & 'in very good spirits' \\
\hline ógleði, n. (5) & 'unhappiness, sadness' & feginn, adj. (5) & 'glad, joyful' \\
\hline ókátr, adj. (4) & 'unhappy, sad' & feginsamliga, adv. (5) & ‘joyfully’ \\
\hline \multirow[t]{11}{*}{ sorg, n. } & 'grief, sorrow' & glaða, v. & 'gladden' \\
\hline & & glaðr, adj. & 'glad' \\
\hline & & gleði, n. (3) & 'gladness, merriment' \\
\hline & & gleðimaðr, n. (2) & 'a cheery man' \\
\hline & & gleðja, v. (3) & 'gladden, enliven' \\
\hline & & glýjaðr, adj. & 'gleeful, cheerful' \\
\hline & & hressa, v. (3) & 'cheer up' \\
\hline & & í góðu (adj.) skapi & 'in good spirits’ \\
\hline & & kátr, adj. (2) & 'cheerful, happy’ \\
\hline & & léttr, adj. & 'cheerful' \\
\hline & & óhryggr, adj. & lit.: 'un-grieved' \\
\hline FEAR 9 (14) & & COURAGE 10 (21) & \\
\hline - Fear & & - Bravery & \\
\hline hræðask, v. (3) & 'be afraid of, fear' & fullhugi, n. & 'man without fear' \\
\hline hræðslugœði, n. & 'fear, actions from fear' & hafa (v.) hug & 'have courage' \\
\hline óask, v. & 'dread, fear' & herða (v.) huginn & 'gather one's courage' \\
\hline óttask, v. (3) & 'fear' & hugaðr, adj. & 'courageous' \\
\hline ótti, n. (2) & 'fear, dread' & ofrhugi, n. & 'bravery’ \\
\hline skelfa, n. & 'frighten' & óttalauss, adj. (2) & 'fearless' \\
\hline skelkr, n. & 'fear, fright' & pora, v. (6) & 'have courage' \\
\hline - Cowardice & & - Audacity & \\
\hline ódjarfr (adj.) & 'un-daring' & dirfð, n. (2) & 'daring, boldness' \\
\hline - Anxiety & & djarfliga, adv. (2) & 'daringly, boldly' \\
\hline hafa áhyggju (n.) & 'be anxious, worried' & djarfr, adj. (4) & ‘daring, audacious' \\
\hline ANGER 14 (37) & & TRANQUILLITY 4 (6) & \\
\hline allófrýnn, adj. & 'very sullen, resentful' & hógværr, adj. & 'gentle, meek of mind' \\
\hline allreiðr, adj. (3) & ‘very angry' & kyrrlátr, adj. (2) & 'calm, gentle' \\
\hline heipt, n. (2) & 'fury, spiteful anger' & stilliliga, adv. (2) & 'calmly, composedly' \\
\hline heiptugligr, adj. & 'spiteful, virulent' & stilltr, adj. & 'tempered, composed' \\
\hline
\end{tabular}




\begin{tabular}{|c|c|c|c|}
\hline \multicolumn{2}{|l|}{ Egils saga, negative } & \multicolumn{2}{|l|}{ Egils saga, positive } \\
\hline óblíðr, adj. & 'harsh', lit.: 'un-gentle' & & \\
\hline ófrýnn, adj. & $\begin{array}{l}\text { 'sullen, resentful, } \\
\text { morose' }\end{array}$ & & \\
\hline reiðask, v. (2) & 'become angry' & & \\
\hline reiði,n. (6) & 'anger' & & \\
\hline reiðinn, adj. & 'quick to anger' & & \\
\hline reiðr, adj. (12) & ‘angry' & & \\
\hline snellt, adv. & 'angrily' & & \\
\hline styggliga, adv. & 'angrily, harshly' & & \\
\hline styggr, adj. (4) & 'morose, irritated' & & \\
\hline pykkja, n. & 'anger, resentment' & & \\
\hline CONTEMPT 8 (10) & & LOVE $15(41)$ & \\
\hline allpungr (adj.) til & $\begin{array}{l}\text { 'very unfriendly of } \\
\text { mind' }\end{array}$ & - Love & \\
\hline fátt (adj.) [um] með (2) & 'a strained relationship' & allkærr, adj. (2) & 'very dear, beloved' \\
\hline fjándskapr, n. & 'hostility' & ást, n. & 'love' \\
\hline fjón, n. & 'hostility, hatred' & ástúðigr, adj. & 'loving' \\
\hline $\begin{array}{l}\text { hafa (v.) pungan hug } \\
\text { á (2) }\end{array}$ & 'unfriendly of mind' & ástvinátta, n. & 'intimate friendship' \\
\hline hatask (v.) við & 'hostile towards' & ástvinr, n. & 'beloved, dear friend' \\
\hline úlfúð, n. & 'hostility, enmity' & ávarðr, adj. & 'dear, beloved' \\
\hline \multirow[t]{5}{*}{ vera allilla (adv.) til } & $\begin{array}{l}\text { 'have much antipathy } \\
\text { or dislike' }\end{array}$ & elska, n. & 'love' \\
\hline & & elskr [at], adj. (2) & 'love, be fond of' \\
\hline & & kærleikr, n. (11) & 'love, intimacy' \\
\hline & & kærr, adj. (8) & 'dear, beloved' \\
\hline & & unna, v. (7) & 'love' \\
\hline SURPRISE 1 (3) & & - Affection & \\
\hline \multirow[t]{4}{*}{ undra, v. $(3)^{a}$} & 'wonder' & blíða, n. (2) & 'gentleness, affection' \\
\hline & & blíor, adj. & 'gentle, affectionate' \\
\hline & & blíðskapr, n. & $\begin{array}{l}\text { 'affection, friendly } \\
\text { terms' }\end{array}$ \\
\hline & & finnask (v.) mikit um & 'admire, be fond of' \\
\hline
\end{tabular}

Note

${ }^{a}$ Neither negative nor positive.

beyond that of Egils saga. Overall, this provided 445 instances in which an emotion word is uttered: 250 from Njáls saga and 195 from Egils saga. Seventy-nine different emotion words were extracted from Njáls saga, and eighty-seven were taken from Egils saga. 


\section{Analysis of the lexicon: Egils saga}

Compared to Icelandic novels of the nineteenth and twentieth centuries, the vocabulary of Íslendingasögur is small - the whole corpus of over thirty sagas contains only about twelve thousand and four hundred different headwords, or lexemes, in total (Sverrir Tómasson and Örnólfur Thorsson 1991: 505). ${ }^{11}$ This seems to reflect their "characteristically laconic and economic style" (Pórir Óskarsson 2005: 365). Egils saga is just over sixty-two thousand words long, but the number of individual lexemes is just roughly twenty-eight hundred (Sverrir Tómasson and Örnólfur Thorsson 1991: 504). The eighty-seven emotion words, which are listed in Table 1, form $3.1 \%$ of the sagas' vocabulary. The total count of emotion words in Egils saga (195) is $0.31 \%$ of the total word count in the saga. The words are spread in nine emotion categories: the NEGATIVE categories of SADNESS, FEAR, ANGER, and CONTEMPT; the POSITIVE categories of JOY, COURAGE, TRANQUILLITY, and LOVE; and SURPRISE which includes only a neutral word. Each category (except SURPRISE, which has only one word) includes different nuances of meanings. Fourteen of the eightyseven emotion words only occur in poetry. ${ }^{12}$ In all, in Egils saga, more words communicate positive rather than negative emotions in the ratio of three to two. The biggest categories are LOVE and JOY. In close to half of the cases (42\%) in which an emotion word is uttered in Egils saga, it connotes the positive feelings of either LOVE or JOY. Next comes ANGER, but these three categories are the biggest and are quite similar in size.

\subsection{Royal anger}

One would not characterize Egils saga as having especially joyous or loving themes, as its most prominent categories of emotion words suggest. By examining the most frequent words in the categories of JOY and LOVE, it emerges that, in many instances, the words refer to the emotions of royals and announce their temper, such as their fondness or dislike of

\footnotetext{
${ }^{11}$ Lexemes are the minimal units that form a lexicon. They are the headwords found listed in a dictionary. One lexeme can include different inflections that belong to the same syntactic category.

12 ávarðr 'dear', fjón 'hatred', glaða 'gladden', glaðr 'glad', glýjaðr 'cheerful', heipt 'fury', heiptugligr 'spiteful' or 'virulent', hugaðr 'courageous', óask 'dread' or 'fear', ofrhugi 'bravery', óhryggr 'un-sad', skelfa 'frighten', sorg 'sorrow', and pykkja 'anger' or 'angry resentment'.
} 
their subjects' actions and loyalty. Therefore, many sentences of this type appear:

var konungr allkátr (30)

konungr gladdisk pá (35)

í miklum kærleik við konung (177)

konungr hefir mikla elsku á pér (199) 'the King has much affection for you' 'the King was in very good spirits'

'the King became glad'

'very intimate with the King'

This is also true for the ANGER category, where more than half of the occurrences refer to the king's anger (twenty occurrences out of thirtyseven). The element of the saga that deals with the relationship of Egill and his kin with Norwegian royalty seems to contribute to the number of instances of these emotion word categories..$^{13}$ Ira regis, or royal anger, is a specific display of anger tied to kings, queens, and other royals in the literature and the learned writings of the medieval West (Althoff 1998; White 1998; Barton 1998). In these writings, the king's expression of his anger is portrayed as primarily demonstrative, functioning as a strategic ruling device. As Stephen White argues (1998: 142-43), this involves the king publicly displaying joy and anger alternately, controlling his subjects by giving illustrative signals of his moods. As such, it forms a part of the king's "technology of power" (White 1998: 151).

The demonstration of the king's emotions on these occasions was encoded in "scripts and schemas" that were incorporated into political processes; "it was part of an entire discourse of feuding or retaliatory disputing" (White 1998: 146). Therefore, the expression of just and righteous royal anger was strategic; a ruling practice as well as an illustration of the sovereignty of the king (Barton 1998: 158). Such royal anger appears to be prominent in Egils saga. In more than half of the cases in the ANGER category, the words refer to a king or jarl displaying his anger at certain actions of his subjects, such as the following examples:

konungr var reiðr $(13,29,34)$

bað konung vera eigi reiðan (13) 'the King was angry'

'asked the King not to be angry'

\footnotetext{
${ }^{13}$ Indeed, Egils saga has stylistically much in common with the Old Norse genre of konungasögur (kings' sagas), see, e.g., Ármann Jakobsson (2002); Haukur Porgeirsson (2018).
} 
varð [Eiríkr konungr] reiðr mjǫk (160)

Allreiðr var konungr nú (182)

hafði hann ok fengit reiði konungs (71)

Konungr varð við styggr (13)

varð fyrir reiði Bjarnar Svíakonungs

(182)
'[King Eiríkr] became very angry'

'the King was now very angry'

'he had suffered the King's anger'

'the King fell into a bad temper'

'suffered the anger of Bjorn, King of Swedes'

A representative example is the following account in Egils saga that tells of the disputes between Pórólfr Kveld-Úlfsson and King Haraldr lúfa of Norway in Chapters 11-22. These chapters tell of how the sons of Hildiríðr surely and steadily succeed in defaming Pórólfr to the King and convince him that Pórólfr aspires to surpass him and perhaps overthrow him. In the beginning, Pórólfr is close to King Haraldr, who has given Pórólfr the title of a landholder (24). However, the King becomes angry when Pórólfr surpasses him in the number of followers at a feast. The King's displeasure at this is displayed by him becoming "ókátr" (29) 'cheerless' and he turns red, falls silent, and men could feel that he was angry (29). Pórólfr soothes the King with appeasing talk and the gift of a great ship. The King's mood turns mild and cheerful at this (29). Next, it is noted that King Haraldr sits in very good spirits (30) at a feast. There, the sons of Hildiríor tell him that Pórólfr plans to betray him. The King "reiddisk mjok" (32), 'became very angry', but he simultaneously is pleased with the gifts that the sons of Hildirior brought him. But at the mention of Pórólfr's name, the King demonstrates his anger so that he "svarar engu, ok sáu menn, at hann var reiðr” (34), 'answers nothing, and people could see that he was angry'. Pórólfr counteracts by giving him beaver skins and other treasures, and the King's mood turns, he becomes glad and is willing to listen to Pórólfr's point of view (35). Nevertheless, Pórólfr is defamed again, and King Haraldr becomes "inn reiðasti” (38), 'most angry', yet again. Pórólfr consults with his friends, and they discuss how the King's mood might be turning (38). Subsequently, Pórólfr attempts to appease Haraldr with gifts and reassurance but to no avail. Haraldr demands full surrender, which Pórólfr is not willing to provide. The affair concludes with Haraldr slaying Pórólfr in battle (54).

Throughout the whole account, the swinging mood of King Haraldr is central, and it is carefully noted what actions arouse his anger and how 
his subjects try to appease it. The King's anger has a clear demonstrative feature: it is displayed vividly in public by reddening and not speaking, and it is noted in the text that the men could see that the King was angry. In these scenes, King Haraldr alternates in a script-like way between displaying anger and joy as a strategic ruling device as fits his political aim of controlling his subjects and maintaining his power. Similar examples of royal anger appear throughout Egils saga. This narrative device results in the prominence of words connoting anger, joy, and love in the saga's lexicon of emotion words; most cases are tied to this element of strategic royal "technology of power" (White 1998: 151).

\subsection{Formulas}

It is thus evident that the frequent appearance of words denoting anger in Egils saga are part of a narrative formula involving royal anger. Íslendingasögur are characterized by many formulaic locutions when people and events are described, and indeed formulas have been noted as "a typical feature of saga style" (Sävborg 2017: 115). Many repeated scenes and situations have their own particular formula. Thus, in the corpus, concerning how characters are introduced, well over one hundred examples exist of men entering the saga described as miklir ok sterkir 'great and strong' (Sverrir Tómasson and Örnólfur Thorsson 1991: 505$6)$.

Such formulas are narrative constructions that signal to the audience how to understand what they read or hear. Thus, as Daniel Sävborg argues, they function by "arousing the expectation of the audience or reader", and they "are loaded with meaning necessary for the interpretation of the events, characters, and plot" (Sävborg 2017: 118). For example, Sävborg identifies repeated formulas that express amorous feelings through behaviour, such as when a man and a woman sit and converse, visit frequently and give gifts (Sävborg 2007: 45-67).

In Egils saga, $76 \%$ of the emotion words in the lexicon above are only used once or twice. The other $24 \%$ that are used more often are frequently a part of a formula, such as is applied in the case of royal anger. Another example is how almost exclusively and repeatedly the words feginn 'glad, joyful', allfeginn 'very joyful', feginsamliga 'gladly' or 'joyfully', and allfeginsamliga 'very joyfully' are used when someone is received upon return from somewhere, in sentences of this type: 
$\begin{array}{ll}\text { Tók hann við peim allfeginsamliga (19) } & \text { 'he received them very joyfully' } \\ \text { tók hann við honum feginsamliga (81) } & \text { 'he received him joyfully' } \\ \text { tók hann feginsamlega við peim (92) } & \text { 'he received them joyfully' } \\ \text { tekit við honum vel ok feginsamliga (174) } & \text { 'received him well and joyfully' } \\ \text { tók Pórir feginsamliga við konungssyni } & \text { 'Pórir received the King's son } \\ \text { (166) } & \text { joyfully' }\end{array}$

The same applies to the formula of men repeatedly being allkátir 'very joyful' when feasting and drinking (Egils saga 1933: 115-16, 121, 125) and being in karleikar 'affection' or 'intimacy' when describing a good, secure relationship with a royal:

komsk hann í ina mestu kærleika við konung (10)

'he became very intimate with the King'

í allmiklum kærleikum af konungi (20)

'very intimate with the King'

skilðusk pá með kærleik miklum (29) 'they departed with much intimacy'

í miklum kærleik við konunginn (177)

'in much intimacy with the King'

Pórir var pá í inum mestum kærleikum við konung (90)

'Pórir was then in the most intimacy with the King'

The other part - the $76 \%$ of the lexicon only used once or twice - are words applied in a specific context in a purposeful, precise way. A good example of how this is done is in relation to Egill's son, Porsteinn, who is at the centre of the saga in the last ten chapters. Porsteinn is baptized as a Christian when the new faith arrives in Iceland and builds a church at Borg (Egils saga 1933: 299) whereas Egill remains a heathen his whole life. ${ }^{14}$ Egill has grown old and decrepit and can be seen as representing the past ways at this point in the saga, a pagan culture that is in many ways coming to an end. This is underlined by emphasizing Porsteinn as Egill's successor in the last chapters of the saga and how different the two are in their emotional character, as well as the contrast between the two strands of dark and bright appearance that run in the family. In most ways,

\footnotetext{
${ }^{14}$ At King Aðalsteinn's request, Egill gets primsignaðr (takes the sign of the cross) to be able to interact with Christians. Those who did so kept their faith and were not turning to Christianity (Egils saga 1933: 128-29).
} 
Porsteinn is the emotional antithesis of his father. The narrator describes Porsteinn as "órefjusamr ok réttlátr ok óáleitinn við menn" (Egils saga 1933: 293), 'un-deceitful, just and unobtrusive'. While the dark Egill is notorious for his extreme temper, all the emotion words in the category TRANQUILLITY refer to Porsteinn: hógvaerr 'gentle', kyrrlátr 'calm', stilltr 'tempered', and stilliliga 'composedly' $(274,277,274)$. In addition to being blond, beautiful, wise, and strong (274), Porsteinn's disposition can be illustrated with reference to what Bandlien has described as the Christian ideal of "rational, tempered and civilized" masculinity (Bandlien 2005: 164), whereas Egill rather conforms to the Old Norse "aggressive masculine ethic" (Meulengracht Sørensen 1983: 21). The differences in the choice of words used to describe the emotions of the father Egill and his son Porsteinn reflect how specifically the emotion words are applied in the saga, a point further illustrated in other themes, such as gender and poetic language, to which I turn next.

\subsection{Gender differences and Ásgerðr Bjơrnsdóttir}

Egils saga is almost void of emotion words about women's feelings. A woman's emotion is only mentioned eleven times in the saga out of the 195 occurrences. Five of those cases concern Queen Gunnhildr's royal feelings of like or dislike ${ }^{15}$ and can be viewed in the same light as the examples above on royal anger. Porgerðr's feelings are noted once from the mouth of her father Egill: "mikla ást hefir pú sýnt við mik" (244-45), 'you have demonstrated much love towards me', and three examples concern minor female characters that briefly enter the saga: djarfr, ókátr, feginn $(85,201,230)$ 'daring, unhappy, joyful'. Lastly, the feelings of Ásgerðr Bjǫrnsdóttir are noted twice with the words ókátr and unna (148, 274) 'unhappy, love'. The latter concerns the occasion during which it is noted that much love exists between her and her son Porsteinn, whereas Egill does not love his son much: "Egill unni honum lítit; Porsteinn var ok ekki við hann ástúðigr, en pau Ásgerðr ok Porsteinn unnusk mikit.” (274), 'Egill loved him little; Porsteinn was likewise not loving towards him, but Ásgerðr and Porsteinn loved each other very much'.

This is the only example from the saga where so many emotion words (three) are found in the same sentence. Yet, this brief account is a fine

\footnotetext{
${ }^{15}$ These are karleikr 'intimacy', Egils saga 1933: 94; karr 'dear', 106, 123, 152; allpungr til 'very unfriendly of mind towards', 150.
} 
example of the emotive style of the saga. In just a handful of words, a tense and dramatic family situation is laid out, where the cold contempt between father and son is contrasted with much love and affection between the son and his mother. The scene also reverberates the strained relationship between Egill and his own father, Skalla-Grímr, who tried to kill him as a child and subsequently did not speak to him for a whole winter (101-2). ${ }^{16}$

The other time that Ásgerðr's feelings are noted is when Egill tells her that his brother Pórólfr, her husband, is dead. Egill has probably loved Ásgerðr since they were adolescents, ${ }^{17}$ and he now offers her his care, perhaps insinuating or suggesting that they marry. Her response is very obscure: “Ásgerðr varð mjokk ókát við pá soggu, en svaraði vel rœðum Egils ok tók lítit af ollu" (148), "Ásgerðr became very unhappy at hearing this, she answered Egill's words politely but gave little and indefinite answers.' Egill reacts to her moot response by falling into a deep melancholy and lastly confides in his best friend Arinbjorn how much he loves her. As the object of Egill's love, Ásgerðr is one of the central figures in the saga, and Egill's strong feelings towards her have decisive effects on how the narrative unfolds (see, e.g., Torfi $\mathrm{H}$. Tulinius 2004: 50-51). How Ásgerðr feels about him, however, remains rather hidden. When Egill finally gathers the courage to ask her to marry him, she does not disclose her will but simply dutifully refers the matter twice to her father and uncle to decide (150). The matter is finally concluded by Egill betrothing Ásgerðr. The fact that Ásgerðr does not express approval when repeatedly given the chance can be taken to indicate that she is not too keen on marrying Egill, but she does not assert opposition to it either, although her moot responses might consist of a statement thereof. Within the narrative, Ásgerðr's figure functions as the focus of Egill's desire, but she is, herself, almost invisible. She does not have an opinion or a voice. She is never given direct speech in the entire saga, and her feelings are implied only in relation to Egill's reactions to them. In this sense, she plays a narrative role similar to that of many idealized ladies in the courtly romances: her persona exists only in the form of a passive object of Egill's desire.

\footnotetext{
${ }^{16}$ Ármann Jakobsson (2008) writes about the tense relationship between Egill and his father.

${ }^{17}$ On the early onset of Egill's love for Ásgerðr, see Torfi H. Tulinius (2004: 50-51); Bredsdorff (2001: 23-34).
} 


\subsection{The speaker and the poetic voice}

The speaker of the emotion words in Egils saga is most often the narrator, or in two-thirds of the cases. Most frequently, the narrator is noting the feelings of royals (forty-two instances) or Egill (twenty-eight instances). As has been pointed out, the external focalization of the narrative voice in the genre of Íslendingasögur means that the characters' inner emotional processes are rarely analysed in the prose (Sävborg 2017: 123; Sif Rikhardsdottir 2017: 57; Miller 1992: 94-97). It should nevertheless be observed that multiple examples in this lexicon exist where the narrator does have access to the inner lives of the characters and communicates how they feel, as the following samples demonstrate:

\begin{tabular}{|c|c|}
\hline Kveld-Úlfr [varð] hryggr (60) & 'Kveld-Úlfr [...] became mournful' \\
\hline herði [Egill] pá huginn (178) & '[Egill] then plucked up his courage' \\
\hline $\begin{array}{l}\text { Skalla-Grímr varð við pat allglaðr } \\
\text { (87) }\end{array}$ & $\begin{array}{l}\text { 'Skalla-Grímr became very glad at } \\
\text { that' }\end{array}$ \\
\hline gerðisk Egill pá enn einteiti (216) & 'Egill turned to a very good mood' \\
\hline $\begin{array}{l}\text { unni honum ok vel faðir ok móðir } \\
\text { (80) }\end{array}$ & $\begin{array}{l}\text { 'his father and mother loved him } \\
\text { much' }\end{array}$ \\
\hline Egill unni honum mikit (243) & 'Egill loved him much' \\
\hline $\begin{array}{l}\text { var Pórólfr allókátr ok svá Arinbjorn } \\
\text { (113) }\end{array}$ & $\begin{array}{l}\text { 'Pórólfr was very unhappy, as was } \\
\text { Arinbjǫrn' }\end{array}$ \\
\hline
\end{tabular}

Here, the narrator appears omniscient, describing in direct words how characters feel and telling the audience that they are angry, sad, mournful, striving for courage, glad, merry, or in love. However, the feelings are not analysed or commented on further. The instances are brief, quick, and usually contain only one emotion word, occasionally two, but only once contain three.

When emotion words are uttered by a character in Egils saga, it is most often not about the character's own feelings but about the feelings of others (in two-thirds of the cases). Representative examples include Egill's question to a young woman: "Hvat grætr pú, mær? Ek sé pik aldri káta" (201), 'What are you crying over, young girl? I never see you cheerful', and his words to his daughter: "mikla ást hefir pú sýnt við mik" (244-45), 'you have shown me much love'.

Out of the 195 instances in which an emotion word is uttered in the 
saga, only twenty-tree apply to characters expressing their own feelings. The data thus conform to the general finding that characters in Íslendingasögur "rarely express their emotions themselves" (Sävborg 2017: 118). In accordance with Egill's centrality in the saga, in eighteen of those twenty-three cases, it is Egill who is speaking about his own emotions. A clear difference exists here between the prose and the poetry. Egill's selfexpression of emotions mainly occurs in his poems. Out of the eighteen instances, fifteen occur in his poetry: $:^{18}$

\begin{tabular}{|c|c|c|}
\hline ástvinr, $\mathrm{n}$. & 'beloved' & Sonatorrek 7 (248) \\
\hline glaðr, adj. & 'glad' & Sonatorrek 25 (256) \\
\hline gleðja, v. & 'gladden' & Lausavísa 5 (82) \\
\hline harmr, n. (3) & 'grief' & Lausavisur 17, 20, $59(142,145,295)$ \\
\hline heipt, n. (2) & 'fury' & Lausavísur 31, $50(170,269)$ \\
\hline óhryggr, adj. & 'un-grieved' & Sonatorrek 25 (256) \\
\hline reiði, $\mathrm{n}$. & 'anger' & Lausavísa 14 (121) \\
\hline sorg, $\mathrm{n}$. & 'sorrow' & Lausavísa 24 (149) \\
\hline undra, v. & 'wonder' & Lausavísa 57 (293) \\
\hline pora, v. (2) & 'have courage' & Arinbjarnarkv. 6 (259), Lausavísa 23 (148 \\
\hline pykkja, n. & 'angry resentment' & Lausavísa $47(228)^{19}$ \\
\hline
\end{tabular}

Skaldic poetry in the sagas has been shown to convey feelings, such as love and grief, more openly and in a more detailed way than is done in the prose, and the speakers analyse and describe their own emotions to a higher degree than in the prose (Sävborg 2007: 275-76; Sif Rikhardsdottir 2017: 85-97). However, while a statistical analysis such as this one confirms that self-expression of feelings occurs to a higher degree within the poetry than the prose, the use of emotion words comprises only a very small part of the conveyance of feelings in the poetry. The kennings and

\footnotetext{
${ }^{18}$ The three instances from the prose are "Hver ván er, at ek muna lifa vilja við harm penna?" (254), 'How can I be expected to want to live with such grief?'; “Hræðumk ek bjorninn" (167), 'I am afraid of the bear'; "áhyggjur hefi ek miklar" (214), 'I have great worries'.

19 "pykkiar" in Möðruvallabók, "pickjo" in Ketilsbók (AM 462 4to), which supports the emendation to "bykkja" 'angry resentment' in Egils saga (1992: 181) which I consider most likely to be correct. However, it is amended to "pykkjumsk" in Egils saga (1933: 228), which gives the meaning "I regard".
} 
other kinds of circumlocutions in the poems attributed to Egill, metaphors, rhythm, poetic language, and emotive themes that sometimes run through a whole poem, such as Sonatorrek, as well as the interaction of the poem with the prose, all work to intensify the emotive force of what is being expressed. These forcefully convey feelings in an artistic manner outside the narrow semantic scope of emotion words.

\section{Analysis of the lexicon: Njáls saga ${ }^{20}$}

Njáls saga is about one hundred thousand words long, but the number of individual words or lexemes is just roughly thirty-one hundred (Svanhildur Óskarsdóttir 1991: xvi). Of these lexemes, 2.5\% (seventy-nine) are emotion words, shown below in Table 2. The total count of emotion words in Njáls saga (250) is $0.25 \%$ of the total word count in the saga. The biggest category is ANGER. Words connoting this feeling are mentioned in $22 \%$ of all instances in which an emotion is named in the saga. Next comes FEAR (19\% occurrence). Njáls saga also has categories that Egils saga does not have: ENVY and being TAKEN ABACK (a sub-category of SURPRISE). Both are from the overarching NEGATIVE category. Overall, more occurrences of words communicate negative emotions in Njáls saga, with the ratio of three to two.

\subsection{The speaker}

Turning first to the speakers of the words, the data show that emotion words coming from the mouth of a character are more frequent in Njáls saga than Egils saga, or in roughly half of the cases an emotion word is uttered in the saga (compared to one-third in Egils saga). In fact, Njáls saga contains double the proportion of direct speech compared to Egils saga, as Peter Hallberg (1966) has demonstrated, and also that Njáls saga has the highest percentage (at $41 \%$ of the text) of direct speech of all the longer sagas (Hallberg 1966: 130).

\footnotetext{
${ }^{20}$ The lexicon includes words from poetry not included in the main text of the Svart á hvítu or Íslenzk fornrit editions, but which is published in an appendix in the latter. These are four words, óttlauss 'fearless' (Brennu-Njáls saga 1954: 468), djarfr 'bold' (471), hrceðask 'be afraid of' (477), and reiðr 'angry' (479), all from stanzas included in either Reykjabók or Kálfalækjarbók (AM 133 fol.).
} 
Tab. 2. Words referring to an emotional state in Njáls saga. Numbers following each heading in the table refer to how many words are in the category. Numbers in parenthesis refer to the frequency. The absence of a number indicates the words occurs only once.

\begin{tabular}{|c|c|c|c|}
\hline Njáls saga, negative & & Njáls saga, positive & \\
\hline SADNESS 11 (21) & & JOY 9 (26) & \\
\hline dapr, adj. & 'sad' & allkátr, adj. & 'very cheerful, happy' \\
\hline harma, v. (3) & 'mourn' & feginn, adj. (13) & 'glad, joyful' \\
\hline harmdauði, adj. (3) & 'mourned' & glaðr, adj. (3) & 'glad' \\
\hline harmr, n. (3) & 'grief' & gleðja, v. & 'gladden, enliven' \\
\hline harmsǫk, n. (2) & 'cause of grief' & gleðibragð, n. & 'merry looking' \\
\hline hugsjúkr, adj. & $\begin{array}{l}\text { 'depressed', lit. 'mind- } \\
\text { sick' }\end{array}$ & hlœgja, v. (2) & 'exhilarate, cheer up' \\
\hline hǫrmuligr, adj. & 'tragic, sad' & kátligr, adj. & 'cheerful' \\
\hline skappungt, adj. (4) & 'of heavy mind' & kátr, adj. (3) & 'cheerful, happy’ \\
\hline syrgja, v. & 'mourn, grieve over' & léttr, adj. & 'cheerful' \\
\hline tregi, $\mathrm{n}$. & 'sorrow' & & \\
\hline pykkja (v.) fyrir & $\begin{array}{l}\text { 'saddened, regretful, } \\
\text { sorry' }\end{array}$ & & \\
\hline FEAR $14(48)$ & & COURAGE 8 (30) & \\
\hline - Fear & & - Bravery & \\
\hline felmta, v. & 'be afraid' & allóhræddr, adj. & 'very un-afraid' \\
\hline hræðask, v. (13) & 'be afraid of, fear' & hugaðr, adj. & 'courageous' \\
\hline hræddr, adj. (11) & 'afraid' & ofrhugi, n. (2) & 'fearless man' \\
\hline hræðsla, n. (3) & 'fear' & óttlauss, adj. & 'fearless' \\
\hline óttafullr, adj. (1) & 'full of fear' & pora, v. (20) & 'have courage' \\
\hline óttask, v. (2) & 'fear' & óhræddr, adj. (2) & 'un-afraid' \\
\hline ótti, n. (3) & 'fear, dread' & - Audacity & \\
\hline æðra, n. (2) & 'fear, despair' & djarfliga, adv. (2) & 'daringly, boldly' \\
\hline - Cowardice & & djarfr, adj. & 'bold, daring' \\
\hline argr, adj. & 'cowardly' & & \\
\hline blauðr, adj. (3) & 'cowardly' & & \\
\hline huglauss, adj. & 'cowardly' & & \\
\hline hugleysi, n. & 'cowardice' & & \\
\hline ragr, adj. (5) & 'cowardly, fainthearted' & & \\
\hline \multicolumn{4}{|l|}{ Anxiety } \\
\hline áhyggja, n. & ‘anxiety, worry' & & \\
\hline ANGER $12(54)$ & & TRANQUILLITY 5 (12) & \\
\hline allreiðr, adj. & 'very angry' & hógværr, adj. (2) & 'gentle, meek of mind' \\
\hline beiskr, adj. & $\begin{array}{l}\text { 'embittered, } \\
\text { acrimonious' }\end{array}$ & orðstillttr, adj. & 'moderate in words' \\
\hline bráđr, adj. & 'quick-tempered' & skapgóðr, adj. & 'good-tempered' \\
\hline
\end{tabular}




\begin{tabular}{|c|c|c|c|}
\hline Njáls saga, negative & & Njáls saga, positive & \\
\hline geisa, v. (2) & 'rage' & stilla (v.) sig & 'temper oneself' \\
\hline reiðask, v. (10) & 'become angry' & stilltr, adj. (7) & 'tempered, composed' \\
\hline reiði,n. (11) & 'anger' & & \\
\hline reiðr, adj. (22) & 'angry' & & \\
\hline síreiðr, adj. & 'always angry' & & \\
\hline skapbráđr, adj. & 'hot-tempered' & & \\
\hline styggr, adj. (2) & 'morose, irritated' & & \\
\hline vera (v.) mikit í skapi & 'be very upset' & & \\
\hline œði (n.) mikil & 'much rage, fury' & & \\
\hline CONTEMPT 6 (13) & & LOVE $9(30)$ & \\
\hline fáleikr, n. (3) & 'strained/cold relation' & - Love & \\
\hline mislíka, v. (2) & 'dislike, resent' & ást, n. (2) & 'love' \\
\hline ópokki, n. (3) & 'animosity, hostility' & elskr, adj. & 'love, be fond of' \\
\hline ópykkt, n. & $\begin{array}{l}\text { 'ill-will, dislike, } \\
\text { discord' }\end{array}$ & kærleikr, n. & 'love, intimacy' \\
\hline fátt (adj.) um með (3) & 'strained relationship' & kærr, adj. (2) & 'dear, beloved' \\
\hline \multirow[t]{2}{*}{ vera illa (adv.) til } & $\begin{array}{l}\text { 'have antipathy or } \\
\text { dislike' }\end{array}$ & unna, v. (10) & 'love' \\
\hline & & leggja (v.) hug á (3) & 'be in love with' \\
\hline ENVY $2(6)$ & & Affection & \\
\hline Qfunda, v. (5) & 'envy' & blíða, n. (2) & 'gentleness, affection' \\
\hline \multirow[t]{2}{*}{ ofundarmaðr, n. } & 'one who envies' & blíðliga, adv. (4) & 'affectionately, gently' \\
\hline & & blíðr, adj. (5) & 'gentle, affectionate' \\
\hline \multicolumn{4}{|l|}{ SURPRISE 3 (10) } \\
\hline \multicolumn{4}{|l|}{ - shocked/taken aback } \\
\hline bregða (v.) í brún (2) & 'shocked, taken aback' & & \\
\hline bregða (v.) við (6) & 'shocked, taken aback' & & \\
\hline \multicolumn{4}{|l|}{ - wonder ${ }^{\mathrm{a}}$} \\
\hline undra, v. (2) & 'wonder' & & \\
\hline
\end{tabular}

Note

${ }^{\mathrm{a}}$ Neither negative nor positive.

Even though emotion words are often spoken by the characters in Njáls saga, they are usually not referring to their own feelings but those of others. In only about one-third of the instances in which a character speaks an emotion word, it concerns his or her own inner state (forty-two instances, of which five occur in poetry). These are spoken by twenty different characters, most often Gunnarr and Skarpheðinn (six times each), communicating their own fearlessness or anger. 
However, the few cases of self-expression include famous and muchquoted sentences, such as Gunnar saying "mér pykkir meira fyrir en oðrum mǫnnum at vega menn" (Brennu-Njáls saga 1954: 139), "the slaying of men saddens me more than other men', and Njáll saying "ek unna meira Hǫskuldi en sonum mínum, ok er ek spurða at hann var veginn, pótti mér sløkkt it sœtasta ljós augna minna" (309), 'I loved Hoskuldr more than any of my sons, and when I learned that he had been slayed, I felt like the dearest light of my eyes had been put out'. In Njáll's emotive speech, there is a rare elaboration and reiteration of an emotional state: "pat er sannligt at segja, at svá fellr mér nær um trega, at mér pœtti betra at hafa látit tvá sonu mína ok væri Hǫskuldr á lífi” (281), "it is true that I am so deeply stricken by grief, that I would think it better to have lost two of my sons and Hǫskuldr was still alive'. Njáll's grief is dwelt on here more than is done in any scene found in the prose of Egils saga. As Vésteinn Ólason points out (1998: 114), such unrestrained emotional talk "is unusual and unquestionably reflects the influence of religious literature" on Njáls saga.

When it comes to the narrative voice, however, it does not analyse the characters' inner lives with words but, nevertheless, has access to their psyche as in the following representative examples:

Hon unni honum mikit ok mátti eigi stilla sik ok grét hástǫum. (48)

var brúðrin dọpr heldr. (22)

Gunnarr varð glaðr við pat. (77)

Hann oqundaði mjǫk Gunnar frá Hlíðarenda. (119)
'She loved him much and could not contain herself and cried loudly.'

'the bride was rather sad.'

'Gunnarr became glad at this.'

'He envied Gunnarr from Hlíðarendi much.'

Here, the narrator describes how characters feel in a direct way through emotional language. However, the feelings are not commented on further. The instances are brief, quick, and most often contain only one or two emotion words. In this way, the use of emotion words is similar to that in Egils saga, although with notable deviances concerning Njáll's speech.

\subsection{Gunnarr and the application of royal anger}

Njáls saga does not concern itself much with the interaction of its main characters with kings and other royalty. However, examples of royal anger appear in Chapter 88 of the saga, when Práinn Sigfússon hides an escaped 
offender aboard his ship. This is the only scene in the saga that includes instances of royal anger in line with those that are described above, occurring in Egils saga. The escapee, Hrappr, has burnt Jarl Hákon's temple to the ground and killed some of his men. The Jarl repeatedly boards Práinn's ship and searches for Hrappr, each time to no avail. In each instance, the Jarl displays his anger and, for example, becomes on one occasion "svá reiðr, at ekki mátti við hann mæla" (219), 'becomes so angry, that it was not possible to speak to him'. When Práinn flatly denies having hidden Hrappr aboard his ship, Hákon does not resort to violence but coldly notes: "heldr vil ek, at pú níðisk á mér en ek á pér." (220), 'I would rather have that you behave shamefully towards me than I towards you'. Thus, it is stressed in the scene that it is honourable for a noble man like Hákon to show restraint, while it is also made clear that his mere display of anger arouses fear in his subjects. But even though Jarl Hákon's noble anger is noted many times in this particular scene, no one's anger is mentioned more often in the saga than Gunnarr Hámundarson's, or in $21 \%$ of the cases the words reiðask 'become angry', reiði 'anger', and reiðr 'anger' are used.

Gunnarr is not royal by blood. However, several methods are used in the saga to allude to his aristocratic and knightly image. When he is introduced, the description is that of a sublime noble hero. Apart from his beautiful appearance, ruddy cheeks and golden hair, he is described as big and strong and the most skilled of all men in battle (53).

Hann skaut manna bezt af boga ok hœfði allt pat, er hann skaut til; hann hljóp meir en hæð sína með ollum herklæðum, ok eigi skemmra aptr en fram fyrir sik; hann var syndr sem selur, ok eigi var sá leikr, at nokkurr byrfti við hann at keppa, ok hefir svá verit sagt, at engi væri hans jafningi. [...] Manna kurteisastr var hann. (53).

(He shot from a bow better than anyone, and he never missed his mark. He jumped higher than his own height in full armour, and no less backwards than forwards. He could swim like a seal, and there was no game in which there was any point in competing with him, and it has been said that no man was his equal. [...] He was the most courteous of men.)

The word kurteiss 'courteous', used to describe Gunnarr, came into Old Norse through translated romances in the thirteenth century, and the description of Gunnarr includes many features of a courteous knight. Among the traits that define Gunnarr are his superior skills in archery. Archery is described as the noblest sport, hofðingligr, in the konungasögur compilation Heimskringla (1991: 734) but is not common in other genres of Old Norse sagas. 
Additionally, apart from Gunnarr's superhuman physical qualities, gorgeous looks, and extravagant clothes $(82-83,85,150)$, he possesses a magical weapon (80-81) and an animal companion, an Irish royal dog called Sámr who has the intelligence of a man $(173,186)$. The dog is a gift from the grandson of King Myrkjartan of Ireland. This aligns Gunnarr with the noble heroes of the romances, such as the knight Yvain in Chrétien de Troyes' Yvain (le Chevalier au lion), who had a lion by his side. ${ }^{21}$ Much in the same way as the relationship between the lion and Yvain, Sámr can be viewed as a mirror of Gunnarr's psyche, an animal extension of his noble character. Their lives are entwined, for Gunnarr cannot be attacked in his home while the dog lives, as his enemies remark (174). The death of one signals the death of the other.

Such is also the case in the konungasaga of King Óláfr Tryggvason. When the King Óláfr's dog, Vígi, hears of the death of his master, he howls loudly and falls dead as tears fall from his eyes and down his snout (Óláfs saga Tryggvasonar en mesta 1958-2000, II: 299). Accordingly, Gunnarr's enemies need to kill Sámr to reach Gunnarr. They slay the dog with an axe-blow through his skull to his brain - a death that resonates more with descriptions of battles between men rather than an animal being put to death (186). When Sámr is killed, the loudness of his howl is unheard of, and when Gunnarr hears it, it signals for him his own death: "Sárt ertú leikinn, Sámr fóstri, ok búo svá sé til ætlat, at skammt skyli okkar í meðal” (186), 'You have been sorely treated, my fosterling Sámr, and it is to be expected that it is meant to be so that our deaths will not be far apart'. These knightly connotations serve to underline the noble features of Gunnarr further.

The display and mentions of Gunnarr's anger function in the saga as a strategic ruling device. People in the saga who are subordinate to Gunnarr seek to avoid his anger, and when he displays it, they become afraid and do as Gunnarr wishes. Práinn Sigfússon refuses to kill Pórðr leysingjason because he does not want to suffer Gunnarr's anger: "Eigi mun ek pat gera [...] pví at pá mun ek hafa reiði Gunnars" (107), 'I will not do that [...] because then I will have Gunnarr's anger'. In other cases, Gunnarr displays his anger as a threat, such as when he overhears the members of his household recite slanderous poetry, ridiculing his friend and closest ally, Njáll, for lacking a beard. The people are laughing loudly when Gunnarr abruptly enters the room:

${ }^{21}$ On the narrative function of the lion in Yvain, see Hunt (1983). 
Qllum brá við mjǫk, er hann sá inn ganga; pognuðu pá allir, en áđr hafði par verit hlátr mikill. Gunnarr var reiðr mjok [...] „ef nokkurr maðr hermir pessi orð, pá skal sá í brautu verða ok hafa pó reiði mína." En svá stóð peim af honum mikil ógn, at engi porði pessi orð at herma. Síðan gekk hann í braut. (113)

(They were all very taken aback when they saw him enter the room; they all fell silent, but before, there had been much laughter. Gunnarr was very angry [...] "anybody who repeats these words shall be expelled from here and still have my anger." They were so intimidated by him that no one dared to repeat the words. Then he walked away.)

Here, Gunnarr does not threaten physical violence with bare words but threatens something that seems to be much more influential: that anyone acting against his decree "will have his anger". The people, including his wife, become so afraid that they do not dare to contradict his will. The pattern that emerges is that Gunnarr's anger is displayed in a noble, royal way. His anger functions in a demonstrative manner, as a ruling device, illustrating his power, and it follows the same script as ira regis, royal anger.

The frequent mention of Gunnarr's anger might seem to be in contrast to the description of him as "stilltr vel" (53), 'even-tempered', as well as numerous accounts of him showing restraint and temperance when provoked by his wife Hallgerðr and others $(151,94,98,106,117-18,121-$ $22,180)$. The key element here is the control he has over his reactions. As Hildigunnr Starkaðardóttir remarks: “Gunnarr er seinpreyttr til vandræða, en harðdrœgr, ef hann má eigi undan komask” (149), 'Gunnarr is slow to be aroused to hostilities, but hard-hitting if he cannot avoid them'. It is clearly indicated that Gunnarr does not act in haste and his displays of anger are always portrayed as just: only when his patience, mildness, and temperance have been seriously tried through many provocations by his enemies and he is accused of the effeminizing act of crying (135), does he draw the line, become severely angry, and avenges by blood. A fundamental element in the honourable practice of anger is that retribution is conducted justly and in a controlled manner (see Althoff 1998). As Gunnarr prepares for a slaying in revenge, his anger is unfamiliar to his mother, who remarks that she has never seen him look so angry before (136). When Gunnarr returns from the successful vengeance, his friend Njáll implies that Gunnarr has been extremely patient in the events leading up to this and that his reactions are excusable: "hefir pú verit mjok at preyttr" (139), 'you have been severely tried'. Njáll thus describes Gunnarr's anger as righteous and his actions justified. In this 
way, Gunnarr's expression of his anger is in alignment with the emotive script of just royal anger, which serves to situate his character within the noble realm.

\subsection{Gender differences}

In Njáls saga, particular words are repeatedly tied to the same action, such as where it is noted with a formulaic wording that a male gets angry and subsequently insults someone, or more commonly, strikes a blow (Brennu-Njáls saga 1954):

Pá reiddisk Họskuldr, ok var fátt um með peim brœðrum (7)

Pá reiddisk Hǫskuldr ok laust sveininn með sprota [...] sprotinn kom í andlitit, ok sprakk fyrir (29)

Pá reiddisk Porvaldr ok laust hana í andlitit, svá at blœddi (33)

Pá reiddisk Glúmr ok hjó til hans með handsaxi (49)

Gunnarr reiddisk ok mælti: „Illa er pá, ef ek em pjófsnautr“, - ok lýstr hana kinnhest. (124)

Porkell spratt pá upp af mikilli reiði og greip sax sitt [...] ,,skal ek reka saxit í gegnum pik“ (305)
'Then Hǫskuldr became angry, and the relationship between the brothers was strained'

'Then Hoskuldr became angry and struck the boy with a stick [...] the stick hit his face and cut through the skin'

'Then Porvaldr became angry and hit her in the face so it bled'

'Then Glúmr became angry and struck at him with a short sword'

'Gunnarr became angry and said: "It is bad if I am a thief's partner" and slapped her on the cheek.'

'Porkell sprung up with much anger and grabbed his short sword [...] "I will thrust this short sword through you"،

The formula above is only applied to one woman, Pórhildr skáldkona. She catches her husband gazing at a young woman. Her following actions are not a physical slap or a blow, but a verbal one in the form of a couplet:

hon reiðisk ok kveðr til hans kviðling:

„Era gapriplar góðir, gægr er pér í augum,

Práinn“, segir hon. (89)

'she becomes angry and recites a couplet: "The [or: Your] gaping rods are no good, I lechery is in your eyes, I Práinn,” she says.' 
The latter element in gapripill (ripill) can be read as a metaphor for a small penis. ${ }^{22}$ This would provide the meaning that Práinn's "small gaping penis is dysfunctional", which is certainly a great attack on Práinn's manhood. By reciting the couplet, Pórhildr retaliates the disgrace her husband showed her with the power that is available to her - the equivalent of slapping. Her words are such an insult that her husband's reaction is swift, swifter than in any of the other cases where this formula is applied. Práinn immediately throws Pórhildr out of the house, announces their divorce, and replaces her with the young woman he was gazing at. Pórhildr is severely reprimanded for her display of anger, the scene not only marks her exit from the house and her marriage but also from the saga. However, while the account of Pórhildr's fate unfolds in the above manner in the saga text, the outcome of the plot on another narrative level is considerably in Pórhildr's favour: With the insult being in verse, it adheres to the tale of the events to Práinn's shame, and the saga's subsequent portrayal of him is less than favourable. ${ }^{23}$

The case of Pórhildr's anger is one of the few instances in which the feelings of a woman are expressed with an emotion word in Njáls saga. That only occurs twenty-four times. ${ }^{24}$ Two aspects are most noteworthy about the use of words regarding women's emotions: the gender difference in the use of words connoting anger and the depiction of Hallgerðr Hǫskuldsdóttir's emotions.

\subsection{Words for female anger}

Slightly different words are used for the emotions of women and men. Both genders are blior 'tender, affectionate' and feginn 'joyful', and both

\footnotetext{
${ }^{22}$ Ripill here has the meaning a "thin rod", see "ripill” in Íslensk orðabók (Mörður Árnason 2007). The compound word Hafalda-ripill refers to an object used in weaving for the purpose of binding loops (literally "loop-rod"), see Matthías Pórðarson (1914: 17). This creates a reference to a rod-shaped tool entering loops, a powerful imagery from the feminine sphere for her husband's dysfunctional sexual abilities.

${ }^{23}$ Práinn is repeatedly portrayed as a flawed and impetuous character, as is thoroughly analysed by Ármann Jakobsson (2009).

${ }^{24}$ See further below, but thirteen of those cases concern Hallgerðr: allkátr (32), ást (47), beiskr (104), bliðða (33), djarfliga (85), feginn (183), geisa (99), skappungt (31, 34), stilla sik (48), and unna $(31,44,48)$. Five instances are about Unnr Marðardóttir: skappungt (22), dapr (22), blíðr (25-26), and vera fátt um með (22); one about Bergpóra: geisa (114). Additionally, the feelings of Gunnarr's mother Rannveig are noted twice: feginn (192) and œði mikil (194), and once each in the cases of Pórhildr skáldkona: reiðask (89); Hildigunnr Starkaðardóttir: skappungt (290), and Gunnarr's aunt, Guðlaug: unna (424).
} 
men and women unna 'love'. However, some words are only used to describe women's feelings. All of these instances are in matters related to their spouses, as in most of the twenty-four cases. Dapr 'sad' is reserved for a single person, denoting Unnr Marðardóttir's depressed feelings about her marriage with Hrútr (22). Hallgerðr is the only person who becomes beiskr 'embittered' (104). Skappungt 'sad', literally: 'of heavy mind' appears four times, all in cases about women. ${ }^{25}$

A woman's anger is mentioned four times. Apart from reiðask in the above example of Pórhildr skáldkona, the verb geisa (with the amplifying adverb mjok) is used twice, and $\propto$ ¿ $i$ (with the amplifier mikil) is used once:

Hallgerðr leitaði á Gunnar mjọk, er hann hafði sætzk á vígit [...] hon geisaði mjok.

[Bergbóra] kom innar í annat sinn ok geisaði mjok. (114)

Rannveig spratt upp af œði mikilli. (194)
'Hallgerðr harassed Gunnarr much for having settled the slaying $[\ldots]$ she raged greatly'.

'Bergpóra came in again and raged greatly'.

'Rannveig jumped up in great rage'.

Geisa refers to rage, raving, and a rampage: to lose control. It is often used in Old Norse texts to describe warfare, fire, or destructive and wild waters and sea. ${ }^{26} E \partial i$ similarly refers to frenzy, fury, and even madness. These words connote a much more unrefined, uncontrolled expression of anger than the royal anger or noble anger that has an outlet in just actions, which is described above in the cases of men. Both geisa and $е ð i$ connote a loss of control or extremes: something bursting open with force and fury. This is thus a different kind of anger (or expression of anger) than when the word reiðask is used, and it is exclusively used concerning women in Njáls saga.

These uncontrolled expressions of women's anger are met with disdain. As noted above, Pórhildr's husband becomes furious, divorces her on the spot, and throws her out of the house. Hallgerðr's expression of anger using the terms geisaði mjok is dismissed with an ignoring silence by

\footnotetext{
${ }^{25}$ Unnr Marðardóttir (22); Hallgerðr Họskuldsdóttir $(31,34)$; Hildigunnr Starkaðardóttir (290). The word is mentioned once in four other sagas, Fljótsdcela saga, Hallfreðar saga vandræðaskálds, Vápnfirðinga saga, and Fóstbrœðra saga, in each case referring to a woman, except in Fóstbrœðra saga. See "skappungt" in Mörkuð ílensk málheild: Fornrit; and "skappungr" in Ordbog over det norrøne prosasprog.

${ }^{26}$ See examples of "geisa" in Ordbog over det norrøne prosasprog.
} 
her husband: "Gunnarr gaf eigi gaum at pvî” (99), 'Gunnar ignored this'. When Bergpóra geisaði mjǫk 'raged greatly', her husband Njáll reacts in a similar depreciating way, advising a calm reaction (114), and her son Skarpheðinn demeans his mother's expression with these words: "Ekki họfu vér kvenna skap [...] at vér reiðimsk við olllu” (114), "We do not have the temper of women, who become angry over anything' ${ }^{27}$

\subsection{Words used about Hallgerðr}

As noted above, women's emotions are mentioned twenty-four times in the saga. Thirteen of those cases concern Hallgerðr, which emphasizes her central role in the first part of the saga. In comparison, only Gunnarr's and Flosi Pórðarson's emotions are mentioned more often. The following list shows the number of times for the characters whose feelings are most frequently referred to with emotion words:

29 Gunnarr Hámundarson

17 Flosi Pórðarson

13 Hallgerðr Hǫskuldsdóttir

8 Kári Sǫlmundarson

8 Jarl Hákon

7 Skarpheðinn Njálsson

7 Mǫrðr Valgarðsson

6 Njáll Porgeirsson

The emotion words used about Gunnarr mostly refer to his anger or courage (twenty-one out of twenty-nine) in various feuds and political situations, with the important and notable exception of when he expresses his regret of being forced to slay people (139). In contrast, the emotion words used about Hallgerðr are more expressive and nuanced and offer a deeper view into her psyche, underlining her complexity as a character

\footnotetext{
${ }^{27}$ In all those three cases, the women have attacked or put in question the men's honour. However, this is not the case when Gunnarr's mother Rannveig has œð i mikil, and in that case her expression is not met with disdain. For the treatment of women in Njáls saga and female gender roles in the saga, see Dronke (1981) and essays by Helga Kress (1996). On how the saga discusses gender roles in relation to masculinity in particular, see Ármann Jakobsson (2007).
} 
- as opposed to Gunnarr who is portrayed on a narrower emotional spectrum as a somewhat stereotypical idealized saga hero.

Hallgerðr is a proud woman, who is described as tall and beautiful with long, silky hair $(6,29)$. She is noted to be "skaphorð” (29) 'of harsh temper' by the narrator and "blandin mjok" (86) 'of mixed temperament' by her uncle, and this is stated to be a significant defect and bad currency when negotiations of her marriages are conducted (42,86-87). Blandin mjok insinuates insidiousness and a duplicitous nature, alluding to her many sides that are portrayed in the saga ${ }^{28}$ Hallgerðr's character is unruly and provocative and is representative of an ambivalent strong female figure who disturbs the patriarchal hierarchy within the saga, and also receives the blame for quite a few misfortunes that unfold in the narrative. ${ }^{29}$

However, it is possible to discern a slightly more tender portrayal of her emotions before her marriage to Gunnarr than after she marries him. The first time Hallgerðr's feelings are noted using an emotion word is when her father betroths her to her first husband without asking for her consent. She sadly conveys to her father that this confirms what she long suspected, "at pú mundir eigi unna mér svá mikit sem pú sagðir jafnan” (31), 'that you do not love me as much as you have often said', and the narrator further notes that this makes her "skappungt" (31) 'sad', lit. 'of heavy mind'. However, she is already plotting to get rid of Porvaldr, the husband, and perhaps because of that, she is "allkát" (32) 'very cheerful' at their wedding and deceptively shows "blíðu” (33) 'tenderness' towards Porvaldr. Soon after, Porvaldr slaps her and again she becomes "skappungt” (34) 'sad' and has him killed. Glúmr Óleifsson is her next husband, whom she loves very much, as she says herself: "Vel er um ástir okkrar" (47), 'the love between us is good' Their interaction even includes a description of her embracing him (47), a rare gesture to be noted in the sagas. ${ }^{30}$ When Glúmr slaps her too, the description of her feelings is unusually rich: "Hon unni honum mikit ok mátti eigi stilla sik ok grét hástǫum” (48), "She loved him much and could not control herself and cried loudly'. Here, it is both noted how much she loved Glúmr and that her emotions are unrestrained, as in the case of the anger of Bergpóra, Pórhildr, and Rannveig. Another exceptional word is used when

\footnotetext{
${ }^{28}$ Zoe Borovsky explores the connotations of adj. blandinn in Old Norse myths and suggests that, in Hallgerðr's case, it is to be taken as a reference to paganism and the old value system, along with allusions to otherness, "a "giant" past that disrupts" the peaceful order. Borovsky (2002: 10-11)

${ }^{29}$ On Hallgerðr's figure, see, e.g., Heinrichs (1994); Helga Kress (2007).

${ }^{30}$ See examples from the corpus of embracing in Wolf (2013: 110-11).
} 
she meets Gunnarr for the first time, and it is noted how "djarfliga" (85) 'daringly, boldly' she speaks to him in their courting scene. This seems to be the only example in the whole corpus of Íslendingasögur where this word is used about a woman. ${ }^{31}$ However, at this point in the saga, the descriptions of her tender heavy mood or feelings of affection end, and words that depict her as more emotionally strained and angry begin to be used.

After having married Gunnarr, she is often cross at him for not reacting to Bergpóra's insults towards her. The insults make her "beisk" (104) 'embittered, acrimonious' and once she "geisaði mjok" (99) 'raged greatly' towards Gunnarr, which, as described above, insinuates uncontrolled anger. There are frequent efforts to tame and discipline her: "Ver pú dæl, meðan ek em heiman, ok sýn af pér enga fárskapi, par sem við vini mína er um at eiga" Gunnarr warns her (92), 'Be compliant while I am away, and do not exercise any malevolence where my friends are concerned'. "Trǫll hafi pína vini”, she replies (92), 'May trolls have your friends'. Gunnarr later slaps Hallgerðr for thievery, to which she answers coldly that she will remember that slap and repay it (124). When Gunnarr decides to stay in Iceland at the risk of being killed with impunity, she becomes "fegin" (183) 'joyful' and it is left ambiguous in the text whether she is joyful out of pride that her husband does not yield to his enemies or because she knows this most likely signals his death.

Thus, though Hallgerðr's feelings are mentioned much less frequently with emotion words than Gunnarr's feelings are, the words that are used provide the reader with a wider and more intense range of emotions from intimate love to fierce contempt, from heavy heart to cheerfulness and great rage - which produces more insight into her psychology than most other characters. This also demonstrates how specifically the emotive vocabulary of the saga is used, as many words are bespoke for the occasion and character.

\section{Conclusion}

This essay described the development and construction of the first lexicons of emotion words in Njáls saga and Egils saga. The lexicons

\footnotetext{
${ }^{31}$ According to a search for "djarflegur" in all forms in the database Mörkuð islensk málheild: Fornrit.
} 
were presented and analysed. It was confirmed that both sagas have a vocabulary for a large spectrum of emotions. These are divided into many categories, each including a range of expressions. Furthermore, it was established how the lexicons can be used as a tool for uncovering narrative patterns, literary constructions of gender and status, and formulas for character development. The analysis reveals that the two works apply their emotional vocabulary in somewhat different settings and scenes, and different categories are prominent.

Egils saga has a slightly larger vocabulary of emotion words. It also has numerous instances of communicating anger, joy, and love in the context of royal anger, which resonates with the fact that aspects of the saga bear a resemblance to the genre of konungasögur. The fact that the biggest emotion categories in the saga are JOY and LOVE can be explained by this feature, and this does not indicate that these are prominent emotional themes in the saga as a whole. This underlines how individual scenes, or a particular formula, skews the overall picture that the lexicon reveals, and advises that no assumptions about the general themes in these sagas can be made based only on a list or a word count. Furthermore, the results show that Egils saga fits the general assumption of self-expression and the narrative voice in Íslendingasögur, in the sense that the majority of the emotion words in Egils saga are spoken by the narrator, but if the word is spoken by a character about his or her own emotions, it is most often in poetry where a more internal perspective can be found.

Njáls saga, on the other hand, has more characters expressing themselves directly regarding their own inner state. Clear gender differences exist in the application of specific words, where some words are only used about women, such as skappungt 'sad, of heavy mind', geisa 'rage', and $е ð i$ mikil 'great rage'. Few cases of this exist, but they nevertheless show that women's anger is termed differently and has different characteristics than men's anger; the connotation of the words is that female anger is less controlled and wilder and calls for reactions of disdain.

It is notable that each of the two sagas has a rather different set of emotion words. When the two lexicons are taken together, they include 164 individual words. Only thirty-six of them are found in both sagas. The analysis further reveals that only a minority of the words $35 \%$ in Njáls saga and 24\% in Egils saga) are used more than once or twice. In many cases, these more common words form a part of a narrative formula, where similar or the same wording is applied in a similar setting throughout the work. This is the case of anger words in the context of royal anger, 
of rejoicing at the return of someone with the words feginn and feginsamliga, and the case of describing being in an intimate relationship with a king with the word karleikr. The majority of the words $(65 \%$ in Njáls saga and $76 \%$ in Egils saga) are only used once or twice and are thus applied in specific, precise settings.

When the above is considered, the emotional vocabulary of Egils saga and Njáls saga can indeed be regarded as diverse and varied, and containing terms for a broad spectrum of emotions. It has been shown here how emotion words are applied in a customized and selected way to describe the emotions of the poet Egill and of Ásgerðr, Hallgerðr, Bergpóra, Gunnarr, and Njáll as well as other characters, and each bespoke choice of words emphasizes the specific features of the characters and their function and place within the narrative. Furthermore, I have addressed how the specificity of the application of the words underlines ideas of femininity, masculinity, status, and honour. The fact that most of the words are used for a particular purpose demonstrates that emotion words are applied in the saga in a systematic and precise way. The variety of nuances within the same emotion category further demonstrates the breadth of the emotive vocabulary. These findings do not altogether agree with previous views that maintain that the emotive vocabulary of the sagas is poor and not very nuanced and that the use of emotion words in them is infrequent and limited.

In the absence of a similar study on other literary works, either medieval or modern, it is difficult to estimate whether the frequency of emotion words in Njáls saga and Egils saga should be considered high or low compared to other works. In Egils saga, 3.1\% of the lexemes are emotion words, which is slightly more than in Njáls saga, where $2.5 \%$ of the lexemes are emotion words. The sagas are also somewhat similar in how often emotion words are applied. The total word count of emotion words in Njáls saga is $0.25 \%$ of the total word count in the saga. In Egils $\operatorname{sag} a$, the proportion of emotion words is slightly higher at $0.31 \%$ of all the words of the saga.

A brief examination of the short Viglundar saga can provide at least one indicative point of comparison. Víglundar saga is a love story that is categorized as an Íslendingasaga but has strong stylistic features associated with romances (see Jóhannes Halldórsson 1959: xxxi; Vésteinn Ólason 2006: 157-58). The saga includes twenty-two stanzas and is classified as a late saga, argued to be composed in the early fifteenth century (Vésteinn Ólason 2005: 115). The Svart á hvítu edition, which is available 
in a digital form, is included in the database Mörkuð islensk málheild and includes 12,585 words. Ninety-four occurrences of emotion words can be listed from the saga by the same method and criteria as described above. Thus, $0.74 \%$ of the words in the saga are emotion words, which is a greater ratio than in Njáls saga and Egils saga.

The strong stylistic romance features of the saga manifest for example in the following passage, which includes expressions in a style that would be unthinkable in Egils saga and Njáls saga:

En pau unnust pví heitara með leyniligri ást ok fólginni elsku peim í brjósti pegar í fyrstu, er pau váru uppvaxandi, svá at rætr elskunnar ok uppvöxtr ástarinnar, er aldri varð upprættr ór peira hjörtum, eptir pví sem náttúra er amorsins, at eldr yndisins ok logi elskunnar brennr pví heitara ok sækir pví meir brjóst ok hjörtu mannanna saman sem fleiri vilja peim meina [...] (Víglundar saga 1959: 82).

(But they loved each other even more with secret affection and love that was hidden in their bosom, from the time when they were growing up, so that the roots of affection and the growth of love could never be uprooted from their hearts, because such is the nature of amor, that the fire of pleasure and the flame of love burns hotter, and more strongly besets the breasts and hearts of men, as more people try to forbid it $[\ldots]$ )

This passage includes long strings of emotion words where the amorous feelings of Víglundr and Ketilríor are analysed, explained, and pondered adding references to heat and fire. It is hardly a surprise that almost half (forty) of the occurrences of emotion words in Víglundar saga denote love or affection. However, almost all the emotion words in this passage from Víglundar saga are also found in Njáls saga. The difference between the two sagas' depiction of emotions rather consists in how these words are used. Each time amorous feelings between a man and woman are communicated through words in Njáls saga, only one or two emotion words are applied:

[Hallgerðr] unni [Glúmi] mikit ok mátti eigi stilla sik ok grét hástǫfum. (48)

Práinn unni [Pórhildi] lítit. (87)

„Vel er um ástir okkrar“. (47)

Gunnarr lagði hug á Bergljótu, frændkonu jarls. (83)
'Hallgerðr loved Glúmr much and could not contain herself and cried loudly'.

'Práinn loved Pórhildr little'.

“"The love between us is good".

'Gunnarr desired Bergljót, kinswoman of the jarl'. 
Here, the articulation is blunt and not dwelt on through words with emotive content. Perhaps it is primarily in this sense that the claims that the readers of sagas are "seldom assisted by native emotion words" (Miller 1992: 107), can be justified. Emotive scenes in both Njáls saga and Egils saga certainly do contain emotion words, but they do not form a part of a string of such words when they appear, nor is emotive language used to elaborate on the emotions. Rather, the words appear few at a time and are applied in a specific, concise way. Moreover, the connotations and placements of the words in the text are loaded with meaning that should not be overlooked as inconsequential in the literary interpretation of the sagas.

\section{Bibliography}

\section{Manuscripts}

Den Arnamagnceanske Samling, Copenhagen

AM 468 4to (Reykjabók)

Stofnun Árna Magnússonar í íslenskum fraðum, Reykjavík

AM 132 fol. (Möðruvallabók)

AM 133 fol. (Kálfalækjarbók)

AM 462 4to (Ketilsbók)

AM 551 a 4to

\section{Primary Sources}

Brennu-Njáls saga, 1954. Ed. by Einar Ó1. Sveinsson. Íslenzk fornrit 12. Reykjavík: Hið íslenzka fornritafélag.

Brennu-Njáls saga, 1985. Ed. by Jón Torfason and others. In: Íslendingasögur. Vol. 1. Reykjavík: Svart á hvítu. Pp. 124-345.

Egils saga, 1985. Ed. by Jón Torfason and others. In: Íslendingasögur. Vol. 1. Reykjavík: Svart á hvítu. Pp. 368-518.

Egils saga Skalla-Grímssonar, 1933. Ed. by Sigurður Nordal. Íslenzk fornrit 2. Reykjavík: Hið íslenzka fornritafélag.

Egils saga Skallagrímssonar, tilligemed Egils större kvad, 1886-88. Ed. by Finnur Jónsson. Copenhagen: Samfund til udgivelse af gammel nordisk litteratur.

Fljótsdcela saga, 1950. Ed. by Jón Jóhannsson. In: Austfirðinga sǫgur. Íslenzk fornrit 11. Pp. 213-96. Reykjavík: Hið íslenzka fornritafélag. 
Fóstbrœðra saga, 1943. Ed. by Guðni Jónsson. In: Vestfirðinga sǫgur. Íslenzk fornrit 6. Pp. 121-276. Reykjavík: Hið íslenzka fornritafélag.

Hallfreðar saga vandrceðaskálds, 1939. Ed. by Einar Ól. Sveinsson. In: Vatnsdœla saga, Hallfreðar saga, Kormáks saga, Hrómundar páttr halta, Hrafns páttr Guðrúnarsonar. Íslenzk fornrit 7. Pp. 133-200. Reykjavík: Hið íslenzka fornritafélag.

Heimskringla $=$ Snorri Sturluson, 1991: Heimskringla. Ed. by Bergljót S. Kristjánsdóttir and others. 2 vols. Reykjavík: Mál og menning.

Njála: Udgivet efter gamle håndskrifter af Det kongelige nordiske oldskriftselskab, 1875-1889. Ed. by Konráð Gíslason and Eiríkur Jónsson. 2 vols. Copenhagen: Det Kongelige Nordiske Oldskrift-Selskab.

Óláfs saga Tryggvasonar en mesta , 1958-2000. Ed. by Ólafur Halldórsson. 3 vols . Editiones Arnamagnæanæ, Series A, 1-3. Copenhagen: Ejnar Munksgaard.

Vápnfirðinga saga, 1950. Ed. by Jón Jóhannesson. In: Austfirðinga sögur. Íslenzk fornrit 11. Reykjavík: Hið íslenzka fornritafélag. Pp. 23-65.

Víglundar saga, 1959. Ed. by Jóhannes Halldórsson. In: Kjalnesinga saga. Íslenzk fornrit 14. Reykjavík: Hið íslenzka fornritafélag. Pp. 61-116.

\section{Secondary Literature}

Althoff, Gerd, 1998: "Ira Regis": Prolegomena to a History of Royal Anger. In: Anger's Past: The Social Uses of an Emotion in the Middle Ages. Ed. by B. H. Rosenwein. Ithaca: Cornell University Press. Pp. 59-74.

Ármann Jakobsson, 2002: Our Norwegian Friend: The Role of the King in the Family Sagas. Arkiv för nordisk filologi 117. Pp. 145-160.

—, 2007: Masculinity and Politics in Njáls saga. Viator 38. Pp. 191-215.

- , 2008: "Egils saga" and Empathy: Emotions and Moral Issues in a Dysfunctional Saga Family. Scandinavian Studies 80. Pp. 1-18.

—-, 2009: The Impetuousness of Práinn Sigfússon: Leadership, Virtue and Villainy in Njáls saga. Arkiv för nordisk filologi 124. Pp. 52-67.

Bandlien, Bjørn, 2005: Man or Monster? Negotiations of Masculinity in Old Norse Society. Doctoral thesis, University of Oslo.

Barton, Richard E., 1998: "Zealous Anger" and the Renegotiation of Aristocratic Relationships in Eleventh- and Twelfth-Century France. In: Anger's Past: The Social Uses of an Emotion in the Middle Ages. Ed. by B. H. Rosenwein. Ithaca: Cornell University Press. Pp. 153-170.

Borovsky, Zoe, 2002: "En hon er blandin mjok": Women and Insults in Old Norse literature. In: Cold Counsel: Women in Old Norse Literature and Mythology. Ed. by S. M. Anderson and K. Swenson. London: Routledge. Pp. 1-14.

Bredsdorff, Thomas, 2001: Chaos and Love: The Philosophy of the Icelandic Family Sagas. Trans. by John Tucker. Copenhagen: Museum Tusculanum Press, University of Copenhagen.

Clore, Gerald L., Andrew Ortony, and Mark A. Foss, 1987: The Psychological 
Foundations of the Affective Lexicon. Journal of Personality and Social Psychology 53. Pp. 751-766.

Dronke, Ursula, 1981: The Role of Sexual Themes in Njáls saga. London: Viking Society for Northern Research, University College London.

Ekman, Paul, 1994: All Emotions are Basic. In: The Nature of Emotions: Fundamental Questions. Ed. by P. Ekman and R. J. Davidson. Oxford: Oxford University Press. Pp. 15-19.

Ekman, Paul, and Daniel Cordaro, 2011: What is Meant by Calling Emotions Basic. Emotion Review 3. Pp. 364-370.

Goddard, Cliff, and Anna Wierzbicka, 2014: Words and Meanings: Lexical Semantics Across Domains, Languages, and Cultures. Oxford: Oxford University Press.

Hallberg, Peter, 1966: Några anteckningar om replik och dialog i Njals saga. In: Festschrift Walter Baetke dargebracht zu seinem 80. Geburtstag am 28. März 1964. Ed. by K. Rudolph, R. Heller and E. Walter. Weimar: Hermann Böhlaus Nachfolger. Pp. 130-150.

Haukur Porgeirsson, 2018: How Similar are Heimskringla and Egils saga? An Application of Burrows' Delta to Icelandic Texts. European Journal of Scandinavian Studies 48. Pp. 1-18.

Heinrichs, Anne, 1994: Hallgerðrs Saga in der Njála: Der doppelte Blick. In: Studien zum Altgermanischen: Festschrift für Heinrich Beck. Ed. by H. Uecker. Berlin: De Gruyter. Pp. 327-53.

Helga Kress, 1996: Fyrir dyrum fóstru: Greinar um konur og kynferði í íslenskum fornbókmenntum. Reykjavík: Háskóli Íslands, Rannsóknarstofa í kvennafræðum.

__, 2007: "Fá mér leppa tvo": Nokkur orð um Hallgerði og hárið. Torfhildur 1. Pp. 96-109.

Hunt, Tony, 1983: The Lion and Yvain. In: The Legend of Arthur in the Middle Ages: Studies Presented to A. H. Diverres by Colleagues, Pupils and Friends. Ed. by P. B. Grout, R. A. Lodge, C. E. Pickford and E. K. C. Varty. Cambridge: Brewer. Pp. 86-98.

Izard, Carrol E., 1977: Human Emotions. London: Plenum Press.

Jóhannes Halldórsson, 1959: Formáli. In: Kjalnesinga saga. Ed. by Jóhannes Halldórsson. Íslenzk fornit 14. Reykjavík: Hið íslenzka fornritafélag. Pp. vlxxvi.

Johnson-Laird, P. N., and Keith Oatley, 1989: The Language of Emotions: An Analysis of a Semantic Field. Cognition and Emotion 3. Pp. 81-123.

Jón Viðar Sigurðsson, 2017: Viking Friendship: The Social Bond in Iceland and Norway, c. 900-1300. Ithaca: Cornell University Press.

Kaster, Robert A., 2005: Emotion, Restraint, and Community in Ancient Rome. Oxford: Oxford University Press.

Knuuttila, Simo, 2004: Emotions in Ancient and Medieval Philosophy. Oxford: Oxford University Press. 
Larrington, Carolyne, 2015: Learning to Feel in the Old Norse Camelot? Scandinavian Studies 87. Pp. 74-94.

Matthías Pórðarson, 1914: Ýmislegt um gamla vefstaðinn. In: Árbók Hins íslenzka fornleifafélags. Reykjavík: Hið íslenzka fornleifafélag. Pp. 17-26.

Meulengracht Sørensen, Preben, 1983: The Unmanly Man: Concepts of Sexual Defamation in Early Northern Society. Trans. by Joan Turville-Petre. Odense: Odense University Press.

Miller, Willam Ian, 1992: Emotions and the Sagas. In: From Sagas to Society: Comparative Approaches to Early Iceland. Ed. by Gísli Pálsson. Middlesex: Hisarlik Press. Pp. 89-109.

- 1993: Humiliation and Other Essays on Honor, Social Discomfort, and Violence. Ithaca: Cornell University Press.

Mörður Árnason (ed.), 2007: Íslensk orðabók. 4th ed. Reykjavík: Edda. <https:// snara.is>.

Mörkuð íslensk málheild: Fornrit. Stofnun Árna Magnússonar í íslenskum fræðum, 2012-2017. <http://mim.arnastofnun.is/>.

Niedenthal, Paula M., 2008: Emotion Concepts. In: Handbook of Emotions. Ed. by M. Lewis, J. M. Haviland-Jones and L. Feldmann Barrett. New York: Guilford. Pp. 587-600.

OED Online. Oxford English Dictionary. Oxford University Press. <http://oed. com>.

Ordbog over det norrøne prosasprog. Index of medieval manuscripts. Den Arnamagnæanske Kommission. <http://onp.ku.dk/>.

Porter, Edel, and Teodoro Manrique Antón, 2015: Flushing in Anger, Blushing in Shame: Somatic Markers in Old Norse Emotional Expressions. Cognitive Linguistic Studies 2. Pp. 24-49.

Rosch, Eleanor, 1978: Principles of Categorization. In: Cognition and Categorization. Ed. by E. Rosh and B. B. Lloyd. Hillside: Erlbaum. Pp. 27-48.

Rosenwein, Barbara H., 2008: Emotion Words. In: Le sujet des émotions au moyen âge. Ed. by P. Nagy and D. Boquet. Paris: Beauchesne.

_, 2010: Thinking Historically about Medieval Emotions. History Compass 8, 828-842.

Russell, James A., 1991: Culture and the Categorization of Emotions. Psychological Bulletin 110. Pp. 426-450.

Russell, James A., and Ghyslaine Lemay, 2000: Emotion Concepts. In: Handbook of Emotions. Ed. by M. Lewis and J. M. Haviland-Jones. New York: Guilford. Pp. 491-503.

Shweder, Richard A., Jonathan Haidt, Randall Horton, and Craig Joseph, 2008: The Cultural Psychology of the Emotions: Ancient and Renewed. In: Handbook of Emotions. Ed. by M. Lewis, J. M. Haviland-Jones and L. Feldman Barrett. New York: Guilford Press. Pp. 409-427.

Sif Rikhardsdottir, 2017: Emotions in Old Norse Literature: Translations, Voices, Contexts. Cambridge: Brewer. 
Svanhildur Óskarsdóttir, 1991: Um Brennu-Njáls sögu. In: Brennu-Njáls saga. Ed. by Örnólfur Thorsson. Reykjavík: Mál og menning. Pp. vii-xxv.

Sverrir Tómasson, and Örnólfur Thorsson, 1991: Um Íslendinga sögur. In: Brennu-Njáls saga. Ed. by Örnólfur Thorsson. Reykjavík: Mál og menning. Pp. 483-557.

Sävborg, Daniel, 2007: Sagan om kärleken: Erotik, känslor och berättarkonst i norrön litteratur. Acta Universitatis Upsaliensis 27. Historia litterarum. Uppsala: Uppsala University.

__, 2017: Style. In: The Routledge Research Companion to the Medieval Icelandic Sagas. Ed. by Ármann Jakobsson and Sverrir Jakobsson. London: Routledge. Pp. 111-127.

Torfi H. Tulinius, 2004: Skáldið í skriftinni: Snorri Sturluson og Egils saga. Ritröð Reykjavíkur Akademíunnar og Hins íslenska bókmenntafélags 3. Reykjavík: Hið íslenska bókmenntafélag, Reykjavíkur Akademían.

Vésteinn Ólason, 1994: Emosjon og aksjon i “Njáls saga”. Nordica Bergensia 3. Pp. 157-172.

_- 1998: Dialogues with the Viking Age: Narration and Representation in the Sagas of the Icelanders. Trans. by Andrew Wawn. Reykjavík: Heimskringla.

__, 2005: Family Sagas. In: A Companion to Old Norse-Icelandic Literature and Culture. Ed. by R. McTurk. Oxford: Blackwell. Pp. 101-118.

__, 2006: Íslendingasögur og pættir. In: Íslensk bókmenntasaga. Ed. by Vésteinn Ólason. Reykjavík: Mál og menning. Pp. 23-163.

White, Stephen D., 1998: The Politics of Anger. In: Anger's Past: The Social Uses of an Emotion in the Middle Ages. Ed. by B. H. Rosenwein. Ithaca: Cornell University Press. Pp. 127-152.

Wierzbicka, Anna, 1986: Human Emotions: Universal or Culture-Specific? American Anthropologist 88. Pp. 584-594.

__, 1999: Emotions Across Languages and Cultures: Diversity and Universals. Cambridge: Cambridge University Press.

Wolf, Kirsten, 2013: Body Language in Medieval Iceland: A Study of Gesticulation in the Sagas and Tales of Icelanders. Scripta Islandica 64. Pp. 99-122.

__, 2014: Somatic Semiotics: Emotion and the Human Face in the Sagas and Pættir of Icelanders. Traditio 69. Pp. 125-145.

Porleifur Hauksson, and Pórir Óskarsson, 1994: Íslensk stílfræði. Reykjavík: Styrktarsjóður Pórbergs Pórðarsonar og Margrétar Jónsdóttur, Mál og menning. Pórir Óskarsson, 2005: Rhetoric and Style. In: A Companion to Old NorseIcelandic Literature and Culture. Ed. by R. McTurk. Oxford: Blackwell. Pp. 354-371. 


\section{Summary}

Even though scholars have often maintained that the Old Norse Íslendingasögur (Sagas of Icelanders) are poor in emotional vocabulary, the emotion words in them have not been comprehensively explored. In this essay, I explain my construction of database of the words used to express feelings in two of the longest sagas, Njáls saga and Egils saga. The method used enabled the plotting of various variables, such as character, gender, social status, and speaker, against one another. This uncovered narrative patterns and formulas for action, as well as allowing the identification of anomalies and the production of the first lexicons of the two sagas' emotional vocabulary. The results demonstrate that, contrary to what has often been assumed, the sagas contain a wide variety of emotion words that are applied systematically, precisely, and purposefully to achieve specific narrative aims.

Keywords: Emotion words, emotional lexis, lexical investigation, Íslendingasögur, Sagas of Icelanders, Egils saga, Njáls saga

Brynja Porgeirsdóttir

University of Cambridge

Department of Anglo-Saxon, Norse, and Celtic

Cambridge CB3 9DP

United Kingdom

bt346@cam.ac.uk

brynjathorgeirsdottir@gmail.com

ORCID iD 0000-0003-1474-5604 


\title{
Medieval Poetry in Post-medieval Manuscripts New Perspectives on the Transmission History of Griplur
}

\author{
KATARZYNA ANNA KAPITAN
}

\section{Introduction}

Remarkably undervalued by scholars, rimur (a type of Icelandic stanzaic narrative poetry, sg. ríma) were one of the most popular genres of Icelandic literature for centuries. They have received a limited amount of scholarly attention when compared to their prose counterparts. ${ }^{1}$ This is surprising, since even a brief examination of Rimnatal, the extensive catalogue of the Icelandic rimur (Finnur Sigmundsson 1966), reveals that numerous sagas exist in metric adaptations in the form of rimur and some of them were converted into this form on more than one occasion. While studies of the transmission histories of various sagas are gaining increasing popularity among scholars, as manifested by projects such as "The

\footnotetext{
${ }^{1}$ For an introduction to the genre see: Björn K. Pórólfsson (1934); Craigie (1949); Davíð Erlingsson (1989); Driscoll (2011); Glauser und Tranter (1990); Hughes (1980, 1982, 2005); Stefán Einarsson (1955); Sverrir Tómasson (2012). The major editions of rímur appeared in the series Rit Rímnafélagsins, published by Rímnafélag, and the series Íslenzkar miðaldarímur, published by Stofnun Árna Magnússonar. The most recent edition of rímur was published in 2015 by Jóhanna Katrín Friðriksdóttir and Haukur Porgeirsson as a journal article in Gripla, while the most recent English translation of rimur was published by Philip Lavender in 2019.
}

Kapitan, Katarzyna Anna. 2020. Medieval Poetry in Post-medieval Manuscripts:

New Perspectives on the Transmission History of Griplur.

Scripta Islandica 71: 51-98.

(C) Katarzyna Anna Kapitan (CC BY)

DOI: $10.33063 /$ diva-429320 
Variance of Njáls saga"2 and "Stories for all time", ${ }^{3}$ the textual criticism and transmission studies of rímur are far less frequent and arguably less influential. The notable exceptions are the recent studies of Illuga saga and Úlfhams saga, in which the authors not only examined textual relationships among witnesses of the respective sagas and rimur but also revealed their intertextual relations (Lavender 2020; Aðalheiður Guðmundsdóttir 2001).

Even though rímur are usually mentioned only in passing in discussions of the literature of medieval Iceland, one set of rímur appears unproportionally often: the set of rímur of Hrómundur, known as Griplur or Hrómundarrímur. ${ }^{4}$ While according to Landnámabók Hrómundur was a forefather of the first settlers of Iceland Ingólfur and Leifur, ${ }^{5}$ Griplur most likely owe their privileged position in the history of Icelandic literature to the assumption that they are based on a lost medieval saga, which was supposedly recited at the wedding feast in Reykhólar in 1119. The famous passage describing this wedding feast can be found in Porgils saga ok Hafliða, a part of the Sturlunga compilation (Kålund 1906-1911; Brown 1952; Halldór Hermannsson 1945). Even though it has been frequently cited in the literature, it is worth repeating also here due to its importance for the transmission history of the story of Hrómundur.

Hrólfr af Skálmarnesi sagði soggu frá Hrǫ[n]g[vi]ði víkingi ok frá Óláfi liðmannakonungi ok haugbroti Práins berserks ok Hrómundi Gripssyni, ok margar vísur með. En pessarri sọgu var skemt Sverri konungi, ok kallaði hann slíkar lygisogur skemtiligastar. Ok pó kunnu menn at telja ættir sínar til Hrómundar Gripssonar. Pessa sǫgu hafði Hrólfr sjálfr samansetta. (Brown 1952: 17-18)

What is important from the perspective of the present study is the fact

\footnotetext{
2 "The Variance of Njáls saga" project was funded by the Icelandic Research Council from 2011 to 2013 and it was completed by the recent publication of the volume on the transmission of Njáls saga (Svanhildur Óskarsdóttir and Lethbridge 2018).

${ }^{3}$ The "Stories for all time" project was funded by the Velux Foundation from 2011 to 2015 and it was completed by the recent publication of the volume on the transmission and reception of the Icelandic legendary sagas (Driscoll et al. 2018). A number of PhD-theses were prepared in connection to this project by Lansing (2011), Hufnagel (2012), Lavender (2014), and as a spin-off also by Kapitan (2018).

${ }^{4}$ Since the title of the poem Griplur (or Hrómundarrímur) reflects the grammatic plural connected to the fact that Griplur consist of more than one rima, I refer to this work in plural.

${ }^{5}$ For the account of Landnámabók see Finnur Jónsson (1900: 6).
} 
that according to Porgils saga ok Hafliða, one of the stories recited at the wedding feast was about Hröngviður, King Ólafur, breaking into Práinn's burial mound, and Hrómundur Gripsson. Even though no manuscript of that medieval *Hrómundar saga survives, thanks to this account we know that the saga recited at the wedding feast was dealing with some of the characters and events known from other extant works. Firstly, the medieval rímur of Hrómundur (Griplur) present a version of the story that consists of all the episodes mentioned Porgils saga, but which is believed to be slightly expanded in relation to the lost medieval saga. Secondly, the post-medieval saga of Hrómundur (Hrómundar saga Greipssonar), as known from all modern editions and translations, is a seventeenth-century prosification of the rimur, which introduces minor changes in relation to its poetic antecedent. ${ }^{6}$ The account of Porgils saga ok Hafliða is the earliest attestation of the existence of some sort of story of Hrómundur Gr(e)ipsson already in the Middle Ages. ${ }^{7}$

Griplur belong to the oldest known sets of rimur, written most likely in the second half of the fourteenth century with the earliest known manuscript dating to the late fifteenth century (Björn K. Pórólfsson 1934; Haukur Porgeirsson 2013). They contain approx. 366 stanzas in six fitts. Each fitt is preceded by a short mansöngur section (opening section of a ríma, pl. mansöngvar) of varied length. Even though Griplur were edited and published twice by Finnur Jónsson, in Fernir forníslenskir rímnaflokkar in 1896 and in Rimnasafn in 1905-1922, and they have been a subject of scholarly discussion, especially in the context of their relationship to the lost saga of Hrómundur and the seventeenth-century saga (Kölbing 1876; Andrews 1911; Björn K. Pórólfsson 1934: 353-363; Brown 1946; Jesch 1984), no study of their full transmission history yet exists. Moreover,

\footnotetext{
${ }^{6}$ The seventeenth-century Hrómundar saga Greipssonar was first edited and translated into Latin and Swedish in Nordiska kämpa dater i en sagoflock samlade om forna kongar och hjältar... (Björner 1737) and it appears in this form in all modern compilations of the legendary sagas (Guðni Jónsson 1954; Valdimar Ásmundarson 1886; Rafn 18291830). The saga was most likely written by Jón Eggertsson at the end of the seventeenth century (Jucknies 2005, 2009; Kapitan 2018, 2021, there further references). The generally accepted interpretation of the relationships between the seventeenth-century saga and the rímur has been presented by Andrews (1911, 1912, 1913), Brown (1946-1953), and Jesch (1984). Recent scholarship has shown that at least one more saga of Hrómundur exists, which is most likely a nineteenth-century adaptation (Kapitan 2018, forthcoming).

${ }^{7}$ For further discussion of the wedding feast see works by, for example, Foote (1953-1957) and Úlfar Bragason (1994). Note the differences in the patronymic: some versions of the story refer to Hrómundur as Gripsson (e.g. Griplur) while others as Greipsson (e.g. the seventeenth-century Hrómundar saga Greipssonar).
} 
Tab. 1. Manuscripts of Griplur

\begin{tabular}{llll}
\hline Abbreviation & Shelfmark & Repository & Date \\
\hline C42 & $\begin{array}{l}\text { Cod. Guelf. 42.7. } \\
\text { Aug. 4to }\end{array}$ & Wolfenbüttel, Herzog August Bibliothek & 1480-1490 \\
A610 & AM 610 c 4to & Reykjavík, Stofnun Árna Magnússonar & 1610-1648 \\
A146 & AM 146 a 8vo & Reykjavík, Stofnun Árna Magnússonar & $1633-1700$ \\
Acc22 & AM Acc. 22 & Reykjavík, Stofnun Árna Magnússonar & ca. 1695 \\
L1370 & Lbs 1370 8vo & Reykjavík, Landsbókasafn Íslands & $1700-1800$ \\
A387 & AM 387 a-c fol. & Reykjavík, Stofnun Árna Magnússonar & 1849 \\
J55 & JS 55 4to & Reykjavík, Landsbókasafn Íslands & ca. 1870 \\
\hline
\end{tabular}

only a limited number of witnesses have been the subject of scholarly investigation so far.

Griplur or their fragments are preserved in seven known manuscripts, all but one of which are dated to the post-medieval period. They are all listed in chronological order in Table 1, which also includes abbreviations that will be used further in this article to refer to these manuscripts.

In addition to the seven listed manuscripts, there is one stanza from Griplur preserved in the margin of Reykjavík, Stofnun Árna Magnússonar, AM 151 4to, a fifteenth-century law manuscript, which contains numerous younger marginalia. Among them, on f. 80v, there is the stanza from Griplur, which was most likely written in the seventeenth century (Kålund 1889-1894: I:434). Due to its brevity it will not be analyzed in the present study.

There were at least four more manuscripts containing rímur about Hrómundur, most likely Griplur, in circulation in the late seventeenth century and the early eighteenth century, but today either Griplur are lost from these manuscripts or the entire volumes are lost.

The earliest known reference to a volume containing rímur of Hrómundur can be found in the list of manuscripts obtained by Jón Eggertsson in Iceland in 1682 (Klemming 1880-1882: 42). This manuscript contained six sets of rímur: Rímur af Remundi Rígardssyni, Rímur af Vilhjálmi sjóo, Egils rímur Skallagrímssonar, Hrómundar rímur, Ölvis rimur sterka, and Skotlandsrimur. The manuscript was most likely sent to Stockholm and is now lost, but elsewhere I have presented a hypothesis that the known prose version of Hrómundar saga may be based directly on this lost manuscript of rimur (Kapitan 2021). Another mention of 
Griplur appears in the list of the manuscripts in possession of Páll Vídalín (1667-1727). Among the collection of books from Vigur in quarto, there was a thick book in which Hrómundar rímur were the first item ("Onnur pyck Rimnabök. Pær fyrstu af Hröm(unde) Greipss(yne)”, Jón Helgason 1985: 19). Unfortunately, we do not know which other texts appeared in this manuscript, so it is impossible to identify the volume. None of the known extant manuscripts contains Griplur as the first item in the codex, so we have to assume that this manuscript is also lost. ${ }^{8}$

Another mention of a manuscript containing Griplur appears in Jón Ólafsson's catalogue of manuscripts in the Arnamagnæan Collection. According to Jón Ólafsson, AM 603 4to (A603), a sixteenth-century collection of various rimur held today in Stofnun Árna Magnússonar in Reykjavík, used to preserve Griplur, but this part of the manuscript has been lost (Kålund 1889-1894: II:4). ${ }^{9}$ Finally, in Bjarni Halldórsson's (1703-1773) collection of manuscripts there used to be a book in octavo, which does not seem to have survived either, but which contained various sets of rímur: "Apollónii rímur" (probably Rímur af Apollónius), Hálfdánar rímur Eysteinssonar, Króka-Refs rímur, Hrómundar rímur, and Andra rímur (Jón Helgason 1985: 38).

Leaving aside the lost manuscripts, it has to be noted that only a few of the extant manuscripts have been the subject of academic discussion. The relationships among most of them is mostly unknown or uncertain, as scholars have proposed competing interpretations.

The earliest published study of Griplur was conducted by Kölbing (1876: 159-60), who listed only three manuscripts that contain Griplur: The first one is "A. M. chart. 110c (= a), p. 71-98", which must be AM 610 c 4to (A610), preserving Griplur on ff. 71-98. The second one is "Cod. Guelf. Aug. 42, 4o (= b), fol. 62-66", which is Cod. Guelf. 42.7. Aug. 4to (C42), preserving Griplur on ff. 62-66. The third one is "A. M. chart. $145 \mathrm{a} .2 \mathrm{o}(=\mathrm{c})$ p. 283-86", which must be AM 146 a 8vo (A146),

\footnotetext{
${ }^{8}$ It cannot be excluded that the order of texts has changed in some known manuscript moving Griplur from the opening position further into the volume. Acc22 would be a possible candidate, as it is in quarto format, has significant thickness to be called "byck Rimnabök", and can be associated with the scribal milieu of Vigur. I did not have a chance to study the quire structure of this manuscript in order to confirm this hypothesis.

${ }^{9}$ Jón Ólafsson's catalogue is preserved, for example, in AM 477 fol., where on f. 41v AM 603 4to is described as containing Griplur. In my PhD thesis I devoted one section to the evaluation of the preservation history of AM 603 4to, but I was not able to establish when exactly Griplur were lost from this manuscript. It is not unlikely that it happened in the middle of the nineteenth century (Kapitan 2018: 164-167).
} 
preserving Griplur on pp.383-386. Shortly after that, Griplur were edited by Finnur Jónsson and published first in 1896 and in slightly revised form in 1905-1922. The only manuscripts that were used in these editions were A610, A146, and A387 (used as a reliable copy of C42), but in Rimnasafn Acc22 was also used in the variant apparatus (Finnur Jónsson 1896, 1905-1922). Around the same time, Albert LeRoy Andrews published his analysis of the saga and rimur of Hrómundur. He based his analysis on Finnur Jónsson's edition of Griplur from 1896, with only sparse reference to Rimnasafn, resulting in a rather superficial treatment of Acc22. The state of scholarship leaves us with one manuscript that has not been sufficiently studied (Acc22) and three manuscripts which have never been a subject of scholarly investigation (J55, A387, and L1370).

Given the state of the scholarship on rimur in general, it is perhaps not really surprising that there is no in-depth study of the transmission of Griplur, but given the discussion of the relationship between the lost saga of Hrómundur (*Hrómundar saga Gripssonar) and the rímur, and between the rimur and its seventeenth-century adaptation (Hrómundar saga Greipssonar), it seems unsatisfactory that the existing argumentation relies on incomplete evidence. Moreover, in the light of the recent discovery of a younger Hrómundar saga Greipssonar (Kapitan 2018, forthcoming), the transmission history of rimur becomes an especially important subject of investigation. It can deliver evidence for the identification of the sources of the younger saga and shed light on the history of adaptation of the story of Hrómundur in rímur and saga forms.

The present article is the first study of the transmission history of the medieval rimur of Hrómundur, which survive in only one medieval manuscript and a series of post-medieval ones, as illustrated in Table 1. The present study examines all known manuscripts preserving Griplur with the main focus on the previously ignored manuscripts. It aims to reveal the textual relationships between them and establish a complete stemma of this tradition. The complete stemma can not only serve as a basis for a new text-critical edition of this work, but can also shed light on the transmission and adaptation history of the story of Hrómundur in prose and verse. The article consists of three main parts. The first part is devoted to the contents of the rimur; it identifies the rhyming schemes and meters in which the various fitts are written and summarizes the main events described in each fitt. The second part consists of descriptions of the extant manuscripts with the main focus on the contents of these manuscripts and their scribal milieu. The third part examines the relationships between the 
texts of Griplur that these manuscripts preserve; it compares the order of stanzas and textual variation and discusses the similarities and differences between them.

\section{The story of Hrómundur in Griplur}

The contents of the rimur correspond fairly closely to the contents of the seventeenth-century Hrómundar saga Greipssonar, but it is worth mentioning that the chapter division of the saga known from modern editions does not correspond to the division into fitts of Griplur. This is not surprising in the context of rimur tradition, where poets try to keep their audience in suspense. Therefore, rimur frequently abruptly end in the middle of some exciting event. This can be exemplified by the first battle of the story, which is divided between the first and the second rima.

The first rima consists of 67 stanzas written in ferskeytt meter with four lines rhyming $a b a b .{ }^{10}$ In this rima the main characters are introduced: first Ólafur, the king of Hörðaland in Norway, and his followers Kári and Örnúlfur; then Gripur and his wife Gunnlöð and their sons, including Hrómundur; then finally the evil brothers, Vóli and Bildur. One day Ólafur sets off for a raiding trip and stops by Elfarsker, where a battle with Hröngviður takes place. During the battle both Kári and Örnúlfur are killed by Hröngviður, but Hröngviður is killed by Hrómundur by the end of the ríma.

The second rima consists of 62 stanzas written in braghent meter with three lines rhyming aaa. In this ríma Hrómundur finds Helgi the famous, Hröngviður's brother, and heals him, even though Helgi promises to avenge his brother's death. Afterwards Ólafur and his army raid an island on which a certain Máni is living. They learn from him about the king Práinn and his treasures and get directions how to find Práinn's burial mound. They sail south for six days until they reach the land where the burial mound is located and after four days they manage to break into the mound. Hrómundur enters the mound, when no one else is courageous enough to do it.

\footnotetext{
${ }^{10}$ The identification of meters in this section follows the discussion of Griplur published by Björn K. Pórólfsson (1934: 353). A concise overview of various rímur meters has been presented by Hughes (1982: 404-405), while a more detailed discussion has been presented by Helgi Sigurðsson (1891).
} 
The third rima consists of 64 stanzas written in ferskeytt meter. In this ríma Hrómundur fights with Práinn and after a long fight he kills Práinn and steals his treasure, including the ring, necklace, and sword Mistilteinn. When Hrómundur comes out of the mound, Ólafur and his army head back to Björgvinland in Norway.

The fourth rima consists of 64 stanzas written in stafhent meter with four lines rhyming aabb. In this ríma Hrómundur receives a dog, named Hrókur, from a man called Grundi, but Vóli kills Hrókur shortly afterwards. This is one of the episodes which are corrupted in the seventeenthcentury adaptation of the story, as Hrókur in the saga is a man rather than a dog (see Brown 1946-1953; Jesch 1984). Here Ólafur's sisters, Svanhvít and Dagný, are also introduced. Hrómundur and Svanhvít see each other frequently, and the evil brothers plot against Hrómundur, forcing Hrómundur to leave the kingdom and stay with his father. Meanwhile, two Swedish kings, both called Haddingur, challenge Ólafur to a battle on the frozen lake Vænir. Ólafur asks Hrómundur to join his army, but Hrómundur rejects the invitation until Svanhvít convinces him to go. Svanhvít gives him a shield which is supposed to protect him. When Hrómundur and his brothers arrive on the battlefield, Bildur has already been killed and Ólafur has killed one of the Swedish kings. The following day Hrómundur refuses to go to the battle, because he has had a bad dream, but his brothers decide to go anyway. Helgi, Hröngviður's brother, is in the battle, accompanied by his mistress Kára, who is flying over the battlefield in a shape of a swan and uttering magic howls which make men defenseless. Thanks to her help, Helgi kills Hrómundur's brothers. When Hrómundur finds out about this, he fights Helgi and eventually kills him, after Helgi unwillingly killed Kára.

The fifth rima consists of 51 stanzas written in ferskeytt oddhent meter with four lines rhyming $a b a b$, with additional internal rhyme in the first and third line. In this ríma Hrómundur fights Vóli and kills him, but loses his sword. Svanhvít and her sister come to heal Hrómundur and sew his wounds. Afterwards Hagall and his wife take care of Hrómundur. Hagall finds Hrómundur's sword inside a fish he catches one day and returns it to Hrómundur. Meanwhile Haddingur finds out from Blindur that Hrómundur is hiding in his kingdom and sends Blindur to find Hrómundur. Blindur cannot find Hrómundur because Hagall and his wife first hide him under a big pot and then dress him as a female servant.

The sixth rima consists of 58 stanzas written in ferskeytt meter. In this ríma Blindur tells Haddingur his dreams and the king misinterprets their 
meaning. Meanwhile Hrómundur is fully healed at Hagall's place and, when Ólafur with his army is raiding Sweden, Hrómundur joins him and kills Haddingur, in revenge for the death of his brothers. Afterwards Blindur, whose name is now revealed as Bölvis, is hanged, and Hrómundur marries Svanhvít and they found a royal line.

\section{The manuscripts}

\subsection{Wolfenbüttel, Cod. Guelf. 42.7. Aug. 4to}

Cod. Guelf. 42.7. Aug. 4to (C42) is a parchment manuscript held in the Herzog August Bibliothek in Wolfenbüttel, Germany (von Heinemann 1966: 23). It contains exclusively rimur, some of which are defective. According to Ólafur Halldórsson, C42 used to preserve twenty sets of rímur, but four of them are lost (Ólafur Halldórsson 1968: xii-xv). The remaining sixteen texts appear in the following order: Sigurðar rímur fóts, Skikkju rímur, Ormars rímur Framarssonar, Áns rímur bogsveigis, Hrings rímur og Tryggva, Geirarðs rímur, Konráðs rímur, Ólafs rímur Tryggvasonar, Griplur, Ektors rímur, Filipó rímur, Sálus rímur og Nikanórs, Herburts rímur, Geiplur, Grettis rímur, Mábilar rímur. Griplur are preserved on ff. 62r-66r but their text is defective. There is a lacuna through stanzas I:1-II:53, as the two first leaves of the gathering are missing. According to Ólafur Halldórsson, Griplur are written in two hands, but neither of them has been yet identified in other manuscripts (Ólafur Halldórsson 1968: xi, xvi).

C42 can be dated to the late fifteenth century, but Ólafur Halldórsson (1968: xxxvj) narrowed down the dating of the manuscript to ca. 14801490. In Old Norse-Icelandic scholarship this manuscript is known as Kollsbók, named after its first owner Jón kollr Oddsson, a lögréttumaður from Holt in Saurbær in Dalasýsla, who lived at the turn of the fifteenth and sixteenth centuries. The history of C42 is well described in the introduction to the facsimile edition from 1968, so the reader is encouraged to seek further information there. What is important from the perspective of this study is, first, that C42 left Iceland before 1657-1666, when it was bought by Augustus II (1579-1666), the duke of Brunswick Lüneburg (Spehr 1875). It could therefore had served as an exemplar for other texts of Griplur until it left Iceland. Secondly, it is important that 
much later C42 was lent to Copenhagen, in the years 1849-1850, where it was copied by the Arnamagnæan stipendiaries. In the Antiquarisk tidsskrift for the years 1849-1851 we can read the announcement about the discovery of $\mathrm{C} 42$ and that the Arnamagnæan Commission, following Carl Christian Rafn's suggestion, made a copy of it.

Ved Etatsraad Rafns Foranstaltning blev hertil laant et [...] islandsk Haandskrift, indeholdende en Samling Rímur. Da Haandskriftet er paa Membran, og endda temmelig gammelt, har Commissionen ladet tage en Afskrift deraf ved Stipendiarerne. (Det Kongelige Nordiske Oldskriftselskab 1852: 7)

The copy mentioned in this note must be A387, as this manuscript preserves reliable transcripts of all the texts present in $\mathrm{C} 42$ with references to the loci in $\mathrm{C} 42$ (see the description of A387 below).

The readings of C42 for Griplur were used in Kölbing's (1876) discussion of the relationships between the manuscripts of Griplur, in both of Finnur Jónsson's (1896, 1905-1922) editions of Griplur, and consequently in Andrews' (1911) analysis. Finnur Jónsson, however, relied in both of his editions on the readings of A387, not C42 directly.

\subsection{Reykjavík, AM 610 c 4to}

AM 610 c 4to (A610), held at Stofnun Árna Magnússonar in Reykjavík, is a paper manuscript which consists of 159 leaves, paginated 1-317; leaf 159 verso is not paginated. A610 contains exclusively rímur, some of which are defective. The texts appear in the following order: Jarlmanns rímur, Griplur, Ólafs rímur Tryggvasonar, Hemings rímur Áslákssonar, Konráds rímur, Herburts rímur, Reinalds rímur, Andra rímur. A610 contains a complete text of Griplur, which is preserved on pp. 71-98. The text starts in the middle of p. 71 with a rubric which reads "hromundarrýmur", and each subsequent ríma is introduced with a similar rubric (pp. $76,80,85,90,94)$.

Kålund (1889-1894: II:15) dates the manuscript to the seventeenth century but based on the scribe's lifespan it can be narrowed down to ca. 1610-1648. A610 is written in one hand throughout, which has been identified as the hand of Jón Gissurarson (ca. 1590-1648), a lögréttumaður and a prolific scribe, from Núpur in Dýrafjörður (Björn K. Pórólfsson 1934: 11; Páll Eggert Ólason 1948-1952: III:118-119). Jón was a part of an active scribal network of seventeenth-century Iceland: he was a half-brother of Brynjólfur Sveinsson, bishop of Skálholt, who might have 
to some extent inspired Jón's antiquarian interests. ${ }^{11}$ A610 previously belonged to a bigger manuscript which consisted of AM $610 \mathrm{~b}-\mathrm{f} 4$ to, all preserving exclusively rímur (Stegmann 2016: 95, 327).

The readings of A610 for Griplur were used in Kölbing's study, both of Finnur Jónsson's editions, and Andrews' analysis. According to Björn K. Pórólfsson (1934: 1-121), some of the rímur preserved in AM 610 b-f 4to are derived from the parchment manuscripts AM 603 4to and AM 604 4to, while the exemplars of the others, including Griplur, are unknown.

\subsection{Reykjavík, AM 146 a 8vo}

AM 146 a 8vo (A146), held at Stofnun Árna Magnússonar in Reykjavík, is a small paper manuscript in octavo which consists of vii+217+i leaves, paginated 1-434. It contains exclusively rímur, many of them defective. The texts appear in the following order: Hálfdanar rímur Eysteinssonar, Gátu ríma, Andra rímur, Bjarka rímur, Bósa rímur, Hálfdanar rímur Brönufóstra, Barings rímur, Nitídu rímur fragu, Króka-Refs rímur, Ormars rímur Framarssonar, Skotlands rímur, Evu rímur, Jórsala rímur, Egils rímur einhenda, Rollants rímur, Póris rímur háleggs, Hrólfs rímur Gautrekssonar, Vilmundar rímur viðutan, Skógar-Krists rímur, Griplur, Konráðs rímur, Valdimars rímur frakna, Appolóníus rímur, Rímur af barndómi Jesú Krists. Griplur are preserved on pp. 383-386 and the text is defective. There is a large lacuna from stanza I:37 to VI:36. The text starts with a rubric "Hier Byriar Hromundar Rijmur." on p. 383 and continues to p. 384 (the verso side of the same leaf), and then it starts on p. 385 with an incipit "Ødling vaknar ekkj fir enn vte fra eg hann liggia" and continues to p. 386 where the next set of the rimur starts immediately after. In the margins of A146 there are notes in Jón Sigurðsson's hand which specify that there is a lacuna in the text and identify to which rima the stanzas belong.

In Kålund's catalogue the manuscript is dated to the first half of the seventeenth century (Kålund 1889-1894: II:411-412) but, as Björn K. Pórólfsson observed, A146 has to be younger than AM 145 8vo, which is also written by the same scribe and contains the date of 1633 associated with the ownership note. Moreover, the last set of rimur preserved in this manuscript was composed in 1656 , excluding the possibility that the

\footnotetext{
${ }^{11}$ On Jón Gissurarson's scribal activity and his scribal network see, for example, Springborg
} (1977: 78-80) and Lansing (2011: 61). 
manuscript was completed in the first half of the seventeenth century. A146 is written in one hand throughout, which has been identified as the hand of Jón Finnsson from Flatey in Breiðafjörður, but the lifespan of the scribe is uncertain. Árni Magnússon received this manuscript in 1703 from Loftur Jónsson from Flatey.

The readings of A146 for Griplur were used in Kölbing's study, Finnur Jónsson's editions, and consequently in Andrews' analysis. According to Björn K. Pórólfsson (1934: 10), Ormars rímur Framarssonar and Konráds rimur in A146 are derived from C42. There is therefore a possibility that Griplur in A146 may be also derived from C42.

\subsection{Reykjavík, AM Acc. 22}

AM Acc. 22 (Acc22), held at Stofnun Árna Magnússonar in Reykjavík, is a paper manuscript in quarto format which consists of 311 leaves. The manuscript was rebound in 1963 and divided into three volumes: I: i + $85+$ iv (notes) + i (paginated 1-170); II: i $+112+$ vi (notes) $+i$ (paginated 171-394); III: i + 114 + ii (notes) + i (paginated 395-622). The manuscript preserves exclusively rimur, some of which are defective. The texts appear in the following order: Rollants rimur, Viktors rimur og Blávuss, Rímur af Illt, Verra og Verst, Dínus rímur, Reinalds rímur, Hrings rímur og Tryggva, Gríms rímur jarlssonar, Haralds rímur Hringsbana, Úlfhamsrímur, Skikkju rímur, Griplur, Landrés rímur, Áns rímur bogsveigis, Jarlmanns rímur, Ólafs rímur Tryggvasonar, Geiplur. Griplur are preserved in the third volume on pp. 395-428. They start with a rubric "R̈̈mur af Hrömunde Grelÿps syne I fyrsta Rijma". Each subsequent rima is introduced with a smaller rubric (pp. 402, 407, 413, 418, 423).

The manuscript can be dated to the last decade of the seventeenth century, as the date 1695 is attested in multiple places in the manuscript. For example, Griplur end on p. 428 with a colophon which reads "Endadar pessar Rymur ad Oos hlijd Anno 1695 in Aprilis". The same year can be found in colophons on pp. 322, 374, 483, and 532. ${ }^{12}$ Acc22 is written in two hands. The main hand is the one of Jón Pórðarson, one of the scribes of Magnús Jónsson from Vigur. Jón Pórðarson wrote pp. 1-532, including Griplur, and the colophons on pp. 428 and 532 suggest that he wrote at

\footnotetext{
${ }^{12}$ The manuscript was catalogued in 2001 by Matthew Driscoll for the online catalogue Handrit.is.
} 
least some parts of the manuscript around Óshlíð near Bolungarvík in the northwest part of the Westfjords. A second unidentified hand wrote pp. 533-621. The manuscript was acquired by the Arnamagnæan Collection in 1902, after a recommendation from Finnur Jónsson, in which he expressed his belief that the texts of Skikkju rimur and Griplur are especially valuable. ${ }^{13}$ It is intriguing that, even though Finnur Jónsson thought that the text of Griplur in Acc 22 was especially valuable, this manuscript has not received much scholarly attention and Finnur himself used it only to a very limited extent.

The readings of Acc22 for Griplur were used only in the variant apparatus of Finnur Jónsson's Rímnasafn, and briefly mentioned by Andrews, who believed that Acc22 represented a fourth branch of the oral tradition of Griplur. Some of the texts preserved in Acc22 are derived from AM 604 4to and A603, while the exemplars of the others, including Griplur, are unknown (Björn K. Pórólfsson 1934: 12-13).

\subsection{Reykjavík, Lbs 1370 8vo}

Lbs 1370 8vo (L1370), held at Landsbókasafn Íslands in Reykjavík, is a paper manuscript which consists of 305 leaves. The manuscript contains mainly fragments of rimur and other poems, as well as a fragment of Grettis saga and a fragment of Helenu saga. The texts appear in the following order: Andra rímur, Griplur, Nitídu rímur fragu, Sigurgarðs rímur, Eiríks rímur víðförla, Grettis saga, various poems, Hálfdanar rímur Eysteinssonar, Jóhönnuraunir, Esópus rímur, Sigurðar rímur snarfara, Sigurðar rímur pögla, Sigurgarðs rímur og Valbrands, Helenu saga. Griplur occupy ff. $18 \mathrm{r}-27 \mathrm{r}$ and their text is defective, as clearly visible on Figure 1. There are three big lacunas in the text, which correspond to the following stanzas in Rímnasafn: I:1-I:56 (ca. 56 stanzas), II:18-III:3 (ca. 44 stanzas), III:29-IV:15 (ca. 50 stanzas). The beginning of the rimur is missing, so it is unknown what rubric introduced the rimur, but the subsequent fitts are introduced by small rubrics which can be found on ff. 18r, 22r, and 24r.

According to Páll Eggert Ólason (1918-1937: II:267), the manuscript was written mainly in the eighteenth century in several unidenti-

\footnotetext{
${ }^{13}$ Finnur Jónsson's recommendation can be found at the Arnamagnæan Institute in Copenhagen, in the collection of the Arnamagnæan Commission's correspondence. The letter is dated to 7 June 1902.
} 


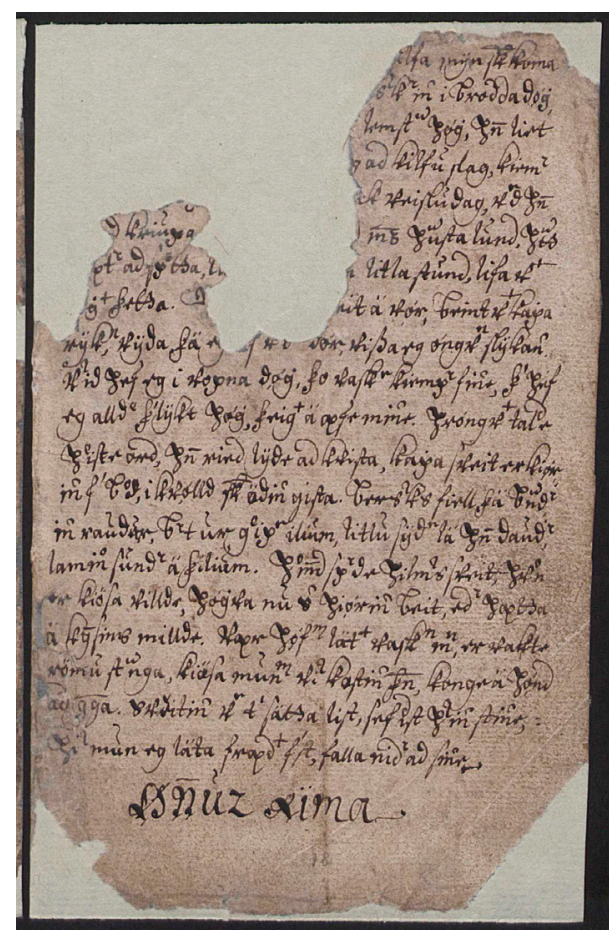

Fig. 1. The first leaf of Griplur in Lbs 1370 8vo, f. 18r. Photo by courtesy of Landsbókasafn Íslands in Reykjavík.

fied hands, but one part of the manuscript, that containing Esópus rímur, can be dated to the seventeenth century. There is a number of names and notes that appear in the manuscript, such as: "Jon Thorarins Son" (f. 27r), "SigurdurGudmundssSon" (f. 93v), "Thorunn Gudmunds Dott[ir] aa Rimuenar [sic]" (f. 136v), "Biorn BiarnaSon", "Gudmund[00]", and "Magnus BiornsSon" (f. 215v), but none of these have yet been identified. The manuscript was purchased by Landsbókasafn Íslands in 1906 as a part of a larger collection of manuscripts which had previously belonged to Jónatan Porláksson (1825-1906), a lay scholar and book collector from Pórðarstaðir in Fnjóskadalur in Northern Iceland.

The readings of Griplur from L1370 have not yet been used in any known study, and the position of this text in the stemma has remained unknown to this point. The relationships between L1370 and the remaining manuscripts are discussed further in this article where a stemma for the entire tradition of Griplur is proposed. 
AM 387 a-c fol. (A387), held at Stofnun Árna Magnússonar in Reykjavík, is a paper manuscript in three volumes: Volume I: i+ii+133+i+ii (foliated 1-133); Volume II: i+ii+142+ii+ii (foliated 134-275); Volume III: i+ii+191+ii+ii (foliated 276-466); which together consist of 466 leaves foliated in red ink in the upper margins. The volumes contain the following texts: Sigurðar rímur fóts, Skikkju rímur, Ormars rímur Framarssonar, Áns rímur bogsveigis, Hrings rímur og Tryggva (Volume I); Geirarðs rímur, Konrádsrímur, Ólafs rímur Tryggvasonar, Hrómundar rímur (Griplur), Ektors rímur (Volume II); Filipó rímur, Sálus rímur og Nikanórs, Herburts rímur, Geiplur, Grettis rímur, Mábilar rímur (Volume III).

A387 is a scholarly transcript of the texts preserved in C42 and all the texts appear in the same order in both manuscripts. Griplur are preserved on ff. 211r-228r and they start with a note, which reads "[Hrómúndar rímur Gripssonar] I vantar framan við. - I II. ríma. 54 I erindi I AM 610c 4to." Moreover, in the margin there is a note, "Bls 62a," which refers to the location of Griplur in C42.

According to Kålund (1889-1894: I:302), the manuscript is written in various hands and was copied in $1849 .{ }^{14}$ Even though Kålund does not name the scribes, it is possible to establish that primarily three people were involved in the production of this manuscript. First of all, from the announcement in the Antiquarisk tidsskrift for years 1849-1851, which has already been cited above in the description of $\mathrm{C} 42$, we learn that the Arnamagnæan stipendiaries were responsible for preparing the transcriptions. According to Finnur Jónsson (1896: iii), Gísli Brynjúlfsson (sometimes referred to as Brynjólfsson) (1827-1888) was responsible for the copy of Völsunga rímur in A387. This reference to Völsunga rímur, however, must be a mistake and Finnur Jónsson must have meant Griplur, as neither C42 nor A387 contain Völsunga rímur. Moreover, it is clear from the context of this reference that Finnur Jónsson (1896: iii) meant Griplur, as he wrote:

Griplur eru til í heilu líki aðeins í einu handriti, $6104^{\circ}$ í Árnasafni [...] Par næst eru rímurnar í rímnabókinni í Wolfenbüttel (W); er til afskrift af henni í 3 bindum

\footnotetext{
${ }^{14}$ According to Kålund the volumes had titles on their spines "Rimnabók I-III," but this is not the case anymore, as the manuscript was rebound in 1993, when the, probably, original leather and yellow-shiny-paper cover was replaced by a leather and canvas cover. The photographs of the first volume from before and after re-binding are available at the Arnamagnæan Institute in Copenhagen.
} 
í Árnasafni 387, 2; Völs.r. eru í 2. bindinu, ritaðar af Gísla Brynjólfssyni, og er pað mein við pá uppskrift, að stafsetníngu skinnbókarinnar er ekki fylgt.

Björn K. Pórólfsson (1934: 4), when discussing C42, states that he could not use the parchment manuscript itself, but a copy by Jón Sigurðsson and others in A387 ("hef jeg ekki getað notað skinnbókina sjálfa, heldur uppskrift Jóns Sigurðssonar og annara í AM 387 fol.”). Therefore, it is possible that Jón Sigurðsson was also involved in the copying process of A387. Ólafur Halldórsson (1968: xxxix) states that A387 was copied by Jón Sigurðsson, Gísli Brynjúlfsson, and probably Brynjólfur Snorrason. All three men held the Arnamagnæan stipend at least once: Jón Sigurðsson in 1835-38 and 1838-48, Brynjólfur Snorrason in 1848-50, and Gísli Brynjúlfsson in 1848-50 and 1850-77. Only Gísli, however, mentions copying C42 in his reports as a stipendiary. In Gísli's report for 1849, dated to 15 March 1850, he states that he was responsible for copying a number of texts from $\mathrm{C} 42$, which were borrowed by the Commission to Copenhagen, including Hrómundar rímur. This is certainly A387 that he copied, as the texts he listed in the report appear in the same order as the contents of the second volume of the collection and the first item in the third volume. In another report from 18 February 1851, for the year 1850, Gísli wrote that he checked his transcription of rimur "med Secretaren" (with the secretary). Jón Sigurðsson was appointed a secretary of the Arnamagnæan Commission in 1848, so it is likely that he acted as a project supervisor and checked Gísli's transcriptions in 1850 (Finnur Jónsson 1930: 222-228; Katrín Jakobsdóttir et al. 2011). There are indeed some marginal notes in A387, which are probably Jón Sigurðsson's corrections of Gísli's transcriptions.

The readings of A387 have been extensively used in the literature, but not in their own right, rather only as the readings of $\mathrm{C} 42$.

\subsection{Reykjavík, JS 55 4to}

JS 55 4to (J55), held at Landsbókasafn Íslands in Reykjavík, is a paper manuscript which consists of 153 leaves and a number of loose leaves, 175 leaves in total (Páll Eggert Ólason 1918-1937: II:500). The manuscript is written in three hands, with the hand of Jón Sigurðsson being the main one. J55 preserves mostly rímur and rímur-related material, in the following order: Barings rímur, Hrings rímur og Tryggva, Geiplur, Griplur, Ólafs rímur Haraldssonar, Vilhjálms rímur sjóðs, Flóres rímur og sona 
hans, Virgiles rímur, Póris rímur háleggs, notes on and excerpts from various rímur, a letter from Eggert Briem, and a register of rimur and other poems.

Griplur are preserved on ff. $45 \mathrm{r}-89 \mathrm{v}$, and f. $45 \mathrm{r}$ serves as a title page for the rimur, with an enlarged title written in blue crayon. The verso side of this leaf is blank, and on the recto side of the following leaf (f. 45bis) there is a note: "rhytmo quodam de Tumulo cola Thraino I Eg hefi lengi lumað á fé I og lifað í haugi mínum I eigi er gott, pótt góđir sé, I gripum at treysta sínum. I JOlGrv. Add. 8. 4to p. 2753. I (NB úr 'Griplum' ?)". The stanza included in this note corresponds to Griplur III:50, and it was probably copied from Jón Ólafsson's dictionary Contractismus seu lexicon contractionum vocum Islandicarum, preserved, among other places, in AM 979 c 4to. On f. 346r of AM 979 c 4to there is a verb, "at luma á nockru", with the same stanza used as an example of the word's use. No source of the stanza, however, is given in the dictionary, and none of the known manuscripts of Griplur preserve it in exactly the same form. The variation, however, appears only in the first line of the stanza, so it is not certain if this stanza was a part of another tradition of the rimur or whether it is a result of Jón writing it down from memory.

J55 is a scholarly manuscript with extensive marginal notes which focus on corrupted readings, page breaks of the exemplar, and other existing copies of rimur. For example, on f. $49 \mathrm{v}$ by stanza I:36 there is a marginal note, which reads "hér hættir brotið í AM 146. 8vo og er héðan frá tekið eptir 610". On f. 59r by stanza II:54 there is another marginal note, which reads: "hér tekur til rímnabókin frá Wolfenbüttel (mín), Tom. II, pag. 153". It is worth emphasizing that Jón Sigurðsson uses the expression "my vol. 2" when referring to C42. Since he was involved in the preparing the transcript of $\mathrm{C} 42$ in $\mathrm{A} 387$, this reference must be to the second volume of A387, where Griplur starts on p. 153.

The readings of J55 follow the exemplar very closely, and, due to their scholarly character, they do not contribute much to our understanding of the transmission of rimur and their relationship to the saga. There is, however, a marginal note on $\mathrm{f}$. 46r which gives an insight into the early scholarship on this matter. There are references to Rafn's edition of the saga as well as to the account of Sturlunga about Hrómundur. Moreover, at the end of the note we read that "Getið um vísur í sögunni sem pessar I rímur eru ortar eptir I sjá I,30.39. IV,7.", which suggests that the scribe was interested in the sources of rimur and the lost medieval *Hrómundar saga, which must had contained some verses that have not survived. 


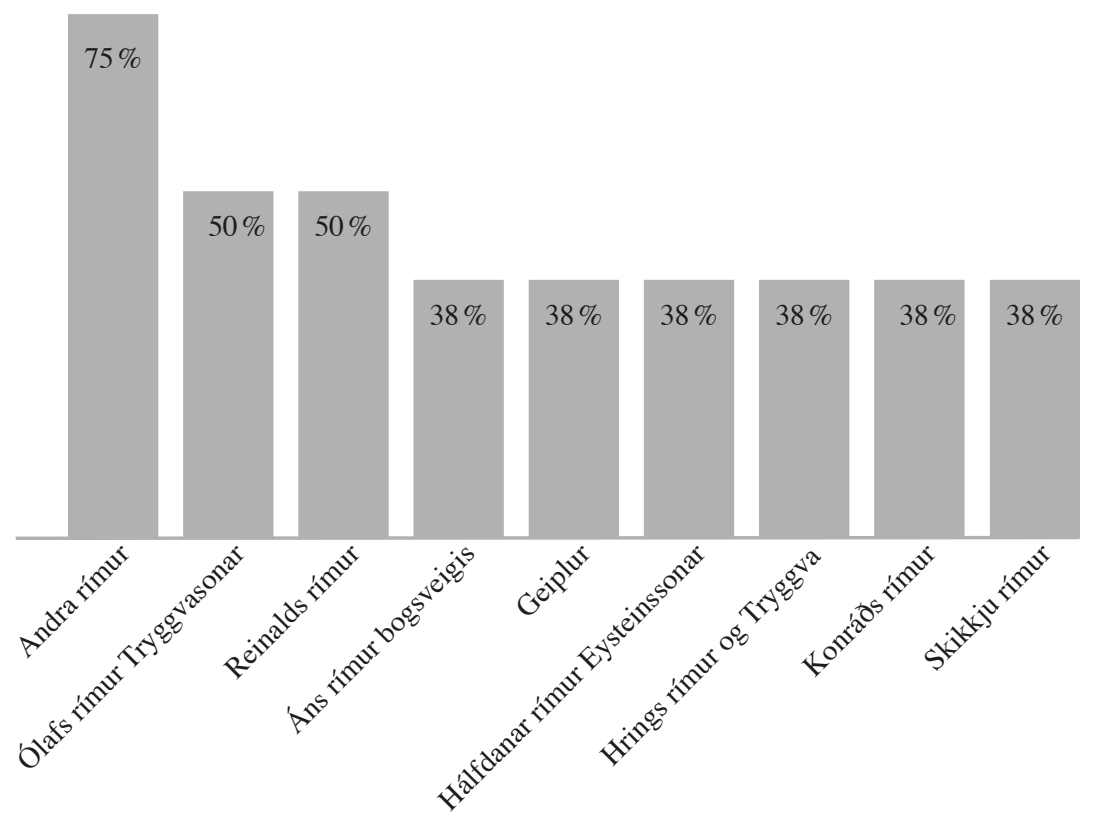

Fig. 2. Texts frequently co-occurring with Griplur including lost texts of extant manuscripts and known contents of lost manuscripts.

The evidence of J55, with the scholarly marginalia including some of the variants, suggests that the manuscript could have been prepared as a draft for a printed edition of rimur. It can be noted that the work was rather advanced, as J55 contains also other scholarly transcripts of rímur, including for example Ólafs rímur Haraldssonar and Geiplur. Jón Sigurðsson died in 1879 without completing this possible enterprise of publication of this collection of rimur, and it cannot be excluded that Finnur Jónsson was building on Jón's work while preparing his editions. J55 is not, however, mentioned directly in any of Finnur's works.

\subsection{Manuscript context of Griplur}

The manuscript descriptions presented in the previous sections demonstrate that the textual context in which Griplur appear is very diverse. If we focus only on the non-scholarly manuscripts, and thereby exclude J55 and A387, there are over sixty different sets of rimur which co-occur with Griplur. They vary remarkably in their subject matter, from rimur with theological or religious references, such as Rímur af barndómi Jesú Krists, through 


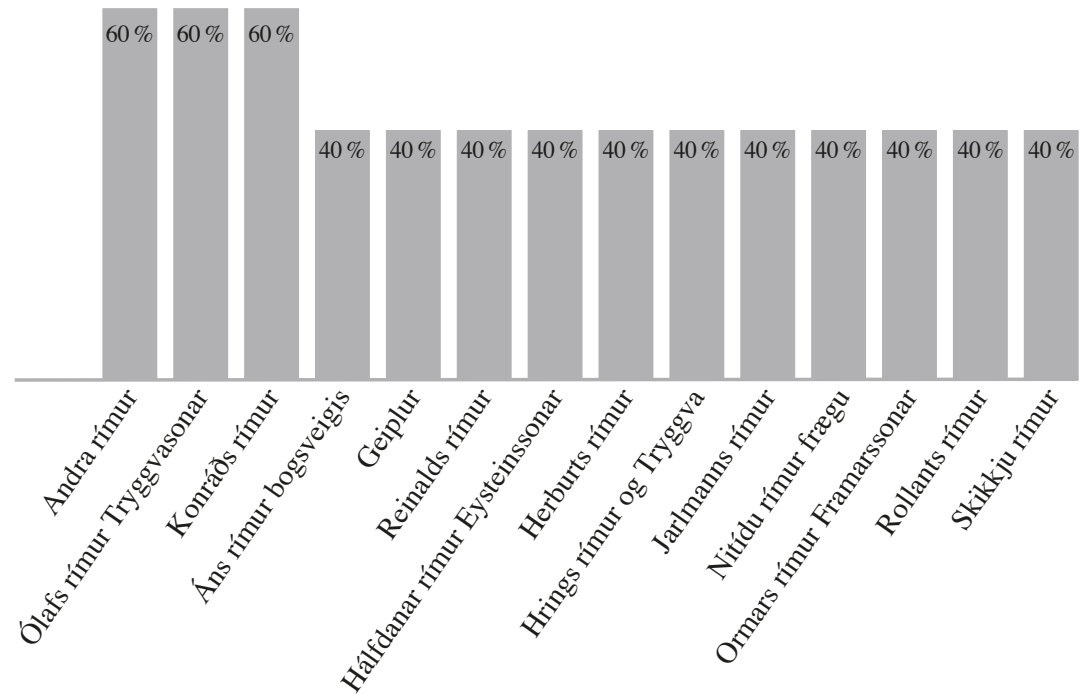

Fig. 3. Texts frequently co-occurring with Griplur in extant manuscripts, excluding lost texts.

riddarasögur-and fornaldarsögur-related rímur, such as Konráds rímur and Hálfdanar rímur Brönufóstra, to Íslendingasögur-related material, such as Króka-Refs rímur. As illustrated in Figures 2 and 3 the most frequently cooccurring sets of rimur are related to chivalric and legendary sagas. Figure 2 presents the texts which appear together with Griplur more than twice, and is based on an analysis of all known contents of the lost manuscripts which once preserved Griplur as well as the lost rimur from C42. Figure 3 presents the texts which appear together with Griplur more than once, but it is based exclusively on the contents of the extant manuscripts in their current form. In both cases two sets of rimur appear alongside Griplur most frequently, Andra rímur and Ólafs rímur Tryggvasonar, with Andra rímur taking the lead when we consider the contents of all known lost manuscripts.

The co-occurrence of Andra rimur with Griplur is not surprising. Andra rimur is another example of rimur based on a lost fornaldarsaga, and if we take into consideration the extensive literary borrowings appearing in Griplur and Andra rimur, as well as their similar adaptation history, we can understand why these two texts frequently co-occurred in the manuscripts. The story of Andri, like the story of Hrómundur, exists in two metrical adaptations, one from the Middle Ages and one from the nineteenth century, and at least in two prose adaptations, one of which was 
printed in 1895 as Saga af Andra jarli, Helga hinum prúða og Högna Hjarandasyni (Björn K. Pórólfsson 1934: 422-4; Simek and Hermann Pálsson 1987: 12; Finnur Sigmundsson 1966: I:34-5).

The frequent co-occurrence with Ólafs rímur Tryggvasonar is more challenging to explain. They appear together with Griplur in four manuscripts (or three if we exclude A603, from which Griplur are now lost), but it is not always the same rimur that appear alongside Griplur. There are two medieval sets of rímur about Ólafur Tryggvason, which in Rímnasafn are called Ólafsrímur A and Ólafsrímur B. Ólafsrímur A are Ólafs rímur Tryggvasonar af Indriða patti ilbreiðs, following Björn K. Pórólfsson's references, while Ólafsrímur B are Ólafs rímur Tryggvasonar af Svöldrarorustu. In three manuscripts both sets of rimur appear one after another (A603, A610, and Acc22) but in one (C42) only Ólafs rímur Tryggvasonar af Svöldrarorustu are preserved. This makes Ólafs rímur Tryggvasonar af Svöldrarorustu the second most frequently co-occurring text with Griplur. According to Björn K. Pórólfsson (1934: 333-335), Ólafs rímur Tryggvasonar af Svöldrarorustu are based mainly on Oddur Snorrason's Ólafs saga Tryggvasonar..$^{15}$ The subject matter treated in these rimur also appears in younger adaptations: Rímur af Svoldar orustu by Jón Bjarnason, composed in 1742, and Rimur af Svoldar Bardaga by Sigurður Breiðfjörð, composed in 1824. These adaptations, however, are hardly ever seen as a part of the same tradition as Oddur's Ólafs saga Tryggvasonar and related material.

What these three sets of rimur have in common is presumed authorship, as all of them have been traditionally attributed to Sigurdur the blind, a poet who is believed to have lived at the turn of the fifteenth and sixteenth centuries (Jón Porkelsson 1888: 277-303). It may be significant that Áns rímur bogsveigis and Reinalds rímur, each frequently appearing alongside Griplur, were also attributed to Sigurður. Björn K. Pórólfsson (1934: 437-440) excludes, however, the possibility that Griplur and Ólafs rímur Tryggvasonar af Svöldrarorustu were composed by Sigurður, as he considers them to be older than Sigurður's lifespan. Also, according to the rimur-chronology developed by Haukur Porgeirsson (2013), these sets of rímur are not contemporary: Griplur are dated to 1350-1400 while Ólafs rímur Tryggvasonar af Indriða patti ilbreiðs are dated to 1400-1450,

\footnotetext{
${ }^{15}$ Oddur Snorrason's Ólafs saga Tryggvasonar is a konungasaga known from a translation of Latin biography of king Ólafur Tryggvason composed around 1190 by a monk Oddur Snorrason, and is one of the oldest Icelandic sagas. The critical edition of the saga was published in 1932 (Simek and Hermann Pálsson 1987: 192-293).
} 
Ólafs rímur Tryggvasonar af Svöldrarorustu to 1450-1500, and Andra rímur to 1450-1500 and 1500-1550.

Taking into consideration the modern generic division of Icelandic literature, the co-occurrence of rímur based on a konungasaga, Ólafs rímur Tryggvasonar af Svöldrarorustu, together with a text presumably based on a lost fornaldarsaga, Griplur, is difficult to explain. We could speculate whether the king's name, Ólafur, could in the eyes of late medieval and post-medieval audiences establish a link between Griplur and Ólafs rímur, as Hrómundur is also in service of a king named Ólafur, but according to Griplur this Ólafur was a son of Gnóðar-Ásmundur, not of Tryggvi. Putting aside generic associations of these texts, they both can be thought of as re-workings of legendary narratives about great Norwegian heroes (this would also apply to Andra rimur). For the audiences of the fifteenth century and later periods the great battle of Svolder from 999/1000, described in Ólafs rímur Tryggvasonar af Svöldrarorustu, may have been equally legendary, equally true or fictitious, and equally entertaining, as the battles on Vänern and by Elfasker, described in Griplur. All these events were equally distant in time for the fifteenth-century audience, and it would be anachronistic to exclude the possibility that they were all treated as legends of the splendid past only on the basis of the modern reception of these works.

\section{The relationships between various texts of Griplur preserved in extant manuscripts}

\subsection{State of the scholarship}

As already mentioned in the introduction and in the previous section, the state of the scholarship on the relationships between the manuscripts of Griplur (or rather on the texts they preserve) is sparse. The majority of scholarly discussion has focused mainly on the relationship of the rimur to the seventeenth-century saga and the lost *Hrómundar saga, rather than on texts (or witnesses) of the rimur.

The first ever published classification of the witnesses of the rimur was presented by Kölbing in his Beiträge zur Vergleichenden Geschichte der Romantischen Poesie und Prosa des Mittelalters. There Kölbing compared only three manuscripts of the rimur, A610, A146, and C42, 


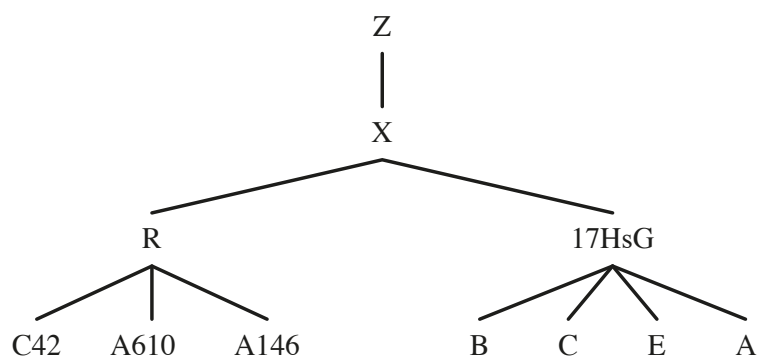

Fig. 4. Visualization of Kölbing's interpretation of the relationships among three witnesses of Griplur (C42, A610, A146), and the manuscripts of the saga $(17 \mathrm{HsG})$, which are irrelevant for the current discussion.

and considered all of them to be independent witnesses derived from a common original, which he called R. Kölbing believed that C42 was based on an oral account of the same "version" of the rímur as A610 and A146, which he traced back to a written account (Kölbing 1876: 182). The relationships are visualized in Figure 4.

Andrews in his 1911 study took Kölbing's research as a point of departure and used Finnur Jónsson's edition to arrive at a contradicting conclusion, not only regarding the relationships between the rimur and the saga, but also regarding the relationships among manuscripts of Griplur. Andrews believed that C42 and A146 are descendants of a common exemplar $\left(\mathrm{R}^{2}\right)$, while $\mathrm{A} 610$ is independent from them and a descendant of $\mathrm{R}^{1}$ (Andrews 1911: 534-537). He also suggested that Acc 22 is a descendant from $\mathrm{R}^{4}$, which is again independent from the remaining manuscripts, so he classified the four manuscripts of Griplur known to him into three independent branches of oral tradition. Andrews' analysis of Acc22 was not as thorough as his analysis of the remaining manuscripts, as Acc22 is not included in his overview of the collation and the only comment regarding Acc22 appears in a footnote (Andrews 1911: 535, 540). Finally, Andrews considered the seventeenth-century saga to be secondary to the rimur and based on the separate branch of Griplur tradition $\left(\mathrm{R}^{3}\right)$, as visualized in Figure 5 .

A few decades later, Björn K. Pórólfsson (1934: 353) summarized the relationships between the manuscripts of Griplur as follows:

Besti texti rímnanna er í AM 610, 4to. Mikið af peim er í Kollsbók, en par er röð erinda mjög brjáluð. Í AM 146, 8vo er byrjun og endir rímnanna, brot úr texta náskyldum Kollsbók en pó ekki frá henni komnum. Enn fremur eru Griplur í 


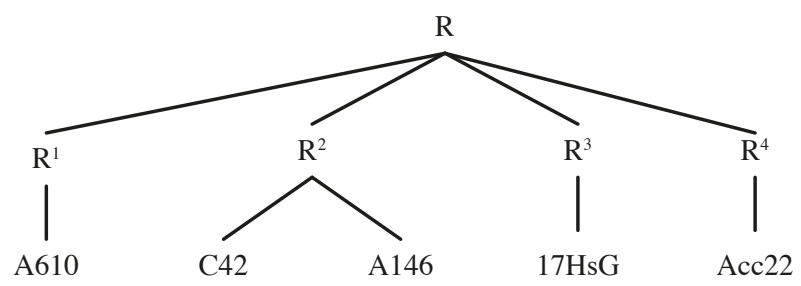

Fig. 5. Visualization of Andrews' interpretation of the relationships among four witnesses of Griplur (C42, A610, A146, Acc22), and the saga (17HsG), which is irrelevant for the current discussion.

Kálfavíkurbók, og eru par ýmsir leshættir betri en í hinum handritunum. Texti Kálfavíkurbókar er skyldari Kollsbók og 146 en 610.

Even though Björn did not present any stemma of this tradition we can conclude that in his interpretation Acc22 should be considered a manifestation of the same oral tradition as A146 and C42. This would essentially correspond to Andrews' $\mathrm{R}^{2}$ and eliminate the existence of $\mathrm{R}^{4}$. It has to be noted, however, that Björn - when describing each of these manuscripts separately - listed Griplur in A146, A610 and Acc22 among the rimur which are preserved in texts unknown from older manuscripts. This might suggest that each manuscript can be seen as an independent manifestation of the oral tradition, which would correspond to Andrews' interpretation with $\mathrm{R}^{1-4}$.

As previously discussed, only four manuscripts of Griplur have been the subject of scholarly investigations: C42, A146, A610, and Acc22. It must be emphasized, however, that the readings of C42 in the scholarly editions rely on A387, which has exclusively been used as a transcript of C42. Another two manuscripts, J55 and L1370, remained outside the scope of the previous scholarship, and their relationships to the remaining manuscripts have never been revealed.

The portion of text which can be compared among all the known manuscripts of Griplur amounts to approx. 23 stanzas, mainly due to a large lacuna in A146, from I:37 to VI:36, but also due to the lacunas in other manuscripts in the areas where A146, in turn, does not have a lacuna, i.e. in C42, from I: 1 to I:53, and in L1370, from I:1 to I:57. The following sections focus mainly on establishing the relationship between L1370, a hitherto ignored manuscript in the tradition of Griplur, and the remaining texts, but the relationships between other manuscripts are also revised. 


\subsection{Relationship between A387 and C42}

As can be concluded from the manuscript descriptions presented above, the relationship between A387 and C42 is fairly straightforward: A387 is the scholarly transcription of $\mathrm{C} 42$. The value of $\mathrm{A} 387$ from the perspective of textual criticism lies mainly in the fact that the readings of A387 can help us to decipher partially illegible readings of C42. Over a hundred years had passed between the copying of A387 and the publication of the facsimile edition of C42 by Ólafur Halldórsson (1968), therefore it is easy to imagine that the parchment is more worn out now than it was in 1849 .

A387 is, however, not a perfect scholarly copy of C42. Not only does the orthography of the manuscript not follow the orthography of the exemplar, but there are also examples where the text is inaccurate. For example, in C42 we can read "Par mun / uindur skyni / leysa sull ur sjó" (f. 65v:11) where "uindur skyni" is deleted, while A387 does not record the deletion and gives the reading "Par mun leysa sull úr sjó" (f. 225r:19). This example is perhaps not crucial for establishing the relationships among the manuscripts, but other examples are. For example, in A387 there is a reading "pá tók af hondum enda saums" (f. 227r:17) but the corresponding reading in C42 reads "pa tok af honum enda saums" (f. 66r:15). This erroneous example was used as a variant in Finnur Jónsson's edition: "honum: họndum" (Finnur Jónsson 1905-1922: 406). Consequently, it also appeared in Andrews' analysis of the relationship between the rimur manuscripts (Andrews 1911: 536).

\subsection{Relationship between J55 \\ and its exemplars A610 and A146}

Based on the manuscript descriptions above, we can also reveal a fairly straightforward relationship between J55 and its exemplars, A610 and A146: J55 is a scholarly transcription which utilizes both A146 and A610. References to both manuscripts are given explicitly in the marginal notes. For example, on f. 66v the marginal note reads: "[bls. 84 efst] Hér hefir 610 upp aptur 22-26 erindi og fram í priðju línu af 27. erindi (...sæk..) og er petta óvart ordið og strikað fyrir." J55 follows A146 as the base text for stanzas I:1-I:36, and later, where A146 has a lacuna, it follows A610. For stanzas I:1-I:36 variants from A610 are given as supralinear additions. Stanzas from I:37 onward follow A610 exclusively, and even in the part of the text where A146 again picks up the text of Griplur, stanzas VI:37VI:58, no variants from A146 are given. The text of J55 is a reliable copy 
of both A146 and A610 in the respective parts of the rimur, where it to some extent - preserves the orthography of the exemplars, but silently expands the abbreviations.

\subsection{Relationship between L1370 and A146}

Unlike in the two previous examples, there is no direct evidence that L1370 is based on A146, but the textual similarities between these two manuscripts are so striking that it is difficult to argue in favor of any other interpretation. Even though due to the lacunas in L1370 and A146 the amount of text which can be compared in these two manuscripts is rather sparse and consists only of stanzas VI:37-VI:58, the comparison shows clearly enough that L1370 preserves a text which is almost identical to the one preserved in A146. First of all, the order of stanzas in both manuscripts is the same and both manuscripts contain the additional stanza, which does not appear in A610: stanza VI:44bis, appearing between stanzas VI:44 and VI:45 of Rímnasafn (see Table 2 in the appendix). Moreover, L1370 and A146 always agree with each other in respect to variant readings, and no single variant can be found where they disagree. The only differences are in the orthography and in the abbreviations, for example: ${ }^{16}$

“hrömund gripßon” L1370] "hromund gripfon” A146.

“wilia paug effter” L1370] “vilia pau eptir” A146.

Despite the small sample size, there are some readings which separate A146 and L1370 from the texts preserved in the remaining manuscripts, for example:

brotið hús en höggnar dyr A146, L1370] hús er brotið en höggnar dyr A610, C42, Acc22.

meðann lífið vinst A146, L1370] meðan æfin vinst A610, C42, Acc22.

er firri kóngum stæði A146, L1370] sem fornum (fyrrum C42) kongum (kongi A610) stæði A610, C42, Acc22.

Taking into consideration the chronology of these two manuscripts, A146 being written between 1633-1700 and L1370 being broadly dated to

${ }^{16}$ Lists of textual variants present readings in semi-normalized orthography without quotation marks, but when the orthography is important for argumentation, I present diplomatic transcriptions of texts and place them in quotation marks. 
$1700-1800$, we can conclude that the text of Griplur in L1370 is a descendant of A146. Therefore, the readings of L1370 can be used to determine the relationship between A146 and the remaining manuscripts in the part of the text where A146 has a lacuna.

\subsection{Relationships based on the order of stanzas}

There are multiple differences in the order of stanzas between known manuscripts of Griplur. They are illustrated in Table 2 in the appendix. It includes only the five primary manuscripts of Griplur, as there are no repositioned stanzas in the scholarly transcripts. Table 2 illustrates all the instances of repositioned stanzas (highlighted in light grey), additional stanzas (highlighted in dark grey), and omitted stanzas (highlighted in black). For the reader's convenience the comparison takes its point of departure in the stanza numbers from Rímnasafn.

\section{Relationship between L1370 and C42}

Due to large lacunas in both L1370 and C42, a comparison of their texts is possible only for stanzas III:4-III:28 and IV:16-VI:58 (see Table 2). The results of this comparison suggest that C42 and L1370 belong to the same branch of Griplur tradition. The similarities are especially clear in rima III and IV, while in ríma $\mathrm{V}$ and VI there are still some common points, but L1370 diverges frequently from $\mathrm{C} 42$.

In the third rima both C42 and L1370 omit stanza III:12, which is present in both Acc22 and A610. Moreover, stanza III:13 appears immediately after III:8, so either III:9-III:12 are omitted, or L1370, which now has a lacuna up to III:4, used to agree with C42, in which III:9-III:11 appear between stanzas III:3 and III:4. A number of other stanzas is transposed in C42 and L1370 in contrast to the remaining manuscripts, for instance, III:22 follows III:53, III:25 follows III:29, III:27 follows III:25, III:28 follows III:30, and III:29 follows III:22.

In the fourth rima in L1370 stanza IV:22 is either omitted, or L1370 used to agree with C42 where IV:22 appears after IV:15, but L1370 now has a lacuna there. In both manuscripts stanza IV:31 is omitted, while both Acc22 and A610 preserve this stanza.

In the fifth rima, in both manuscripts, V:36 appears after V:31 and V:47 after V:49. Both manuscripts also contain stanza V:35bis in the same position and stanza V:27bis, which in addition to L1370 and C42 also appears in Acc22. There are, however, some discrepancies. L1370 con- 
tains an additional stanza which is attested only in this manuscript and appears between $\mathrm{V}: 35$ and $\mathrm{V}: 35$ bis (I refer to it as V:35x). Stanza V:50 in L1370 appears after V:45, but in C42 after V:47. Finally, V:46 is omitted in L1370, while $\mathrm{V}: 48$ bis is omitted in $\mathrm{C} 42$, and $\mathrm{V}: 48$ appears after $\mathrm{V}: 47$ in L1370, but after V:46 in C42.

In the sixth rima L1370 mostly disagrees with C42. For example, stanzas VI:19-VI:20 appear immediately after VI:8, followed by VI:17VI:18 and VI:15 (following the stanza order of Acc22), while in C42 these stanzas follow the same order as A610. Likewise, in L1370 VI:23-VI:24 follow VI:14, and VI:25-VI:26 follow VI:29, while in C42 these stanzas follow again the order of A610. L1370 and C42 do, however, share the presence of VI:44bis, which also appears in A146 and Acc22.

Based on the order of stanzas, it seems most likely that L1370 and C42 are derived from a common ancestor, but L1370 cannot be a descendant of C42. This is clear in rímur V and VI where L1370 frequently aligns with Acc22 against C42.

\section{Relationship between L1370 and A610}

Since A610 contains a complete text of Griplur, a comparison of L1370 and A610 is possible everywhere where L1370 does not have a lacuna. The comparison shows that these two manuscripts must belong to two different branches of the tradition of Griplur. Each of them contains some stanzas which the other one does not contain. On the one hand, L1370 contains stanzas I:60bis, V:5, V:27bis, V:35bis, V:48bis, VI:44bis, none of which appears in A610. On the other hand, stanzas I:63 and II:4-II:5 are present in A610, but not in L1370.

The order of some of the stanzas is also different. For example, the order of stanzas VI:55-VI:56 is reversed in A610, while stanzas III:24III:30 follow a completely different order in L1370 (see the overview in Table 2).

\section{Relationship between 1370 and Acc22}

Since Acc22 also contains a complete text of Griplur, a comparison of L1370 and Acc22 is possible everywhere where L1370 does not have a lacuna. The comparison shows that these two manuscripts agree frequently with each other against A610, but each of the two has its own individual features which are not present in the other. They tend to agree with each other in rimur I and II, and at the beginning of rima III, but from stanza III:23 they start to disagree. An exception is the order of stanzas VI:19- 
VI:20, which appear after VI:8 and are followed by VI:17, VI:18, VI:15, VI:10, and VI:9, where Acc22 and L1370 agree against A610 and C42. Moreover, they both contain stanzas I:60bis, V:27bis, V:48bis, VI:44bis, and in both the order of stanzas II:2-II:3 is reversed and stanzas II:4II:5 are omitted. But I:63, II:15, III:12 VI:16, and VI:21-VI:22 appear in Acc22 while they are omitted in L1370, and III:17 appears after III:19 in Acc22, while in L1370 it appears after III:15.

\section{Relationship between $\mathrm{C} 42$ and Acc22}

Similar to the previous case, since Acc22 contains a complete text of Griplur, a comparison of C42 and Acc22 is possible everywhere where C42 does not have a lacuna: from stanza II:54 to the end of the poem.

At the beginning of the third rima $\mathrm{C} 42$ agrees with Acc22 fairly frequently. For example, both contain III:9-III:11 after III:3, III:18 after III:20 and III:20 after III:23. However, there are already some differences at the beginning of the rima: III: 12 is omitted in C42, while it is present in Acc22 and III:17 appears after III:19 in Acc22. The stanza order in C42 in the later part of the third rima is much different from Acc22. For example, in C42 stanza III:38 appears after III:35, III:44 appears after III:40, and III:46 is omitted, while in Acc22 these stanzas follow the order of A610.

In the fourth rima Acc22 frequently disagrees with C42. For example, in C42 stanza IV:22 appears after IV:15 followed by IV:9, while stanza IV:31 is omitted. The same tendency can be found in the fifth and the sixth rima, where the only common points for Acc22 and C42 against A610 are the presence of V:27bis and VI:44bis and the order of stanzas VI:17-VI:18, which appear after VI:20. In C42, however VI:19-VI:20 appear after VI:16, while in Acc22 they appear after VI:8.

\section{Relationship between $\mathrm{C} 42$ and $\mathrm{A610}$}

Here again A610 contains a complete text of Griplur, therefore a comparison of C42 and A610 is possible everywhere where C42 does not have a lacuna: from stanza II:54 to the end of the poem. It is clear from a comparison of the stanza order of A610 and C42 that these two manuscripts preserve texts of Griplur which belong to different branches of the tradition. C42 contains additional stanzas which are not present in A610, for example V:27bis, V:35bis, and VI:44bis. Conversely, C42 omits some of the stanzas A610 contains, for example III:12, III:46, and IV:31. 
Relationship between Acc22 and A610

Acc22 and A610 are the only two manuscripts which preserve complete texts of Griplur, allowing detailed comparison. Based on the order of stanzas these two manuscripts must belong to two separate branches of the Griplur tradition. Stanza III:32 appears after III:34 in A610 while it is in its regular position in Acc22. III:22 appears after III:18 following III:20 in Acc22. Acc22 contains additional stanzas which are not present in A610, for example, I:60bis, II:17bis, V:27bis, and VI:44bis.

Relationship between Acc22, A146, A610, and C42

The amount of text which can be compared in Acc22, A146, and A610 is very sparse, consisting of stanzas I:1-I:34 and VI:37-VI:58. In the first part only these three manuscripts can be compared, but in the second part they can also be compared with $\mathrm{C} 42$.

In the first part, A146 stands alone against A610 and Acc22, which both have stanza I:34 after I:36. Additionally, A146 has stanza I:12 after I:24, while both A610 and Acc 22 have it in its regular position. This suggests that A146 belongs to a different branch then A610 and Acc22.

In the second part, A146 parallels C42 against A610 and Acc22, which both preserve stanzas VI:55-VI:56 in a reversed order. A146, C42, and Acc22 agree, however, with each other against A610 in that they all contain stanza VI:44bis, which is absent from A610.

Relationship between Acc22, A610, C42, and L1370

Acc22, A610, C42, and L1370 can be compared in stanzas III:4-III:28 and IV:16-VI:58. Stanzas III:12 and IV:31 are omitted in L1370 and C42, but Acc22 and A610 both contain these stanzas. C42, Acc22, and L1370 agree with each other against A610, as in all three of these manuscripts the order of stanzas III:15-III:16 is reversed. The same three manuscripts also contain stanza V:27bis, which is omitted in A610. V:48bis appears only in Acc22 and L1370.

The order of stanzas demonstrates that each manuscript has its unique features: Acc22 stands alone against the other three, for example when III: 17 appears after III:19, while in A610, C42, and L1370 it appears after III:15. A610 stands alone against the other three as it omits V:5, V:27bis, and VI:44bis. C42 stands alone regarding the order of the stanzas VI:17VI:20, as well as the position of V:50. L1370 stands alone regarding the order of the stanzas $\mathrm{V}: 47-\mathrm{V}: 48$ and in including stanza $\mathrm{V}: 35 \mathrm{x}$, which all 
the other manuscripts omit. Moreover, L1370 is also the only manuscript that omits VI:16 and VI:21-VI:22.

\subsection{Textual variants}

If we exclude chronological criteria and focus only on the relationships between the texts, ${ }^{17}$ we can clearly see that text of none of the known manuscripts could have been an exemplar of the remaining ones. For the reader's convenience the lists of variants presented below are collated against Rimnasafn and the stanza numbers follow the edition; when no siglum is given it means that the manuscript's reading agrees with that of the edition.

The manuscript which provided the base text of Finnur Jónsson's edition of Griplur, A610, cannot be the exemplar because it has many individual readings, such as:

III:18:1 sigri veldr] sigr er skaptr A610.

III: 14:1 Oss er mál] Ant er mér A610.

V:15:2 veitti] hrepti A610.

C42 cannot be the exemplar because of its individual readings, such as:

IV:60:1 kláz] fázt C42.

IV:62:3 lét ekki] réð ei C42.

$\mathrm{V}: 44: 2$ verða] purfa $\mathrm{C} 42$.

Acc22 cannot be the exemplar because of its individual readings, such as:

III:22:1 stelumz] stelst Acc22.

IV:51:2 drepr] lemr Acc22.

V:51:3 Hverfi] Hárs skal Acc22.

L1370 (and A146) cannot be the exemplar because of its individual readings, such as:

III:13:4 petta starfad] mikit starfad L1370.

IV:45:2 Hrólfr] Hrafn L1370.

V:4:1 garð] skarð L1370.

${ }^{17}$ This approach is inspired by the work of, among others, Barbara Bordalejo (2015). 
Based on textual criteria, it is also clear that L1370 belongs to the same tradition as $\mathrm{C} 42$, as there are many examples where these two agree with each other in places where A610 and Acc22 share a different reading, for example:

III: 15:2 rekkar] rekkrinn C42, L1370.

IV:46:2 Gripsson út af tjaldi gengr] Gripsson upp úr tiallde sprettur C42, L1370.

V:16 seima rjóðr] seggrinn fróðr C42, L1370.

L1370 also agrees with C42 where A610 and Acc22 offer different readings:

III:22:3 karpar pú] krappar pú A610; pú kjaftar hér Acc22.

IV:59:1 reiðir] mælti i A610; talar við Acc22.

V:8:1 stóran] sterkan leit A610; sterkur Acc22. ${ }^{18}$

V:17:14 fjórtán] fimtán A610; seytján Acc22.

Where L1370 disagrees with C42, it frequently parallels Acc22, but some of the readings are so minor that they cannot be treated as relationshiprevealing readings:

III:15:1 Nú er í reiðing] nú er í reiki A610; Nú er á reiki Acc22, L1370.

III:15:4 að hófi] á hófi Acc22, L1370.

V:51:2 litit vinni] ekki finni A610; leitum linni Acc22, L1370.

L1370 agrees with A610 against the remaining manuscripts only in cases which, according to Finnur Jónsson's (1905-1922) editorial choices, were original readings:

IV:58:4 að velli] á voll C42; á ís Acc22.

VI:29:2 slíkt] pað C42, Acc22.

Based on these textual variants it has to be assumed that either we are dealing with four separate branches of the textual stemma, or even four separate oral traditions, or that L1370 changed its exemplar halfway through ríma $\mathrm{V}$,

\footnotetext{
${ }^{18}$ In Rímnasafn the variant from Acc22 is presented as "sterkr".
} 
and this exemplar belonged to a different branch of the stemma, as showed by the presence of $\mathrm{V}: 35 \mathrm{x}$, position of $\mathrm{V}: 50$, omission of $\mathrm{V}: 46$, etc.

Another possibility is that stanzas ca. V:35-VI:27 in L1370 were supplied from memory, as their order does not correspond to any other manuscript. Yet another possibility, which seems very attractive but is equally difficult to prove, is that $\mathrm{C} 42$ changed its exemplar, rather than L1370. In C42 there is a hand shift on $\mathrm{f} .64 \mathrm{v}: 18$, at the beginning of stanza $\mathrm{V}: 19$, and two hands are responsible for stanzas V:19-VI:32:

From f. 64v:18 to f. 65v:8 Hand 3 (to stanza VI:14).

From f. 65v:8 to f. 65v:20 Hand 11 (to stanza VI:22).

From f. 65v:20 to f. 65v:26 Hand 3 (to stanza VI:25).

From f. 65v:26 to f. 65v:36 Hand 11 (to stanza VI:32).

It is easy to imagine that in the medieval scriptorium in which $\mathrm{C} 42$ was most likely copied, as it is written in twelve different hands, more than one text of Griplur would have been available and multiple texts could have been used interchangeably to produce $\mathrm{C} 42$. Another text must have been used from stanza V:19 onwards in C42, while L1370 preserves the stanzas in the order more closely related to the common ancestor of C42 and L1370, which is in turn closer to Acc22 than to A610.

The textual variation in this part of the rimur seems to confirm this hypothesis. If we look at stanzas VI:19-VI:20, which are repositioned in Acc22 and L1370, L1370 seem to preserve better readings than C42:

VI:19:1 einum] vorum A610, Acc22, L1370.

VI:19:2 eg vil] vil eg A610, Acc22, L1370; eg mä C42.

VI:20:1 koma mun vindr úr skýjum skæðr] Par mun vindr af skogi skæðr C42. ${ }^{19}$

\footnotetext{
${ }^{19}$ In this context it is important to mention that the editorial principles of Rímnasafn are rather unclear. For example, if we focus on stanza 19, we can clearly see that Finnur Jónsson not only chooses the "incorrect" reading in the first line but also emends the text of the second line without any clear reason. The beginning of stanza 19 in Rimnasafn reads: "Var pað enn í einum draum I eg vil greina tiggja," where A610, Acc22 and L1370 agree against C42 in reading "vorum" for "einum". "Vorum" can be considered more correct, as it fits the alliteration of the letter v (var, vorum, vil). It also seems that the poet tried to have the alliteration in the first word of the second line, for example in stanza 18: "Húsin vór munu hefjaz öll, I hygg eg pað fyr góður." Here, the alliterating h appears in the first word of the second line, and so the reading "vil eg", as offered in stanza 19 in A610 and Acc22 and L1370, should be preferred over the emendation "eg vil" in the second line.
} 
Similarly, in the penultimate stanza of the sixth rima $\mathrm{C} 42$ has a reading that does not fit the rhyming scheme of the stanza, as "synja" does not rhyme with "heita". This stanza reads as follows in C42:

Vísna biðja voldug sprund

Valla ma peim synja

Glósað hef eg gaman um stund

Griplur skulu pær heita (C42)

In Rimnasafn, which follows A610, the stanza reads as follows:

Kvæða biðja kurteis sprund

eg kan peim ekki neita

glósað hef eg gaman um stund;

Griplur skulu pað heita. (VI:57)

The important variants are:

VI:57:2 Kvæða ${ }^{20}$ biðja kurteis] vísna biðja voldug C42, A146, L1370.

VI:57:2 eg kann peim ekki neita] valla ma peim synja C42; vilja pau eptir leita A146, L1370.

Based on the alliterations present in this stanza we can distinguish two groupings of Griplur texts. The first group includes A610 and Acc22 and the stanza alliterates on k: kvæða, kurteis, kann. The second group includes C42, A146, and L1370 and the stanza alliterates on v: vísna, volldug, vilja (A146, L1370) / valla (C42). ${ }^{21}$

In the part of the rimur where we can compare all known texts of Griplur, A146 does not agree with C42 eight times out of thirty-two, but the majority of these variants are fairly minor, and the only readings which could be considered major are the following:

VI:37:3 hus er brotid C42] brotid hus A146.

VI:42:3 æfin vinzt C42] lijfit vinst A146.

VI:57:2 valla ma peim synja C42] vilja pau eptir leita A146.

The two first readings are independent innovations of A146, while the

\footnotetext{
${ }^{20}$ In Acc22 the reading is "Ef kvæða..." but this is not significant from perspective of the current analysis.

${ }^{21}$ This can be compared with the variation of Skikkju rimur, where even when there is variation in the alliterative words the alliteration is always preserved (see Driscoll 1997: 233).
} 


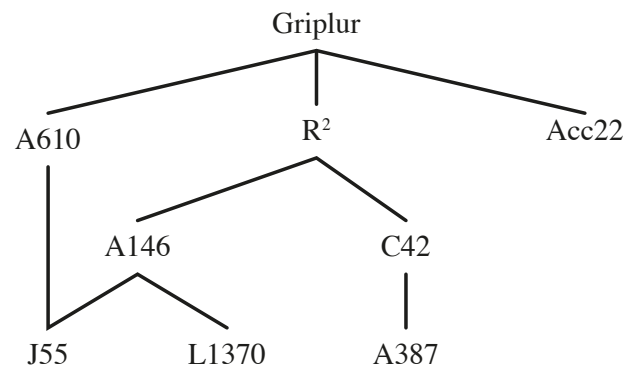

Fig. 6. Relationships between the extant texts of Griplur

third one is an independent innovation of $\mathrm{C} 42$, so they do not exclude a common ancestor for both.

\subsection{Summary of the relationships}

Based on the preceeding analysis some of the relationships among the extant texts of Griplur can be revealed with a high degree of certainty. First of all, the textual analysis confirmed the dependency of the two scholarly manuscripts (J55 and A387) on their exemplars. As suggested by the internal evidence, the text of Griplur in A387 is a more or less reliable transcript of $\mathrm{C} 42$, while the text in $\mathrm{J} 55$ is a compilation of the texts preserved in A146 and A610. Secondly, through observations of the stanza order and textual variation, the relationships between L1370 and the remaining manuscripts were revealed. L1370 appears to be a descendant of A146, as the only differences between these two texts are on the level of orthography. Moreover, L1370 frequently agrees with C42, which appears to be closely related to A146. Thus, three branches of the Griplur tradition can be distinguished. One branch includes A610 and its descendant J55. The second branch is represented by A146, L1370, C42,A387 and partially J55. The third branch is represented by Acc22. (Figure 6).

\section{Conclusion}

This article presented the first ever analysis of all known manuscripts preserving the texts of Griplur, the medieval set of rimur of Hrómundur, son 
of Gripur. Griplur are preserved in seven known manuscripts, of which only one, $\mathrm{C} 42$, can be dated to the medieval period. The remaining manuscripts can be dated to the seventeenth, eighteenth, and nineteenth century.

Through the analysis of the manuscript contexts in which Griplur appear, the present study revealed that Griplur appear most frequently with other rimur related to chivalric and legendary sagas. This casts some light on the transmission and reception of these texts, as we can assume that the texts which travelled together in manuscripts were also produced and consumed together. The present study demonstrated that Andra rimur, are the most frequently occurring alongside Griplur, and both are based on lost medieval legendary sagas which appear to be also closely related. Even though we cannot make general conclusions based on one case study, this may suggest that rímur which share literary motifs also tend to share transmission history. At the same time, it is more difficult to explain why Ólafs rímur Tryggvasonar frequently co-occur with Griplur. It is possible that the events described in both sets of rimur were equally distant for the late-medieval and post-medieval audiences so that their contents were considered equally legendary, making our modern distinction between material related to kings' sagas and legendary sagas irrelevant.

The textual analysis of the texts preserved in all known manuscripts allowed us to expand the existing stemmas of Griplur. While the previous scholarship focused mainly on the three or four oldest manuscripts of Griplur, the present study included three additional manuscripts which were ignored in the previous scholarship: L1370 from 1700-1800, A387 from 1849-50, and J55 from ca. 1870. The relationships between these manuscripts were incorporated into a stemma of the tradition, as presented in Figure 6. This examination of the relationships among the texts of Griplur establishes a good basis for a further work on the new edition of the rimur. Even though the present study did not result in a revision of the relationships among C42, A610, and A146 established by Andrews, it confirmed his research results and expanded them by identification of the descendants of A610 and A146. In this context it is especially significant that L1370 has been identified as a descendant of A146, because the readings of L1370 can be used to fill in the lacuna of A146.

A new edition of Griplur based on the results of the present study would certainly present a different text than the one proposed in Rimnasafn. On one hand, the eclectic text based on strict stemmatic calculation would not follow A610, which served as a base text of Finnur's edition. On 
the other hand, due to the high amount of variation in this tradition, a better approach would be to edit each branch of the stemma or each text separately. In doing so, we would give the reader an opportunity to read the rimur in their actual historical manifestations. As Matthew Driscoll (1999: 271) observed while editing Skikkju rímur:

It must be remembered that, although composed in writing, rimur were intended for oral delivery and therefore retain some of the characteristics of oral literature. It must also be borne in mind that the rimur manuscripts were not produced in scriptoria by professional scribes, but rather by ordinary people, many of them poets themselves, and it is therefore likely that in the course of a poem's transmission various improvements will have been made. The text of Skikkjurimur preserved in AM Acc22 [...] should be viewed not as the text of Skikkjurimur, but rather as a text-or, better still, a performance-of Skikkjurímur.

Even though the assumption that rímur manuscripts were not copied in scriptoria seems unconvincing, as at least one manuscript of Griplur, C42, was most likely copied in a medieval scriptorium, the postulate that each text should be viewed as a "performance" is an important one when we take into consideration the post-medieval transmission and dissemination of the rímur. While historical oral performances of the rimur are beyond our reach, each of the extent manuscripts presents in a certain sense one "performance" of rímur, a performance which may be particular to the time and space of the manuscript's writing. By presenting multiple texts of the same work in a rimur edition, as it is done in many modern saga editions, we would significantly expand our understanding of the production, circulation, and perhaps even reception of these works in medieval and post-medieval Iceland.

The detailed study of Griplur has also further implications for the study of the transmission history of Hrómundar saga Greipssonar and related materials, as the story of Hrómundur exists in multiple post-medieval adaptations in prose and verse, including at least two sets of rimur and two sagas. Thanks to the present analysis we can ask further questions concerning the practice of turning prose into rimur and "back" into prose in Iceland. Further studies of this phenomenon will play an important role in expanding our knowledge about and understanding of not only literary development, but also the society of post-medieval Iceland. Cases such as Hrómundar sögur and rímur call into question the motivations behind the entire process of converting stories from one media to another. Why did someone convert rimur into prose in the first place? Moreover, why 
were some of the rimur, Griplur included, converted into prose more than once? Was it because of a lack of access to the prose version in a particular area, because of a dislike of their poetic form, or because of the need to simplify the poetic language and deliver an easily accessible story to the less sophisticated audience? None of these questions can be satisfactory answered without an in-depth textual analysis of the transmission history of various sets of rimur and related sagas.

\section{Acknowledgments}

This article draws on the research conducted during my doctoral fellowship at the Department of Nordic Studies and Linguistics, University of Copenhagen (2015-2018), but the writing of this article was possible thanks to the postdoctoral fellowship from Carlsberg Foundation, Dronning Margrethe den II's "Distinguished" forskningsprojekt om den danskislandske reception af den nordiske oldtid (2019-2021). I am grateful to many colleagues for inspiration, feedback, and support, especially Matthew James Driscoll and Annette Lassen, but also Tarrin Wills and Philip Lavender. Also, I owe thanks to Ryder Patzuk-Russell for feedback on language and style of the present article.

\section{Bibliography}

Aðalheiður Guðmundsdóttir, 2001: Úlfhams saga. Reykjavík.

Andrews, Albert LeRoy, 1911: "Studies in the fornaldarsogur Norðrlanda". Modern Philology 8. Pp. 527-544.

Björn K. Pórólfsson, 1934: Rímur fyrir 1600. Copenhagen.

Björner, Erik Julius (ed. and trans.), 1737: Nordiska kämpa dater i en sagoflock samlade om forna kongar och hjältar. Volumen historicum, continens variorum in orbe hyperboreo antiquo regum, heroum et pugilum res praeclare et mirabiliter gestas. Accessit, praeter conspectum genealogicum Svethicorum regum et reginarum accuratissimum etiam praefatio. Stockholm.

Bordalejo, Barbara, 2015: "The Genealogy of Texts: Manuscript Traditions and Textual Traditions". Digital Scholarship in the Humanities. 31 (3). Pp. 563-577.

Brown, Ursula, 1946: "The saga of Hrómund Gripsson and Porgilssaga". SagaBook 13. Pp. 51-77.

Brown, Ursula (ed.), 1952: Porgils saga ok Hafliða. London. 
Craigie, William A., 1949: "Nokkrar athuganir um rímur". Aukarit rímnafjelagsins. Reykjavík. Pp. 3-20.

Davíð Erlingsson, 1989: "Rímur”. In: Frosti F. Jóhannsson (ed.), Íslensk pjóðmenning. Reykjavík. Pp. 330-355.

Det Kongelige Nordiske Oldskriftselskab (ed.), 1852: Antiquarisk tidsskrift 1849-1851. Copenhagen.

Driscoll, Matthew James, 1997: "Words, words, words: Textual variation in Skikkjurímur”. Skáldskaparmál 4. Pp. 227-237.

Driscoll, Matthew James, 2011: "Arthurian Ballads, rímur, Chapbooks and Folktales". In: Marianne E. Kalinke (ed.), The Arthur of the North: The Arthurian Legend in the Norse and Rus' Realms. Cardiff. Pp. 168-196.

Driscoll, Matthew James, Hufnagel, Silvia Veronica, Lavender, Philip and Stegmann, Beeke (ed.), 2018: The Legendary Legacy: Transmission and reception of the Fornaldarsögur Norðurlanda. Odense.

Finnur Jónsson (ed.), 1896: Fernir forníslenskir rímnaflokkar. Copenhagen.

Finnur Jónsson (ed.), 1900: Landnámabók, Hauksbók, Sturlubók, Melabók m.m. Copenhagen.

Finnur Jónsson (ed.), 1905-1922: Rímnasafn: Samling af de ældste Islandske Rimer. Copenhagen.

Finnur Jónsson (ed.), 1930: Árni Magnússons levned og skrifter. Copenhagen.

Finnur Sigmundsson, 1966: Rímnatal. Reykjavík.

Foote, Peter, 1953-1957: “Sagnaskemtan: Reykhólar 1119”. Saga-Book 14. Pp. 226-239.

Glauser, Jürg and Tranter, Stephen N., 1990: "Romances, rímur, chapbooks. Problems of popular literature in late medieval and early modern Scandinavia". Parergon 8 (2). Pp. 37-52.

Guðni Jónsson (ed.), 1954: Fornaldarsögur Norðurlanda. Reykjavík.

Haukur Porgeirsson, 2013: “Hljóðkerfi og bragkerfi. Stoðhljóð, tónkvæði og önnur úrlausnarefni í íslenskri bragsögu ásamt útgáfu á Rímum af Ormari Fraðmarssyni”. (PhD thesis University of Iceland.) Reykjavík.

von Heinemann, Otto, 1966: Die Handschriften der Herzoglichen Bibliothek zu Wolfenbüttel. Nachdruck der Ausgabe 1884-1913. Frankfurt am Main.

Helgi Sigurðsson, 1891: Safn til bragfræði íslenzkra rímna að fornu og nýju. Reykjavík.

Hufnagel, Silvia Veronica, 2012: "Sörla saga sterka: Studies in the Transmission of a Fornaldarsaga". (PhD thesis University of Copenhagen.) Copenhagen.

Hughes, Shaun, 1980: "Report on Rímur 1980”. Journal of English and Germanic Philology 79 (4). Pp. 477-498.

Hughes, Shaun, 1982: "Rímur". In: Joseph Strayer (ed.), Dictionary of the Middle Ages. New York. Pp. 401-407.

Hughes, Shaun, 2005: “Late Secular Poetry”. In: Rory McTurk (ed.), A companion to Old Norse-Icelandic Literature and Culture. Oxford. Pp. 205-222.

Jesch, Judith, 1984: "Hrómundr Gripsson revisited". Skandinavistik 14 (2). Pp. 89-105. 
Jóhanna Katrín Friðriksdóttir and Haukur Porgeirsson, 2015: "Hrólfs rímur Gautrekssonar". Gripla 16. Pp. 81-137.

Jón Helgason, 1985: "Bækur og handrit á tveimur húnvetnskum höfuðbólum á 18du öld”. Landsbókasafn Íslandsk: Árbók 1983. Pp. 5-46.

Jón Porkelsson, 1888: Om digtningen på Island i det 15. og 16. århundrede. Copenhagen.

Jucknies, Regina, 2005: “Der Horizont eines Schreibers. Jón Eggertsson und seine Handschriften". (PhD thesis Rcheinischen Friedrich-Wilhelms-Universität.) Bonn.

Jucknies, Regina, 2009: Der Horizont eines Schreibers, Jón Eggertsson (164389) und seine Handschriften. Frankfurt am Main.

Kålund, Kristian, 1889-1894: Katalog over den Arnamagnæanske Håndskriftsamling. Copenhagen.

Kålund, Kristian, 1906-1911: Sturlunga Saga efter membranen Króksfjarðarbók udfyldt efter Reykjarfjarðarbók. Copenhagen.

Kapitan, Katarzyna Anna, 2018: "Studies in the Transmission History of Hrómundar saga Greipssonar". ( $\mathrm{PhD}$ thesis University of Copenhagen.) Copenhagen.

Kapitan, Katarzyna Anna, 2021: "When a King of Norway Became a King of Russia: Transmission and Reception of Hrómundar saga Greipssonar in Scholarly Networks of Early Modern Scandinavia". Scandinavian Studies 94.2.

Kapitan, Katarzyna Anna (forthcoming): "Flying Dragons, Magic Stones, and Prophetic Dreams: On the hitherto unknown adaptation of the lost legendary saga of Hrómundur Gripsson".

Katrín Jakobsdóttir, Sólveig Pétursdóttir and Ingibjörg Steinunn Sverrisdóttir, 2011: "Lífsverk Jón Sigurðsson 1811-2011”. In: Catalogue of the exhibition held at the National Library of Iceland from 20.04.2011. Reykjavík.

Klemming, Gustaf Edvard, 1880-1882: Ur en antecknares samlingar. Uppsala.

Kölbing,Eugen, 1876: Beiträge zur Vergleichenden Geschichte der Romantischen Poesie und Prosa des Mittelalters. Breslau.

Lansing, Tereza, 2011: "Post-medieval production, dissemination and reception of Hrólfs saga kraka". (PhD thesis University of Copenhagen.) Copenhagen.

Lavender, Philip, 2014: “Whatever Happened to Illuga saga Gríðarfóstra? Origin, Transmission and Reception of a Fornaldarsaga". (PhD thesis University of Copenhagen.) Copenhagen.

Lavender, Philip, 2019: "Bekraríma or 'The Rhyme of the Ram' by Eiríkur Hallsson”. In K.A. Kapitan, B. Stegmann, S.D. Vrieland (eds.), From Text to Artefact: Studies in Honour of Anne Mette Hansen. Leeds. Pp. 239-248.

Lavender, Philip, 2020: Long Lives of Short Sagas: The Irrepressibility of Narrative and the Case of Illuga saga Gríðarfóstra. Odense.

Ólafur Halldórsson, 1968: Kollsbók: Codex Guelferbytanus 42.7: Augusteus Quarto. Reykjavík.

Ólafur Halldórsson, 1973-1975: Íslenzkar miðaldarímur I-IV. Reykjavík. 
Páll Eggert Ólason, 1918-1937: Skrá um handritasöfn Landsbókasafnsins. Reykjavík.

Páll Eggert Ólason, 1948-1952: Íslenzkar æviskrár frá landnámstímum til ársloka 1940. Reykjavík.

Rafn, Carl Christian (ed.), 1829-1830: Fornaldar sögur Nordrlanda eptir gömlum handritum. Copenhagen.

Simek, Rudolf and Hermann Pálsson, 1987: Lexikon der altnordischen Literatur, die mittelalterliche Literatur Norwegens und Islands. Stuttgart.

Spehr, Ferdinand, 1875: "August der Jüngere, Herzog zu Braunschweig und Lüneburg". In: R. von Liliencron (ed.), Allgemeine Deutsche Biographie. Leipzig. Pp. 660-662.

Springborg, Peter, 1977: “Antiqvæ historiæ lepores - om renæssancen i den islandske håndskriftproduktion i 1600-tallet”. Gardar 8. Pp. 53-89.

Stefán Einarsson, 1955: "Report on Rímur". The Journal of English and Germanic Philology 54 (2). Pp. 255-261.

Stegmann, Beeke, 2016: “Árni Magnússon's rearangement of paper manuscripts”. (PhD thesis University of Copenhagen.) Copenhagen.

Svanhildur Óskarsdóttir and Lethbridge, Emily (eds.), 2018: New Studies in the Manuscript Tradition of Njáls saga: The historia mutila of Njála. Kalamazoo.

Sverrir Tómasson, 2012: "The function of Rímur in Iceland". In: BalladenStimmen, Vokalität als theoretisches und historisches Phänomen. Tübingen. Pp. 59-74.

Úlfar Bragason, 1994: “Ok pó kunna menn at telja ættir sínar til Hrómundar Gripssonar: Sagnaskemmtun á Reykhólum og Sturlunguhöfundur”. In: Samtíðarsögur: The 9th International Saga Conference Preprints. Akureyri. Pp. 784-98.

Valdimar Ásmundarson (ed.), 1886: Fornaldarsögur Norðrlanda. Reykjavík.

\section{Resumé på dansk}

Denne artikel undersøger transmissionshistorie af Griplur, et middelalderligt rimdigt af Hromund Gripsson (Greipsson), en legendarisk helt fra Norge der ifølge Landnamsbogen var en forfader til Islands første besættere Ingolf og Leif. Rimdigtet stammer fra senmiddelalder men det bevares hovedsagelig i eftermiddelalderlige håndskrifter og mange af dem har indtil nu været ignoreret $\mathrm{i}$ videnskabelige diskussioner. Artiklen præsenterer den første undersøgelse af alle håndskrifter af Griplur med hensyn til deres indhold og tekstuelle forbindelser og etablerer derved et grundlag til en ny kritisk udgave af dette værk. 


\section{Summary in English}

This article examines the transmission history of Griplur, a medieval set of rimur of Hrómundur Gripsson (Greipsson), a legendary hero from Norway and, according to Landnámabók, a forefather of the first settlers of Iceland, Ingólfur and Leifur. The rimur, which originate in the late Middle Ages, are preserved mainly in post-medieval manuscripts, and many of them have been ignored in the previous scholarship. The article presents the first study of all Griplur manuscripts with the focus on their contents and textual relationships, which lays the ground for a new critical edition of this work.

Keywords: Old Norse-Icelandic poetry, transmission history, manuscript studies, rímur, Hrómundar saga Gripssonar, Griplur

Katarzyna Anna Kapitan

University of Iceland

Vigdís Finnbogadóttir Institute of Foreign Languages

Brynjólfsgötu 1

107 Reykjavík

k.a.kapitan@gmail.com

www.kakapitan.com

ORCID ID 0000-0003-2763-0056 


\section{Appendix}

Tab. 2. Overview of the five main witnesses of Griplur. Highlighted in light grey: repositioned stanzas; highlighted in dark grey: additional stanzas; highlighted in black: omitted stanzas.

\begin{tabular}{|c|c|c|c|c|}
\hline A610 & $\mathrm{C} 42$ & A146 & Acc22 & L1370 \\
\hline I:1-I:11 & \multirow[t]{27}{*}{ lacuna to II:54 } & I: 1-I:11 & I:1-I:11 & \multirow[t]{9}{*}{ lacuna to I:56 } \\
\hline I:12 & & $\times(\mathrm{I}: 12$ after 24$)$ & $\mathrm{I}: 12$ & \\
\hline $\mathrm{I}: 13-\mathrm{I}: 24$ & & I: $13-I: 24$ & I:13-I:24 & \\
\hline$x$ & & I: 12 & $x$ & \\
\hline $\mathrm{I}: 25-\mathrm{I}: 33$ & & $\mathrm{I}: 25-\mathrm{I}: 33$ & $\mathrm{I}: 25-\mathrm{I}: 33$ & \\
\hline$\times(\mathrm{I}: 34$ after 36$)$ & & $\mathrm{I}: 34$ & $\times(\mathrm{I}: 34$ after 36$)$ & \\
\hline $\mathrm{I}: 35-\mathrm{I}: 36$ & & I:35-I:36 & I:35-I:36 & \\
\hline $\mathrm{I}: 34$ & & $x$ & $\mathrm{I}: 34$ & \\
\hline I:37-I:56 & & \multirow[t]{19}{*}{ lacuna to VI:37 } & I:37-I:56 & \\
\hline I:57-I:60 & & & I:57-I:60 & I:57-I:60 \\
\hline$x$ & & & I:60bis & I:60bis \\
\hline I:61-I:62 & & & I:61-I:62 & I:61-I:62 \\
\hline I:63 & & & I:63 & $\times(\mathrm{I}: 63$ omitted $)$ \\
\hline I:64-I:67 & & & I:64-I:67 & I:64-I:67 \\
\hline II:1 & & & II:1 & II: 1 \\
\hline II:2 & & & II:3 & II:3 \\
\hline II:3 & & & II:2 & II:2 \\
\hline II:4-II:5 & & & $\begin{array}{l}\times(\mathrm{II}: 4-\mathrm{II}: 5 \\
\text { omitted })\end{array}$ & $\begin{array}{l}\times(\text { II:4-II:5 } \\
\text { omitted })\end{array}$ \\
\hline II:6 & & & II:6 & II:6 \\
\hline II: 8 & & & II:7 & II: 7 \\
\hline II:7 & & & II:8 & II: 8 \\
\hline$x$ & & & II:12 & II: 12 \\
\hline II:9-II:10 & & & II:9-II:10 & II:9-II:10 \\
\hline II:11 & & & $\times(\mathrm{II}: 11$ omitted $)$ & $\begin{array}{l}\times(\mathrm{II}: 11 \\
\text { omitted })\end{array}$ \\
\hline II:12 & & & $\times(\mathrm{II}: 12$ after 8$)$ & × (II:12 after 8$)$ \\
\hline II:13 & & & $\times($ II:13 omitted $)$ & $\times($ II:13 omitted $)$ \\
\hline II:14 & & & II:14 & II: 14 \\
\hline
\end{tabular}




\begin{tabular}{|c|c|c|c|c|}
\hline A610 & $\mathrm{C} 42$ & A146 & Acc22 & L1370 \\
\hline II:15 & & & II:15 & $\times($ II:15 omitted $)$ \\
\hline II:16-II:17 & & & II:16-II:17 & II: 16-II:17 \\
\hline$x$ & & & II:17bis & $\begin{array}{l}\text { lacuna } \\
\text { II:18-III:3 }\end{array}$ \\
\hline II:18-II:23 & & & II:18-II:23 & \\
\hline II:24 & & & II:25 & \\
\hline II:25 & & & II:24 & \\
\hline II:26-II:33 & & & II:26-II:33 & \\
\hline II:34 & & & $\begin{array}{l}\times(\text { II:34 after } \\
\text { II:37) }\end{array}$ & \\
\hline II:35-37 & & & II:35-37 & \\
\hline$\times$ & & & II:34 & \\
\hline II:38-II:53 & & & II:38-II:53 & \\
\hline II:54-II:56 & II:54-II:56 & & II:54-II:56 & \\
\hline II:59 & $\times(\mathrm{II}: 59$ omitted $)$ & & $\times($ II:59 omitted $)$ & \\
\hline II:57-II:58 & II:57-II:58 & & II:57-II:58 & \\
\hline$\times($ II:59 after 56) & II:59 & & II:59 & \\
\hline II:60-II:62 & II:60-II:62 & & II:60-II:62 & \\
\hline III:1-III:3 & III:1-III:3 & \multirow[t]{12}{*}{ lacuna to VI:37 } & III:1-III:3 & \multirow[t]{2}{*}{ lacuna to III:3 } \\
\hline$x$ & III:9-III:11 & & III:9-III:11 & \\
\hline III:4-III:8 & III:4-III:8 & & III:4-III:8 & III:4-III:8 \\
\hline III:9-III:11 & $\begin{array}{l}\text { × (III:9-III:11 } \\
\text { after III:3) }\end{array}$ & & $\begin{array}{l}\text { × (III:9-III:11 } \\
\text { after III:3) }\end{array}$ & $\begin{array}{l}\times(\text { III:9-III: } 11 \\
\text { after III:3 or } \\
\text { omitted)? }\end{array}$ \\
\hline III:12 & $\begin{array}{l}\times(\mathrm{III}: 12 \\
\text { omitted })\end{array}$ & & III:12 & $\begin{array}{l}\times(\text { III: } 12 \\
\text { omitted })\end{array}$ \\
\hline III:13 & III: 13 & & III:13 & III:13 \\
\hline III:14 & III: 14 & & III: 14 & III: 14 \\
\hline III:15 & III: 16 & & III:16 & III:16 \\
\hline III:16 & III: 15 & & III:15 & III:15 \\
\hline III:17 & III: 17 & & $\begin{array}{l}\times \text { (III: } 17 \text { after } \\
\text { III:19) }\end{array}$ & III:17 \\
\hline III:18 & $\begin{array}{l}\times \text { (III: } 18 \text { after } \\
\text { III:20) }\end{array}$ & & $\begin{array}{l}\times(\mathrm{III}: 18 \text { after } \\
\mathrm{III}: 20)\end{array}$ & $\begin{array}{l}\times(\text { III: } 18 \text { after } \\
\text { III:20) }\end{array}$ \\
\hline III:19 & III: 19 & & III: 19 & III: 19 \\
\hline
\end{tabular}




\begin{tabular}{|c|c|c|c|c|}
\hline A610 & $\mathrm{C} 42$ & A146 & Acc22 & L1370 \\
\hline$x$ & $x$ & & III:17 & $x$ \\
\hline III:20 & $\begin{array}{l}\times(\text { III: } 20 \text { after } \\
\text { III:23) }\end{array}$ & & $\begin{array}{l}\times(\text { III: } 20 \text { after } \\
\text { III: } 23)\end{array}$ & $\begin{array}{l}\times(\text { III }: 20 \text { after } \\
\text { III: } 23)\end{array}$ \\
\hline III:21 & III: 21 & & III 21 & III:21 \\
\hline III:22 & $\begin{array}{l}\times \text { (III:22 after } \\
\text { III:53) }\end{array}$ & & $\begin{array}{l}\times \text { (III: } 22 \text { after } \\
\text { III:18) }\end{array}$ & $\begin{array}{l}\times(\text { III: } 22 \text { after } \\
\text { III:53) }\end{array}$ \\
\hline III:23 & III:23 & & III:23 & III:23 \\
\hline$\times$ & III:20 & & III:20 & III:20 \\
\hline$\times$ & III: 18 & & III: 18 & III: 18 \\
\hline$\times$ & $x$ & & III:22 & $x$ \\
\hline III:24 & III:24 & & III:24 & III:24 \\
\hline III:25 & $\begin{array}{l}\times(\text { III: } 25 \text { after } \\
\text { III:29) }\end{array}$ & & III:25 & $\begin{array}{l}\times(\text { III: } 25 \text { after } \\
\text { III:29) }\end{array}$ \\
\hline III:26 & III:26 & & III:26 & III:26 \\
\hline III:27 & $\begin{array}{l}\times(\text { III: } 27 \text { after } \\
\text { III:25) }\end{array}$ & & III:27 & $\begin{array}{l}\times(\text { III }: 27 \text { after } \\
\text { III:25) }\end{array}$ \\
\hline III:28 & $\begin{array}{l}\times(\text { III: } 28 \text { after } \\
\text { III: } 30)\end{array}$ & & III:28 & $\begin{array}{l}\times(\mathrm{III}: 28 \text { after } \\
\text { IIII:30) }\end{array}$ \\
\hline III:29 & $\begin{array}{l}\times(\text { III: } 29 \text { after } \\
\text { III:22) }\end{array}$ & & III:29 & $\begin{array}{l}\times(\text { III }: 29 \text { after } \\
\text { III:22) }\end{array}$ \\
\hline III:30 & $\begin{array}{l}\text { × (III:30 after } \\
\text { III:27) }\end{array}$ & & III:30 & $\begin{array}{l}\times(\text { III }: 30 \text { after } \\
\text { III:27) }\end{array}$ \\
\hline$x$ & III:36 & & $x$ & III:36 \\
\hline$\times$ & III:53 & & $x$ & III:53 \\
\hline$x$ & III:22 & & $x$ & III:22 \\
\hline$x$ & III:29 & & $x$ & III: 29 \\
\hline$x$ & III: 25 & & $x$ & III: 25 \\
\hline$\times$ & III: 27 & & $x$ & III:27 \\
\hline$\times$ & III:30 & & $x$ & III:30 \\
\hline$\times$ & III: 28 & & $x$ & III:28 \\
\hline III:31 & III:31 & & III:31 & $\begin{array}{l}\text { lacuna } \\
\text { III:30-IV:15 }\end{array}$ \\
\hline $\begin{array}{l}\times \text { (III:32 after } \\
\text { III:34) }\end{array}$ & III:32 & & III:32 & \\
\hline$x$ & III:37 & & $x$ & \\
\hline
\end{tabular}




\begin{tabular}{|c|c|c|c|c|}
\hline A610 & $\mathrm{C} 42$ & A146 & Acc22 & L1370 \\
\hline III:33 & III:33 & & III:33 & \\
\hline III:34 & III:34 & & III:34 & \\
\hline III:32 & $x$ & & $x$ & \\
\hline III:35 & III:35 & & III:35 & \\
\hline$x$ & III:38 & & $x$ & \\
\hline III:36 & $\begin{array}{l}\times(\text { III: } 36 \text { after } \\
\text { III:26) }\end{array}$ & & III:36 & \\
\hline III:37 & $\begin{array}{l}\times(\text { III: } 37 \text { after } \\
\text { III:32) }\end{array}$ & & III:37 & \\
\hline III:38 & $\begin{array}{l}\times(\text { IIII:38 after } \\
\text { III:35) }\end{array}$ & & III:38 & \\
\hline III:39-III:40 & III:39-III:40 & & III:39-III:40 & \\
\hline$x$ & III:44 & & $x$ & \\
\hline III:41-III:43 & III:41-III:43 & & III:41-III:43 & \\
\hline III:44 & $\begin{array}{l}\times(\text { III: } 44 \text { after } \\
\text { III: } 40)\end{array}$ & & III:44 & \\
\hline III:45 & III:45 & & III:45 & \\
\hline III:46 & $\begin{array}{l}\text { X (III:46 } \\
\text { omitted) }\end{array}$ & & III:46 & \\
\hline III:48 & $x$ & & III 48 & \\
\hline III:47 & III:47-ul & & III:47 & \\
\hline $\begin{array}{l}\times(\text { III: } 47 \text { after } \\
\text { III: } 48)\end{array}$ & III:48 & & $\begin{array}{l}\times(\text { III: } 47 \text { after } \\
\text { III: } 48)\end{array}$ & \\
\hline III:49 & III:49 & & III:49 & \\
\hline III:50 & $\begin{array}{l}\times(\text { III:50 after } \\
\text { III:51) }\end{array}$ & & III:50 & \\
\hline III:51 & III:51 & & III:51 & \\
\hline$x$ & III:50 & & $x$ & \\
\hline III:52 & III:52 & & III:52 & \\
\hline III:53 & $\begin{array}{l}\times(\text { III: } 53 \text { after } \\
\text { III:36) }\end{array}$ & & III:53 & \\
\hline III:54-III:64 & III:54-III:64 & & III:54-III:64 & \\
\hline IV:1-IV:8 & IV:1-IV:8 & \multirow[t]{2}{*}{ lacuna to VI:37 } & IV:1-IV:8 & \multirow[t]{2}{*}{ lacuna to IV:15 } \\
\hline IV:9 & $\begin{array}{l}\times(I V: 9 \text { after } \\
\text { IV:22) }\end{array}$ & & IV:9 & \\
\hline
\end{tabular}




\begin{tabular}{|c|c|c|c|c|}
\hline A610 & $\mathrm{C} 42$ & A146 & Acc22 & L1370 \\
\hline IV: 10 & IV:10 & & IV:10 & \\
\hline$x$ & IV:13 & & x & \\
\hline IV:11 & IV:11 & & IV:11 & \\
\hline IV:12 & IV:12 & & IV:12 & \\
\hline IV:13 & $\begin{array}{l}\times(I V: 13 \text { after } \\
\text { IV:10) }\end{array}$ & & IV:13 & \\
\hline IV:14 & IV:14 & & IV:14 & \\
\hline IV:15 & IV:15 & & IV:15 & \\
\hline$\times$ & IV:22 & & $x$ & \\
\hline$\times$ & IV:9 & & $\times$ & \\
\hline IV:16 & IV:16 & & IV:16 & IV:16 \\
\hline IV:17-IV:21 & IV:17-IV:21 & & IV:17-IV:21 & IV:17-IV:21 \\
\hline IV:22 & $\begin{array}{l}\times(I V: 22 \text { after } \\
\text { IV:15) }\end{array}$ & & IV:22 & $\begin{array}{l}\times(\text { IV: } 22 \text { after } 15 \\
\text { or omitted })\end{array}$ \\
\hline IV:23-IV:30 & IV:23-IV:30 & & IV:23-IV:30 & IV:23-30 \\
\hline IV:31 & $\begin{array}{l}\times(\mathrm{IV}: 31 \\
\text { omitted })\end{array}$ & & IV:31 & $\begin{array}{l}\times(\mathrm{IV}: 31 \\
\text { omitted })\end{array}$ \\
\hline IV:32-IV:64 & IV:32-IV:64 & & IV:32-IV:64 & IV IV:32-IV:64 \\
\hline $\mathrm{V}: 1-\mathrm{V}: 4$ & $\mathrm{~V}: 1-\mathrm{V}: 4$ & \multirow[t]{12}{*}{ lacuna to VI:37 } & V:1-V:4 & $\mathrm{V}: 1-\mathrm{V}: 4$ \\
\hline$\times(\mathrm{V}: 5$ omitted $)$ & V:5 & & V:5 & V:5 \\
\hline $\mathrm{V}: 6-\mathrm{V}: 27$ & V:6-V:27 & & V:6-V:27 & V:6-V:27 \\
\hline $\begin{array}{l}\times(\mathrm{V}: 27 \mathrm{bis} \\
\text { omitted })\end{array}$ & V:27bis & & V:27bis & V:27bis \\
\hline $\mathrm{V}: 28-\mathrm{V}: 31$ & $\mathrm{~V}: 28-\mathrm{V}: 31$ & & $\mathrm{~V}: 28-\mathrm{V}: 31$ & $\mathrm{~V}: 28-\mathrm{V}: 31$ \\
\hline$\times$ & $\mathrm{V}: 36$ & & $x$ & $\mathrm{~V}: 36$ \\
\hline $\mathrm{V}: 32-\mathrm{V}: 35$ & $\mathrm{~V}: 32-\mathrm{V}: 35$ & & $\mathrm{~V}: 32-\mathrm{V}: 35$ & $\mathrm{~V}: 32-\mathrm{V}: 35$ \\
\hline$\times(35 \mathrm{x}$ omitted $)$ & $\begin{array}{l}\times(\mathrm{V}: 35 \mathrm{x} \\
\text { omitted })\end{array}$ & & $\begin{array}{l}\times(V: 35 x \\
\text { omitted })\end{array}$ & $V: 35 x$ \\
\hline $\begin{array}{l}\times(35 \text { bis } \\
\text { omitted })\end{array}$ & V:35bis & & $\begin{array}{l}x(V: 35 \text { bis after } \\
V: 41)\end{array}$ & $V: 35$ bis \\
\hline$V: 36$ & $\begin{array}{l}\times(\mathrm{V}: 36 \text { after } \\
\mathrm{V}: 31)\end{array}$ & & V:36 & $\begin{array}{l}\times(\mathrm{V}: 36 \text { after } \\
\mathrm{V}: 31)\end{array}$ \\
\hline \multirow[t]{2}{*}{$\mathrm{V}: 37-\mathrm{V}: 41$} & $\mathrm{~V}: 37-\mathrm{V}: 41$ & & V:37-V:41 & V:37-V:41 \\
\hline & $\begin{array}{l}\times(35 \text { bis after } \\
\mathrm{V}: 35)\end{array}$ & & $\mathrm{V}: 35 \mathrm{bis}$ & $\begin{array}{l}\times(35 b i s \text { after } \\
V: 35 x)\end{array}$ \\
\hline
\end{tabular}




\begin{tabular}{|c|c|c|c|c|}
\hline A610 & $\mathrm{C} 42$ & A146 & Acc22 & L1370 \\
\hline $\mathrm{V}: 42-\mathrm{V}: 45$ & $\mathrm{~V}: 42-\mathrm{V}: 45$ & & $\mathrm{~V}: 42-\mathrm{V}: 45$ & V:42-V:45 \\
\hline$x$ & $x$ & & $x$ & $\mathrm{~V}: 50$ \\
\hline $\mathrm{V}: 46$ & $\mathrm{~V}: 46$ & & V:46 & $\times(\mathrm{V}: 46$ omitted $)$ \\
\hline $\mathrm{V}: 47$ & $\begin{array}{l}\times(V: 47 \text { after } \\
V: 49)\end{array}$ & & V:47 & $\begin{array}{l}\times(V: 47 \text { after } \\
V: 49)\end{array}$ \\
\hline$V: 48$ & V:48 & & V:48 & $\begin{array}{l}\times(V: 48 \text { after } \\
V: 47)\end{array}$ \\
\hline $\begin{array}{l}\times(48 b i s \\
\text { omitted })\end{array}$ & $\begin{array}{l}\times \text { (48bis } \\
\text { omitted) }\end{array}$ & & $V: 48$ bis & V:48bis \\
\hline $\mathrm{V}: 49$ & V:49 & & V:49 & $\mathrm{V}: 49$ \\
\hline $\mathrm{V}: 50$ & $\begin{array}{l}\times(V: 50 \text { after } \\
V: 47)\end{array}$ & & $\mathrm{V}: 50$ & $\begin{array}{l}\times(V: 50 \text { after } \\
V: 45)\end{array}$ \\
\hline$x$ & $\mathrm{~V}: 47$ & & $x$ & V:47 \\
\hline$x$ & $x$ & & $x$ & V:48 \\
\hline$x$ & V:50 & & x & $x$ \\
\hline $\mathrm{V}: 51$ & V:51 & & V:51 & V:51 \\
\hline VI:1-VI:8 & VI:1-VI:8 & \multirow[t]{16}{*}{ lacuna to VI:37 } & VI: 1-VI:8 & VI:1-VI:8 \\
\hline$x$ & $x$ & & VI:19-VI:20 & VI:19-VI:20 \\
\hline$x$ & $x$ & & VI:17-VI:18 & VI:17-VI:18 \\
\hline$x$ & $x$ & & VI: 15 & VI:15 \\
\hline VI:9 & VI:9 & & VI: 10 & VI:10 \\
\hline VI:10 & VI:10 & & VI:9 & VI:9 \\
\hline VI:11 & VI:11 & & VI: 11 & $\begin{array}{l}\times(\mathrm{VI}: 11 \text { after } \\
\text { VI:13) }\end{array}$ \\
\hline VI:12-VI:13 & VI:12-VI:13 & & VI:12-VI:13 & VI:12-VI:13 \\
\hline$\times$ & $x$ & & $x$ & VI:11 \\
\hline VI:14 & VI:14 & & VI: 14 & VI:14 \\
\hline$\times$ & $x$ & & $x$ & VI:23-VI:24 \\
\hline VI:28 & $x$ & & $x$ & $x$ \\
\hline VI:15 & VI:15 & & $\begin{array}{l}\times(V I: 15 \text { after } \\
\text { VI:18) }\end{array}$ & $\begin{array}{l}\times(V I: 15 \text { after } \\
\text { VI:18) }\end{array}$ \\
\hline$x$ & $x$ & & $\mathrm{VI}: 25$ & $x$ \\
\hline VI:16 & VI:16 & & VI:16 & $\begin{array}{l}\times(\mathrm{VI}: 16 \\
\text { omitted })\end{array}$ \\
\hline$x$ & $x$ & & VI:26 & $x$ \\
\hline
\end{tabular}




\begin{tabular}{|c|c|c|c|c|}
\hline A610 & $\mathrm{C} 42$ & A146 & Acc22 & L1370 \\
\hline VI:17-VI:18 & $\begin{array}{l}\times(\mathrm{VI}: 17-\mathrm{VI}: 18 \\
\text { after VI:20) }\end{array}$ & & $\begin{array}{l}\times(\mathrm{VI}: 17-\mathrm{VI}: 18 \\
\text { after VI:20) }\end{array}$ & $\begin{array}{l}\times(\mathrm{VI}: 17-V I: 18 \\
\text { after VI:20) }\end{array}$ \\
\hline VI:19-VI:20 & VI:19-VI:20 & & $\begin{array}{l}\times(\mathrm{VI}: 19-\mathrm{VI}: 20 \\
\text { after VI:8) }\end{array}$ & $\begin{array}{l}\times(\mathrm{VI}: 19-\mathrm{VI}: 20 \\
\text { after VI:8) }\end{array}$ \\
\hline$x$ & VI:17-VI:18 & & $x$ & $x$ \\
\hline VI:21-VI:22 & VI:21-VI:22 & & VI:21-VI:22 & $\begin{array}{l}\times(\mathrm{VI}: 21-\mathrm{VI}: 22 \\
\text { omitted })\end{array}$ \\
\hline VI:23-VI:24 & VI:23-VI:24 & & VI:23-VI:24 & $\begin{array}{l}\times(\mathrm{VI}: 23-\mathrm{VI}: 24 \\
\text { after VI:14) }\end{array}$ \\
\hline VI:25 & VI:25 & & $\begin{array}{l}\times(\mathrm{VI}: 25 \text { after } \\
\mathrm{VI}: 14)\end{array}$ & $\begin{array}{l}\times(\mathrm{VI}: 25 \text { after } \\
\mathrm{VI}: 29)\end{array}$ \\
\hline VI:26 & VI:26 & & $\begin{array}{l}\times(\mathrm{VI}: 26 \text { after } \\
\mathrm{VI}: 16)\end{array}$ & $\begin{array}{l}\times(\mathrm{VI}: 26 \text { after } \\
\mathrm{VI}: 25)\end{array}$ \\
\hline VI:27 & VI: 27 & & VI:27 & VI:27 \\
\hline $\begin{array}{l}\times(\mathrm{VI}: 28 \text { after } \\
\text { VI:14) }\end{array}$ & VI:28 & & VI: 28 & VI:28 \\
\hline VI:29 & VI:29 & & VI:29 & VI:29 \\
\hline$\times$ & $x$ & & $x$ & VI:25 \\
\hline$x$ & $x$ & & $x$ & VI:26 \\
\hline VI:30-VI:36 & VI:30-VI:36 & & VI:30-VI:36 & VI:30-VI:36 \\
\hline VI:37-VI:44 & VI:37-VI:44 & VI:37-VI:44 & VI:37-VI:44 & VI:37-VI:44 \\
\hline $\begin{array}{l}\times(44 \mathrm{bis} \\
\text { omitted })\end{array}$ & VI:44bis & VI:44bis & VI:44bis & VI:44bis \\
\hline VI:45-VI:54 & VI:45-VI:54 & VI:45-VI:54 & VI:45-VI:54 & VI:45-VI:54 \\
\hline VI:56 & VI:55 & VI:55 & VI:56 & VI:55 \\
\hline VI:55 & VI:56 & VI:56 & VI:55 & VI:56 \\
\hline VI:57-VI:58 & VI:57-VI:58 & VI:57-VI:58 & VI:57-VI:58 & VI:57-VI:58 \\
\hline
\end{tabular}




\title{
Om Taustaven fra Pingvellir, Island Skálholtbispen Ísleifur Gissurarsons hyrdestav?
}

\author{
Lise GJEDSsø BERTELSEN
}

\section{Indledning}

Den 24. maj 1957 blev et usædvanligt fund gjort på hjemmemarken til Pingvellirgården ved det historiske Altings mødested på Pingvellir i det sydvestlige Island ca. 40 km øst for Reykjavík. På det tidspunkt var Dr. Kristján Eldjárn direktør for Pjóðminjasafn Íslands/Islands Nationalmuseum, som han havde været med til at grundlægge i 1945. Kristján Eldjárn var uddannet arkæolog fra Københavns Universitet, specialist i vikingetid og Dr. Phil. i 1956 fra Háskóli Íslands/Islands Universitet med afhandlingen "Kuml og haugfé úr heiðnum sið á Íslandi“ (Eldjárn 1956). I 1968 blev Dr. Eldjárn sit lands tredje præsident, et embede han beklædte til sin død i 1980. For ca. 50 år siden publicerede Kristján Eldjárn topstykket af den formodentlige bispestav dels på islandsk (fig. 1) og dels på dansk (Eldjárn 1971a, s. 5-27; Eldjárn 1971b, s. 65-81). ${ }^{1}$ Sidstnævnte var påkrævet, eftersom ikke så mange læsere forstår islandsk. Nu er tiden kommet til at følge op på Eldjárns resultater med en ny artikel endnu en gang på islandsk så vel som på dansk. Den 12. februar 2020 fyldte arkæolog Mjöll Snæsdóttir, Reykjavik, 70 år, hvilket fejredes med et festskrift til hendes ære. Bogens titel er "Minjaping - helgað Mjöll Snæsdóttur á sjötugsafmæli hennar 12. febrúar 2020”, og mit bidrag hertil var kapitlet "Um tá-bagalinn frá Pingvöllum. Hirðisstafur Ísleifs Gissurarsonar Skálholtsbiskups?” Mit kapitel var skrevet på dansk og derpå oversat

${ }^{1}$ Begge artikler er nævnt i Gylfi Gröndals bog "Kristján Eldjárn. Ævisaga”, 1991, s. 380.

Bertelsen, Lise Gjedssø. 2020. Om Taustaven fra Pingvellir, Island:

Skálholtbispen Ísleifur Gissurarsons hyrdestav?

Scripta Islandica 71: 99-121.

(C) Lise Gjedss $\varnothing$ Bertelsen (CC BY)

DOI: $10.33063 /$ diva-429321 


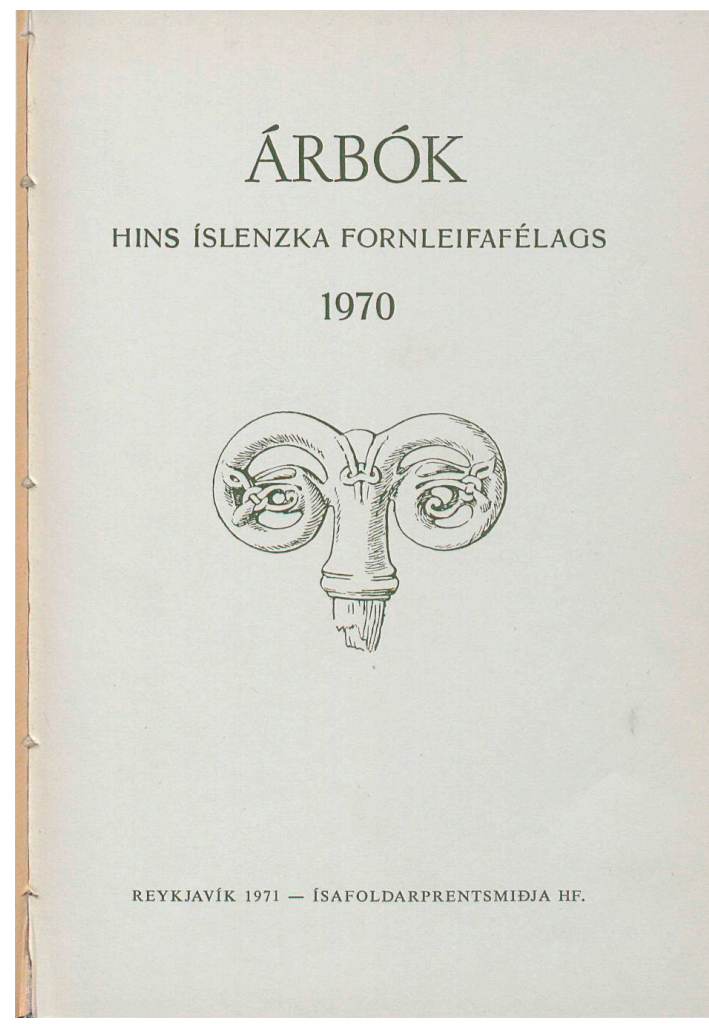

Fig. 1. Forsiden af Árbók Hins íslenzka fornleifafélags 1970 (Eldjárn 1971a) udsmykket med tegning af topstykket af bronze, formodentlig fra en bispestav, fundet på Pingvellir i det sydvestlige Island. Max bredde tværs over krogene $8,6 \mathrm{~cm}$. Pjóðminjasafn Íslands/Islands Nationalmuseum inventarnummer Pjms 15776.

til islandsk af Guðmundur Ólafsson, forhenværende overinspektør ved Pjóðminjasafn Íslands/Islands Nationalmuseum. Kapitlet her i Scripta Islandica er således den oprindelige tekst og en anelse længere, eftersom nogle oplysninger i den islandske oversættelse ville være overflødige oplysninger for islandske læsere.

Pingvellirgården har været bebygget siden vikingetiden og spillede en rolle i forbindelse med tingstedet (Eldjárn 1971a, s. 5; Eldjárn 1971b, s. 65). Under gravearbejde i forbindelse med nedlæggelse af et kabel fandt man $43 \mathrm{~cm}$ under jordoverfladen et lille udsmykket plastisk topstykke af bronze formodentlig af en bispestav med en rest af sin træstav siddende i topstykkets dølle; der fandtes ingen spor af forgyldning. Topstykket har 
i dag en mørkegrøn patina. Jordlaget indeholdt tillige trækulsstumper og nogle arrangerede sten.

Topstykket fra Pingvellir har - som flere andre topstykker til bispestave samt en speciel type kors - form som bogstavet T, der i det oldgræske alfabet kaldtes tau. De er dermed navngivet efter deres udseende, hvorfor de benævnes henholdsvis Taustave og henholdsvis Taukors. Inden for kristendommen er bispens stav (latin: baculus episcopalis) hans magt- og værdighedstegn. Den har oftest form som en krumstav med én krog, men dens topstykke kan som allerede nævnt også have form som et $\mathrm{T}$ eller for eksempel et kors eller krucifiks. Bispestaven er en symbolsk hyrdestav, der viser biskoppen i sin egenskab af hyrde for sit stift, således som også Kristus selv er den gode hyrde i følge Det Nye Testamentes Johannesevangelium kapitel 10 vers 11-16. Bispestave kan være udarbejdet i mange forskellige materialer som for eksempel metal (Eldjárn 1971a, s. 20, fig. 10; Eldjárn 1971b, s. 75, fig. 9), elfenben (Eldjárn 1971a, s. 22, fig. 12; Eldjárn 1971b, s. 77, fig. 11) og hvalrostand (Eldjárn 1971a, s. 21, fig. 11; Eldjárn 1971b s. 76, fig. 10). Eller de kan være afbildet eksempelvis i illuminerede manuskripter (fig. $7 \mathrm{~b}$ midtfor) eller på stenmonumenter som en irsk korsplade (Eldjárn 1971a, s. 17, fig. 7) og irske højkors (Eldjárn 1971a, s. 18, fig. 8 og s. 19, fig. 9; Eldjárn 1971b, s. 73, fig. 7 og s. 74, fig. 8).

I sin islandske og sin danske publikation fastslog Eldjárn topstykkets stilistiske tilhørsforhold til Urnesstilen, daterede det til tredje fjerdedel af 1000-tallet uden nærmere bevisførelse og foreslog, at bispestaven muligvis kunne have tilhørt Islands første katolske biskop Ísleifur Gissurarson på gården Skálholt i det sydvestlige Island (ikke langt fra Pingvellir), eftersom han var biskop dér i perioden 1056-1080 (Eldjárn 1971a; Eldjárn 1971b). Men efter Eldjárns publiceringer fra for snart 50 år siden er der sket meget nyt inden for forskningen i de sene vikingetids stile, hvoraf Urnesstilen er den yngste. I det følgende vil topstykkets udsmykning blive analyseret, og vi skal se, om resultatet heraf vil understøtte Eldjárns datering af genstanden til tredje fjerdedel af 1000-tallet og hans forslag om tilhørsforholdet til Islands første katolske biskop eller ikke.

\section{En bisp, et bispesæde ...}

Ca. år 1000 var kristendommen blevet vedtaget på Altinget som Islands officielle religion, og i 1056 fik landet sin første katolske biskop, Ísleifur 


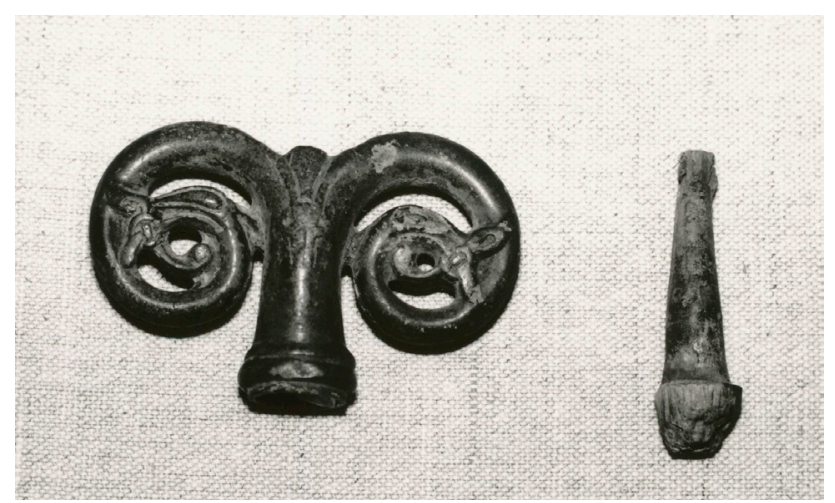

Fig. 2. Topstykket af bronze formodentlig af en bispestav med en rest af sin stav af træ (her udtaget). Fundet på Pingvellir i det sydvestlige Island. Max bredde tværs over krogene $8,6 \mathrm{~cm}$. Pjóðminjasafn Íslands/Islands Nationalmuseum inventarnummer Pjms 15776. Foto: Lise Gjedssø Bertelsen 1988.

Gissurarson. Han var født ca. 1006 som søn af storbonden Gissur "den Hvide" Teitsson, der aktivt havde støttet Islands antagelse af kristendommen, og Pórdís Póroddsdóttir. Ísleifur studerede teologi i Herford i Tyskland og blev bispeviet i Bremen den 4. juni 1055 af ærkebiskop Adalbert af bispedømmet Hamburg-Bremen, som på den tid omfattede det meste af Nordtyskland samt de skandinaviske lande. Derefter rejste Ísleifur hjem til Island med fuldmagt til at styre landets kirke og kristenliv. Endnu var der ikke noget fast bispesæde, men han slog sig ned på sin fædrene gård Skálholt. Og eftersom det var biskoppens ansvar at uddanne landets nye gejstlige, grundlagde han en højt estimeret latinskole, som kan følges direkte frem til nutidens gymnasium Menntaskólinn í Reykjavík (MR), der er en af landets ældste institutioner. Skálholt skolen blev i 1786 - efter et stort jordskælv i 1784 og nedlæggelse ved kongelig resolution i 1785 - flyttet til Reykjavik, derpå i 1805 til Bessastaðir og i 1846 tilbage til Reykjavik til sin nuværende bygning på Pingholtsstræti i Reykjavík.

Ísleifur efterfulgtes i embedet af sønnen Gissur Ísleifsson (levetid ca. 1042-1118) (biskop 1082-1118), der som sin far havde studeret i Tyskland. Gissur var i udlandet, da faderen døde, men kom hjem sommeren efter, blev valgt til biskop efter sin far og bispeviet den 4. september 1082 i Magdeburg i Tyskland af Hartwig af Spanheim, ærkebiskop af Magdeburg (ærkebiskop 1079-1102). Som biskop styrkede Gissur i høj grad kirken, ikke mindst da han i 1096 skænkede sin slægts hovedsæde Skál- 


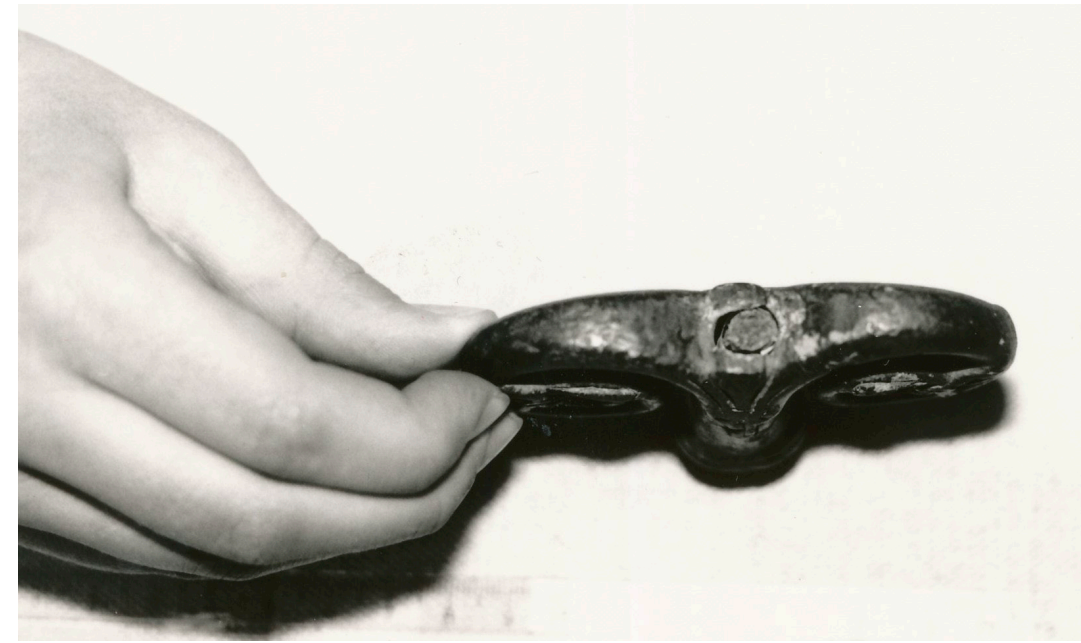

Fig. 3. Topstykket af bronze formodentlig af en bispestav set fra oven. Gennem åbningen i midten ses kilen af fyrretræ. Fundet på Pingvellir i det sydvestlige Island. Max bredde tværs over krogene $8,6 \mathrm{~cm}$. Pjóðminjasafn Íslands/Islands Nationalmuseum inventarnummer Pjms 15776. Foto Lise Gjedss $\varnothing$ Bertelsen 1988.

holt med tilhørende jorder til oprettelsen af et fast bispesæde dér. Og med udgangspunkt i en folketælling fik han sammen med flere i 1096 indført tiende i landet. Tiende er en afgift for verdslige folk på $10 \%$ af deres indtægter i skat til kirken, hvilket førte til økonomisk og kulturel fremgang ikke mindst for Skálholt. Han lod også bygge en katedral, som var viet til apostlen Peter. Skálholt var katolsk bispesæde frem til reformationen i 1550, hvorefter det blev omdannet til luthersk sæde, som fungerede frem til 1796, hvor det blev flyttet til Reykjavík.

\section{... og en bispestav}

Det lille plastiske topstykke fra Pingvellir er elegant og dygtigt udført. Det består af en dølle i midten (genstandens rygrad) med det såkaldte sløjfemotiv på for- og bagsiden. To stort set symmetriske kroge, der hver gengiver hoved og hals af en slange, løber fra døllen ud til hver sin side (fig. 2). Topstykket er støbt med perforeringer. I døllen sidder en rest af 


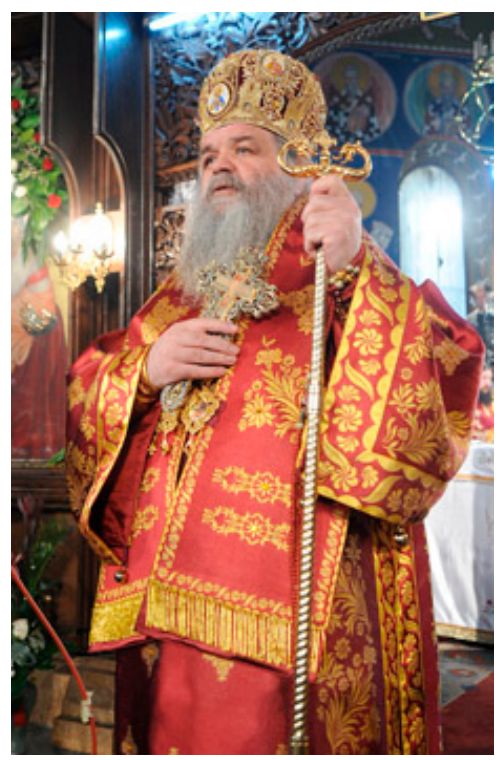

Fig. 4. Ærkebiskop Stefan, overhoved for den makedonske ortodokse kirke, med Taustav med kors. Foto: Premin Portal, uploaded from Macedonian Wikipedia, original uploader: User:Macedonian (GFDL, via Wikimedia commons).

stavens træ af Rød Kornel (Cornus sanguinea L.) samt øverst ned heri en kile af fyrretræ (Eldjárn 1971a, s. 7, fig. 3; Eldjárn 1971b, s. 67, fig. 4). Stavens oprindelige længde kendes ikke. Sløjfemotivet, undertiden kaldet irsk kobbel, i lavt relief på døllen sammenholder de to slanger. Døllen har på toppen en lille rundet og ujævn åbning ned til fyrrekilen (fig. 3). Denne åbning må oprindelig have været lukket, eventuelt med en nu tabt lille bronzeplade eller en plastisk figur måske af form som et lille kors, som vi kender det for eksempel på overhoved for den makedonske ortodokse kirke, ærkebiskop Stefans Taustav (fig. 4). Bredden tværs hen over topstykket fra Pingvellirs kroge er $8,6 \mathrm{~cm}$.

\section{Analyse af topstykket til Taustaven fra Pingvellirs stilistiske tilhørsforhold}

Kristján Eldjárn fastslog korrekt, at topstykket af Taustaven fra Pingvellir tydeligvis er udsmykket i Urnesstil, men sammenlignede det derefter ikke 

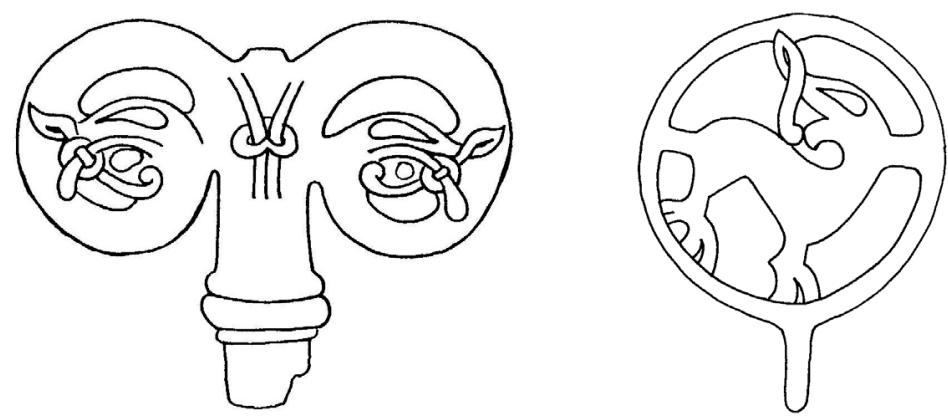

Fig. 5a (til venstre): Topstykket af bronze af den formodede bispestav fra Pingvellir, Island. Urnes stilgruppe Pr 3. Max bredde tværs over krogene 8,6 cm. Pjms 15776.

Fig. 5b (til højre): Ålborggruppefibel/dyrefibel uden dyreslyng, Danmark. Urnes stilgruppe Pr 3. Cirklens diameter $2 \mathrm{~cm}$. Tegninger: Lise Gjedss $\varnothing$ Bertelsen.

helt logisk især med udsmykkede genstande i Ringerikestil og vurderede, at få eksempler var bedre til sammenligning end dyrene på G 113 Ardre III stenen fra Gotland (Eldjárn 1971a, s. 11 og s. 12, fig. 4; Eldjárn 1971b, s. 70 og s. 71, fig. 5). Urnesstilen var den yngste af den sene vikingetids kunsts tre stile: Mammen, Ringerike og Urnes, og den var den dominerende stil i vikingernes verden i 1000-tallets anden halvdel og løbende frem til ind i anden fjerdedel af 1100-tallet (Bertelsen 2002, s. 27 ff. og s. 65 ff.). Stilen var udsprunget af og nært knyttet til sin forgænger Ringerikestilen, men distanceret herfra ved markante ændringer i forhold til denne.

Enhver genstand skal ses i rette kontekst og dens stil, motiv/-er og billedstruktur analyseres nøje (Bertelsen 2002, s. 16 ff.; Bertelsen 2006, s. 32 ff.). Med stil forstås det design, som kendetegner en kunstners eller en kunstepokes værker i samtlige deres udformninger. Den sene vikingetids kunst var nordisk stil/design med overvejende kristent indhold. Urnesstilen favoriserede slanke, organiske former med en dynamisk vekslen mellem brede og smalle bånd, og den tilstræbte igen og igen plastisk effekt, hvilket lagde afstand til Mammen- og Ringerikestilenes fladebindende træk som for eksempel disses kompakte former, store snært oprullede ledspiraler og dobbeltkonturer. Urnesstilens dyr har lange, smalle halse, der går direkte over i hovederne, som er langstrakte og gradvist smalner til fremefter og ender i en spids snude med elegant snudesnip; øjet er dråbeformet (mandelformede øjne er karakteristiske for Ringerikestilen) (Bertelsen 1994, s. 64 ff.). Runde øjne kan dog ses i alle tre stile. 

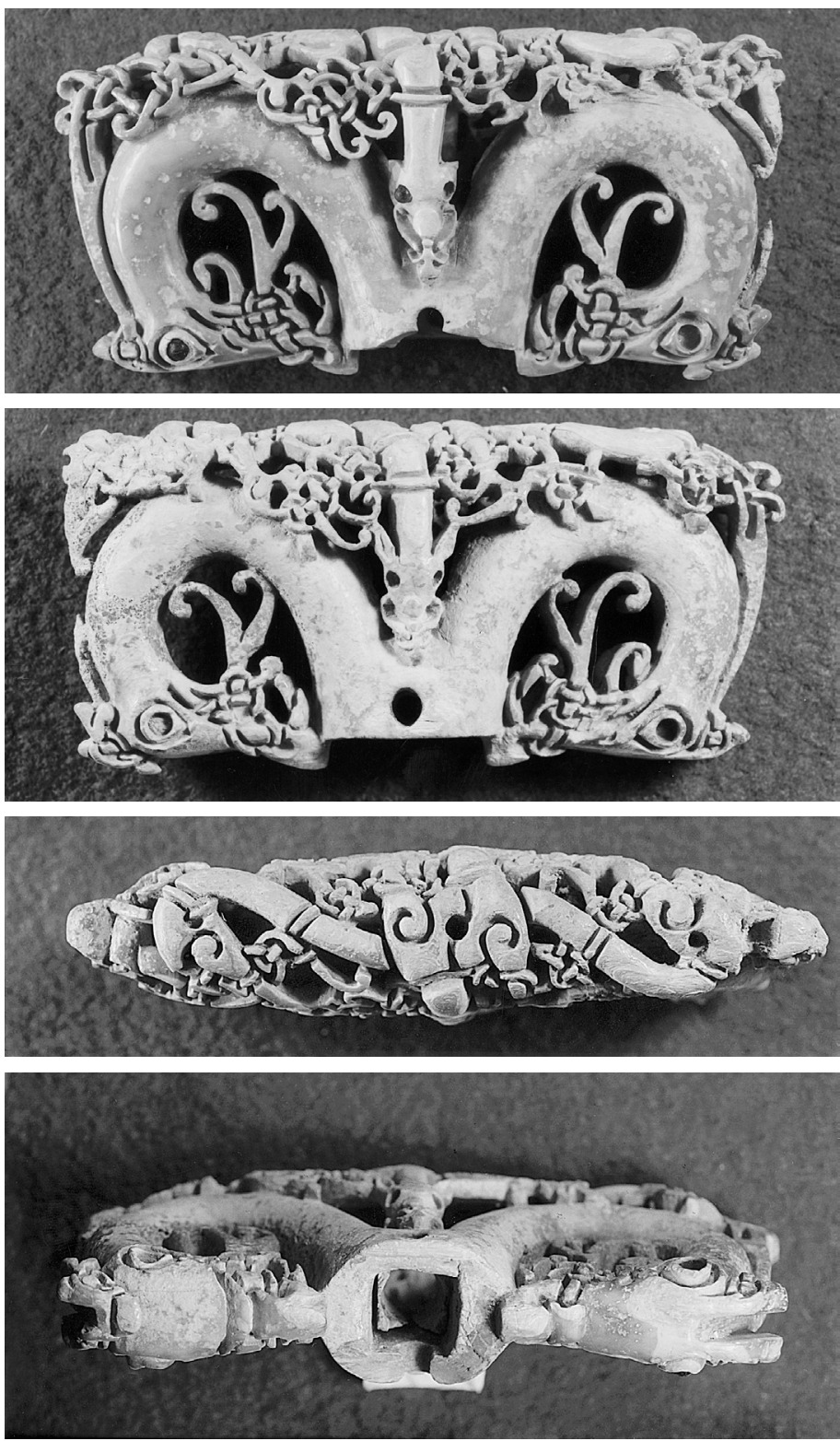

Fig. 6a, b, c, d (fra siderne samt fra top til bund). Topstykke af bispestav af hvalrostand fra gravområde i forbindelse med Veszprémvölgy klosteret i Veszprém, Ungarn. Urnes stilgruppe Pr 3. Max bredde hen over krogene 9,8 cm. Skandinavisk arbejde. Fotos: Pál Kénez. 
I 1990'erne etablerede professor Anne-Sofie Gräslund ved Uppsala universitet en nu alment anerkendt og anvendt stilistisk typologi og datering for sen vikingetids billedrunestens ornamentik (Gräslund 1992), som også kan anvendes på samtidige udsmykninger på andre materialer og formater. Af Gräslunds opstillede stilgrupper er det én af de såkaldte fem Profilstile (benæunt $\operatorname{Pr} 1, \operatorname{Pr} 2, \operatorname{Pr} 3, \operatorname{Pr} 4$ og $\operatorname{Pr} 5$ ), der er aktuel for topstykket fra Pingvellirs vedkommende, det hører til i stilgruppe Pr 3 , hvilket daterer det til Islands første katolske biskops tid (fig. 5a til venstre) (Gräslund 1992, s. 177 ff.; Gräslund 2006, s. 133, fig. 2). Benævnelsen Pr er en forkortelse af ordet profil og hentyder til, at disse billedrunestens skriftbånd er udformet som runeslanger med profilsete hoveder med et dråbeformet $\varnothing$ je synligt. Stilene Pr 1 og Pr 2 modsvarer Ringerikestilen og dateres til henholdsvis ca. 1010-1040 og ca. 1020-1050, mens Pr 3, Pr 4 og Pr 5 er tre faser af Urnesstilens udvikling og dateres til henholdsvis ca. 1045-1075, ca. 1070-1100 og ca. 1100-1130 (Gräslund 2006, s. 126). Repræsentative eksempler på typiske Pr 3 billedrunesten i Uppland er opremset hos Gräslund (Gräslund 1992, s. 184; Gräslund 2006, s. 122).

Blandt miniaturegengivelserne, som passer ind i Urnes stilgruppe Pr 3 , kan for eksempel nævnes Ålborg-gruppens fibulaer (fig. 5b til højre) (Bertelsen 1992, s. 237 ff.) og topstykket af en Tauformet bispestav fra et nu forstyrret gravområde ved Veszprémvölgy klosteret i Ungarn (fig. 6a-d) (Fülöp og Koppány 2004, s. 121 ff.). Motivet på Ålborg-gruppens fibulaer er et firbenet dyr placeret i en cirkelrund ramme, men fra Krammark i Sønderjylland, Danmark, kendes et eksemplar med akanthuspalmetter arrangeret i korsform uden på rammen (Bertelsen 1992, s. 256, katalognummer 11). Disse fibulaer har ikke dyreslyng. Materialet synes altovervejende at være kobberlegering.

Det bevarede topstykke af den Tauformede bispestav fra et dårlig bevaret gravområde i forbindelse med Veszprémvölgy klosteret, Veszprém, Ungarn er af hvalrostand, måler $9,8 \mathrm{~cm}$ i bredden, er poleret og af skandinavisk arbejde. De to næsten symmetriske kroge, der hver gengiver hoved og hals af en slange, danner de horisontale grene af Tauformen og forenes i døllen, lige som det er tilfældet med topstykket fra Pingvellir. Fra slangernes overkæber samt nakketoppe udgår overdådige akanthusslyng. Slangerne har spidse tænder i over- og underkæber. Øverst på topstykket ligger to langstrakte båndformede firbenede dyr, hvis hoveder ser ned midt imellem de to kroge. Dyrenes øjne var oprindelig indlagt med glas, der er bevaret få mørkeblå glasindlæg. 

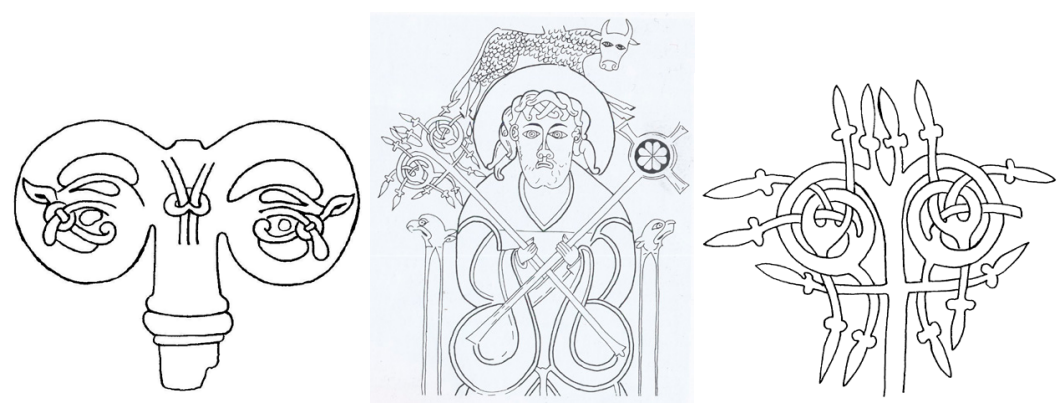

Fig. 7a (til venstre): Topstykket af den formodede bispestav fra Pingvellir, Island. Urnes stilgruppe Pr 3. Pjms 15776.

Fig. 7b (midtfor): Sankt Lukas Evangelisten siddende med to insignier: en Taustav og en korsstav. Hans symbol, oksen, ses over hans hoved. Forsideillustration til Sankt Lukas evangeliet i Sankt Chads evangeliar fra ca. 730. Lichfield Cathedral, England. Tegning fra Gotfredsen og Frederiksen 2003: 103, fig. 69.

Fig. 7c (til højre): Detalje af Sankt Lukas Evangelistens Taustav. Tegninger til venstre og til højre: Lise Gjedssø Bertelsen.

\section{Analyse af topstykket til Taustaven fra Pingvellirs motiver}

Et motiv er en synlig og genkendelig afbildning af en eller flere figurer og enkeltheder, som udgør en helhed, hvis udførelse afstikkes af stilen. På topstykket fra Pingvellir udgøres de bevarede motiver af to sløjfelignende figurer set en face (en på forsiden og en på bagsiden af døllen) og to slanger set i profil, som danner de plastiske kroge (fig. 7a til venstre). Måske kan der tillige have været tale om en mindre figur til at lukke det ujævne hul på toppen mellem de to kroge?

Sløjfemotivet er som en lås, og på topstykket fra Pingvellir samler det de to slanger til én slange i døllen. Men motivet kan også sammenholde andre figurer, og det optræder ofte som en pars pro toto (latin: 'en del af helheden'), hvilket vil sige, at en helhed repræsenteres af en del heraf. Sløjfemotivet kan på ingen måde affærdiges som et ornament uden betydning. Lige som akanthusbladet er sløjfemotivet en hyppig pars pro toto for og symbol på det kristne livets træ i sen vikingetids kunst og i den romanske kunst (Gotfredsen og Frederiksen 2003, s. 124). Sløjfemotivet på billedrunesten som for eksempel den bornholmske 

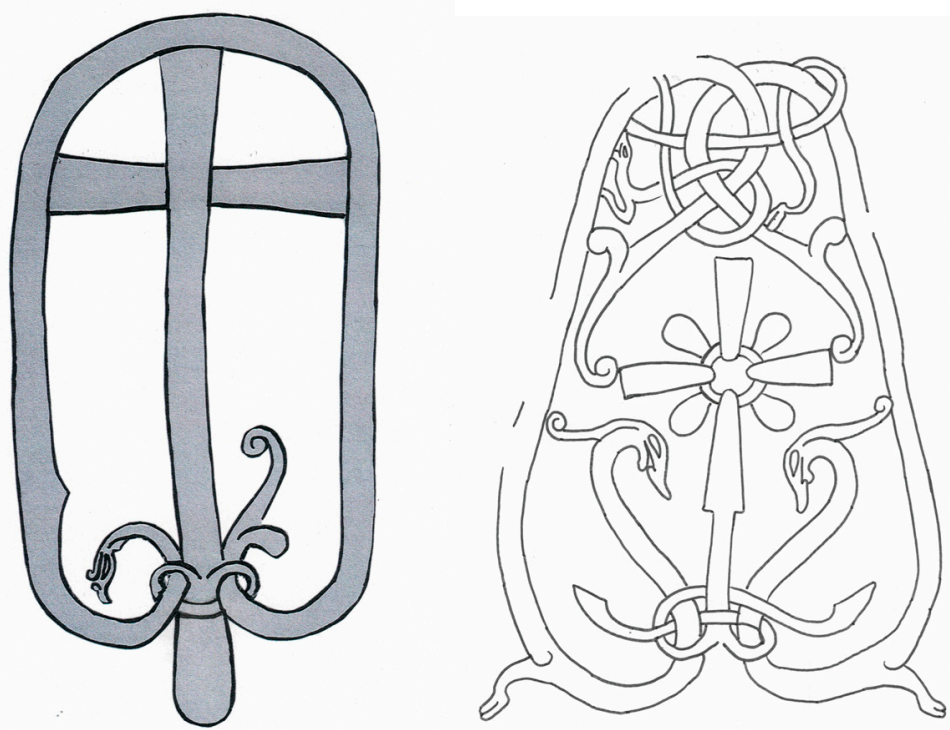

Fig. 8a (til venstre): DR 379/Bh 33 Nylarsker-sten 1, Bornholm, Danmark.

Fig. 8b (til højre): U 873 Örsunda, Gryta sogn, Uppland, Sverige. Begge Urnes stilgruppe $\operatorname{Pr} 3$. Runetekst på den bornholmske stens kors samt begge stens slangers kroppe er udeladt. Tegninger: Lise Gjedss $\varnothing$ Bertelsen.

DR 379/Bh 33 Nylarsker-sten 1, Danmark (fig. 8a til venstre) og den svenske U 873 Örsunda sten, Gryta sogn, Uppland (fig. 8b til højre), begge udsmykket i Urnes stilgruppe Pr 3, demonstrerer tydeligt dette. På førstnævnte sten udspringer sløjfen direkte fra korsets stamme, og på sidstnævnte dannes den direkte af livstræsringkorsets rødder. Teksten på DR 379/Bh 33 Nylarsker-sten 1 lyder: "Sasser lod rejse stenen efter sin fader Alvard; han druknede ude med hele skibsmandskabet. Krist hjælpe hans sjæl evigt uden ende(?). Denne sten skal stå efter (dvs. til minde)" (Imer og Fortuna 2016, s. 307). Teksten på U 873 Örsunda stenen lyder: "Tingfast lod rejse denne sten efter Holmger, sin gode fader, Ingas mand. Gud hjælpe hans sjæl. Balle ristede denne sten" (Wessén og Jansson 1949-51, s. 545).

Og efter at have optrådt hyppigt på især midtsvenske, men også på for eksempel gotlandske og bornholmske billedrunesten og på metalarbejder som for eksempel sølvskålen fra Lilla Valla (Karlsson 1981, s. 92, fig. 2) samt to dåseformede fibulaer, alle tre genstande fra Gotland (Karlsson 

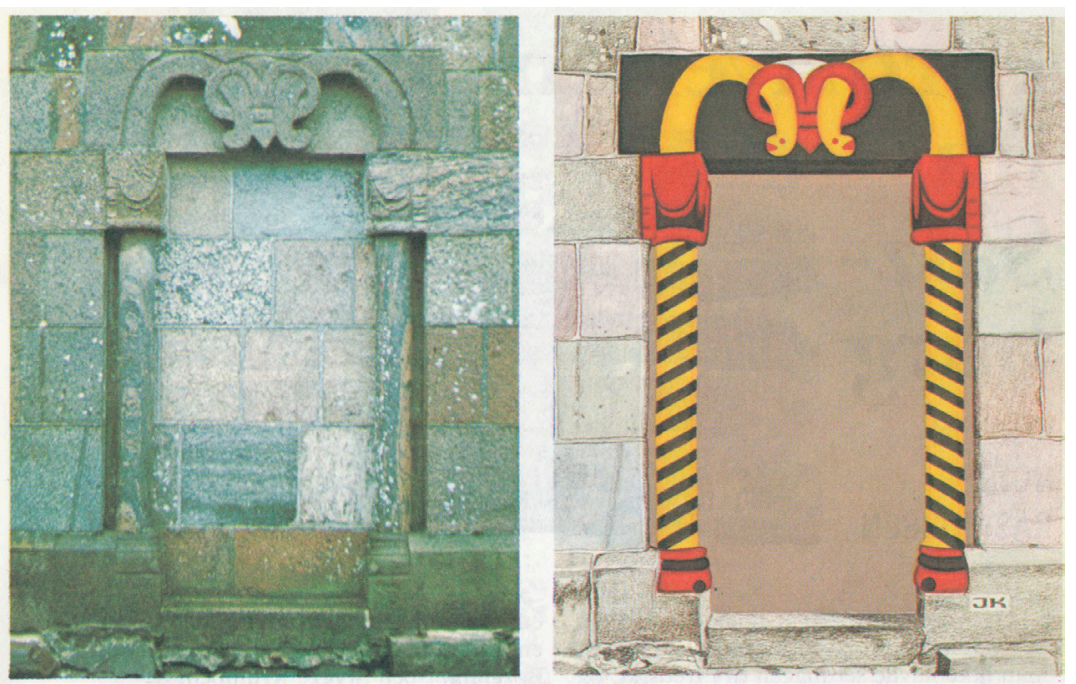

Fig. 9a (til venstre): Tilmuret nordportal i Lem kirke, Danmark.

Fig. 9b (til højre): Samme portal med farver som den kan have set ud oprindeligt. Fotos fra Vellev 1981a, s. 17.

1981, s. 103, fig. 27), fortsætter motivet i den romanske kunst på stavkirker. Det gælder for eksempel portalen fra Hopperstad ved Sognefjorden i Norge (Vellev 1981a, s. 16; Vellev 1981b, s. 19, fig. 10-11) og på en række portaloverliggere, kaldet sløjfeportaler, på sognekirker i omegnen af Randers i Danmark (Gotfredsen og Frederiksen 2003, s. 123 ff.; Vellev 1981a, s. 16f.; Vellev 1981b, s. 9ff.) (fig. 9a til venstre og fig. 9b til højre). Her fremgår det tydeligt af portalen med farver (fors $\emptyset \mathrm{g}$ i nutiden) (fig. 9b til højre), at sløjfen efter al sandsynlighed sammenholder to bispestave/ krumstave med hver én krog over kirkens indgang (Gotfredsen og Frederiksen 2003, s. 125). Valg af farver er gjort på baggrund af rester af bemaling på billedrunesten og Hørningplanken fra Hørning kirke i Jylland $^{2}$ ikke langt fra Lem.

Og på det udskårne fragment af en portaloverligger/planke af egetræ fra

\footnotetext{
${ }^{2}$ Hørningplanken fra Hørning kirke sydøst for Randers var oprindelig en del af et hammerbånd fra en tidlig stavkirke på stedet og er dendrokronologisk dateret til ca. 1070. Et hammerbånd fastholdt øverst i en stavvæg dennes lodrette planker. Hørningplanken har farverester bevaret både på motiver på yder- og indersiden, førstnævnte er udsmykket i Urnesstil, sidstnævnte i Romansk stil. Danmarks Nationalmuseum inventarnummer NM II D 2309.
} 


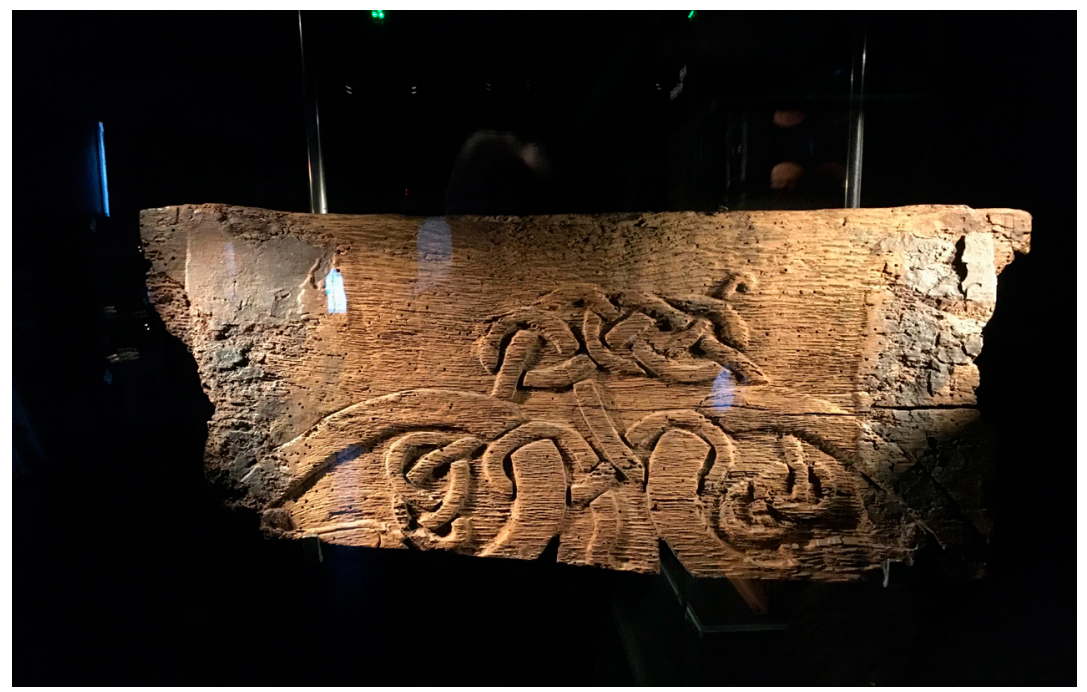

Fig. 10. Brågarp planken, Brågarps kirke, Staffanstorps kommune, Skåne. Lunds Universitets Historiska Museum inventarnummer 28733a. Urnes stilgruppe Pr 4. Foto: Jes Wienberg 2020.

Brågarps kirke, Staffanstorps kommune, Skåne ser vi to modsat stillede slangehoveder arrangeret næsten som dem på Taustaven fra Pingvellir (fig. 10) (Bertelsen 2002, s. 65, katalognummer 32 med tegning; Gotfredsen og Frederiksen 2003, s. 123, fig. 85). Fragmentet måler $97 \mathrm{~cm}$ i bredden, $40 \mathrm{~cm}$ i højden og $6 \mathrm{~cm}$ i tykkelsen. Det blev fundet i 1941 i kirken, og stammer sandsynligvis fra en tidligere stavkirke, en forgænger for den nuværende kirke. Brågarps portaloverligger/planke har på Lunds Universitets Historiska Museum inventarnummer 28733a, men en afstøbning er udstillet i kirken (https://www.svenskakyrkan.se/ststaffan/bragarpskyrka). Overliggerens/plankens udsmyknings stilistiske tilhørsforhold er Urnesstilens Pr 4, som er dateret til ca. 1070-1100. På topstykket fra Pingvellir er de to slanger samlet til én slange i døllen ved hjælp af det hellige sløjfemotiv som en lås, mens de to slanger på Brågarp portaloverliggeren/planken er sammenholdt ved hjælp af den heraldisk højre slanges lange nakketop arrangeret horisontalt $i$ et ottetalsslyng omkring deres halse. Og vi husker, at ottetallet i kristendommen symboliserer dåbens og opstandelsens tal, selv i dag symboliserer det liggende ottetal i matematikkens sprog "det uendelige" (Gotfredsen og Frederiksen 2003, s. 54). 
Slangen er et af de ældste symboler i menneskenes symbolverden og et af de mest benyttede motiver gennem tiderne i mange kulturer også i sen vikingetids kunst. Slangen er et kraftfuldt ambivalent symbol, der spænder fra at være "en god gud" til at være "en ond djævel”. Snart er den et stærkt positivt livssymbol, et kosmossymbol, som repræsenter evigt liv, genfødsel, visdom, helbredelse og klogskab, snart er den et stærkt negativt dødssymbol, et kaossymbol, som repræsenterer undergang, død, ondskab og listighed, snart rummer den begge dele. De to slanger, der udgør krogene på Pingvellir topstykket, og som forenes til én slange i døllen knyttet sammen af de to sløjfemotiver, signalerer kraftfuldt motivets dualisme. Og slangens kosmiske dimensioner forstærkes, når den danner cirkler som på krogene. Cirklen, der ikke har hverken begyndelse eller afslutning, symboliserer frem for alt evighed; derfor har vi i dag forlovelses- og vielsesringe, ligesom vi sender en krans til begravelsen.

Hvorfor blev slangen så dominerende rent ikonografisk for eksempel i vikingernes kunst, for der er ikke mange slanger i Norden, og i den nordiske mytologi er der kun få navngivne slanger (for eksempel Fafner, Nidhug og Midgårdsormen). Det er vanskeligt at svare på, men slangen er sandsynligvis i menneskets psyke en arketype/et urbillede/en del af vores arvemasse; den appellerer til menneskets fantasi og symboldannelse, og dens krop har en facon, som let lader sig gengive lige fra som en lige linje til en cirkel, spiral, et 8-tal eller lignende. Vi er i dag i religiøs henseende opdraget med den protestantisk kristne/Det Ny Testamentes opfattelse af slangen som værende entydig ond, hvorved vi bevidst eller ubevidst let kommer til at læse vores egen tids tolkning af symbolet ind i motivet. Missionstidens mennesker derimod levede med den katolsk kristne/Det Gamle Testamentes opfattelse af slangen som værende vis og snedig. Men også vi i dag træffer på den positive slange for eksempel i form af den kloge og helbredende Æskulapslange, som udgør grundstammen i snart sagt ethvert logo inden for læge- og medicinalverdenen.

Allerede i fortællingen i det gamle babylonisk-assyriske Gilgameshepos fra det tredje årtusinde før Kristi fødsel berettes om slangens og livets plantes nære samhørighed. Her fortælles, at slangen fik evigt liv efter, at den havde spist den søplante, som ejede det evige liv. Og at slangen ejer evigt liv demonstreres ved dens hamskifte, hvor den fødes på ny igen og igen. Ældst kendte afbildning af fortællingen om slangen, der spiste nævnte søplante, ses muligvis på et mesopotamisk bæger fra o. 2500 før Kristi fødsel. Fra Mesopotamien spredte myten om den helbredende og livsfornyende slange sig til Ægypten, Grækenland, Rom og videre til os (Bertelsen 2015, s. 58 


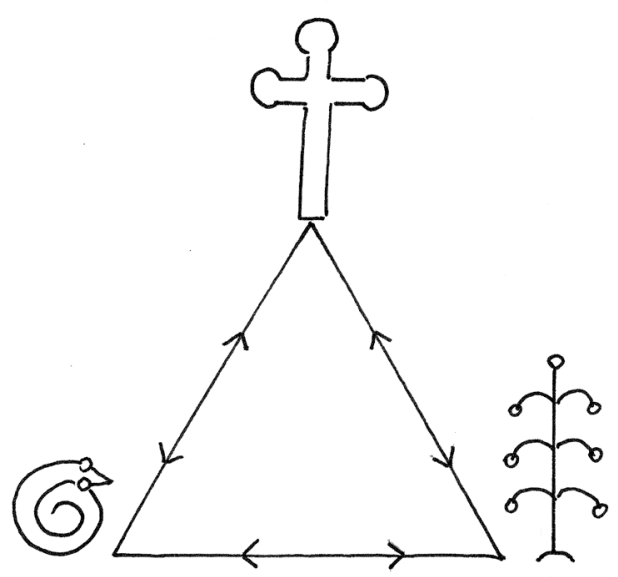

Fig. 11. I de kristne symbolers verden deler slangen, livets træ/Arbor Vitae og Kristi kors identitet. De kan optræde hver for sig, to eller alle tre sammen. Tegning: Lise Gjedss $\varnothing$ Bertelsen.

f.). I de kristne symbolers verden deler slangen, livets træ/Arbor Vitae og Kristi kors identitet (fig. 11). Motiverne kan optræde hver for sig, to eller alle tre sammen eller sammensat til ét motiv som for eksempel på livstræsringkorset på U 337 Granby, Orkesta sogn, Sverige, hvor korset står i blomst med på én gang akanthuspalmetter og slangehoveder (Bertelsen 2002, s. 29, fig. 20c). Den fælles identitet imellem det kristne livstræ og Kristi kors er en af de væsentligste pointer i den sene vikingetids kunst og den efterfølgende romanske kunst. En version af den gamle kristne legende om dette fællesskab er nedskrevet i "Legenda Aurea" (Den gyldne Fortælling) af Jacobus de Voragine i 1200-tallet (Bertelsen 2002, s. 17 f.).

Nøglen til forståelse af Taustaven fra Pingvellir er slangen og livstræets fælles identitet, der kommer tydeligt frem i Det Gamle Testamentes 2. Mosebog kapitel 7 vers 8-13 om Arons stav, hvori vi læser om Aron og Moses, der gør undere for Farao. Når Aron kaster sin stav ned for Farao, forvandles staven til en slange, og når han igen griber den i halen, bliver den atter til en stav, som senere blomstrer. Dette demonstrerer dobbeltnaturen i Arons stav, der snart springer ud med blade, snart som slanger. På ark 218 i Sankt Chads evangeliar/Lichfield evangeliaret fra o. 730 indledes Lukas evangeliet af en miniaturetegning af Sankt Lukas evange- 
listen, som i sin højre hånd holder en stav, der deler sig i to spiraler, hver med syv små trekløver, som repræsenterer den mirakuløse stav, som blomstrer (fig. 7b midtfor og 7c til højre) (Bertelsen 2002, s. 29; Gotfredsen og Frederiksen 2003, s. 103, fig. 69; Meehan 1999, s. 37, fig. 14). Over evangelisten ses hans traditionelle symbol oksen. ${ }^{3}$ Evangeliaret er udstillet i Lichfield katedrals kapitelhus, England.

Også på flere af de berømteste irske højkors, som vikingerne har været fortrolige med, møder vi Taustaven. På østsiden af det berømte 5,8 m høje Muiredach's højkors i Monasterboice, Co. Louth, Irland fra 800-tallets midte eller senere del $^{4}$ ser vi i ringkorsets centrum en gengivelse af dommedag, hvor Kristus står og holder en blomstrende Taustav, der deler sig i to spiraler (kroge) i sin højre hånd, og opstandelsens kors i sin venstre (Harbison 1992, Volume II, fig. 473). Korset er hugget i sandsten og er et af Irlands smukkeste højkors.

\section{Analyse af topstykket til Taustaven fra Pingvellirs billedstruktur}

Ved billedstruktur forstås de informationer, der kan aflæses af motivernes indbyrdes placering og gengivelsesmåde i et eller flere billedfelt/-er, fordi et motivs status på den tid var afhængig af sin placering $\mathrm{i}$ et eller flere billedfelt/-er samt sin gengivelsesmåde (fig. 12). Et motiv, som er anbragt centralt, $\varnothing$ verst og/eller i midtlinjen af billedfeltet, har fornem status, fordi midtaksecentrering er et ekko af kristendommens monoteistiske struktur (= dyrkelse af kun én gud). Et motiv, som er anbragt perifert, nederst og/eller til siden i et billedfelt, har lavere status. En face gengivelse af et motiv har høj status, fordi det signalerer autoritet og kommunikerer tilbage til betragteren. Lidt lavere status har den profilsete gengivelse og lavest gengivelse i fugleperspektiv. Et motiv gengivet i profil har så at sige fået sine sanser halveret, det lader sig se på, men kommunikerer ikke tilbage; derimod kan det ofte have en vigtig funktion som en retningsgiver, der peger et sted hen (Bertelsen 2002, s. 17).

\footnotetext{
${ }^{3}$ Da Sankt Chad blev biskop i 669 stiftede han et lærdomssæde i Lichfield i hjertet af kongedømmet Mercia.

${ }^{4}$ Korsets dateringer svinger som for eksempel til 800-tallets midte (Frederiksen 2001, s. 253, fig. 24) eller til 800-tallets sidste fjerdedel, muligvis mellem 880 og 890 (skriftlig information til mig den 15. september 2020 fra Peter Harbison).
} 


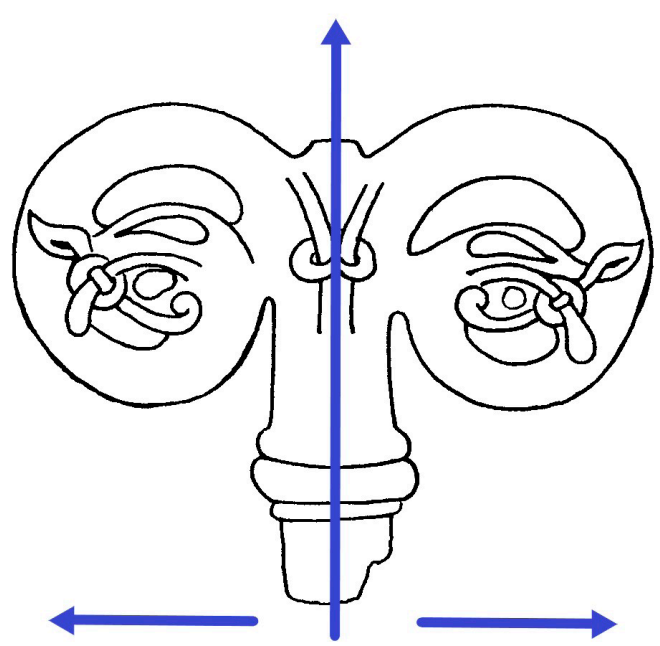

Fig. 12. Topstykket af den formodede bispestav fra Pingvellir, Island. Urnes stilgruppe Pr 3. Pjms 15776. I den fornemme midtakse er det en face sete sløjfemotiv placeret, og måske har der skullet være en mindre topfigur $\emptyset$ verst. Perifert ses krogene bestående af slanger set i profil. Tegning: Lise Gjedss $\varnothing$ Bertelsen.

\section{Konklusion}

Min artikel her er en videre bearbejdelse ud fra Kristján Eldjárns publiceringer af topstykket af den formodede bispestav fra Pingvellir, som udkom i 1971. Eldjárn vurderede topstykket til at være udført i Urnesstil, daterede det til Islands første katolske biskop Ísleifur Gissurarson på Skálholts embedsperiode, og anså det derfor som en mulighed, at der kunne være tale om denne biskops bispestav. ${ }^{5}$

Den sene vikingetids kunst er elegant nordisk design i stadig udvikling med overvejende europæisk kristent symbolindhold. Kunsten afspejler fantasi, pragt og selvbevidsthed, men til trods herfor var den underlagt bestemte regler, hvilket gør det muligt for os i dag at inddele materialet i stilistiske grupper. Stilene var en raffineret leg med linjer, der umiddelbart kan opleves og beundres af mennesker til alle tider. Men meddelelsen var i et elegant symbolsprog, der derimod ikke umiddelbart kan forstås

\footnotetext{
${ }^{5}$ Men Kristján Eldjárn pointerede, at der på samme tid i Island også havde været omrejsende udenlandske missionsbiskopper, som ikke var viet til nogen bispestol, så topstykket kan teoretisk set have tilhørt en af disse.
} 
af mennesker fra andre tider end samtiden. For at nærme os en forståelse af, hvad topstykket fra Pingvellir repræsenterer og udstråler, er det derfor vigtigt $\mathrm{i}$ analysen at kunne skelne imellem begreberne: stil, motiv og billedstruktur. Sen vikingetids kunst blev udført på mange forskellige materialer (metal, træ, sten, ben, tand, tak, rav, tekstiler mm.), i alle formater (fra monumental- til miniaturekunst) samt i to- såvel som tredimensionelle udgaver. Alt dette var det fysiske fundament for kunsten og grundlag for dens store udbredelse og gennemslagskraft.

Det stilistiske spiller en nøglerolle i dateringen af topstykket fra Pingvellir og, at det er udført i Urnesstil er ubestrideligt. Men Urnesstilen levede længe og var den dominerende mode i hele 1000-tallets anden halvdel og løbende ind i anden fjerdedel af 1100-tallet, så en mere detaljeret stilistisk analyse af topstykket var påkrævet. Gräslunds stilistiske typologi for billedrunestenenes ornamentik i Urnes stilgrupperne Pr 3, Pr 4 og Pr 5 var ikke etablerede eller dateret, da Eldjárn publicerede topstykket fra Pingvellir i 1971. Men i dag er det klart, at topstykket hører til i Urnes stilgruppe $\operatorname{Pr} 3$, der stort set falder sammen med tiden 1056-1080, der var biskop Ísleifur Gissurarsons embedsperiode.

Hvad angår motiverne, så er topstykkets kroge med de to profilsete slangehoveder umiddelbart bispestavens mest iøjnefaldende træk, og de udtrykker kraftfuldt motivets dualisme af godt og ondt. De to en face sete sløjfemotiver på døllen var i sin tid sandsynligvis pars pro toto for det kristne livets træ og deres lidenhed til trods har de høj status. Sløjfemotivet er den lås, som samler de to slanger til én slange i døllen; det kristne livstræ og slangen hører intimt sammen også med Kristi kors. Øverst må topstykket af bispestaven skulle have været lukket enten i form af en lille plade eller en mindre figur, eventuelt et kors. Hvis det har været tilfældet, ville et sådant kors have indtaget den fornemste plads på genstanden $\mathrm{i}$ følge det kristne billedes struktur. Topstykkets billedstruktur er klart underlagt den kristne billedstruktur, som er et ekko af kristendommens monoteistiske struktur (= dyrkelse af kun én gud).

Resultaterne af mine analyser af topstykket af den formodede bispestav fra Pingvellir underbygger Eldjárns vurdering af genstanden som udført i Urnesstil, men med understregning af, at der er tale om denne stils tidlige fase, såkaldt $\operatorname{Pr} 3$. Den er dateret til ca. 1045-1075, hvilket ikke forringer Eldjárns forslag om, at topstykket kan have tilhørt Islands første katolske biskop Ísleifur Gissurarson, der residerede på Skálholt i tiden 1056-1080, og dermed kan have været den mulige ejer af bispestaven. Sidstnævnte kan ikke bevises, men tanken er fristende. 


\section{Kilder og referencer}

Bertelsen, Lise Gjedss $\varnothing, 1992$ : Præsentation af Ålborg-gruppen - en gruppe dyrefibler uden dyreslyng. I: Aarbøger for Nordisk Oldkyndighed og Historie 1991. S. 237-264.

Bertelsen, Lise Gjedssø, 1994: Yngri Víkingaaldarstílar á Íslandi. I: Árbók Hins íslenzka fornleifafélags 1993. S. 51-73.

Bertelsen, Lise Gjedss $\varnothing$, 2002: Den sene vikingetids kunst. I: Vikingetidens Kunst. En udstilling om kunsten i vikingernes verden og efterverden ca. 8001250. Red.: Lise Gjedss $\varnothing$ Bertelsen. Jelling. S. 16-34; 61-71. ${ }^{6}$

Bertelsen, Lise Gjedss $\varnothing$, 2006: On Öpir's pictures. I: Runes and their secrets. Studies in runology. Red.: Marie Stoklund, Michael Lerche Nielsen, Bente Holmberg \& Gillian Fellows-Jensen. Copenhagen: Museum Tusculanum Press, University of Copenhagen. S. 31-64.

Bertelsen, Lise Gjedss $\varnothing, 2015$ : The Cross Motif on Late Viking Age Art Picture Runestones in Västergötland. I: Lund Archaeological Review 20 (2014). S. 55-78.

Bertelsen, Lise Gjedssø, 2020: Um tá-bagalinn frá Pingvöllum. Hirðisstafur Ísleifs Gissurarsonar Skálholtsbiskups? I: Minjaping helgað Mjöll Snæsdóttur á sjötugsafmæli hennar 12. febrúar 2020. Fornleifastofnun Íslands. Reykjavík. S. 203-218.

Bertelsen, Lise Gjedss $\varnothing$ og Mjöll Snæsdóttir, 2011: Reykjavik - fra vikingetids storgård til moderne hovedstad. I: Geografisk Orientering 41/4. (Tema: Ekskursioner i Island.). S. 198-206.

Eldjárn, Kristján, 1956: Kuml og haugfé úr heiðnum sið á Íslandi. Akureyri: Bókaútgáfan Norðri.

Eldjárn, Kristján, 1971a: Tá-bagall frá Pingvöllum. I: Árbók Hins íslenzka fornleifafélags 1970. S. 5-27.

Eldjárn, Kristján, 1971b: En tau-stav fra Island. I: KUML 1970 for P. V. Glob. Årbog for jysk arkæologisk selskab 1970. København. Red.: Poul Kjærum. S. $65-81 .^{7}$

Frederiksen, Hans Jørgen, 2001: Ægyptisk indflydelse på irsk og angelsaksisk kunst i 700- og 800-tallet. I: Arven fra Ægypten I. Beundring og frygt. Kristendom og visdom. Red.: Erik Christiansen. Billedred.: Bo Dahl Hermansen. (Tidsskriftet SFINX 2001). S. 243-257.

Fülöp, András-András Koppány, 2004: A crosier from the territory of the Veszprémvölgy convent. I: Acta Archaeologica Academiae Scientiarum Hungaricae 55 (2004). S. 115-135.

Gotfredsen, Lise og Hans Jørgen Frederiksen, 2003: Troens billeder. Romansk kunst i Danmark. København: Gads Forlag.

\footnotetext{
${ }^{6}$ Taustaven fra Pingvellir har heri katalognummer 33.

7 Årbogen var tilegnet P. V. Glob, daværende direktør for Danmarks Nationalmuseum og rigsantikvar, på hans 60-årsdag den 20. februar 1971.
} 
Gräslund, Anne-Sofie, 1992: Runstenar - om ornamentik och datering 2. I: Tor Tidskrift för arkeologi 24. S. 177-201.

Gräslund, Anne-Sofie, 2006: Dating the Swedish Viking-Age rune stones on stylistic grounds. I: Runes and their Secrets. Studies in runology. Red.: Marie Stoklund, Michael Lerche Nielsen, Bente Holmberg \& Gillian Fellows-Jensen. Copenhagen: Museum Tusculanum Press, University of Copenhagen 2006. S. 117-139.

Gröndal, Gylfi, 1991: Kristján Eldjárn. Ævisaga. Reykjavík: Forlagið.

Harbison, Peter, 1992: The High Crosses of Ireland. An Iconographical and Photographic Survey. Volume II: Photographic Survey. Römisch-Germanisches Zentralmuseum. Forschungsinstitut für Vor- und Frühgesvchichte in Verbindung mit Royal Irish Academy Dublin. Bonn.

Imer, Lisbeth M. og Roberto Fortuna, 2016: Danmarks runesten. En fortælling. [København:] Nationalmuseet, Gyldendal.

Karlsson, Lennart, 1981: Sløjfemotivet i Sverige under missionsskedet. I: Romanske stenarbejder 1. Red.: Jens Vellev. Højbjerg: Forlaget hikuin. S. 91-118.

Meehan, Aidan, 1999: Celtic Design. The Tree of Life. London: Thames and Hudson.

Vellev, Jens, 1981a: Kirkens kryb. I: Skalk 1981/4. S. 16-17.

Vellev, Jens, 1981b: Sløjfeportalerne omkring Randers. I: Romanske stenarbejder 1. Red.: Jens Vellev. Højbjerg: Forlaget hikuin. S. 9-68.

Wessén, Elias \& Sven B. F. Jansson, 1949-51: Upplands Runinskrifter. Granskade och tolkade av Elias Wessén och Sven B. F. Jansson. Tredje delen. Tredje häftet. Sveriges Runinskrifter utgivna av Kungl. Vitterhets Historie och Antikvitets Akademien. Åttonde Bandet. Stockholm.

\section{Webside}

Svenska kyrkan: Brågarps kyrka. <https://www.svenskakyrkan.se/ststaffan/ bragarpskyrka>.

\section{Summary}

On May 24, 1957, a bronze object was unearthed below a patch of grassy ground a short distance from the Pingvellir house, a farm situated at the ancient meeting place of the Icelandic parliament about 40 kilometers east of Reykjavik (fig. 1). The object was identified as a double-crook crosier/a Tau crosier, designed in the Urnes style, the youngest of Late Viking Age art's styles, and suggested as perhaps dated from the first Catholic bishop of Iceland Ísleifur Gissurarson's tenure 1056-1080. The results were published in 1971 both in Icelandic and Danish by 
Dr. Kristján Eldjárn, then director of Pjóðminjasafn Íslands/National Museum of Iceland and later President of Iceland. My article is a further elaboration of Kristján Eldjárn's publications and is written in Danish for Scripta Islandica and translated to Icelandic with some abbreviations for the book Minjaping - helgad Mjöll Snaesdóttur á sjötugsafmaeli hennar 12. febrúar 2020. The object is carried out professionally and cast in bronze in one piece with no trace of gilding. Today the metal is oxidized to a dark green. The Tau crosier consists of a socket with two symmetrically placed crooks and measures $8.6 \mathrm{~cm}$ across these. The top of the original staff of cornel wood is still preserved inside the socket with a pine wedge at the top (fig. 2). When looking at the object from above, one notes that there is an uneven hole through the bronze down to the top of the wood staff (fig. 3). This hole must originally have been closed with a plate or a tiny plastic figure perhaps in the shape of a cross as know from head of the Macedonian Orthodox Church, archbishop Stephen's Tau crosier (fig. 4).

The stylistic affiliation plays a key role in dating the Pingvellir crosier, which is undeniable executed in the Urnes style. However, this style lived long and was the dominant fashion throughout the second half of the 11th century and continued into the second quarter of the 12th century in the world of the Vikings. A more accurate subdivision of this style into groups was long required and not available in 1971. In the 1990s however, Professor Anne-Sofie Gräslund, Uppsala University established a now widely recognized stylistic typology and dating for zoomorphic runestones of especially Uppland with runic animals' heads seen in profile; her groups named: $\operatorname{Pr} 3, \operatorname{Pr} 4$ and $\operatorname{Pr} 5$ (Pr stands for profile) match early, classic and late Urnes style, approximately dated to about 1045-1075, 1070-1100 and 1100-1130. The stylistic typology and dating also apply to contemporary embellishments on different materials and scales as for instance concerning the Pingvellir crosier (fig. 5a), brooches of the Ålborg group (fig. 5b) and the Tau crosier from Veszprémvölgy, Hungary (fig. 6a, b, c, d); all representatives of Gräslund's group $\operatorname{Pr} 3$.

The motifs of the Pingvellir crosier include a loop shaped like a pretzel with lines running through it on both faces of the socket and two serpent heads and necks building the hooks. Whether for example, a tiny cross might have closed the hole at the top of the crosier is unknown. The loop motif is like a lock, which unites the two serpents (fig. 7a). The motif can in no way be dismissed as an ornament without meaning. Like acanthus leaves and palmettes it often acts as pars pro toto (Latin for a part (taken) for a whole) and symbol of the Christian tree of life in Late Viking Age and Romanesque art. When reading the Old Testament, Exodus 7, 8-13 (Aron's rod) about Aron and Moses working miracles before Pharaoh one comes to mind the intimate connection between the serpent and the tree of life. When Aron cast down his rod before Pharaoh, the rod became a serpent. When Aron grabbed it by its tail, it turned back again into a rod, which later flourished. This shows the double nature of Aron's rod, which burst into serpents or leaves (figs. 7b-7c) at the right times. The profound connection in Christianity between the serpent and the tree of life also often includes the cross 
of Christ, documented numerous times on for instance picture runestones (figs. $8 \mathrm{a}-8 \mathrm{~b}$ ). The Pingvellir serpents' heads terminate in a long pointed and twisted lip lappet held together with the animal's lower jaw by a ring. The drop shaped eye points forward and fills a great deal of the space of the head. A head lappet is slightly indicated. The Pingvellir crosier is executed in the Urnes style Pr 3 and thereby approximately dated to about $1045-1075$. The serpent is an ambivalent motif, also in Christianity, powerfully expressing the dualism of strong powers of good and evil. After appearing frequently in Late Viking Age art the combination of the loop motif keeping together serpent heads and necks continues in the Romanesque art on for example the stave church portal from Hopperstad in Norway and several stone portal overlays, called loop portals, on parish churches in the vicinity of Randers in Denmark (fig. 9a). From a modern color experiment, it is clear how the loop motif there holds two one hook crosiers together above a church entrance door (fig. 9b). On the portal bar/plank from Brågarp Church, southwest Scania two serpents' heads and necks of Urnes group Pr 4 are joined by the long head lappet of the heraldic right serpent arranged horizontally in an octagonal loop around their necks (fig. 10). The object belongs to the Historical Museum at Lund University inventory number 28733a.

In the world of Christian symbols, three of the most important motifs - the serpent, the Arbor Vitae/tree of life and the cross of Christ - share identity. They can all occur alone, but very often two or all three of them appear together (fig. $11)$.

The pictorial structure of the Pingvellir crosier is the Christian pictorial structure, which elucidates the message of the artwork by placing the motifs in a specific relation to each other and by using deliberately different ways of rendering the motifs. That is because the status of a motif at that time depended on its location in one or more picture field/-s and its way of reproduction (fig. 12). Motifs placed on top, centrally and/or in the center axis of the picture field have a high status, because the pictorial structure is constructed on the principles of the hierarchic center axis, which echoes Christianity's monotheistic structure (= worship of only one god). Motifs placed peripherally or at the bottom are of secondary importance in the picture-field. Motifs rendered en face are of a higher status in the picture field than motifs rendered in profile, because the former communicate with and address themselves directly to the spectator whereas the latter is only being looked upon and do not look back. The en face seen loops, pars pro toto of the tree of life at the center axis on both faces of the socket, have high status. The serpents' heads and necks arranged peripherally and seen in profile are of a lower status. If a tiny cross eventually has closed the hole on top of the crosier between the serpents' necks it would have been of the highest status.

The results of my analyzes of the Pingvellir crosier are that its stylistic affiliation belongs to the early phase of the Urnes style, Gräslund's Pr. 3 group dating approximately to $1045-1075$, a span of time largely concurrent with bishop Ísleifur's tenure 1052-1080. Elegant Nordic design was combined with clear Christian 
symbols arranged according to the Christian pictorial structure and thereby able to communicate highly abstract theological relations between the serpent and the tree of life and maybe the cross of Christ. That this content was understood in the world of Vikings is clear from the fact that this relationship was conveyed consistently throughout Late Viking Age art and into the Romanesque art.

Keywords: bishop's crosier, Tau crosier, Urnes style, loop motif, serpent symbolism, cross of Christ, bishop, bishop's seat, Ísleifur Gissurarson, Skálholt, Pingvellir.

Lise Gjedss $\phi$ Bertelsen

Arkaeolog, mag.art., ph.d.

Marie Curie Research Fellow 2012-2014

Inst. för arkeologi och antik historia, Uppsala universitet

ORCID iD 0000-0002-5719-5481 



\title{
An Icelandic Noctuary of 1794
}

\author{
MÁR JÓNSSON
}

\section{Introduction}

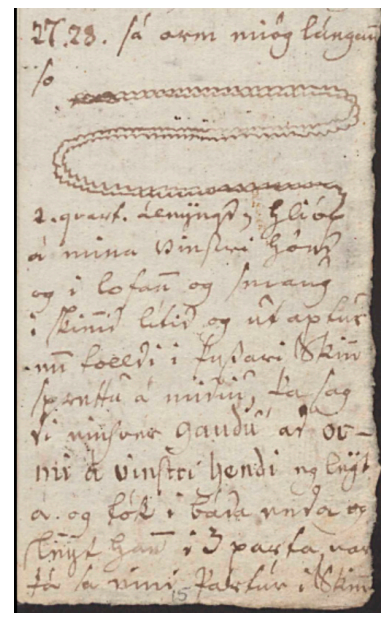

27. 28. Sá orm mjög langan so [drawing] 2 kvartel á lengd, hljóp á mína vinstri hönd og í lófann og smaug í skinnið lítið og út aftur en tolldi í pessari skinnsprettu á miðju. Pá sagði einhver ,gáđu að ormi á vinstri hendi“", eg leit á og tók í báđa enda og sleit hann í prjá parta, var pá sá eini partur î skinninu og tók eg hann líka burt og kastaði niður og hvorfu allir partarnir burt, en kenndi ei til minnsta og greri strax.

Image 1 .

On the night to 27 February 1794, the Rev. Sæmundur Hólm at Helgafell on Snæfellsnes dreamt that a worm, some $25 \mathrm{~cm}$ long, appeared on his left hand. It crawled onto his palm, then into and out of the skin, before staying put in the rift. Sæmundur examined the worm, before seizing both ends and tearing it into three pieces; one of these did not move and so he threw it away. All three pieces immediately disappeared. He felt no pain and the wound healed at once. Sæmundur duly wrote a brief note about 
this and included a drawing of the worm. ${ }^{1}$ At this time, he had lived at Helgafell for just over four years, was 45 years old and unmarried. He is now known for his portraits of prominent Icelanders as well as for several colourful pictures of volcanoes and phantasmagoric landscapes. His poetry, not all of which has yet been published, is considered to be somewhat awkward and uninspired. The diary of his dreams, or "noctuary" (to use the eighteenth-century English term), marks him out as the author of the only extant accounts of ordinary dreams in post-medieval Icelandic literary history. Indeed, few such texts exist anywhere in the world from this period.

Sæmundur seems to have made notes on his dreams over many decades, though only some of these accounts survive. The most substantial cluster can be found in an autograph notebook, beginning in a middle of a dream from late January 1794 and ending with one from the last day of the same year. The worm-dream noted above is one of many included in this booklet, along with poems, accounts and any current news that Sæmundur judged to be of interest. Several more dreams from the beginning of 1795 and others from 1807 and 1819-1820 are preserved in a mid-nineteenth century copy of the original text. The present article examines the oldest dreams with the aim of demonstrating their close and vivid association with Sæmundur's worldly concerns at that time and his overall life experiences until then, with emphasis on the years 1789-1795.

\section{A biographical sketch}

On 13 July 1789, Sæmundur Hólm arrived in Reykjavík, after three weeks at sea, returning to his home country after fifteen years abroad. The ship had left Copenhagen on 20 June and the passage had been a rough one. Sæmundur had been promised an appointment as priest at Helgafell, one of the richest parishes in the country. A farmer's son, born in 1749 at Hólmasel in Meðalland in Southeast Iceland, he had shown great promise as a boy, and was sent to the cathedral school at Skálholt in 1766. He graduated five years later and, according to rector Bjarni Jónsson (17251798), on 3 June 1771, he was a polite and well-disposed young man,

${ }^{1}$ Draumadagbók Samundar Hólm, 100. I wish to thank Andrew Wawn for reading the article closely, correcting language and style. 
always respectful to his superiors, and an eager and gifted student: "siðprúður og vel innrættur unglingur, er ávallt hefur gefið gaum orðum yfirboðara sinna. Námfús er hann í góðu lagi og vel hæfur til bóknáms.” His greatest talent, however, lay in drawing ("dráttlist"); with proper instruction, Bjarni believed, Sæmundur could become a second Apelles, the famous fourth-century BC Greek painter. He stayed first with his parents at Staðarholt, before being appointed (on 18 May 1772) deacon at Kirkjubæjarklaustur, some $40 \mathrm{~km}$ away. ${ }^{2} \mathrm{He}$ had also been considered for a position as assistant to Eyjólfur Jónsson (1735-1775), a newly appointed Royal astronomer. On that occasion, Bishop Finnur Jónsson had written in support of the young man: he was exceptionally talented in carpentry and drawing ("til allra smíða, til að teikna eður draga upp"), indeed, in anything related to the imagination and to working with his hands ("annað pvílíkt sem kemur uppá imaginationen og handatiltektir"). Not only could he imitate whatever he saw, but he was also better than any other student at imagining something and then finding a way to make it: "ei einasta í pví að gjöra eftir pví sem hann sér, heldur og til að uppfinna sjálfur modell til hlutarins og aðferðina að gjöra hann, er hann so skjaldfengið subjectum að eg pekki nú ei hans líka af peim studiosis sem eg hefi viðkynnst." Though nothing came of that potential opportunity, the bishop and others encouraged Sæmundur to pursue his studies in Copenhagen. Accordingly, on 2 August 1773, the bishop informed the Royal governor at Bessastaðir that Sæmundur was about to leave for Copenhagen to study fine arts and related subjects: "for at lade sig informere i graphicen og der til hörende videnskaber." ${ }^{4}$

For some reason, however, the trip was postponed for a year, and it was not until 25 August 1774 that Sæmundur set sail from Eyrarbakki on board a merchant ship, arriving in Copenhagen on 4 October. He completed the university's entrance examination (examen artium) on 22 December, and then the first part of the general studies curriculum (examen philosophicum) in the Spring of $1776 .{ }^{5}$ On 10 April, he applied,

\footnotetext{
${ }^{2}$ Matthías Pórðarson, Íslenzkir listamenn I, 12; National Archives of Iceland (NAI). Rtk. B11/5. Letter journal 7, sheet 32: 29 December 1786, attestation nr. 1. On Apelles, see The Oxford Classical Dictionary, 118-119. The first half of this article is based on my introduction to Draumadagbók Samundar Hólm, 11-59, but references to most of the secondary sources are given here, as well as to the principal unpublished sources.

${ }^{3}$ NAI. Bps. A-IV, 18. Copybook of Skálholt 1770-1773, 639; Matthías Pórðarson, Íslenzkir listamenn I, 13.

${ }^{4}$ NAI. Bps. A-IV, 18. Copybook of Skálholt 1770-1773, 880-881.

${ }^{5}$ Hannes Porsteinsson, Guðfrað̇ingatal, 273; Bjarni Jónsson, Íslenzkir Hafnarstúdentar, 122.
} 
as Sæmund Magnusen Holm, for a grant in order to study mathematics and drawing at the Royal Academy of Arts (Det Kongelige Kunstakademi), founded in 1754. He forwarded with his application six drawings of Icelandic volcanoes and a map of the southern part of the country. On 10 July 1776, the application was approved, and Sæmundur was awarded an annual stipend of 50 rixdaler for three years. ${ }^{6}$ He thus became the first Icelander to attend the Academy. He was a diligent student, and in just three semesters had advanced to the fourth class. On 27 September 1779, two of his professors, Johannes Wiedewelt (1731-1802) and Cornelius Høyer (1741-1804), attested that Sæmundur had received his first silver medal and that, with further hard work, he would come close to achieving perfection: "opnaae megen Fuldkommenhed." That autumn, Sæmundur published a leaflet in which he described a tornado witnessed in Copenhagen, albeit that the accompanying drawings are not his own. In 1781 and 1782, his essay on lymegrass (melgresi) was printed in the learned journal Rit Lardómslistafélagsins, again with drawings by someone else. ${ }^{8}$ However, several of his own drawings did appear in Oeconomisk Reise igiennem de nordvestlige, nordlige, og nordostlige Kanter af Island (Copenhagen, 1780), a travel book by Ólafur Olavius (17411788). Indeed, Ólafur had wanted to include an essay by Sæmundur on glaciers and volcanoes, with numerous drawings, but the proposal was rejected by the Danish government on the grounds that Sæmundur had not undertaken this study at its behest, and also because the illustrations did not accord with the rules of artistic decorum: "Konstens Regler".

Sæmundur's parents did not have the means to support him and he survived on state grants and other occasional work, such as copying old manuscripts and drawing runes for the wealthy book-collector Peter Frederik Suhm (1728-1798), or producing pictures of distorted Icelandic landscapes and imagined medieval artefacts for the even wealthier Count

\footnotetext{
${ }^{6}$ PÍ. Rtk. B7/2. Bréfadagbók 3, sheet 6: 10 Apríl 1776; B7/3. Bréfadagbók 3, sheet 13: 10 July 1776.

${ }^{7}$ PÍ. Rtk. B11/5. Letter journal 7, sheet 32: 29 December 1786, attests nr. 7, 8; Matthías Pórðarson, Íslenzkir listamenn I, 15n. On these men and other Danes mentioned here, see C.F. Bricka, Dansk biografisk lexikon.

${ }^{8}$ Matthías Pórðarson, Íslenzkir listamenn I, 15; Porvaldur Thoroddsen, Landfraeðissaga Íslands III, 93-94.

${ }^{9}$ Ólafur Olavius, Ferðabók II, 54, 61, 193, 201, 215, 217, 228, 231, 236, 258; Lovsamling for Island IV, 450; Katalog over de oldnorsk-islandske håndskrifter, 106-109; Haraldur Sigurðsson, "Sæmundur Magnússon Hólm og kortagerð hans", 140, 142-143; Web. Vilhjálmur Örn Vilhjálmsson, "Eldgosamyndir Sæmundar Hólm".
} 
Otto Thott (1703-1785)..$^{10} \mathrm{He}$ would have liked to remain in Copenhagen, but he was strapped for cash, as he explained in a letter to Bishop Hannes Finnsson on 29 May 1779, and he also worried that he would never again see his ageing parents: "Pau eru gömul farin að verða, guð veit hvort eg fæ meir pau að sjá." ${ }^{11}$ With the prospect of pursuing his future in Iceland, he undertook further studies in theology, completing his examinations on 16 January 1783. At this time, it was the Danish king who decided on clerical appointments to the best parishes in Iceland, and one of these had become available, Oddi á Rangárvöllum, just $150 \mathrm{~km}$ to the west of Staðarholt. Sæmundur duly applied for the position. That same spring, he was awarded a gold medal at the Academy of Arts for having produced a new kind of varnish paper ("Fernis-Papir"), an invention lavishly praised by Johan Martin Preisler (1715-1794), professor and Royal engraver. ${ }^{12}$ All in all, life was good for Sæmundur, as he explained in a letter to Bishop Hannes on 11 June $1783 .{ }^{13}$

Three days earlier, on 8 June 1783, the volcanic eruption now known as Skaftáreldar had begun, with earthquakes, acid rain, lava flows and clouds of ash. Two weeks later, the newly built church at Hólmasel (and other buildings) were burnt to the ground. Several farms in the parish were destroyed by lava, sand and floods. ${ }^{14}$ Staðarholt, the farm where his parents lived and Sæmundur grew up, remained mostly intact but his mother, Guðleif Sæmundsdóttir (b. 1709), died and was buried on 3 August that year. ${ }^{15}$ News of the eruption reached Copenhagen via merchant ships arriving from Iceland on 4 and 5 September. ${ }^{16}$ On that second day, the front page of Kiфbenhavns Adresse-Contoirs Efterretninger featured excerpts

\footnotetext{
${ }^{10}$ Katalog over de oldnorsk-islandske håndskrifter, 115, 408; Web. Vilhjálmur Örn Vilhjálmsson, "Furðumyndir frá 18. öld á Listasafni Íslands: Fyrri hluti" and "Furðumyndir frá 18. öld á Listasafni Íslands: Síðari hluti”.

${ }^{11}$ Lbs. Lbs 27b fol. Bréfasafn Hannesar Finnssonar: Sæmundur Hólm 29. maí 1779; Matthías Pórðarson, Íslenzkir listamenn I, 15n-16n.

${ }^{12}$ NAD. Royal Academy. Akademiforsamlingen. Journalsager 1.2-3. Indkomne breve 1779-1788.

${ }^{13}$ Lbs. Lbs 28 fol. Bréfasafn Hannesar Finnssonar: Sæmundur Hólm 11. júní 1783.

${ }^{14}$ Sigurður Pórarinsson, "Annáll Skaftárelda", 11-22; Porleifur Einarsson and Edda Lilja Sveinsdóttir, "Nýtt kort af Skaftáreldahrauni og Lakagígum", 38, 42; "Heimildir til sögu Skaftárelda og Móðuharðinda", 296.

${ }^{15}$ Sæmundur Hólm, Om Jordbranden paa Island, 68; Már Jónsson, "Sorgarviðbrögð Sæmundar Hólm vegna Skaftárelda”, 173.

${ }^{16}$ Kiфbenhavnske Tidender 8 September 1783, 3. Danish newspapers from these years are available at Web. Det Kgl. Biblioteks mediesamlinger, http://www2.statsbiblioteket. $\mathrm{dk} /$ mediestream/avis/
} 
of a detailed account from the merchant J.C. Sünckenberg (1757-1806), with a longer version appearing five days later in a different newspaper. On 25 October, the government decided that collections for needy Icelanders would be taken up in churches in Copenhagen on the first two Sundays in the new year. The Icelander Jón Eiríksson (1728-1787), an influential official, prepared a detailed description of the catastrophe in Danish, which was read aloud in churches on 4 January $1784 . .^{17}$

As for Sæmundur, despite being refused access to official reports, he drew on all available information while writing Om Jordbranden paa Island $i$ Aaret 1783, an 80-page booklet that included two maps of VesturSkaftafellsýsla. One of these was based on a map prepared by Sæmundur in 1771, while the other showed the extent of the destruction, as described in his sources. The preface is dated 25 February 1784, and the book was available in bookshops as early as 4 May. ${ }^{18} \mathrm{~A}$ month later, the curacy at Oddi was awarded to someone else. On June 25, Sæmundur wrote to the Chancery asking for a promise on any of the other parishes to which the king would make appointments, arguing that he had spent ten years in Copenhagen and earned high praise on completion of his studies. He added that he was a native of the area hardest hit by the recent eruption, and that his father's property had been all but destroyed. The Chancery recognised the force of Sæmundur's case and on 17 July it asked the resident Governor of Iceland, Lauritz Thodal (1718-1808), to find a parish for Sæmundur. ${ }^{19}$

Sæmundur's sister Valgerður (b. 1744) and brother Porvaldur (b. 1767) died of hardships resulting from the eruption. Their father, Magnús Guðmundsson (1714-1788), survived, however, and, despite the prohibitive costs involved, Sæmundur travelled to Iceland in the summer of 1786 to visit him. He sought to defray some of the expenditure by applying for a Royal grant on the grounds that during his stay he could undertake research relating to the eruption, but his application was unsuccessful. He sailed from Copenhagen on 4 July and arrived in Reykjavík on 9 August. He remained at Staðarholt from 23 August to 5 September, before travelling to the port of Berufjörður in the East. He was back in

\footnotetext{
${ }^{17}$ Lovsamling for Island IV, 763-764; Gísli Ágúst Gunnlaugsson, "Viðbrögð stjórnvalda í Kaupmannahöfn við Skaftáreldum”, 192-193.

${ }^{18}$ Sæmundur Hólm, Om Jordbranden paa Island, 40, 41; Kiøbenhavns Adresse-Contoirs Efterretninger 4. mai 1784, 7.

${ }^{19}$ PÍ. KA/32. Innkomin bréf og önnur skjöl 1784, sheet 22: 25 March 1784; sheet 35: 25 June 1784.
} 
Copenhagen by 11 November. On 22 March 1788, the Rev. Sigurður Stefánsson (1744-1798) of Helgafell was appointed bishop at Hólar in Hjaltadalur. Ten days later, on 1 April, Sæmundur applied for the vacant Helgafell parish, with letters of recommendation from former teachers. The Chancery decided to support him, and both Governor Hans Levetzow (1754-1829) and Bishop Hannes Finnsson agreed. On 14 March 1789, the Chancery informed Sæmundur that he could be reasonably certain that his wish would be granted: "giöre sig grundet haab om Deres önskes opfyldelse." ${ }^{20}$ On 11 June he received a loan for 200 rd., to be repaid out of the inheritance from his father. Five days later, he requested free passage to Iceland on a vessel whose departure was imminent, so that he could find falcons for the king, as the earlier loan he had received had barely covered essential expenses. He also noted that while in Iceland he would also need to undertake a lengthy trip in order to secure his inheritance. ${ }^{21}$

\section{Arrival}

On 14 July 1789, the day after his arrival, he met with Governor Levetzow at Bessastaðir, who had still not received confirmation from Bishop Hannes of Sæmundur's move to Helgafell. Sæmundur then travelled to the national assembly at Pingvellir, and from there to Skálholt. There, on 20 July, Hannes wrote to Levetzow, who in turn authorised the appointment four days later. ${ }^{22}$ At that moment, Sæmundur was on his way to Vík í Mýrdal, where, on 4 August, he duly received his inheritance. His father had died on 30 September 1788 and an inventory was made at Staðarholt on 8 June 1789. The property was valued at $138 \mathrm{rd} .54$ sk.; after all debts and costs had been paid, the modest sum of 116 rd. 90 sk. remained. By law, sons inherited twice as much as daughters, which meant that Sæmundur received 77 rd. 92 sk. while the four children of his sister Valgerður

${ }^{20}$ PĹ. KA/40. Innkomin bréf og önnur skjöl 1788, sheet 20: 22 March 1788; KA/42. Innkomin bréf og önnur skjöl 1789, sheet 18: 14 February 1789; Bps. A-IV, 40. Kansellíbréf til Skálholtsbiskups 1742-1801: 1 April 1788.

${ }^{21}$ PÍ. Rtk. B12/5. Bréfadagbók 8, sheet 60: 16 June 1789; Hannes Porsteinsson, AEfir larðra manna 58. Sæmundur Magnússon Hólm, 11.

${ }_{22}$ PÍ. Bps. A-IV, 28. Bréfabók Skálholts 1789-1790, 217; Stift. I-24. Bréfabók 1789-1791, 169. 
received $38 \mathrm{rd} .94$ sk. between them..$^{23}$ According to Sæmundur himself, in a diary fragment, his share amounted to $35 \mathrm{rd} .32 \mathrm{sk}$. and two horses. Returning to Skálholt, he was ordained on 7 September 1789. Then, after a further tortuous journey in bad weather, he finally arrived at Helgafell on 4 November.

Sæmundur seems to have suffered some sort of a nervous breakdown on his arrival there, and a letter to Bishop Hannes on 2 January 1790 finds him complaining bitterly. The houses were cold, and the winter weather had been severe; only a few days earlier, the sea had frozen over and it had been possible to walk on the ice. Hallgrímur Backmann (1739-1811), the district doctor, acting in his role as representative of Bishop Sigurður, proposed that the church and buildings at Helgafell should be assessed as soon as possible, but Sæmundur refused to agree because of the weather conditions. He prevailed and the assessment did not take place until 1 June 1790. Hallgrímur was in attendance at Setberg í Eyrarsveit, as was the Rev. Björn Porgrímsson (1750-1832), the provost, who had been a fellow student with Sæmundur during the winter of $1766-1767 .{ }^{24}$ The last assessment took place on 16 July 1781, and just two months later, on the night to 25 September, most of the buildings had been destroyed by fire. The Rev. Sigurður had subsequently received a royal grant of $120 \mathrm{rd}$. for their reconstruction and they were now worth $232 \mathrm{rd}$. The amount of the grant would be subtracted, as would a further sum of 33 rd. $60 \mathrm{sk}$. for essential repairs to cattle sheds and other small buildings, which meant that Sæmundur would have to pay $78 \mathrm{rd}$. 90 sk. He agreed to this in principle but indicated that payment would have to wait. A further financial issue was that the Rev. Guðmundur Eiríksson (1759-1805) was owed money for having taken care of the parish and church after Sigurður's departure. ${ }^{25}$ Accordingly, on 24 July 1790, Sæmundur paid 41 rd. 59 sk. to cover this cost. Thus, for all that he had been appointed to one of the best parishes in Iceland, Sæmundur was heavily in debt. The annual income from the parish was $81 \mathrm{rd}$. 61 sk., whereas the annual income of Björn Porgrímsson, provost at Setberg, was 46 rd.

Sæmundur viewed the situation with considerable displeasure, and in the years that followed complained loudly and frequently to the relevant authorities. In a letter to the Chancery, dated 6 October 1790, he challenged

\footnotetext{
${ }^{23}$ PÍ. Sýs1. Skaft. ED2/1. Dánarbú 1760-1809, 322r-328v.

${ }^{24}$ Íslenzkar aviskrár I, 254.

${ }^{25}$ Íslenzkar aviskrár II, 140-141.
} 
the current assessment and demanded a new one. After advice from the Rev. Björn, both bishops, and the governor, the Chancery rejected Sæmundur's demand on 14 April $1792 .{ }^{26} \mathrm{~A}$ year later, he reopened the case, addressing letters to Bishop Hannes and Governor Levetzow. On 3 May 1793, he forwarded to them a report on the situation at Helgafell on his arrival, and a month later he wrote again, addressing in great detail all aspects of his case. ${ }^{27}$ In late August 1794, Bishop Hannes visited the region and Sæmundur promised not to mention the assessment again. However, just a few days later, on 1 September, he broke his promise, insisting that a new assessment should be made. The bishop replied on 24 October, indicating that the decision had been made and would stand..$^{28}$ In his yearly report to the Chancery, he noted that Sæmundur was a genius in mechanical matters - "til mechaniske kunster især oplagt genie" - and had been a medal winner whilst at the Academy of Arts. The bishop concluded that Sæmundur should rather have pursued those interests: "at manden havde blevet paa den löbebane." ${ }^{29}$

Sæmundur now turned his attention to the Rev. Björn. On 1 November, he sent him seven written questions on his alleged mishandling of various issues. He subsequently made it clear that he rejected Björn's explanations and requested a fuller response. On 9 January 1795, Björn replied for a second time, indicating that he would only provide further answers in court. A month later, Sæmundur, much offended, wrote to the bishop and governor requesting permission to sue his superior. On 24 July, Bishop Hannes reluctantly agreed, but asked him to consider the matter carefully before proceeding. ${ }^{30}$ Sæmundur would not be deflected, however, and took Björn to court, just as, a few years later, he would take legal action against Hallgrímur for various alleged insults. Though both cases came to nothing, Sæmundur continued to involve himself in other quarrels, and spent much of his life either making accusations or defending himself against the accusations of others. He served as priest at Helgafell until 23 March 1819 and died in Stykkishólmur on 5 April 1821.

\footnotetext{
${ }^{26}$ PÍ. Bps. A-IV, 40. Kansellíbréf til Skálholtsbiskups 1742-1801: 14 April 1792 and 20 April 1793; KA/48. Innkomin bréf og önnur skjöl 1792, sheet 22: 14 April 1792; cf. sheet 39: 31 July 1792.

${ }^{27}$ PÍ. KA/57. Innkomin bréf og önnur skjöl 1798, sheet 1: 26 July 1798, nr. 5.

${ }^{28}$ PÍ. Bps. A-IV, 30. Bréfabók Skálholts 1793-1795, 604.

29 “Úr ferðabók Steingríms Jónssonar á vísitasíum með Hannesi Finnssyni”, 96; PÍ. Bps. A-IV, 30. Bréfabók Skálholts 1793-1795, 619.

${ }^{30}$ PÍ. Bps. A-IV, 31. Bréfabók Skálholts 1795-1798, 74.
} 


\section{The notebook}

An inventory of Sæmundur's belongings was made on 11 April 1821. He had left two chests full of manuscripts and papers that the provost had no time to examine, but Sæmundur's good friend, the district doctor Oddur Hjaltalín (1783-1840), took over the task. In his report on 21 September, he explained that most of the papers were in poor condition and in disarray: "velflestir illa meðhöndlaðir, sumpart fúnir, sumpart ruglaðir og illa brúkanlegir." He had managed to classify them, however, and found that there were drawings and maps, court documents and church records, official and private correspondence, sermons and 31 fragments of various political diaries: "31 stykki ýmislegra pólitískra dagbóka." ${ }^{11}$ The meaning of "political" here is unclear. Some of these items may have been brief essays on the dismal state of Icelandic society, but Oddur may well also be referring to actual diaries, including the noctuaries. These papers were sold on 12 September 1822 for 14 rd. 48 sk., but the details of the auction have not survived and the purchasers are unknown. ${ }^{32}$

The account of Sæmundur's 1794 dreams is preserved as a sizeable booklet written in his own hand, which can now be found at the bottom of a specially designed box (JS 318 8vo, item VII, in an extensive autograph collection of poetry; the first half of the booklet is in JS $3178 \mathrm{vo}$ ). To create these booklets, Sæmundur took folio-sized sheets and folded them in two to produce an oblong format (218 by $91 \mathrm{~mm}$ ). Some parts of this collection, or perhaps all of it, came into the possession of the poet Bjarni Thorarensen (1786-1841), who had known Sæmundur in his final years and composed an elegy after his death. Bjarni gave the manuscript to his son Vigfús (1821-1861), who in turn handed it to his brother Bogi (1822-1867). Bogi went to Copenhagen in 1846 to study law, and while there he presented it to the scholar and politician Jón Sigurðsson (18111879), who was an avid collector of manuscripts. Jón provided covers for the various parts of the collection, noting on the one for the noctuary that it was a journal, an annal and a book of dreams in Sæmundur's hand: "Dagbók, annáll og draumabók. (Frumrit eptir Sæmund Holm) 1794."33 Though Sæmundur's noctuary has been known to Icelandic scholars its

${ }^{31}$ PÍ. Sýsl. Snæf. ED2/3. Probate inventories 1811-1833, sheet 3: nr. 3 and 4.

${ }^{32}$ PÍ. Sýsl. Snæf. ED1/2, 1. Skiptabók 1822-1834, 36; cf. Snæf. EC1/1, 2. Uppboðsbók $1819-1834,39 \mathrm{v}-41 \mathrm{v}$.

${ }^{33}$ Lbs. JS 318 8vo. Kvæðasafn Sæmundar Hólm, 206r. The noctuary is at ff. 206r-305v, according to images at Web. https://handrit.is/en/manuscript/imaging/is/JS08- 
contents have attracted little interest. In a book published 1900-1902, Porvaldur Thoroddsen notes that the manuscript contains many poems and a book of dreams: "allmikil syrpa af kvæðum eftir Sæmund og draumabók". ${ }^{34}$ Two decades later, when Matthías Pórðarson published a selection of Sæmundur's verse, he barely mentions the "drauma- og minnisbók". Again, Hannes Porsteinsson, in an extensive collection of documents and information relating to Sæmundur, refers to a "dagbók, annál og draumabók" but failed even to examine the factual material it contains. ${ }^{35}$

Dreams tend to be immediately forgotten. To survive, they need to be written down. A fervent admirer of dreams, the English poet Samuel Taylor Coleridge (1772-1834), at the age of thirty, began to produce written descriptions of his dreams, most often, as Jennifer Ford has noted, immediately after waking up: "What Coleridge records in his notebooks is often written immediately after waking from a dream." He recorded as much detail as he could: "His notebook writings, often set down in haste and confusion, attempt to be an accurate record of the dream experience." ${ }^{36}$ Sæmundur probably worked in much the same way, preparing notes when he woke up, perhaps on loose slips of paper, though the noctuary entries are not always in chronological order and a copy must have been made soon afterwards. The notebook also contains a somewhat confusing jumble of other texts, such as drafts of poetry, records of births and deaths in the parish, local news and shopping lists, all written in 1794 and 1795. The pages have been numbered in pencil at some later date. Pages 1-37 and 56-62 belong together in a quire, whereas pp. 39-54 have been inserted, and pp. 46-53 are blank. Subsequent quires are pp. 63-78, 79-120, 121-134, 135-166 and 167-198. The dream narratives total 14,400 words, with the longest almost 400 words, while the great majority are much shorter.

Numerous dreams are illustrated with small drawings or signs. The drawings are easy to understand, with depictions of worms and faces, the moon and the sun, whereas the signs are harder to interpret: triangles, small clouds, circles dots and more (see here on p. 141-142). Most

0318\#page/206r++(431+of+636)/mode/1up and https://handrit.is/en/manuscript/imaging/ is/JS08-0318\#page/305v++(634+of+636)/mode/1up

${ }^{34}$ Porvaldur Thoroddsen, Landfraeðissaga III, 98.

${ }^{35}$ Matthías Pórðarson, Íslenzkir listamenn I, 35-37; PÍ. Hannes Porsteinsson, AEfir lardra manna 58. Sæmundur Magnússon Hólm, 3.

${ }^{36}$ Ford, Coleridge on dreaming, 56, 67. 
of these appear in the account of Sæmundur dreaming that he was back in Copenhagen. However hard to decipher, these images were certainly significant for him, as were the moons and circles in the diaries of the English writer Mary Shelley (1797-1851), where the editors concluded: "Any analysis of the symbols Mary used must remain largely a matter of conjecture; they were introduced for the purpose of concealment, and in this they are largely successful." 37

More of these dreams are preserved in a copy made by the learned Gísli Konráðsson (1787-1877) on Flatey á Breiðafirði (Lbs 1168 8vo), who explains that they derive from Sæmundur's booklet or diary fragment: "tínt saman eftir skræðu hans eður dagbókar rifrildi". ${ }^{38}$ The dreams are numbered from 1 to 61 , but 10,11 and 25 are lacking and 16 appears twice. The first dreams are dated April and May 1807, followed by those from January and February 1795 that appear consecutively in the autograph notebook. The rest are from the last months of 1819 and January 1820 . In total, 6500 words are devoted to these dreams, including 1600 words on those from 1795 .

These texts must be taken as they stand and should simply be trusted. They are certainly as plausible as any description of a dream can be. Sæmundur can have had no other purpose in recording his dreams than simply that of wishing to remember them and they were not part of his various quarrels or court cases. The only comment he ever made as to why he wrote down the dreams dates from the morning of 14 October 1819, after he had dreamt that a woman had dressed him up in an oversized, wet and slimy overall, made of shaven hides ("mikið stór og víður smokkur, slikjublautur og rakaður"). This could not signify anything bad, he commented, although it certainly looked ugly, as he placed no particular trust in any dream and was recording them to help try to understand their nature: "Ekki mun petta merkja illt, pó ljótt sýnist - ekki reiði eg mig uppá neinn draum, en skrifa pá til að ná peirra náttúru." ${ }^{39} \mathrm{He}$ was intrigued and he wanted to understand - and all that a modern reader can do, in the words of Lynn Struve, is to accept "the utter interiority of what is reported", and believe that "what is recorded bears some relation to what has been recalled from a spate of dreaming." 40

\footnotetext{
${ }^{37}$ The Journals of Mary Shelley II, 581.

${ }^{38}$ Draumadagbók Samundar Hólm, 100.

${ }^{39}$ Draumadagbók Samundar Hólm, 166.

${ }^{40}$ Struve, "Dreaming and Self-Search during the Ming Collapse", 164-165.
} 


\section{Fantasy dreams}

The diaries of William Laud (1573-1645), Archbishop of Canterbury, record numerous dreams in detail. At court, just before he was executed for treason and as his dreams were being used against him, he explained: "Dreams are not in the power of him that hath them, but in the unruliness of the fancy, which in broken sleeps wanders which way it pleases." ${ }^{41}$ In 1766, Jérôme Richard (b. 1720) explained that the strangeness of dreams was due to the fact that in sleep the soul was not in any contact with the world but had access to all previous experience and thought, mixing everything together in every conceivable way. ${ }^{42}$ Twenty years earlier, the German theologist Samuel Formey (1711-1797) had concluded that in dreams the soul certainly had feelings but was not affected by the environment: "éprouve des sensations, sans que les objets externes paroissent faire aucune impression sur elle." It could thus travel around the world, and things could either appear or disappear, and could be agreeable or disagreeable, or even both at the same time..$^{43}$

Such apparent incoherence is a strong characteristic of Sæmundur's dreams. His noctuary starts at the end of January 1794 in the middle of a sentence with a storm coming from the east and an enormous river flowing towards the southwest, with huge waterfalls, and with the earth shaking. A boy arrived, along with others whom Sæmundur did not see, and prepared to attack him with hostile words and cruel demeanour ("með illum orðum og drápsbragði”), but Sæmundur confronted him with anger and threats, and he disappeared. Next, Sæmundur was walking on a mountain and found fragment of a meteorite ("geimsteinn"), which he brought to his mother in a dimly-lit house. She received him with kindness and took the stone, which was the size of a fist, and struck something with it. A great fire erupted, again and again, for an extended period - and then he woke up: "vaknaði eg morguninn" ${ }^{44}$ Here we find a curious mixture of elements: nature, weather, angry but faceless people, and a mysterious stone, but also his mother. Similar contrasts are common, as when Sæmundur's former schoolmate at Skálholt, Benedikt Bogason (1749-1819), one of Iceland's wealthiest men, appeared to him, happy and bombastic, on the night

\footnotetext{
${ }^{41}$ Barbour, "Liturgy and Dreams in Seventeenth-Century England", 228-229.

${ }^{42}$ Richard, La théorie des songes, 81-84, 139-140.

${ }^{43}$ Formey, "Essai sur les songes", 174.

${ }^{44}$ Draumadagbók Samundar Hólm, 95. In what follows page numbers from this edition are put within parenthesis right after the citation.
} 
of 8 May 1794. Benedikt's head then removed itself without bleeding, placed itself at Sæmundur's feet and began talking gibberish: "pókti mér af honum verða sett höfuðið og blæddi ekki úr og settist höfuðið til fóta minna og var að tala einhverja heimsku." The head then returned to its correct place and only then did pus appear, causing Benedikt to prostrate himself face down. Sæmundur continued to dream, meeting his father in good spirits, and then visiting Copenhagen, where he saw the royal palace that had just burnt down (113).

In that same vein, in Nürnberg, Germany, the poet Sigmund von Birken (1626-1681) had dreams that were simultaneously realistic and disordered, as when, while preaching, he was suddenly unable say a word, or as when his head was cut off and placed on a pillow. On the night to 14 November 1677, he dreamt of brown worms and thought that this would result in wealth. ${ }^{45}$ In his dreams, Sæmundur himself often saw an impressive variety of worms that appeared and then vanished, at times in connection with food $(106,114,149)$; one of them even appeared in his faeces (146-147). As priest, Sæmundur must have been familiar with the plethora of dreams and revelations in the Bible and although it can not be seen in his letters or writings he may have been familiar with writings produced by theologians and other members of recent spiritual movements, such as the Swedish scientist Emanuel Swedenborg (1688-1772). Religious visions, however, are notable by their absence in Sæmundur's dreams, compared, for instance, with those described by Swedenborg (1688-1772), who started writing a diary while travelling through Holland in the spring of 1744, but was soon recording nothing but his dreams, which he interpreted immediately. On the night to 25 March, to take just one example, he descended a huge staircase towards a deep and apparently almost impassable chasm. There were people on the other side and he reached towards them with his hand in search of assistance. He then woke up and concluded that damnation might be awaiting him unless he sought help: "Voro på andra sidan personar, dem jag räckte handen att komma över. Vaknade. Är faran jag är uti att falla i avgrunden, om jag inte får hjälp." ${ }^{\prime 6}$

Such revelatory dreams appear in the autobiography of Sæmundur's benefactor the Rev. Jón Steingrímsson (1728-1791), most of them in the spirit of Swedenborg. To Jón, dreams always contained a message, in all

\footnotetext{
${ }^{45}$ Gantet, Der Traum in der frühen Neuzeit, 358-367.

${ }^{46}$ Swedenborg, Drömboken. Journalanteckningar 1743-1744, 12.
} 
likelihood from God, who would either warn or bless him, and he was supposed to share these visions with his wife and others. On the basis of Jón's texts alone, Adriënne Heijnen has concluded that in eighteenth-century Iceland dreams were "an accepted source of knowledge that provided guidelines for action among the common people and the clergy." ${ }^{77}$ This is a somewhat overstated claim. Although there is evidence that Sæmundur did discuss dreams with his workers and friends, he never saw them as guidance and refers to God only occasionally, when threatening his enemies with divine retribution $(126,138)$. On the other hand, once, on the night to 28 April 1794, the devil made an unsuccessful attack on him. Sæmundur was standing in darkness at some high location, from which, close by to the north, he saw the devil preparing an assault. Though barely able to see him in the dark, Sæmundur nonetheless he managed to repel him with great force; after further attacks the evil one finally disappeared into the ground: "eg bölvaði honum í burt með grimmilegum krafti, en hann kom upp aftur og aftur par til eg rak hann niður úr jörðinni og hvarf hann so að öllu." The gruesome-looking creature was pitch-black, had four legs and resembled a snake: "ferfættur með mjög ljótri ásýnd og dimmkolsvartur og nokkuð í höggormslíki" (111). We cannot, of course, say how Sæmundur discussed his dreams with friends and neighbours and he may certainly have intended his notes for later use as he wished to think more deaply about his nocturnal experiences, but if he had such thoughts he did not write them down.

\section{Current affairs}

A Chinese official, Xue Cai (1598-1665), recorded dreams extensively in his diary during a period of intense warfare in 1642-1645. Many directly related to current events, as he saw the spilling of blood, or imprisonment and great danger. He woke up trembling with fear. ${ }^{48}$ In 1699, a merchant in Mexico City, Diego Martínez de Arce, sensed a crisis in his religious beliefs and handed over to the inquisition a booklet containing descriptions of numerous dreams. Most of these concerned day to day affairs,

\footnotetext{
${ }^{47}$ Heijnen, The Social Life of Dreams, 82. On visionary dreams in Iceland in the seventeenth and eighteenth centuries, see Ólafur Davíðsson, Galdur og galdramál, 16-24.

${ }^{48}$ Struve, "Dreaming and Self-Search during the Ming Collapse", 163-164, 175-176.
} 
such as fraudulent merchandise and non-payment of debts. ${ }^{49}$ Sarah Morgan, a young woman in Louisiana, wrote down her dreams during the American Civil War, meeting with Shakespeare and Charlotte Brontë, but also flying in space. Her worst dream was that she was about to be married..$^{50}$ The soldier Alexander Paxton kept a diary of dreams for two months in 1864. He dreamt of fights and attending church, or, once, of harvesting potatoes as a sow approached, attacked and devoured him. ${ }^{51}$ Most of Sæmundur's dreams were also closely connected to his current situation at Helgafell and to the treatment he had already endured. On 28 January 1794, a merchant ship approached and, five nights later, the smithy burnt down, a terrible sight to see and one that continued for a long time (97). On 18 February, he had a vision of large fat foxes, brown and grey, who were not at all scared of him (99). Two nights later, he prepared to dig up Christ from what he thought was his grave at Helgafell church, to see whether the body had decayed: "pókti mér Krists líkami vera grafinn hér að kirkju og átti að fara að grafa hann upp til að vita hvort ei væri rotnaður" (104). On 14 September, Sæmundur was digging a deep hole "hér á Helgafelli" and it turned out to be full of water. An ugly worm then dropped from the sky, and disappeared into it as if dead (130). On 14 January 1795, Sæmundur found himself at the top of a mountain, building a house, and saw many birds there. One of the dogs at Helgafell, called Kolur, came along and bit the leg off one of the birds, whereupon Sæmundur struck him hard on the neck with a stick so he howled and ran away (158). On 25 January, we find Sæmundur preparing to cut grass with a sword (159).

His enemies, Björn (the provost) and Hallgrímur (the physician) featured regularly in the dreams. On the night of 4 February, Sæmundur dreamt of Hallgrímur inspecting corpses and coffins (96). Six nights later, Sæmundur was in Copenhagen, showing the Helgafell assessment of 1781 to Jón Eiríksson, who claimed that Sæmundur would prevail in his dispute. Björn arrived, a diminutive figure looking grey and tired, and saying nothing: "leit illa út grár, gugginn og lítill og pagði" (98). On the night of 11 April, Sæmundur was at Staðarholt writing as Björn arrived to persecute him. Sæmundur escaped by running away. Björn appeared again but eventually cleared off and dawn broke: "seinast hvarf hann eða snáfaði í burtu, bjart

\footnotetext{
${ }^{49}$ Jordán Arroyo, Entre la vigilia y el sueño, 156-160, 163-183.

${ }^{50}$ White, Midnight in America, 76-78.

${ }^{51}$ White, Midnight in America, 45.
} 
varð” (108). On 9 May, Sæmundur fought with three or more ugly-looking men in a dark house but managed to overcome all of them. As they vanished, Hallgrímur arrived and praised Sæmundur, who did not reply. This dream continued with Sæmundur on a hill, where he kept three somewhat rusty canons, that were meant to be used for killing his enemies (114).

On 9 June, Sæmundur was digging vigorously in the ground looking for somewhere to hide, as he felt that he was not safe anywhere: "til að leita mér fylgsna, pví mér pókti varla neinstaðar vært" (117). Five nights later, Björn made an unsuccessful claim for money before disappearing, small of stature and ugly in aspect (119). On 3 July, both men were present. Björn tried to crawl under Sæmundur's coat ("smjúga undir kápu mína"), whispering that he should drop his accusations and show some fairness. Sæmundur was silent, and then Hallgrímur arrived, walking between them, all the while talking and shouting (120). On 12 August, Sæmundur found himself in a big house, well supplied with food and drink, and was able to eat and drink at his pleasure. Björn did his best to prevent him from doing so, but without success (124). On 26 October, Hallgrímur returned, unsettling and antagonistic as ever, though with no justification: "eins og hann plagar fullur með óeirð og fjandskap af öngri nauð." Sæmundur surprised himself by just how harshly he addressed his antagonist; in his account he remembered just these words:

I am innocent but you never tire of persecuting me, with your deceitful evil. I wish you all well, you wish me all evil, and you will keep on with this until death, you wretched crook. The devil is blinding you more and more to do some terrible deed, but you will learn, if you continue in this way, that such devilish behaviour will be your destruction and damnation, and you will never defeat me. Satan will make you mad before you die. Just look what is happening to you; but your stubborn and evil pride stops you from seeing this until eventually you will go to hell, for the punishment of god will descend on you.

(Pér leiðist ekki að ofsækja mig saklausan og pinni lygafullri vonsku, eg vil pér allt gott, pú vilt mér allt illt, í pessu heldur æáfram til dauðans pinn bölvaður skálkur, andskotinn forblindar pig æ meir so pú vinnir eitt staklegt níðingsverk, en pú munt reyna, ef pú so áfram heldur, að petta djöfulsins athæfi verður pín bölvan og foreyðing og pinna, en færð ei á mér unnið. Andskotinn ærir pig í bölvaninni áđur en pú drepst, sjáðu hvar pú ert aðkominn en pú sérð pað ekki fyrir pínu forstokkuðu og skálkafullu bölvuðu drambi inntil pú ferð seinast til helvítis, pví straff guðs mun með pessu móti á pér bitna.)

Hallgrímur said nothing, faded away and finally disappeared (137-138). However, not all Sæmundur's interactions with his enemies were bad. 
On the night to 3 November 1794, just after Sæmundur had sent his seven questions to Björn (see here on p. 131), he dreamt that they were working together on sailing a raft on a lake (139). On 11 December, they collaborated on fixing a door (142), and on 24 January 1795 Sæmundur found himself to be married to Björn's sister, though he did not know her name: "ei vissi eg hvað hét” (159).

\section{Copenhagen}

There is no doubt that Sæmundur missed Copenhagen, having lived there for fifteen years, although one could say that he did not get the opportunities that he deserved. On the night to 21 February, he was present at a house where King Christian VII was sitting with his government. Sæmundur was asked to eat with them, which he did, mostly enjoying a sweet and tasty green dish in the form of bread. He wore the same scarlet clothes as the king and most of the other courtiers; it was bright daylight and they did not speak: "Var í skarlatsrauðum klæðum og eins kóngur og flestir við pað borð, vel bjart var, ei töluðum vær neitt" (104-105). On 30 July, he again spoke with the king and the crown prince on various matters (123), apparently with great satisfaction. At the time of Sæmundur's departure, Copenhagen was a thriving city of 90,000 inhabitants, with a rich cultural life and a major university, although the common people lived in cramped quarters, many of them in great poverty. ${ }^{52}$ On the night to 30 January 1794, he was at the house of a police officer by the name of Leth, whose wife and son were also present, along with three other unknown and scruffily dressed boys. The couple offered him fine food which he hardly touched. The weather was cold and though Sæmundur was well dressed, he was barefoot and his feet were dirty. He woke up only to fall asleep again after dawn ("eftir birtingu"), dreaming that he was back in the garden of the house where had lived in the years 17811789, at 268 Aabenraa Street, gazing at what appeared to be a basin filled with hides: "í garðinum, sá [drawing] fullt með [drawing]" (see image 2). A naked boy came and stepped into it before heading back to his bed.

${ }^{52}$ Henningsen and Langen, Hundemordet $i$ Vimmelskaftet, 19-27, 194-196; Munck, "Keeping the Peace: 'Good Police' and the Civic Order in 18th-century Copenhagen"; Matthiessen, Københavnske gader 1728-1795, 7-33, 80-86, 104-134; Guðjón Friðriksson and Jón P. Pór, Kaupmannahöfn sem höfuðborg Íslands I, 385-410, 456-463. 
Sæmundur also felt the urge to try out the basin, sensing that he really was present there (95). On 14 February, he returned and saw many wet hides that had been treated, some folded and some spread out, and also observed many basins filled with water and hides: "sá margar bereiddar húðir blautar, sumar samanvafðar sumar útbreiddar, og mörg ker stór full af vatni og húðum" (98). Aabenraa Street is situated in the neighbourhood between the Round Tower and the Rosenborg Castle. According to a 1787 census, four families lived in the building along with several tenants, twenty people in all. Sæmundur rented a room with a tailor and his wife. A buttonmaker and a shoemaker also lived there, but the most striking activity, if the dream is to be believed, was a tannery kept by a certain Jensen and his wife Karen Axt. At this time, there were at least three tanneries in the city, employing dozens of people. ${ }^{53}$ This tannery made a lasting impression on Sæmundur, and at some point he must have undertaken work there, learning the tricks of the trade as he did so. Hides were amongst his strongest preoccupations in dreams.

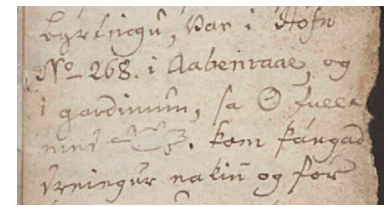

Image 2.

\section{January 1794}

Var í Höfn No. 268 í Aabenraae, og í garðinum, sá [drawing] fullt með [drawing]. Kom pangað drengur nakinn og fór par í og upp aftur og inn í rúm til sín (95).

On 2 April, he found himself at Aabenraa 268, observing basins with hides and water, again as if actually present, and depicting other items as a cluster of dots and a bone; he expressed regret at having ever left for Helgafell: "og iðraði af för hingað” (see image 3). On 5 May, everything was as before and he again stepped into a basin with water, remaining there for a long time and becoming like an L, which seems incomprehensible (see image 4). On the following night, he was in the garden; there were plenty of basins to be seen and there were hides in the basins and also lying around, perhaps unfolded, and as big as the basin themselves (image 5). He then went to visit Madame Axt, whose mother, Madame Petersen, was present; she gave him some books on medicine, teadrinking and other such matters: "um læknirsdóma, um theevatns brúkun og soddan" (112).

\footnotetext{
${ }^{53}$ Bruun, Kjøbenhavn III, 81-82, 553.
} 


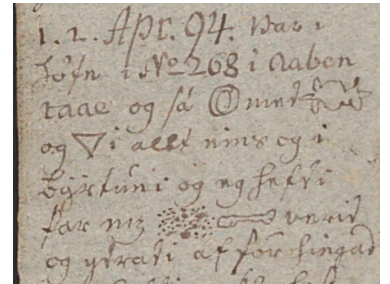

Image 3.

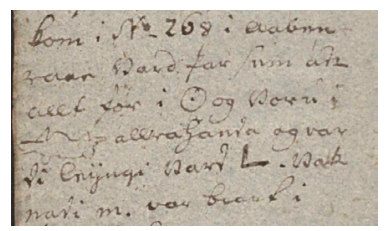

Image 4.

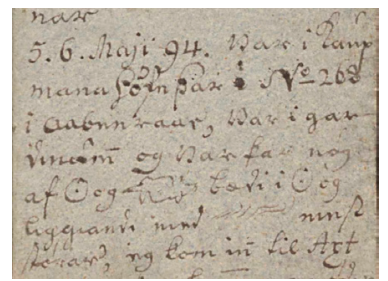

Image 5 .

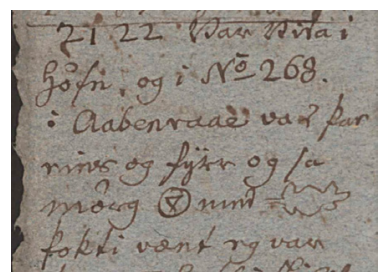

\section{December 1794}

Var víða í Höfn og í No. 268 Aabenraae var par eins og fyrr og sá mörg [drawing] með [drawing]. Pókti vænt eg var par en hafði skilið eftir mín skrif í Íslandi, var sem um miðjan vetur hafði lítið, vel klæddur (146).

Image 6 .

On 30 July, he was yet again at the tannery, working with others and enjoying the experience: "var sjálfur innanum pað með öðrum, er mér pókti gaman." As he met the Axt and Petersen ladies, he was tall and well dressed but without a hat: "eg var hár og vel búinn en hafði ei hatt." 
Everything was as it had been before, but this time the tannery was much bigger and better, and he thought that he had some part in this: "og garfaríið mikið meira og betra er eg og póktist hafa part 1̂" (123). A month later, he was in the room where he had spent most of his time in the city: "Var eg í pví sama kamersi og eg var í lengst í Höfn í No. 268." It was dark and he opened a window; it was raining outside, with a wind from the southeast. Someone walked up the staircase into another house: "gekk einhver upp tröppurnar í annað hús." He woke up but soon went back to sleep and dreamt that he was by a river in Iceland, north of Staðarholt, and had three horsehides with him. He made a hole in the ice that covered the river and put the hides into the water to keep them for later, although they were wet already, and one of them had no hair: "voru pó blautar og ein hárlaus ætlaði að geyma pær par í til síðan” (127). On 22 December, he was in the tannery and saw several basins with hides and enoyed being there but had left all his writings in Iceland. It was in the middle of winter and he had little money, but was nevertheless well dressed (image 6).

In fact, not all Sæmundur's dreams of Copenhagen were entirely positive. On 15 September, he found himself walking there and nobody paid him any attention. The city was almost empty of people and in a chaotic state: "var borgin nær auð af fólki og allt í ráðleysu". He was thinking about his published writings ("var að penkja eftir um prent mitt") but had none of them with him, was barefoot and badly dressed - it was as if for him everything was dead and defeated, with uncertainty as to what lay ahead: "var allt samt sem dautt fyrir mér og lágt hvað í veginn vildi koma." Then he donned fine new socks and decent shoes, also bright green ("fagurgrænar") trousers and vest, and was now well dressed (130). On 12 December, he saw torn-down houses whose black gables were still standing; the streets were damp and there was no one in sight: "sá húsin niðurrifin og stóðu upp gaflhlöðin svört var blautt á götum og svart og ei sá eg nokkurn" (143). These were fleeting moments and for the most part, as we have seen, Sæmundur wished that he had never left. On 9 April, he was at Staðarholt and stepped outside into the dark; a full moon shone to the east, and the place seemed a complete dump ("moldarbæli"). $\mathrm{He}$ then found himself by the sea, dark and wild, with a great river flowing from the north - and then he was on horse, heading for Copenhagen, deep in the water but with his feet still dry: "djúpsyndur og fóru fæur mínar ofaní en vöknuðu ekkirt" (107). On the night of 28 December, he was in church together with some of his teachers at the Royal Academy of Arts. He was given a marvellous illustrated book and expressed regret 
that he had left the city and come to the dreadful slavery at Helgafell in which he now found himself: "eg átti bókina, og iðraðist að eg fór paðan í pennan dauðans prældóm sem eg nú er î" (149). On 7 January 1795, Sæmundur heard someone calling outside the window, asking for something in monosyllables that made no sense: "Eg vænti pessa nakdeil ampu, amru ampu, meir en vel, hei, hei, hei, hey, meir en vel, pí, pí, pí, pí”. He woke up but dreamt further that he was at Aabenraa 268, where a bitch was lying with her puppies. One of them attacked him and he beat it away. He was well dressed, in black, and there were workers around. A large and beautiful woman approached him, saying that he hadn't been there for a long time, but that he had now returned and they were pleased to see him. He was welcome to stay and would have a good time; nobody would interfere with this: "Vertu velkominn hingað og langt er síðan eg sá pig hér og pú komst, nú ertu aftur kominn, pað gleður oss, og pú mátt vera hér, og pú skalt hafa gott hvar pú ert. Pað verður ei hindrað etc.” It was bright and everything looked natural, and then he woke up from this into the usual slavery: "Bjart var og allt náttúrlegt, og eg vaknaði frá pessu í prældóminn" (156-157).

\section{Youth}

In the spring of 1783 , Sæmundur wrote an essay in Danish about his health, including a description of accidents and other misfortunes that had befallen him in his youth (Lbs 817 8vo). At the age of three, he fell from a bed onto his head and later, aged nine, a huge pus-filled lump developed on his right thigh. He also describes a shocking episode at school in Skálholt, when he was sexually assaulted. There were some 35 students at the school and most of them slept in a common room, 32 square meters in size. Normally, two boys would share a bed, sometimes even three. Sæmundur states that he was twenty years old at the time and had just gone to bed. The boy with whom he shared a bed approached and then jumped on him and began to masturbate him: "begyndte at manustuprere mig". Sæmundur was unable to move and lost all strength after the other boy had finished his assault: "fuldbyrdet sit öyemed". Sæmundur asked his assailant why he had done this and threatened him but there was no reply: "hörte med taushed og foragtende koldsyndighed". His brother was present but said nothing either. Sæmundur was afraid to report the attack 
and the two young men continued to share a bed throughout the winter, with Sæmundur sometimes being woken up by the other's activities: "hans övelse". At the time of writing he was haunted by such episodes (200). If he ever dreamt of this in 1794 he did not write it down, but it would be possible to connect the two dreams related to Skálholt with Sæmundur's feelings of vulnerability as a young man, as in one of them he appears half-naked and in the other he is the victim of an assault. On 17 March, he was at school and supposed to recite from the New Testament. The prospect of this worried him and he had no book. The volume then appeared and he sat down, and was not wearing trousers until he started putting them on slowly: "settist niður, en var ei í buxum, fór pá í hægri skálmina en ei so brátt í hina". Bjarni Jónsson, the rector, was present, Sæmundur held his right hand but did not recite anything, and others then took over (103-104). On 23 June, he was going to school and was troubled that he could remember nothing from the New Testament. As a result, he failed to turn up at school, while all the other schoolboys did. He somehow felt superior to them, as if he had already graduated. Someone told him not to worry about being absent, since he had achieved good results in his studies, and done better than those who had bullied him; they would suffer in due course and be punished: "vertu ei áhyggjusamur pú parft aldrei meir að fara í skóla, pú hefur pað vel aflokið og framar hinum öllum sem vilja pig pvinga, pví peir eiga sjálfir pvingun að líða, peir gjöra fordjörfun og skaða og hefndin skal yfir pá falla" (120).

Another likely benefactor in Sæmundur's early life was the Rev. Björn Jónsson (1736-1808) at Hólmasel, who had come to the parish in 1761, before fleeing in June 1783 when Skaftáreldar began. On the night to 21 February 1794, Sæmundur was in a house with large windows, facing the east, and with the wind howling and the snow falling outside; the young man was shaking with fear. Sitting beside him was Björn, eating voraciously, so that Sæmundur had to feed himself as best he could: "dró allt frá mér, eg tók pá frá honum pað ætlaði eg mér" (100). On 13 March, Sæmundur was at Hólmasel and entered a garden belonging to Björn (103). On 28 September, Björn was preaching in a church in a hoarse voice ("hás mjög") so that he could hardly be heard (133). Then, on 10 October, he found himself once more at the burnt-out Hólmasel farmstead, on a Sunday. Björn was also present and everything was just as before, on a beautiful summer's day: "par var eins og áður; fagurt og sumar" (135). Finally, on 29 October, festivities were being prepared at Hólmasel and Sæmundur spotted Björn's cassock hanging outside at the 
entrance to the house. The garment fell to the ground and nobody picked it up: "datt niður og tók enginn upp" (141).

Sæmundur's parents figure in many dreams, a few of which have already been mentioned. His mother accepted the stone from outer space (see p. 135) and two weeks later she was with him in Copenhagen (98). On 4 October, Sæmundur trudged with difficulty through deep snow and slush, until she came to his aid: "Óð djúpan snjó og krapa og komst ei áfram en móðir mín kom par og hjálpaði mér" (134). On 17 November, Sæmundur had a dream that can be related to his father's having had two children out of wedlock. According to the law, Magnús should have been flogged after the birth of the second child, but on 1 August 1768 he applied for exemption from this penalty, and may well have been successful. In the dream, Sæmundur spotted a child on his left who rather resembled his father. There was also a woman looking on, whom, initially, Sæmundur failed to recognise as his mother. Nobody spoke: "faðir minn var innar á palli mín megin og barn við mína vinstri síðu nokkuð frá líkt honum nokkuð, móðir mín sneri að pví en leit ei upp, við töluðum ekkirt. Hún var rétt eins og í lifanda lífi að öllu að sjá, meinti eg annars pað væri í fyrstu önnur kona" (139).

We may suppose that Sæmundur entertained somewhat ambivalent feelings towards his father, but the fact that he was determined to travel to Iceland in 1786 shows that there was an abiding affection. In some dreams father and son collaborated, as on 19 March, when Sæmundur came to Hvoll í Mýrdal with his father. They went towards the sea and climbed over a stone wall that had been built as a barrier to the sea. As the two headed back, the sea surrounded Sæmundur and he was unable to reach land: "sjór flóði kring mig; komst ei aftur uppá land" (104). On other occasions, they travelled together, as on 6 September, when they headed to the north from Staðarholt, with Sæmundur riding a horse with the ability to speak; the animal assured his rider that he would always be there for him, so he would never need to walk again: "og sagðist skyldu so bera mig að eg ei pyrfti framar að vera gangandi” (128). On 27 October, Sæmundur was at Staðarholt and journeyed to a lake to the north of the farm, where he had set hides in water and mud. Thunder and a snowstorm seemed imminent; his father was there and then walked away (137). On 12 November, Sæmundur helped his father feed hay to their sheep, and there is a detailed description of how plentiful the available supplies of fodder were. Again, neither of them did speak: "en ei töluðum við" (142). In these dreams, father and son were on an equal footing and only once 
did Sæmundur do a better job. This was on the night to 22 December, as he stood on a peninsula by Hvammsfjörður, not far from Helgafell, and two women came towards him on horseback. As they traversed a small bay ("vogur") a sudden storm caused the sea to rise ("og belgdi að sjónum með brimi"), so that one of the horses fell and the woman disappeared. His father came along and thought that she had drowned, whereas $\mathbf{S}$ mundur waded into the sea ("synti útí brimið”) and saved her: "náði henni lifandi á purrt land" (147).

The fear of his father's death appears in several of Sæmundur's dreams. On 12 February, he was in a house with his father, who was in ill health, which worried Sæmundur, who feared that he would die. These anxieties troubled him; it was as if he did not know that his father was already dead: "bví eg sem vissi ei að hann var dauður" (98). On 18 September, Sæmundur walked out of a house towards a stack of hay, where his father was sitting. He asked whether he was in pain: "er pér illt?" The father replied that he was not, and after Sæmundur enquired further as to how he was feeling, the reply was brief: "nógu vel" (well enough). He looked different and this made Sæmundur unhappy: "pað ógladdi mig" (131).

\section{Concluding remarks}

What did Sæmundur's dreams signify? The recurring themes described here reflected either his worries and quarrels in daily life at Helgafell or they echoed childhood memories and his longing for some sort of return to his former life in Copenhagen. A closer reading of single dreams or a series of his dreams in the context of modern psychological theories would be an interesting next step, but with caution. In the eighteenthcentury, numerous manuals for the interpretation of dreams were published, all rather superficial. To dream of a snakebite, for instance, meant that "danger will befall you by secret and subtle enemies." ${ }^{54}$ An Icelandic manuscript from the latter part of the century (Lbs 624 4to) contains many such readings, explaining that dreams were useful when the blood stood still: "pá blóð er vel stillt og hefur skikkað sér í sinn stað, og maður hefur

\footnotetext{
${ }^{54}$ Rivière, Dreams in Early Modern England, 60-62, 73-74; cf. Ford, Coleridge on dreaming, 14-15, 26.
} 
kastað af sér vatni, og sofnar síðan." 55 Out of the hundreds of items listed, only a few correspond to anything that occurred in Sæmundur's dreams. To see one's mother alive was a positive sign and signified gladness: "Pað merkir glaðværð og gott teikn” (178). To see or talk to one's enemies meant that the dreamer would need to take care and be watchful (181). To see a severed human head pointed towards dishonour and illness for that individual (182). To kill a snake meant overcoming all one's enemies (184).

Sæmundur would probably have found such readings superficial and as for his own dreams, he hardly ever bothered to interpret them - at least on paper. Generally speaking, his dreams were an instance of what the second century Greek author Artemidorus characterized as "enhypnion" as opposed to "oneiros". A hungry man dreams of eating and a thirsty man dreams of drinking; this was "enhypnion" and such dreams vanished as soon as sleep was over. They meant nothing. The more interesting "oneiros", however, operated "by bringing to our attention a prediction of future events". After sleep, it would alert and excite the mind ${ }^{56}$ Such predictive dreams, it should be mentioned, are a common feature in Icelandic medieval literature and Sæmundur certainly was familiar with many of those texts, as some of his poetry relates events that happened in the first century of the country's history, but he never refers to them of imitates any. ${ }^{57}$ Only twice in 1794 he predicted bad weather $(101,112)$ but also war and his own longevity $(132,136)$. Again, we do not know how he talked about his dreams. In his later notes, the predictive element is a little stronger, as he continued to dream about Björn Porgrímsson and Hallgrímur Backmann, as well as his parents, Staðarholt and Copenhagen. On 20 April 1807, Sæmundur dreamt of an ice-covered river; he undressed and jumped into the water, only to find that the water was warm and contained a variety of hides ("slikjublautar húðir"). He swam along for some time and he commented that this meant the onset of good weather (152). On 19 September 1819, he had the "natural but ridiculous" ("náttúrlegan en afkáralegan") dream of being in bed, but feeling the wet hide of a horse

\footnotetext{
${ }^{55}$ Lbs. Lbs 624 4to. Safnrit frá um 1770, 438-439. On the manuscript, see Runica Manuscripta: die Nordische Tradition.

${ }^{56}$ Artemidorus, The Interpretation of Dreams, 4-5; cf. Thonemann, An Ancient Dream Manual, 34.

${ }^{57}$ The first chapters of Heijnen, The Social Life of Dreams, discuss medieval Icelandic literature; see also Crocker, "Disability and dreams in the medieval Icelandic Sagas"; Helga Kress, Óparfar unnustur og aðrar greinar um íslenskar bókmenntir, 30-45.
} 
("blaut hrosshá") at his feet. This indicated that things would develop in a positive way, even though he thought that this was unlikely: "Petta merkir mér gengur eitthvað í vil til framgangs, pó ólíklegt sé" (164). But, as we have already noted, on 14 October 1819 he explained that he was only interested in understanding the nature of dreams (see p. 134), and on 28 December that year, after having dreamt of a certain configuration of the moon, he concluded that he did not trust dreams: "Ekki set ég traust á drauma" (172). In his old age, Sæmundur would not have been absolutely certain, and yet, in his penultimate extant dream on 3 January 1820 , he saw a blackened piece of old meat ("svarta flygsu") and many worms from fish ("fiskmaðkar"), some of them half-dead and unable to move: "en peir komust ekkert". He then produced a clear (and, for him, advantageous) interpretation: the worms were his enemies and they would not escape: "Petta er fyrir mínum óvinum, og munu ekkert komast" (172). Thus, at seventy, his dreams still served for him as a safe haven, whereby he could either revisit his childhood and his years in Copenhagen, where he would have had more opportunities to practice his art and meet with other artists and thinkers, or find reconciliation with his enemies - or, even better, to beat them.

\section{Bibliography}

\section{Manuscripts}

National Archives, Denmark (NAD).

Royal Academy. Akademiforsamlingen. Journalsager 1.2-3. Indkomne breve 1779-1788

National Archives, Iceland (PÍ.)

Kanselli (KA)

KA/32. Innkomin bréf og önnur skjöl 1784.

KA/40. Innkomin bréf og önnur skjöl 1788.

KA/42. Innkomin bréf og önnur skjöl 1789.

KA/48. Innkomin bréf og önnur skjöl 1792.

KA/57. Innkomin bréf og önnur skjöl 1798. 
Rentukammer (Rtk.)

B7/2. Bréfadagbók 3 .

B11/5. Bréfadagbók 7.

B12/5. Bréfadagbók 8 .

Skjalasafn stiftamtmanns (Stift.)

I-23. Bréfabók 1787-1788.

I-24. Bréfabók 1789-1791.

III-59. Bréf Skálholtsbiskups til stiftamtmanns 1793-1796.

Biskupsskjalasafn (Bps.)

A-IV, 18. Bréfabók Skálholts 1770-1773.

A-IV, 28. Bréfabók Skálholts 1789-1790.

A-IV, 30. Bréfabók Skálholts 1793-1795.

A-IV, 31. Bréfabók Skálholts 1795-1798.

A-IV, 34. Konungsbréfa- og kollegíalbréfabók 1747-1792.

A-IV, 40. Kansellíbréf til Skálholtsbiskups 1742-1801.

Sýsluskjalasafn (Sýsl.)

Snæfellsnessýsla (Snæf.)

EC1/1,2. Uppboðsbók 1819-1834.

ED1/2, 1. Skiptabók 1822-1834.

ED2/3. Dánarbú 1811-1833.

Hannes Porsteinsson, Effir lardra manna. Accessible on-line at the Archive's website, http://skjalaskrar.skjalasafn.is/r/NjQxOTA1.

\section{Manuscript department of the National Library of Iceland (Lbs.)}

Lbs 27b fol. Bréfasafn Hannesar Finnssonar.

Lbs 28 fol. Bréfasafn Hannesar Finnssonar.

Lbs 624 4to. Safnrit með hendi Jóns Egilssonar á Vatnshorni um 1770.

Lbs 817 8vo. Safnrit, par á meðal sjúkrasaga Sæmundar Hólm með eigin hendi.

Lbs 1168 8vo. Draumar og kvæði Sæmundar Hólm með hendi Gísla Konrádssonar.

JS 317 8vo. Kvæðasafn Sæmundar Hólm með eigin hendi.

JS 318 8vo. Kvæðasafn og draumadagbók Sæmundar Hólm með eigin hendi.

\section{Printed works}

Arroyo, María V. Jordán, 2017: Entre la vigilia y el sueño. Soñar en el Siglo de Oro. Madrid: Iberoamericana. 
Barbour, Reid, 1991: "Liturgy and Dreams in Seventeenth-Century England". Modern Philology 88:3. Pp. 227-242.

Bricka, C.F., 1887-1905: Dansk biografisk lexikon. 19. bind. Copenhagen: Gyldendal. <runeberg.org/dbl>.

Bruun, Carl, 1887-1901: Kjøbenhavn, en illustreret Skildring af dens Historie, Mindesmarker og Institutioner. Three vols. Copenhagen: P.G. Philipsen. <www.eremit.dk/ebog/bkh/index.html>.

Crocker, Christopher, 2019: "Disability and dreams in the medieval Icelandic Sagas”. Saga-book 43. Pp. 37-58.

Ford, Jennifer, 1998: Coleridge on dreaming. Romanticism, dreams, and the medical imagination. Cambridge \& New York: Cambridge University Press.

Formey, Samuel, 1754: "Essai sur les songes". Mélanges philosophiques I. Leyden: Elie Luzac fils. Pp. 174-204.

Gantet, Claire, 2010: Der Traum in der frühen Neuzeit. Ansätze zu einer kulturellen Wissenschaftsgeschichte. Berlin \& New York: De Gruyter.

Gísli Ágúst Gunnlaugsson, 1984: "Viðbrögð stjórnvalda í Kaupmannahöfn við Skaftáreldum”. Skaftáreldar 1783-1784. Ritgerðir og heimildir. Reykjavík: Mál og menning. Pp. 187-214.

Guðjón Friðriksson and Jón P. Pór, 2013: Kaupmannahöfn sem höfuðborg Íslands. Two vols. Reykjavík: Hið íslenska bókmenntafélag.

Hannes Porsteinsson, 1907-1910: Guðfræeðingatal. Reykjavík: Sögufélag.

Haraldur Sigurðsson, 1972: "Sæmundur Magnússon Hólm og kortagerð hans". Árbók Landsbókasafns Íslands 29. Pp. 136-152.

Heijnen, Adriënne, 2013: The Social Life of Dreams. A Thousand Years of Negotiated Meaning in Iceland. Vienna \& Berlin: Lit Verlag.

"Heimildir til sögu Skaftárelda og Móðuharðinda 1783-1785". Skaftáreldar 1783-1784. Ritgerðir og heimildir. Reykjavík: Mál og menning 1984. Pp. $265-435$.

Helga Kress, 2009: Óparfar unnustur og aðrar greinar um íslenskar bókmenntir. Reykjavík: Bókmennta- og listfræðistofnun Háskóla Íslands.

Henningsen, Peter, and Ulrik Langen, 2010: Hundemordet $i$ Vimmelskaftet - og andre fortallinger fra 1700-tallets Kфbenhavn. Copenhagen: Jyllands-Postens Forlag.

Íslenzkar aviskrár. Six vols. Editors Páll Eggert Ólason and Jón Guðnason. Reykjavík: Hið íslenzka bókmenntafélag 1948-1976.

Katalog over de oldnorsk-islandske håndskrifter $i$ det store kongelige bibliotek og i universitetsbiblioteket. Editor Kristian Kålund. Copenhagen: Gyldendal 1900.

Kiфbenhavns Adresse-Contoirs Efterretninger, May 4 and 18, 1784.

Kiøbenhavnske Tidender, September 8, 1783.

Matthiessen, Hugo, 1924: Københavnske gader 1728-1795. Kulturhistoriske studier. Copenhagen: H.P. Madsens Boghandel.

Matthías Pórðarson, 1920-1925: Íslenzkir listamenn. Two vols. Reykjavík: Gutenberg. 
Már Jónsson, 2019: “Sorgarviðbrögð Sæmundar Hólm vegna Skaftárelda”. Ólöf Garðarsdóttir et al. (eds), Nýtt Helgakver. Rit til heiðurs Helga Skúla Kjartanssyni sjötugum. Reykjavík: Sögufélag. Pp. 167-181.

Munck, Thomas, 2007: “Keeping the Peace: 'Good Police' and the Civic Order in 18th-century Copenhagen”. Scandinavian Journal of History 32:1. Pp. 38-62.

Ólafur Olavius, 1965: Ferðabók. Two vols. Translator Steindór Steindórsson. Reykjavík: Bókfellsútgáfan.

Richard, Jérôme, 1766: La théorie des songes. Paris: Les Frères Estienne.

Rivière, Janine, 2017: Dreams in Early Modern England: Visions of the Night. London \& New York: Routledge.

Runica Manuscripta: Die Nordische Tradition. Editors Alessia Bauer and Wilhelm Heizmann. Berlin \& Boston: De Gruyter 2019.

Sigurður Pórarinsson, 1984: “Annáll Skaftárelda”. Skaftáreldar 1783-1784. Ritgerðir og heimildir. Reykjavík: Mál og menning. Pp. 11-36.

Struve, Lynn A., 2007: "Dreaming and Self-Search during the Ming Collapse: The Xue Xiemeng Biji, 1642-1646”. T'oung Pao 93. Pp. 159-192.

Sveinbjörn Rafnsson, 1984: "Um eldritin 1783-1788". Skaftáreldar 1783-1784. Ritgerðir og heimildir. Reykjavík: Mál og menning. Pp. 242-262.

Swedenborg, Emanuel, [1995]: Drömboken. Journalanteckningar 1743-1744. Editor Per-Erik Wahlund. Stockholm: Wahlström \& Widstrand.

Sæmundur Hólm, 1780 and 1781: "Um meltakið í vesturparti Skaftafellssýslu". Rit pess íslenska lardómslistafélags I (1780), pp. 26-60; II (1781), pp. 139-167.

- $1794:$ Om Jordbranden paa Island. Copenhagen.

The journals of Mary Shelley 1814-1844. Two vols. Editors Paula R. Feldman and Diana Scott-Kilvert. Oxford: Clarendon Press 1987.

The Oxford Classical Dictionary. Editors Simon Hornblower and Antony Spawforth. Oxford: Oxford University Press 1999.

Tønnesen, Allan, 1988: København før og nu-og aldrig IV. Nord for Strøget. Copenhagen: Palle Fogtdal.

“Úr ferðabók Steingríms Jónssonar á vísitasíum með Hannesi Finnssyni Skálholtsbiskupi”. Editor Veturliði Óskarsson. Skírnir 192 (spring 2018). Pp. 75-104.

White, Jonathan W., 2017: Midnight in America. Darkness, sleep, and dreams during the Civil War. Chapel Hill: The University of North Carolina Press.

Porleifur Einarsson and Edda Lilja Sveinsdóttir, 1984: "Nýtt kort af Skaftáreldahrauni og Lakagígum”. Skaftáreldar 1783-1784. Ritgerðir og heimildir. Reykjavík: Mál og menning. Pp. 37-48.

Porvaldur Thoroddsen, [2003-2009]: Landfraeðissaga Íslands. Four vols. Reykjavík: Ormstunga.

\section{World Wide Web}

Det Kgl. Biblioteks mediesamlinger, http://www2.statsbiblioteket.dk/ mediestream/avis/ 
The genealogical database Íslendingabók, https://islendingabok.is

Manuscript web of Landsbókasafn Íslands-Háskólabókasafn, Stofnun Árna Magnússonar and Det Arnamagnæanske Institut, https://handrit.is

Vilhjálmur Örn Vilhjálmsson, "Furðumyndir frá 18. öld á Listasafni Íslands: Fyrri hluti”, https://fornleifur.blog.is/blog/fornleifur/entry/1268939/ (published 18th November 2012)

__ , "Furðumyndir frá 18. öld á Listasafni Íslands: Síðari hluti”, fornleifur.blog. is/blog/ fornleifur/entry/1268942 (published 24th November 2012)

__, "Eldgosamyndir Sæmundar Hólm", https://fornleifur.blog.is/blog/fornleifur/ entry/1438512 (published 4th September 2014)

\begin{abstract}
The Rev. Sæmundur Magnússon Hólm (1749-1821) is mostly known for portraits of prominent Icelanders as well as for several colourful pictures of volcanoes and phantasmagoric landscapes. He spent fifteen years in Copenhagen where he studied theology at the University and fine arts at the Royal Academy of Arts - the first Icelander to graduate from that school. He wrote some poetry, most of it still unpublished, but the most noteworthy item of his writings is a notebook containing a diary of his dreams or noctuary, preserved from the year 1794. Indeed, Sæmundur seems to have made such notes over many decades, though only this notebook and a few later accounts survive. These texts have now been published and this article presents an overview of their contents as they relate to Sæmundur Hólm's life and works, most importantly the period from his traumatic arrival at the parish of Helgafell in the autumn of 1789 to his dreams of 1794. Most of those dreams concerned his worries and quarrels in daily life at Helgafell, some of them interspersed with fantastic elements, or they echoed childhood memories or his longing for some sort of return to his former and more enjoyable life in Copenhagen. Very few of them are meant to be predictive and hardly any contain religious undertones. Numerous of the dreams are illustrated with small and simple drawings or signs, a few of them included here.
\end{abstract}

Keywords: Iceland, Copenhagen, eighteenth century, Sæmundur Hólm, dreams, sexual abuse

Már Jónsson

University of Iceland

Árnagarði v/Suðurgötu

101 Reykjavík

marj@hi.is

ORCID iD 0000-0003-4891-4154 



\title{
Christian Medieval Art in Norse Greenland Crosses and Crucifixes and their European Antecedents
}

\author{
EBbe Nyborg AND JeTte ARnEBORG
}

\section{Introduction}

It is well known that the Norse inhabitants of Greenland contributed to the art of the Middle Ages by supplying raw materials in the form of walrus and narwhal ivory for exclusive carving in Europe (Roesdahl 1995 and 1998, Frei et al. 2015, Star et al. 2018, Barrett et al. 2019). But the Norse population also developed in artistic terms, albeit at a different, more modest level. A significant number of the wooden crosses, which were mainly found in association with churchyard graves and of which seven bear runic inscriptions, are simple. However, amongst them are four crosses with details, which despite their simplicity, exhibit traits that can be cautiously identified in European prototypes, and the same applies to two crucifixions. The main sections of this article will describe and analyse these six objects and their European antecedents. Dating is a problematic area. How long a delay in the stylistic traits was there, given the considerable distance across the Atlantic and uncertain maritime connections?

In a corrective exercise, we will therefore, where this is possible, also compare the art-historical/typological dating framework with the archaeological dates. A discussion like this, of a combined group of medieval artefacts, has not been undertaken before. Firstly, we will present the con-

Nyborg, Ebbe and Jette Arneborg. 2020. Christian Medieval Art in Norse Greenland: Crosses and Crucifixes and their European Antecedents.

Scripta Islandica 71: 155-176.

(C) Ebbe Nyborg and Jette Arneborg (CC BY)

DOI: $10.33063 /$ diva-429323 


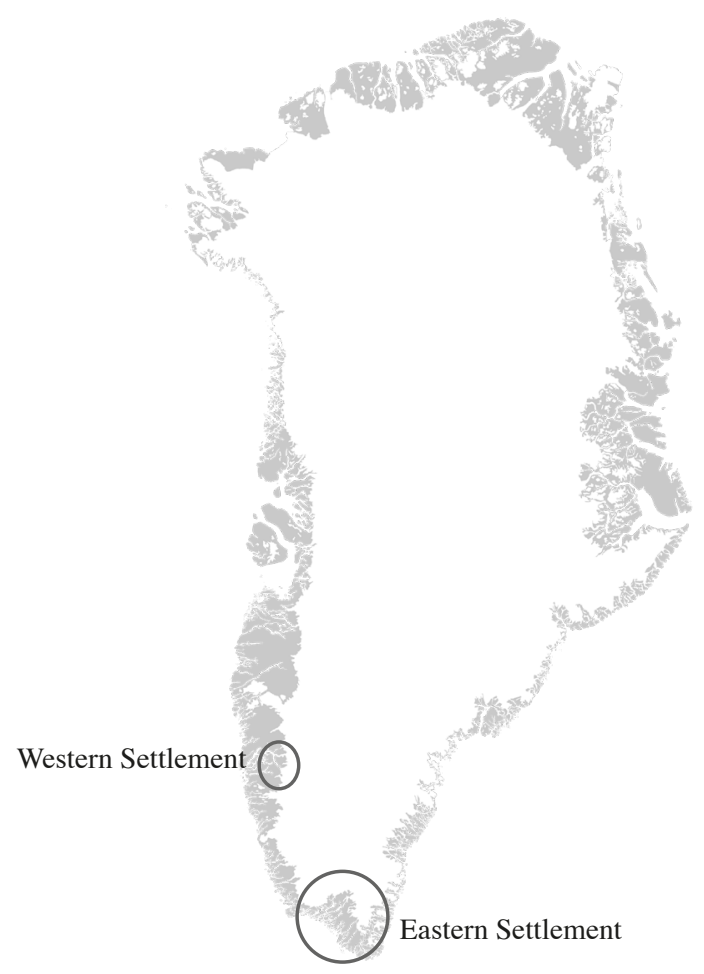

Fig. 1. The Norse settlements on the west coast of Greenland. Furthest to the south was the Eastern Settlement, whilst the Western Settlement was located near today's Nuuk. Base map from Nunniffiit, Greenland National Museum \& Archives' register over preserved ancient monuments.

text of the crosses and theories regarding their use, which will be followed by a description and analysis of the individual crosses and crucifixes.

\section{Churches, churchyards, and wooden crosses}

The Norse settlements in Greenland were established from Iceland at the end of the 900s and consisted of two settlements on the west coast of the enormous island (figure 1).

Accounts in the Icelandic sagas mention Leif Erikson and King Olaf 
Tryggvason of Norway as initiators of the introduction of Christianity in Greenland around the year 1000 (Magnusson \& Pálsson 1965: 86). However, archaeological investigations of the earliest churches suggest that the Icelandic colonists - or many of them - were already Christian when they came to Greenland, and that they erected quite small church buildings on their farms soon after settling (Arneborg 2012). The small churches were made of stone, turfs and driftwood, the only wood available, and had their closest counterparts in the homeland, Iceland. The Greenlandic bishop's seat at the farm Gardar (today's Igaliku), at the head of the Igaliku Fjord, was established around 1124. According to the account, Greenland's first bishop was appointed by Bishop Asser of Lund in Denmark, but with the establishment of the archiepiscopal see at Nidaros in Norway in 1152, Greenland was incorporated into the Norwegian ecclesiastical province, together with Iceland and the Faroe Islands, and as far as we know, all the bishops who were ordained at Gardar were Norwegians (Arneborg 1991). Written and archaeological evidence indicates that churches must have been erected at least 18 farms at the Norse settlements, and that at least six farms lost their churches during the 1200s. The churches associated with the first settlement of Greenland did not differ from the profane buildings. It is only the surrounding, circular churchyards that reveal the function of these buildings. Probably at the beginning of the 1100 s, and perhaps at the same time as Greenland's incorporation into the Norwegian ecclesiastical province and the establishment of the bishop's seat at Gardar, larger churches were introduced with Romanesque ground plans, consisting of a nave and narrower chancel (two-cell buildings), and from around 1250-1300, proper stone-built, nave churches (one-cell buildings) gained a foothold, following the development in Europe, especially in Norway. Nothing is known of the churches' furnishings, such as altars and images. The only archaeological finds associated with the functions of the churches are pieces of broken-up bells. The churchyards are especially interesting to us. In the earliest, the dead were lain side by side. Only in rare cases a grave has cut down into an earlier one, and this may indicate that the graves were marked above ground in some way, although we do not know how. In the later churchyards, in which graves can be very close together, a number of graves were marked by flat tombstones, which covered the whole grave, or by upright stones at the head and foot (for example, Nørlund \& Stenberger 1934: 39ff.). Such stone monuments, often with carved crosses, were also obviously associated with European types (figure 2). 


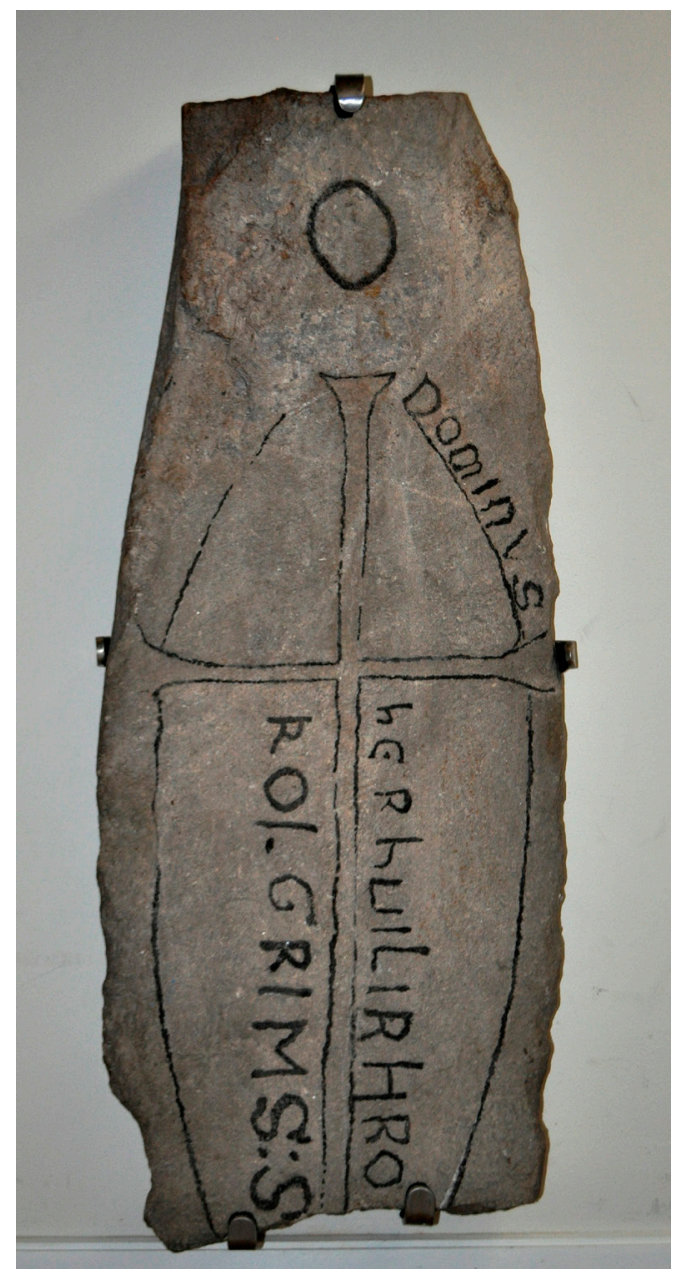

Fig. 2. Tombstone with cross found in the churchyard at Herjolfsnes (Ikigaat). The text reads "DOmInVS hER hUILIR HRO[AR] KOLGRIMS:S[ON]" - "Lord. Here rests Hróarr Kolgrimsson" (Imer 2017: 235). Submitted to the National Museum in Copenhagen in 1831. Photo: The National Museum of Denmark.

Some of the deceased were buried in wooden coffins, whilst others were just wrapped in cloths. Finds of textile remains in nearly all churchyards suggest that the latter was the most common. However, only in the churchyard at Herjolfsnes (Ikigaat), in the southernmost part of the Eastern Settlement, was the preservation so favourable that almost intact 
remains of clothing were preserved for posterity (Nørlund 1924; Østergård 2004). The church at Herjolfsnes was of the Romanesque type and in use until the settlement's depopulation in the middle of the 1400s. The church is by far the most significant finds location for the wooden crosses. No less than 58 crosses, varying in size between $69 \leftrightarrow 28.7 \mathrm{~cm}$ and 10.5 $\leftrightarrow 7.5 \mathrm{~cm}$, have been found here. Almost all of these are quite simple, with the cross arm joined at half wood onto the vertical stem of the cross and attached with a wooden rivet or inserted through a crack in the stem. Only three crosses did not have a peg.

\section{The function of the crosses}

Poul Nørlund, who was in charge of the archaeological investigations at Herjolfsnes in 1921, interpreted the crosses as "absolution crosses" made for the occasion and placed with the body to ensure the absolution of the deceased (Nørlund 1924: 64). He explained their pegs at the bottom as imitating the pegs on European processional crosses of metal, which were also used as altar crosses. He did not rule out the possibility that some of the large crosses might have functioned as processional or altar crosses before they were placed in the graves. He regarded the crosses as a chronological simplification and degeneration of the European crosses.

In a general examination of the Greenlandic crosses and their inscriptions in 1984, Marie Stoklund discussed whether the crosses initially could have been pushed down into the stony soil of the churchyard, and therefore have functioned as grave markers (Stoklund 1984: 104). This might explain the pegs at the bottom of their vertical stems but does not clarify the function and significance of the pegs - the crosses could have been pushed straight down into the ground at the churchyards without the tenon. Neither does this explain how a churchyard cross ended up being placed with its eventual owner, who had just been buried. Stoklund also ends up distancing herself to some extent from the theory. She instead suggests that the crosses were originally used in a "profane" context at the farms. She argues that there is no direct connection between the inscriptions and the dead (Stoklund 1984: 110ff.), and suggests, with reference to the excavations at Sandnes at the Western Settlement in 1932 (Roussell 1936), that crosses were actually also found in a non-ecclesiastical context. Stoklund therefore interpreted the crosses as devotional crosses 
or "hand crosses" from the homes, which were secondarily placed in the graves, perhaps with the owner of the cross when they died. Here, she supported her argument by referring to Norwegian archaeologist Aslak Liest $\varnothing 1$, who in 1980 published several similar wooden crosses recovered from archaeological excavations in Bergen. Many of the Bergen crosses also have a tenon for the purposes of attachment, and none are associated with churches or churchyards. Liestøl's interpretation was that the crosses served a function in daily life, and had been used to ward off evil and "placed upon something" at home (Liestøl 1980). The placing of the crosses in graves was therefore secondary, and in a similar way, the extraordinary crucifix group from Sandnes would have secondarily ended up in a grave after having originally been attached to something vertical (figure 10).

Poul Nørlund's view, that these are essentially burial crosses made for deposition with the bodies in connection with the burials, is solidly supported by the find circumstances at Herjolfsnes, whilst his explanation of the pegs can be debated. Stoklund's interpretation, on the other hand, assumes that these might originally have been either churchyard crosses or devotional crosses in homes, and thus presupposes an extensive and less probable secondary deposition of crosses in graves. It is undoubtedly clear from the circumstances of the finds that some of the crosses were used in a "secular" context at the farms. Two finely-made wooden crosses, for instance, were found in the living room at the Farm beneath the Sand at the Western Settlement (one shown in figure 9), and wooden crosses were also found in dwellings at the neighbouring farmstead Sandnes at Kilaarsarfik (Roussell 1936; Berglund 1998). The crosses that are found in a secular context can be explained by the very scattered distribution of churches at the Norse settlements, which meant that there was a long and difficult way to church, especially in winter. People went to church only rarely and needed devotional crosses at home, although this explanation cannot apply at Sandnes, where one of the Western Settlement's two churches was located. So, the crosses would to some extend have been used at the farmsteads and must have been made there. Regarding the more elaborate crosses and especially the crucifixes, which are examined below, we might imagine that these were in some way produced within the established church system, although this is peculiarly partly contradicted by a cross from the Farm beneath the Sand (figure 9) and a crucifix from Austmannadalen (figure 12), which were found at farm sites located far away from any churches. 


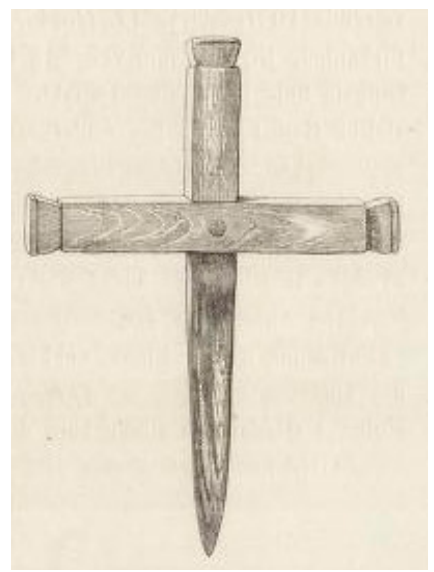

Fig. 3. Cross found in 1849 in the churchyard at Herjolfsnes, Ikigaat, farm $\varnothing 111$. Made from driftwood. Height $13 \mathrm{~cm}$. The National Museum of Denmark, Copenhagen, inventory number A92. Cross no. 152 in Nørlund's inventory (Nørlund 1924). After C.C. Rafn: Europæiske Oldsager fra America. Antiquarisk Tidsskrift. Copenhagen 1854.

\section{The four capital crosses}

The unimpressive cross A92 from Herjolfsnes (figure 3) has ends in the form of antiquising, Doric capitals, which consist of an inner, conical part, the echinus and an outer, rectangular abacus.

This type of cross, referred to here as a capital cross, can also have several inserted profiled parts. It is known from Anglo-Saxon book miniatures, such as the so-called Arenberg Passion (Raw 1990, Pl. II), and the well-known manuscript depiction dating to after 1031 of King Canute the Great and his Queen Ælfgyfu/Emma, who are seen donating an altar cross to the New Minster at Winchester (figure 4). A number of exquisite German capital crosses and crucifixes of gold with precious stones also date to the same time, the earliest of which is thought to be a magnificent piece known as the Lothar Cross and dating to c. 1000, in the treasury of Aachen Cathedral (figure 5) (Grimme 1973: 24-28).

There is obviously no direct connection between such exclusive crosses and Greenland. As a European phenomenon, the capital ends date to the 1000s. But they are also known slightly later in Scandinavia, where the golden crucifix from Lisbjerg in Denmark may be dated around 1100 (Nørlund 1926: 61-72, in which the Greenlandic crosses are also referred 


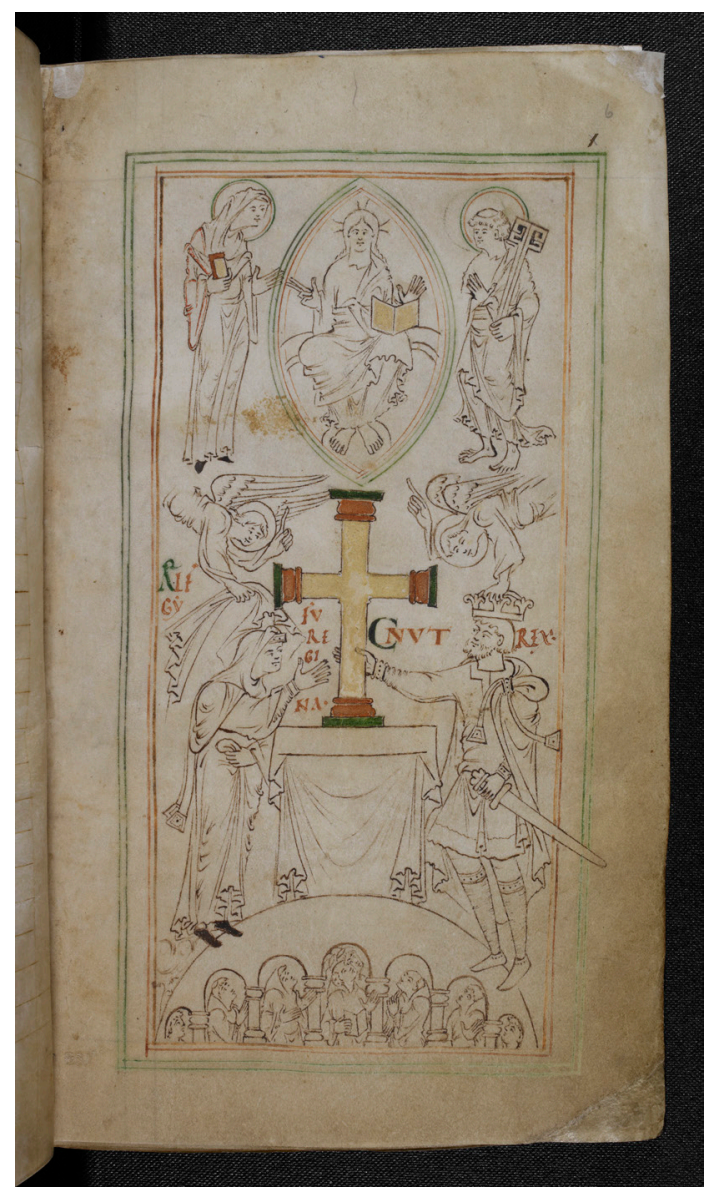

Fig. 4. King Canute the Great of Denmark and England, with his wife Ælfgyfu/ Emma, donating a cross to the altar in New Minster, Winchester. Miniature in its Liber Vitae, 1031. (C) British Library Board.

to). Capital ends are, however, primarily known from wooden sculpture in Norway. The earliest is probably a crucifix from Leikanger Church (figure 6 ), which is also dated to c. 1100 , and the latest example is perhaps the so-called "Ottonian" cross (figure 7), which the expert Martin Blindheim has dated to the second half of the 1100s (Blindheim 1998: 28-29,34). As it is a cross without a Christ figure, it can be directly visually compared with the Greenlandic examples, even though its capitals are slightly more complex in their profiles. 


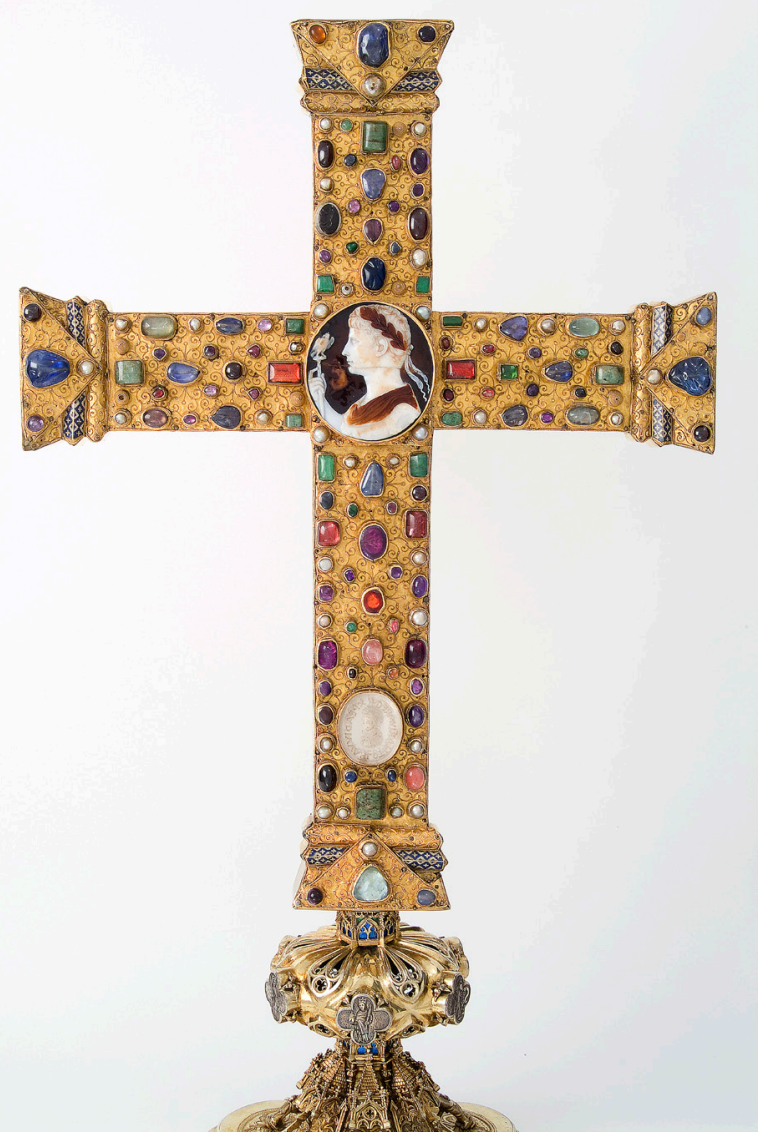

Fig. 5. The Lothar cross, c. 1000, of gold, precious stones and beads, with an antique cameo depicting Emperor Augustus. Height $50 \mathrm{~cm}$. In the treasure of Aachen Cathedral (C) Domkapitel Aachen, photo: Pit Siebigs.

Journeys to Greenland mostly started from Bergen in Norway (Magerøy 1993), and particularly after the Greenlandic bishop's seat came under the jurisdiction of Nidaros, it would seem likely that the cultural contacts would have been very one-sidedly Norwegian, and that the capital motif came from here. Given the obvious distribution in Norway, it would certainly be quite unlikely if a Greenlandic woodcarver had come up with the design independently.

Another Greenlandic cross from P. Nørlund's excavations at Herjolfsnes 


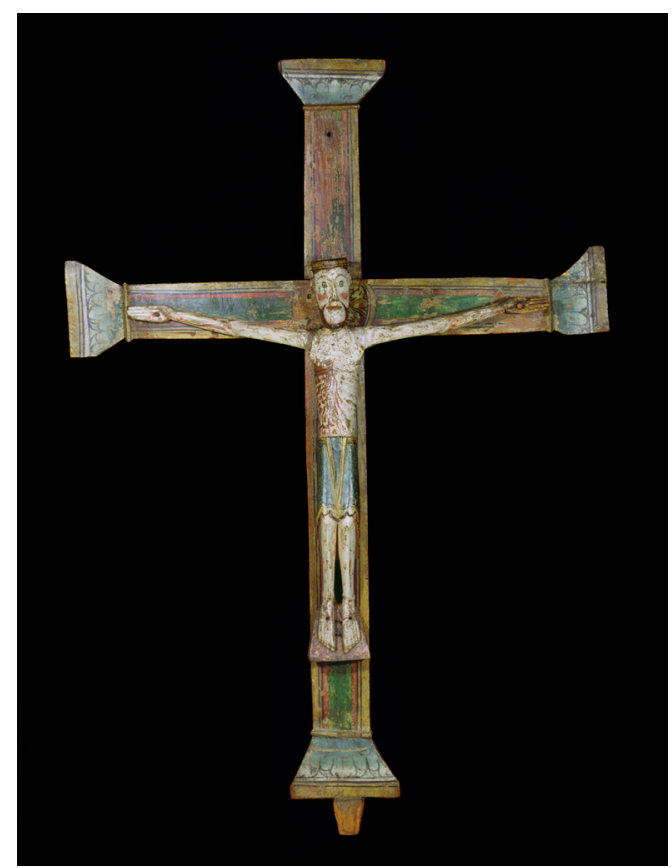

Fig. 6. Carved wooden crucifix of polychrome wood from Leikanger Church in Norway, c. 1100 . Height 149 cm. In Bergens Museum. Photo: Ann-Mari Olsen (C) Universitetsmuseet i Bergen (University Museum of Bergen).

in 1921 (figure 8), which is made of two crosses, has identical cross ends in the form of Doric capitals. It bears runic inscriptions, both on the vertical stem and the horizontal arm; one text is in Norse language and the other is apparently Latin. On the stem is the owner's name "Brakil" (Brigit?) and an invocation of Saint Michael and the Virgin Mary, whilst on the cross arm is a magical formula, which is upside down. According to runologists, the inscriptions can be attributed to two different rune carvers, but the stem and cross arm are only slightly different and are therefore probably parts of two very uniform crosses (Stoklund 1984: 110-111; Imer 2017: 226-227). The stem is smooth, with a profile inserted under the echinus, which has concave sides. The cross arm, on the other hand, has contoured lines along the edge, and the capitals are slightly larger, with a narrower profile. The similar character of the capitals suggests that the two original crosses may have been made by the same woodcarver. Their joining together can certainly be interpreted as a repair, using two strikingly uni- 


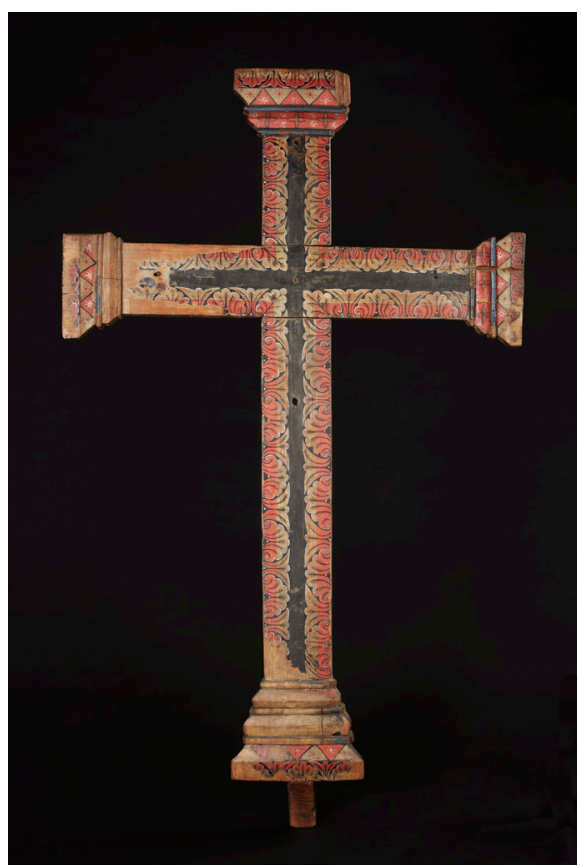

Fig. 7. The so-called Ottonian cross of polychromed wood, c. 1150-1200, from unknown Norwegian church. Height $146 \mathrm{~cm}$. In Universitetets Oldsaksamling, Oslo. Photo: Adnan Icagic (C) Universitetets Oldsaksamling, Oslo. Museum of Cultural History, Oslo (CC BY-SA).

form crosses. Lastly, there is a capital cross from the Farm beneath the Sand at the Western Settlement (figure 9). Its elongated capitals are a variation of those on the cross with the inscriptions, D10664 (figure 8), with a concave echinus, and the sides of the cross are unusually carved convex (Berglund 1998).

The two crosses from Herjolfsnes (A92 and D10664, figures 3 and 8) were both found in the churchyard. The first-mentioned cross, A92, is an unstratified stray find from 1849, whilst the cross with inscriptions, D10664, was found in the churchyard west of the church (Nørlund 1924; Jónsson 1924: 280ff.). The cross from the Farm beneath the Sand is interesting because of its "secular" context. It was found in 1993 during the excavation of the farmstead's living room (room 5), which dates to the 1300s. As the settlement was abandoned at the end of this century, the cross cannot be later in date.

It cannot be ruled out that an Anglo-Saxon cross or crucifix reached 


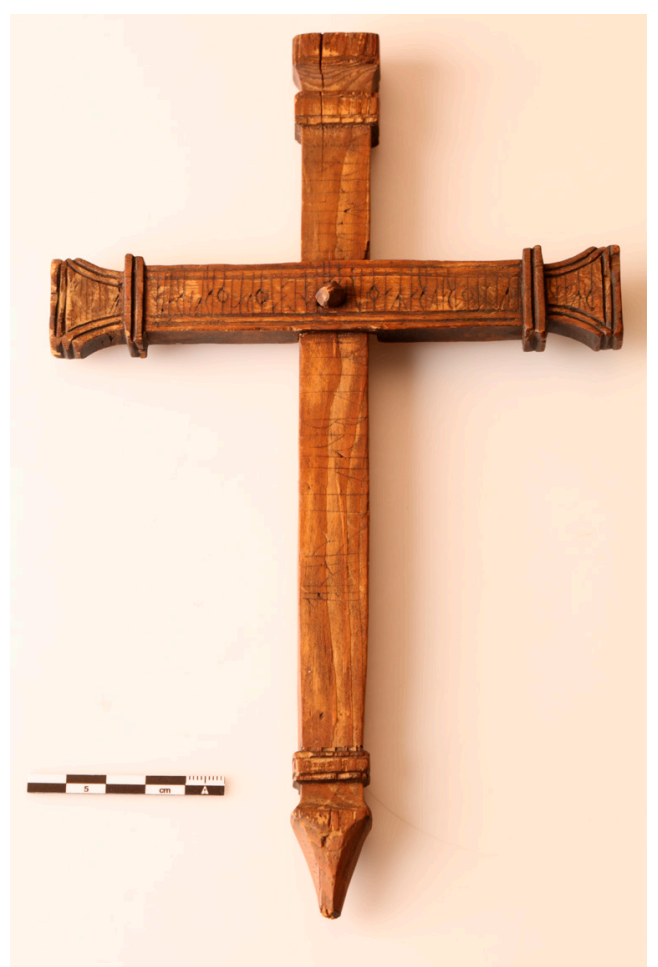

Fig. 8. Cross with inscription from Herjolfsnes. Made from driftwood. Height: $25 \mathrm{~cm}$. Inventory number D10664. The cross was transferred from the National Museum in Copenhagen to the Greenland National Museum \& Archives in Nuuk in 2001. Photo: Michael Nielsen, Greenland National Museum and Archives

Greenland directly from Great Britain and constituted this type, but all the evidence suggests that the four Greenlandic capital crosses can be attributed to cultural influence from Norway. The crosses can apparently be typologically traced right back to the first generations of settlement on Greenland. Bearing in mind the dating of the Norwegian objects and a possible additional delay in Greenland, a date within the 1100-1200s - and after the establishment of the Greenlandic diocese - might be estimated. The archaeological dating of the cross from the Farm beneath the Sand, on the other hand, is placed in the 1300s, with a possibility of a further long "lifespan". The Latin text on the cross with the inscriptions (D10664) also points in the same direction (Imer 2017: 228). This would indicate a dating to around 1300 or even later. 


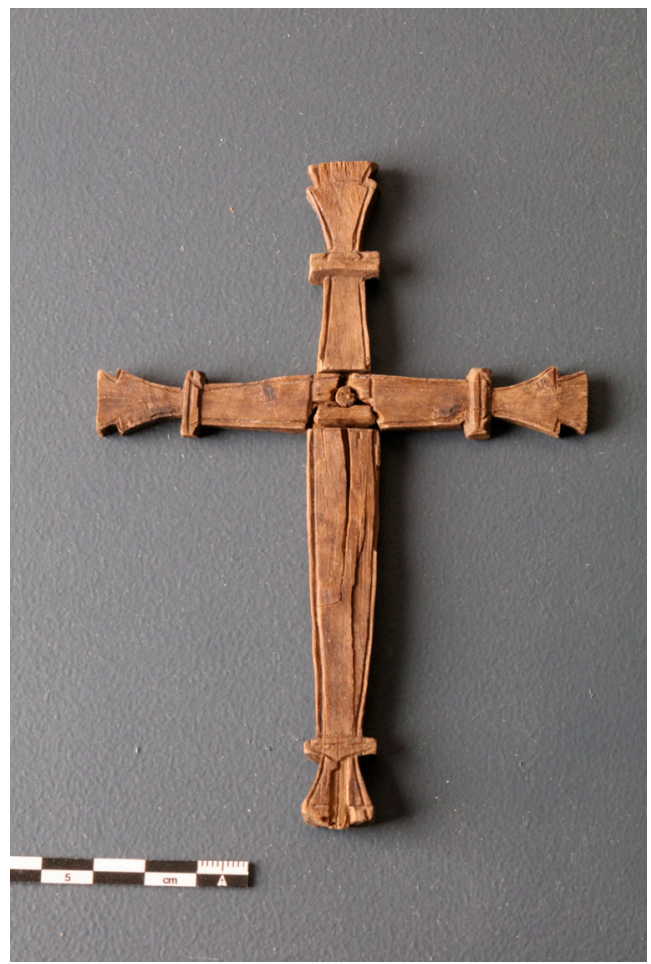

Fig. 9. Cross found at the Farm beneath the Sand, dating to the second half of the 1300s. Made from driftwood. Height: $14 \mathrm{~cm}$. Inventory number KNK1950x1208. Photo Michael Nielsen, Greenland National Museum \& Archives.

\section{The two crucifixions}

A remarkable crucifixion group from Sandnes at the Western Settlement is carved from quite thin spruce, measures $34.5 \leftrightarrow 13.3 \mathrm{~cm}(0.5-1.8 \mathrm{~cm}$ thick) and has originally been fastened onto something vertical with two holes (Roussell 1936: 171) (figure 10). This is therefore not a traditional churchyard cross.

The fine and detailed piece in openwork - unfortunately damaged in several places - is surrounded by foliage in an almond shape, which tapers slightly downwards. Jesus is hanging from the cross with slightly sloping arms and his head leaning to the right. He seems to be wearing a crown of thorns. The eyes are shut under frowned eyebrows, the ribs are 


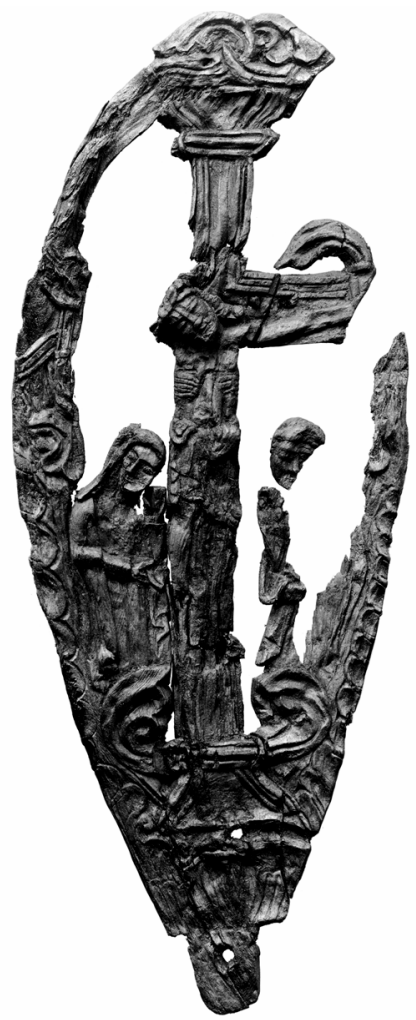

Fig. 10. Crucifix group (calvary) found in the churchyard at Sandnes in 1932. Made of spruce, Height: $34 \mathrm{~cm}$. Photo: The National Museum of Denmark.

marked, a turbulently folded loincloth has baggy overhangs at each hip. The position of the feet cannot be ascertained. The sides of the cross are contoured and the ends, certainly above and below, have a sort of leafed capital, from which large sprouts of acanthus emanate. At the bottom are flanking side figures, Mary and John the Apostle, who stand in traditional mourning poses. Mary is wearing a headcloth and leaning towards her son. Her right hand leads towards him and the left up to her cheek, like on a Norwegian crucifix group from the manor Austråt by Trondheim (Blindheim 2004: 56-57). Only small bits of John the Apostle are preserved. The naturalistic depiction of the persons, the hanging position and agonised expression of Jesus, as well as the penchant for acanthus leaves, point towards the transition between the two earliest phases of Gothic (Early and High Gothic), which in Europe occurred in the decades 


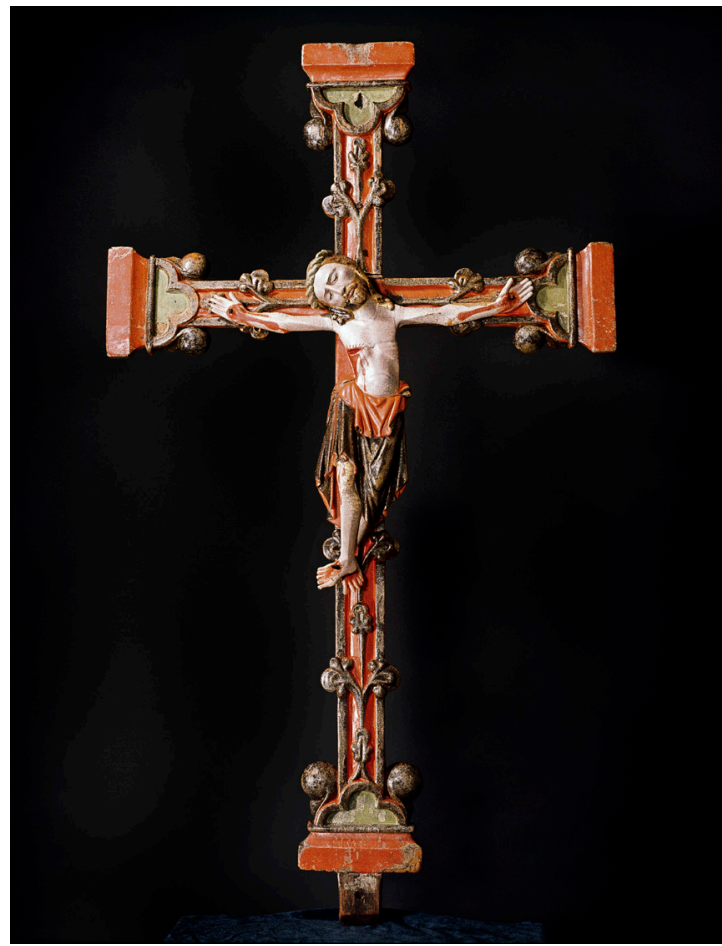

Fig. 11. Carved wooden polychromed crucifix from Tretten Church in Norway. C. 1275 . Height $171 \mathrm{~cm}$. In Universitetets Oldsaksamling, Oslo. Photo Håkan Lindberg (C) Universitetets Oldsaksamling, Oslo. Museum of Cultural History, Oslo (CC BY-SA).

around the middle of the 13th century. The crown of thorns, if present, became common in the 1230s in Europe, although not until after around c. 1250 in Scandinavia. Crucifix figures with small overhangs at the hips appear in a short period around 1250, and there are related crucifix figures in Musèe Schott in Brussels and in Kiaby Church, Scania (Didier 1982: 150-151; Liepe 1995: 30, 293). When we examine the details, the overall depiction seems to be mostly associated with a number of Norwegian crucifixes such as one from Tretten in eastern Norway from 1275-1300 (Blindheim 2004: 37-39, 190-91) (figure 11).

This work again seems to have depended on English book miniatures dating to around the middle of the 1200 s exemplified by the Amesbury Psalter. Here, we can identify basic characteristics that resemble those on the Greenlandic crucifix, although the figure from Tretten hangs with 


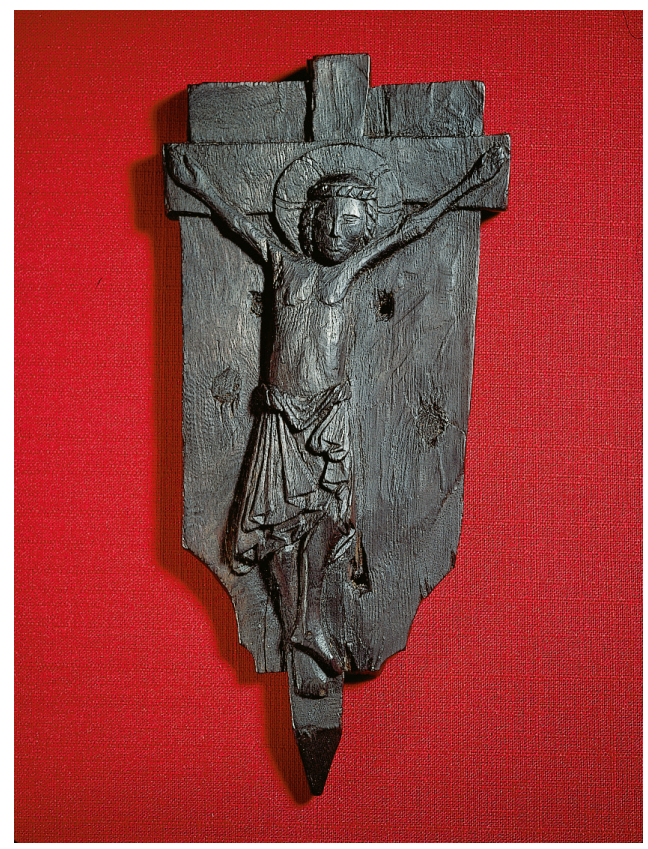

Fig. 12. Panel crucifix from Austmannadalen. Made from driftwood. Height: 21 $\mathrm{cm}$. In the National Museum, Copenhagen. Inventory number D12812. Photo: The National Museum of Denmark.

completely outstretched arms and its feet are turned outward in pain. The ends of the Norwegian crucifix are halved quatrefoils that terminate in a Doric capital, a trait which is not found on its own at this time. Halved quatrefoils combined with this type of capital is probably a specifically Nordic form, which is known from Denmark and is even more common in Norway (Blindheim 2004: 120, 130, 150 and 165). There are therefore once again reasons for us to assume that a Norwegian influence is present. The traits we have observed are so chronologically specific to the middle and second half of the 1200s, that we can perhaps imagine that the Greenlandic piece was made around 1300 . We can rule out that the object is an import.

Another Greenlandic crucifix that was found at farm V53d at the Western Settlement (Roussell 1941: 269), is in low relief on the background of a panel, from the ends of which the plain cross slightly protrudes (figure 12). This can be categorised as a panel crucifix. In the cross 
centre behind the head is a halo with curved incisions, which must indicate a cross. The figure is hanging low with completely straight arms, the head is upright, and its right foot is laid over the outstretched left with its side facing forwards. Under a narrow crown of thorns, long hair with diagonal incisions surrounds a summarily carved face with small eyes (open or closed?) and a straight nose and mouth. The nipples are slightly hanging, and the loincloth has a roll around the waist and a curved overhang at the front. It forms cornets on both sides with omega hems. As the figure, despite its low-hanging arms, appears upright, this is an almost Romanesque trait dating to before 1200, and the same applies to the marking of the nipples. The unusual position involving the side of a foot facing forwards can be traced back to French crucifixes dating to the beginning of the 1200s such as in Le Mans and Nevers (SchneiderBerrenberg 1977: 43-65). The figures of these are, however, depicted standing, with slightly separate feet. With other, slightly later figures that hang in the Gothic way, the position is maintained, although the right foot is placed on top of the left and the nail is struck though both feet like on the figures in St Katharinenthal, Switzerland, and at Brindisi, Italy (Schneider-Berrenberg 1977: fig.101, 113). It is this design that the crucifix from Austmannadalen is associated with. Nordic parallels consist of a Norwegian example from Skaun (Blindheim 1998: 80) and two Danish crucifixes in Rybjerg and Lomborg in North Jutland (Danmarks Kirker Ringkøbing Amt 2001-2010: 749-750). The early Gothic way of draping the loincloth is also characteristic of the mid-13th century and the crown of thorns (as a Nordic phenomenon) dates to after this. Another late trait is the way the figure hangs low, as can be seen in an illustration in Villard de Honnecourt's well-known sketchbook from c. 1230 (Scheller 1995: 176-187), but in Scandinavia dates to the 1300s. If the idea of using a panel for the background of the crucifix is not local to Greenland, it should be mentioned that crucifixes are also found in Europe where stems are expanded to form a side panel. The phenomenon is primarily Italian, although the examples found in the North include several Danish ones (Danmarks Kirker Ribe Amt 1988-91: 276-279; 1994-2003: 3013-15). Our crucifix is an unusually instructive example of stylistic delay within an isolated environment. It should obviously be dated from its latest traits and therefore most likely can be placed in the 1300s; the cultural influence is once again apparently Scandinavian, and probably Norwegian.

The two crucifixes from the Western Settlement can also only be loosely archaeologically dated. The group cannot be archaeologically dated 
at all, as it is an unstratified stray find from the churchyard at Sandnes (Kilaarsarfik). The panel crucifix was found in a "profane" context in a farm complex at the head of Austmannadalen (farm V53d). It was in the fill of a bench in a room dating to the farm's last phase of use, just before the settlement was abandoned at the end of the 1300s (Roussell 1941: 247). Its late dating therefore corresponds well with the art-historical evidence.

Apart from pieces of broken church bells, a crosier of walrus tusk, and a golden ring in a bishop's grave in the church yard of the cathedral no imported liturgical accessories have been found in the Norse Greenland. Even though situated far way from the church centres in Norway we might presuppose that at least the cathedral possessed a few holy crucifixes and processional crosses that inspired local artists and non-professional carvers, and styles may have wandered from farm to farm over long periods of time. Some of the carvers might never have seen the original pieces.

\section{Conclusion}

The attempt to challenge the art-historical/typological dates with the archaeological ones has only been partially successful. The crosses from Herjolfsnes and the crucifixion group from Sandnes were all found in churchyards without definite stratigraphic information. The cross from the Farm beneath the Sand is typologically dated to the 1100-1200s but was found in a dwelling room dating to the 1300s. It may already have been old at this point. But much would speak to the fact that the capital cross would have had its roots far back in time in Greenland. Lastly, the only chronological correspondence applies to the crucifix from Austmannadalen, whose art-historical dating to the 1300s is supported by its find location in a living room dating to just before the abandonment of the Western Settlement.

The Greenlandic crosses and crucifixes reflect a craft environment that was extremely locally based and not particularly specialised. The material, washed ashore wood and timbers, was however not just carved out of basic craftsmanship, but in the case of the crucifixions also with a certain degree of expertise and art. The delay in style testifies to an environment that was very isolated due to the considerable distance to Europe. It is, 
however, clear that quite specific impulses were received from across the Atlantic, and the mixture of stylistic traits, especially on the panel crucifix, demonstrate that the impulses could be "stored" over time, perhaps utilising models in the form of paintings and sculptures of different dates in the church interiors of the settlements. The crucifixes and images of saints in the churches may, like in Iceland, have been a mixture of imports and domestically made objects (Blindheim 1997). If in Greenland people had thus begun to produce their own images for the churches, local woodcarvers may have directly or indirectly contributed to the design of the small crosses and crucifixes. A further perhaps rather bold explanation might be that artistic Greenlanders were familiar with model illustrations, such as those in the Icelandic illustrated manuscript from the Late Middle Ages (Fett 1910; Scheller 1995: 241-249; Kristjánsdóttir 2013). Here, we find models or prototypes for Biblical scenes and saints in the "modern" stylistic designs of the 1400 s, mixed with long outdated forms dating to as far back as the High Middle Ages.

The investigation has cast new light upon a society that was the furthest outpost of the Christian world. The crosses and crucifixes that we have analysed represent the boundary for the influence of medieval art, and more than this. A further chronological and geographical dimension can be added. Important traits of the crosses and crucifixes were medieval inheritance from the classical, antique world: Traits, such as the Doric capital, the acanthus, and the naturalism in rendering of bodies and garment folds. The Norse settlements "at the end of the world" would thus represent the very earliest occurrence of antique art and culture in the Americas.

\section{Bibliography}

Arneborg, Jette, 1991: The Roman Church in Norse Greenland. The Norse of the North Atlantic. Acta Archaeologica 61 (1990). Pp. 142-150.

Arneborg, Jette, 2012: Churches, Christianity and magnate farms in the Norse Eastern Settlement. In: Gulløv, H.C., P.A. Toft \& C.P. Hansgaard (eds), Challenges and solutions. Northern Worlds - Report from workshop 2 at the National Museum, 1 November 2011. Pp. 167-170.

Barrett, James H., Sanne Boessenkool, Cathrine J. Kneale, Tamsin C. O’Connell and Bastiaan Star, 2019: Ecological globalisation, serial depletion and the medieval trade of walrus rostra. Quaternary Science Reviews 229 (2020). https://doi.org/10.1016/j.quascirev.2019.106122. 
Berglund, Joel, 1998: Christian symbols. In: Arneborg, J. \& H.C. Gulløv (eds), Man, Culture and Environment in Ancient Greenland. The Danish National Museum \& Danish Polar Center. Pp. 48-54.

Blindheim, Martin, 1997: Church and Art. In: L. Árnadóttir and K. Kiran (eds), The Medieval Church in Norway and Iceland. Norwegian Institute for Cultural Research and The National Museum of Iceland. Pp. 71-73.

Blindheim, Martin, 1998: Painted Wooden Sculpture in Norway c. 1100-1250, Oslo, Stockholm, Oxford, Boston.

Blindheim, Martin, 2004: Gothic Painted Wooden Sculpture in Norway 1220 1350. Oslo.

Danmarks Kirker, 1933ff., Ribe Amt 1988-91 and Ringkøbing Amt 2003-13, published by the National Museum, Copenhagen.

Didier, Robert, 1982: Christs et calvaires mosans du XIIIe siècle. In: Millènaire de la colègiale St. Jean de Liège. Exposition d'art et d'histoire. Liège, 17. Sept.-29. Octobre, Bruxelles. Pp. 141-172.

Fett, Harry, 1910: En islandsk tegnebog fra middelalderen. (Videnskabs-Selskabets Skrifter 2.) Christiania.

Frei, Karin M., Ashley N. Coutu, Konrad Smiarowski, Ramona Harrison, Christian Koch Madsen, Jette Arneborg, Robert Frei, Gardar Guðmundsson, Søren M. Sindbæk, James Woollett, Steven Hartman, Megan Hicks and Thomas H. McGovern, 2015: Was it for walrus? Viking Age settlement and medieval walrus ivory trade in Iceland and Greenland. World Archaeology. Pp. 1-28. http:// dx.doi.org/10.1080/00438243.2015.1025912.

Grimme, Ernst G., 1973: Der Aachener Domschatz. Achener Kunstblätter Band 42, Düsseldorf.

Imer, Lisbeth, 2017: Peasants and Prayers. The Inscriptions of Norse Greenland. Publications from the National Museum, vol. 25.

Jónsson, Finnur, 1924: Interpretation of the Runic Inscriptions from Herjolfsnæs. Meddelelser om Grønland vol. LXVII (1). Pp. 272-290.

Kristjánsdóttir, Guðbjörg, 2013: Íslenska teiknibókin / The Icelandic Model Book. Crymogea.

Liepe, Lena, 1995: Den medeltida träskulpturen i Skåne. En bilddokumentation. Lund.

Magnusson, Magnus and Hermann Pálsson, 1965: The Vinland Sagas. The Norse Discovery of America. Grænlendinga Saga and Eirik’s Saga. Penguin Books.

Magerøy, Hallvard, 1993: Soga om austmenn. Nordmenn som siglde til Island og Grønland i mellomalderen. Det Norske Videnskaps-Akademi. II. Hist.-Filos. Klasse Skrifter. Ny serie No. 9. Det Norske Samlaget. Oslo.

Nørlund, Poul, 1924: Buried Norsemen at Herjolfsnæs. Meddelelser om Grønland vol. LXVII (1). Pp. 1-270.

Nørlund, Poul, 1926: Gyldne Altre. Jysk Metalkunst fra Valdemarstiden. Copenhagen. (Second edition 1968.)

Nørlund, Poul and Martin Stenberger, 1934: Brattahlid. Meddelelser om Grønland, vol 88 (1). Copenhagen. 
Rafn, Carl C., 1854: Europæiske Oldsager fra America. Antiquarisk Tidsskrift. Copenhagen.

Raw, Barbara, 1990: Anglo-Saxon Crucifixion Iconography and the Art of the Monastic Revival. Cambridge, New York, Port Chester, Melbourne and Sidney. Roesdahl, Else, 1995: Hvalrostand, elfenben og nordboerne i Grønland. Odense. Roesdahl, Else, 1998: L'ivroire de morse et les norrises du Groenland. Proxima Thule. Revue d'ètudes nordiques Vol. 3. Pp. 9-48.

Roussell, Aage, 1936: Sandnes and the Neighbouring Farms. Meddelelser om Grønland, vol. 88 (2). Copenhagen.

Roussell, Aage, 1941: Farms and Churches in the Medieval Norse Settlements of Greenland. Meddelelser om Grønland, vol. 89 (1). Copenhagen.

Schneider Berrenberg, Rudiger, 1977: Monumental Kruzifixe im 13. Jahrhundert 1-2. München.

Scheller, Robert W., 1995: Exemplum. Model-Book Drawings and the Practice of Artistic Transmission in the Middle Ages (ca. 900-1470). Amsterdam.

Star Bastiaan, James H. Barrett, Agata T. Gondek and Sanne Boessenkool, 2018: Ancient DNA reveals the chronology of walros ivory trade from Norse Greenland. Tracing the medieval walrus ivory trade. Proceedings of the Royal Society B. Biological Sciences. https://doi.org/10.1098/rspb.2018.0978.

Stoklund, Marie, 1984: Nordbokorsene fra Grønland. Nationalmuseets Arbejdsmark. Pp. 101-113.

\section{Summary}

During a spectacular excavation in 1921 at the Norse farm of Herjolfsnes (Ikigaat) on the southern tip of Greenland, Poul Nørlund found 58 wooden crosses of driftwood in the graves at the site. These vary in size from c. 10 to $70 \mathrm{~cm}$. Since then, more crosses have been found in other churchyards, as well as a few in a more "profane" context in dwellings. Nearly all of these crosses are quite simple. But six of them are more elaborately carved with specific traits, which enable closer comparison with prototypes from Europe. Four crosses have Doric capital ends, which must be derived from the design of German and English crosses dating to the beginning of the 11th century and spread to Scandinavia in the 12th century. A regular crucifixion group (Calvary) has English and Norwegian antecedents dating to the mid-13th century, and a panel crucifix displays elements from a period as long c. 1200-1350, suggesting extreme lateness in style. There is nothing to stop us assuming that dissemination of influences essentially occurred through Norway and perhaps Iceland. Several stylistic traits, such as the Doric capitals, acanthus leaf and classical drapery, can be traced all the way back to classical antiquity and represent their earliest occurrence in the western hemisphere. 
Keywords: Norse Greenland, Herjolfsnes, wooden crosses, absolution crosses, devotional crosses, crucifixes, burials

Ebbe Nyborg

National Museum of Denmark

Middle Ages, Renaissance and Numismatics

Frederiksholms Kanal 12

DK-1220 Copenhagen

www.natmus.dk

ORCID iD 0000-0003-3546-5310

Jette Arneborg

National Museum of Denmark

Middle Ages, Renaissance and Numismatics

Frederiksholms Kanal 12

DK-1220 Copenhagen

www.natmus.dk

ORCID iD 0000-0003-2195-3727 


\title{
Recension
}

Triin Laidoner: Ancestor Worship and the Elite in Late Iron Age Scandinavia. A Grave Matter. London \& New York: Routledge 2020. 184 sidor. ISBN 978-0-367-00063-9

I monografin Ancestor Worship and the Elite in Late Iron Age Scandinavia. A Grave Matter, som är publicerad på det välrenommerade förlaget Routledge, argumenterar religionshistorikern Triin Laidoner från University of Aberdeen för att det fanns en allmän anfäderskult $i$ det förkristna Norden. Den kulten var stundtals offentlig och förknippades då med så kallade "superior ancestors" ('överordnade förfäder'), det vill säga anfäder till kunga- och furstefamiljer, som exempelvis de svensknorska Ynglingarna eller Háleygja-ätten från Nordnorge. Laidoner ställer sig kritisk till de forskare som tidigare tolkat dem som gudomliga och fört dem samman med den komparativa kategorin det sakrala kungadömet. De gestalter som i genealogier hyllas som kungaättens anfäder och som efter sin död erhöll offer vid sina gravhögar hade aldrig gudomlig status, utan betraktades av de troende som mänskliga anfäder. Laidoner är också kritisk till de forskare som hävdar att den euhemerism som kan iakttas i de medeltida källorna, där "gudar" som till exempel Freyr uppträder med mänskliga egenskaper, uteslutande ska ses som kristen polemik mot hedendomen. Dessa mänskliga egenskaper fanns där redan under förkristen tid, menar Laidoner, eftersom nordborna betraktade dem som förfäder och dödliga människor.

Studien är indelad i två delar, Part 1 "Theoretical consideration" och Part 2 "Case studies". Part 1 omfattar fyra kapitel. I introduktionskapitlet diskuteras metod, begrepp och källor. Här finns också ett kapitel om den

\author{
Sundqvist, Olof. 2020. Rec. av Triin Laidoner. Ancestor Worship \\ and the Elite in Late Iron Age Scandinavia. A Grave Matter. \\ Scripta Islandica 71: 177-183. \\ (C) Olof Sundqvist (CC BY) \\ DOI: 10.33063 /diva-429325
}


tidigare forskningen kring anfäderskult, dels den som förekommit i den allmänna kultur- och religionsforskningen, men också den som rör det fornnordiska sammanhanget. I ett kapitel diskuteras det komparativa begreppet "ancestor worship", som vanligtvis beskrivs som "the beliefs and ritual practices concerned with deceased predecessors" (s. 48). Kritiker har hävdat att man ofta lagt alltför stor vikt på "tro" i dessa definitioner och inte tagit upp aspekter som rör "kommunikation", "dyrkan" och "kult". Termen har kritiserats för att vara alltför generisk och att den leder till statiska tolkningar. I verkligheten varierar föreställningar om och praktiker i anslutning till de döda i olika kulturella kontexter. Trots kritiken tillämpar Laidoner termen "ancestor worship" och definierar den som det fenomen där relationen mellan levande och döda stundtals tar formen av offentlig kult (s. 50). I kapitel 3 presenterar Laidoner även det viktiga begreppet "superior ancestor worship", som ibland även benämns "royal ancestor worship" och som finns som en kategori vid sidan av begreppet anfäderskult inom den moderna socialantropologin. Den typen av anfädersdyrkan fanns bland bantu-talande folk i Sydafrika, till exempel, och också hos romarna, genom de så kallade lares praestites. "Superior ancestors" förekommer främst i patrilinjära klansamhällen, och utgörs av anfäder till den härskande familjen. I motsats till den vanliga anfäderskulten, som är relaterad till familjen och som utförs i hemmet, dyrkas "superior ancestors" av hela samhället vid offentliga kultplatser och gravar. Samtidigt ger de den ledande familjen legitimitet. Dessa överordnade anfäder är mäktigare än vanliga familjers anfäder. Representanter från den ledande familjen ska också leda kulten till dem vid helgedomen. Dessa anfäder betraktas inte som gudar, även om de har gudomliga drag. De är således inte kosmiska, allsmäktiga eller abstrakta som vanliga gudar (s. 60). De anses däremot ha existerat som mänskliga kungar i en ursprungstid. Släktskapsförbindelsen till anfäderna är artificiellt konstruerad och uttrycks ofta genom genealogier. Dessa genealogier är uppbyggda kring ätten, och syftar till att skydda den ledande familjens auktoritet och privilegier. Denna typ av anfäderskult är således politiskt orienterad. Grundläggande för dess ideologi är härstamning från en specifik anfader, det vill säga en gestalt som en gång levt på jorden, dött och sedan erhållit kult vid sin grav eller helgedom.

Den socialantropologiska kategorin "superior ancestor worship" kan enligt Laidoner tillämpas som ett teoretiskt ramverk även i det fornnordiska sammanhanget och då i synnerhet $\mathrm{i}$ den historiska analysen av källor som handlar om kungamakt, genealogier och kult. I den tidigare 
forskningen har kategorierna sakralt kungadöme och euhemerism dominerat som förklaringsmodeller då dessa teman diskuterats. Man har ofta ansett att de fornnordiska genealogiernas anfäder ytterst utgjordes av gudomar, till exempel Óðinn eller Freyr. Då dessa anfäder uppträder med mänskliga egenskaper i källorna har man hävdat att det är resultatet av en medeltida euhemerism, skapad av kristna författare som en polemisk metod att förringa de gamla gudarna och radera ut deras gudomliga status. Dessa forskningsparadigm behandlas utförligt i kapitel 4, "Kings and gods in Old Norse Religion". Laidoner är kritisk till båda dessa tolkningar och hävdar att den socialantropologiska modellen "superior ancestor worship" fungerar som ett bättre teoretiskt ramverk än de tidigare teorierna i analysen av dessa källor.

Part 2 omfattar sex kapitel med fyra "case studies", samt en introduktion till dem där den sociala och politiska kontexten presenteras. Denna del inkluderar även en allmän konklusion ("General conclusion") som rör hela studien. Fallstudierna är begränsade till namngivna anfäder, som erhållit kult ofta vid sina gravplatser. Ett kapitel tar upp kung Erik i Birka, som omtalas i Rimberts Vita Anskarii (ca 870). Ett annat kapitel behandlar den svensk-norska kungafamiljen Ynglingarna. I det kapitlet diskuteras tre anfäder, Freyr, Hálfdan svarti och Óláfr Geirstaðaálfr. Kapitlet om Háleygja-ätten har ett särskilt fokus på Porgerðr hǫlgabrúðr, som dyrkades särskilt i Hálogaland i Nordnorge. Det sista kapitlet behandlar bosättarna i Breiðafjorðr på västra Island. Den undersökningen har avgränsats till en landnámsmaðr, Pórólfr Mostrarskegg, och den kristna aristokratiska frun och kolonisatören Auðr djúp(a)úðga. Enligt Laidoner bekräftar traditionerna kring dessa namngivna gestalter förekomsten av en "superior ancestor worship" i det vikingatida Norden.

De tio kapitlen är rent allmänt elegant sammansatta, med en smidig prosa, och en tydlig argumentationslinje. Det teoretiska ramverket med "superior ancestor worship" hämtat från den moderna socialantropologin är innovativt och bidrar med insiktsfulla teoretiska resonemang och analytiska perspektiv. Laidoner har grundligt satt sig in i en omfattande korpus av vetenskaplig litteratur. Avhandlingens struktur med nio självständiga bibliografier leder emellertid till vissa störande upprepningar av allmän information som även bromsar studiens progression. En enkel bibliografi som täcker samtliga delar skulle ha föredragits framför det fragmenterade intryck de nio individuella bibliografierna nu ger.

Avhandlingens resultat är till stora delar rimligt, även om Laidoner i vissa fallstudier pressar källmaterialet för att få det att stämma med 
den hypotes som drivs i studien (se vidare nedan). Laidoner kunde ha övervägt att se teorin om "superior ancestor worship" mer som ett komplement till de tidigare analytiska modellerna som tillämpats i anslutning till föreliggande källmaterial, det vill säga "det sakrala kungadömet", "religious ruler ideology" och "euhemerism". Nu tycks hon mena att teorin om "superior ancestor worship" och dess tillämpning på det fornnordiska materialet exkluderar värdet av de andra teorierna i den historiska analysen av dessa källor.

Laidoners distinktion mellan kategorierna "superior ancestors" och "gudar" tycks i huvudsak bygga på att man uppfattat anfäder som mänskliga varelser som en gång har vandrat på jorden och först efter sin död har erhållet kult. Begreppet "gudar" är däremot vanligtvis associerat med övernaturliga och mytiska varelser:

... the concept of 'god' is usually associated with the supernatural, and the Old Norse gods, too, are more often than not viewed as having had mythic and divine dimensions in the Norsemen's religious cognition, despite early Scandinavia's regional kinship-based social structures. It is habitually overlooked that the concept of 'divine' is in essence alien to typical folk religions such as those in pagan Scandinavia, the 'gods' of whom were usually found in the history, experiences and customs of humans, not in transcendent, remote or mythical divinities (s. 15).

Laidoner menar således att de forskare som tillämpar teorier om "det sakrala kungadömet" och "euhemerism" stundtals har tolkat vissa namngivna varelser i de latinska och fornvästnordiska källorna som gudomar fastän de egentligen saknar den karaktäristiska som kategorin "god" förutsätter, det vill säga transcendens, kosmiska drag, allsmäktighet och abstraktion. Dessa varelser bör snarare med sina mänskliga drag betraktas som "superior ancestors". Med stöd av dessa kategorier och definitioner hävdar Laidoner att inte bara Erik i Birka, Hálfdan svarti, Óláfr Geirstaðaálfr, Pórólfr Mostrarskegg och Auðr djúp(a)úðga, utan att också Freyr och Porgerðr hǫlgabrúðr ska betraktas som "superior ancestors". Freyr, till exempel, var ursprungligen en mänsklig kung som först efter sin död fick rollen som en överordnad anfader och då kom att dyrkas med offer (s. 111-118, 125-126). Som stöd för denna slutsats hänvisar hon till skildringen av Freyr i Ynglinga saga kapitel 10 (ca 1230), som anger att då guden dog lades han i en gravhög i Uppsala. För att upprätthålla den goda årsväxten och freden (ár ok friðr) gav svearna gåvor till honom i högen. En liknande berättelse finns också bevarad i Óláfs saga Tryggvasonar (Flateyjarbók 1, s. 400-404) (ca 1390). Enligt min mening är det rimligare 
att se dessa skildringar som ett resultat av medeltida euhemerism. Snorre och andra medeltida författare var tvungna att beskriva de gamla gudarna som forntida kungar för att inte stöta sig med kyrkan och den kristna tron. Denna euhemerism förekommer inte heller i de äldre källor som behandlar Freyr. Det finns, till exempel, inget i Ynglingatal (ca 890) som talar för att Freyr betraktades som en dödlig anfader, lik till exempel Fjolnir, Sveigðir eller Vanlandi vars dödssätt, och i det sistnämnda fallet gravplats, beskrivs. Namnet Freyr förekommer i Ynglingatals kenningar där Alrekr and Eiríkr kallas Freys afspringr 'Freyrs avkomma' och Aðils Freys áttungr 'Freys ättling'. Andra kenningar antyder att kungaätten ansågs ha ett gudomligt ursprung. Kenningen týs áttungr, som betecknar Egill, ska i enlighet med Adolf Noreen och Elias Wessén troligen tolkas som 'gudens ättling' (syftande på Freyr) och inte som Laidoner hävdar 'Týrs ättling'. Det finns inget i andra källor som tyder på att Týr ansågs vara anfader för Ynglingarna (Sundqvist 2016, s. 71-73). Dessutom kallas Ingjaldr för goðkynningr, 'av gudomlig härkomst', vilket talar för att kungens anfader betraktades som en gudom. Laidoners resonemang att det fornvästnordiska begreppet goð refererar till en mänsklig hövding, som först efter sin död blev betraktad som en goði är närmast halsbrytande. Som stöd för detta hänvisar hon återigen till en euhemeristisk skildring i Ynglinga saga (kap. 4), där Njorðr, Freyr och Óðinn kallas blótgoðar (se s. 77).

Freyr skiljer sig från de andra namngivna och kända "superior ancestors" i Ynglingaätten genom att hans namn förekommer i ortnamn. Dessa teofora namn utbreder sig från Jämtland i norr till Jylland i söder. Här finns visserligen en regional koncentration av Freyr-namn i Mälarområdet och runt Viken. Detta faktum stöder dock inte Laidoners långsökta idé att Freyrs familj (underförstått Ynglingarna) utvandrat från Viken för att bosätta sig i Uppsala under folkvandringstid (s. 108). Genom denna flytt skulle Freyr-namnen ha spritt sig över de två regionerna. Distribution av de teofora ortnamnen talar snarare för att Freyr var en populär gudom under järnåldern med kult spridd över stora delar av Norden, men att han var särskilt dyrkad i Mälarområdet och runt Viken.

Betydelsen av Freyrs namn och dess funktion har många paralleller bland gudanamn i andra religioner. De flesta forskare menar att namnet återgår på ett urnordiska *Frauiaz (bildat till den indoeuropeiska roten *pro- 'framåt, främst, före') som betyder 'den främste' (se t.ex. Vikstrand 2001, s. 55). Det mesta talar för att det är en sekundär namnbildning som utgått från ett appellativ. Detta appellativ är troligen ekvivalent 
med gotiskans frauja 'herre'. Troligtvis har detta ord varit en titel eller noa-benämning på gudomen, det vill säga ett tillåtet namn eller titel som använts i stället för ett taburerat gudanamn (jfr Vikstrand 2001, s. 55). Ett vanligt religionshistoriskt exempel på noa-namn har vi i Gamla testamentet, där den israelske gudens namn Jahve byts ut mot det hebreiska appellativet adonaj, som betyder just 'herre'. Det finns många exempel i religionshistorien där gudar har namn eller titlar som betyder just 'herren', till exempel den grekiske guden Adonis (som förövrigt har en semitisk bakgrund) (se Sundqvist 2014).

Det är något oklart huruvida Laidoner anser att också Óðinn och Pórr ska betraktas som "superior ancestors". Kulten till dem kan genom veckodagarnas namn och runinskriften från Nordendorf föras tillbaka till mellersta och yngre järnåldern på kontinenten. Tanken att även de ska betecknas som "superior ancestors" känns osannolik, eftersom de båda spelar en viktig roll i de bevarade fornvästnordiska myttraditionerna. Där uppträder Óðinn i den kosmogoniska myten om världens tillkomst (t.ex. Gylfaginning 6-7), medan både Óðinn och Pórr spelar en central roll i myten om världens undergång vid Ragnarök (t.ex. Gylfaginning 51). I religionsfenomenologiska framställningar brukar en sådan kosmisk funktion vara ett centralt kännetecken för identifikationen av en gudom (se Panikkar 2005, s. 2256). Även Freyr spelar en viktig roll i de eskatologiska traditionerna om Ragnarök, där han strider mot Surtr (t.ex. Gylfaginning 51). Eftersom Freyr har denna kosmiska funktion i myterna och dessutom förs samman med Óðinn och Pórr i ett slags kultisk triad i källorna (så t.ex. Adam av Bremen IV, 26), tyder det på att han av nordborna betraktades som likvärdig med dessa mytiska varelser och uppfattades som en gudom. De mänskliga drag som de tre gudarna stundtals har i myttraditionerna kan bero på att dessa berättelser har haft en episk funktion och litterär gestaltning som kräver personifikationer. Om vi hade haft hymner, böner eller andra religiösa narrativ bevarade kan andra gudsbilder ha gestaltats i relation till dem (se Nordberg 2004 [2003], s. 60-65). Enligt min mening får man också en bra förklaringsmodell av Porgerðr họlgabrúðr, om man som Anders Hultgård (2014) tolkar henne i ljuset av den komparativa kategorin "lokalgudom". Laidoners förslag att hon var en överordnad "anmoder" är mindre trolig.

Triin Laidoner bidrar hursomhelst med många nya insikter i sin studie till förståelsen av det religionshistoriska sammanhanget under vikingatiden $i$ Norden genom att tillämpa den socialantropologiska kategorin "superior ancestors". De narrativa traditioner som rör Erik i Birka, Hálfdan svarti, 
Óláfr Geirstaðaálfr, Pórólfr Mostrarskegg och Auðr djúp(a)úðga träder här fram i nytt ljus då författaren ställer in dem in den tolkningsramen. Triin Laidoner tillhör tillsammans med Sophie Bønding, John Luke Murphy och Simon Nygaard en ny generation religionshistoriker som alla visar upp en stor teoretisk medvetenhet i utforskningen av den fornnordiska religionen. Det är uppenbart att vi här kan iaktta en ny trend inom detta forskningsfält, där generella kulturvetenskapliga teorier får en allt större betydelse i de religionshistoriska analyserna.

\section{Litteratur}

Hultgård, Anders, 2014: "Kultplats och gudstro. Om framväxten av lokala gudomar på germanskt område". I Eva Nyman et al. (red.), Den heliga platsen . Handlingar från symposiet Den heliga platsen Härnösand 15-18 september 2011, s. 23-38. Sundsvall.

Nordberg, Andreas, 2004 [2003]: Krigarna i Odins sal: Dödsföreställningar och krigarkult i fornnordisk religion. Andra upplagan. Stockholm.

Panikkar, Raimundo, 2005: "Deity”. I Lindsay Jones (red.), The Encyclopedia of Religion, Vol 4, 2nd edition, s. 2252-2263. Detroit: Gale.

Sundqvist, Olof, 2014: "Frö - mer än en fruktbarhetsgud?" Saga och Sed (Kungl. Gustav Adolfs Akademiens Årsbok 2014), s. 43-68. Uppsala

Sundqvist, Olof, 2016: An Arena for Higher Powers. Ceremonial Buildings and Religious Strategies for Rulership in Late Iron Age Scandinavia. NuS 150. Leiden/Boston: Brill.

Vikstrand, Per, 2001: Gudarnas platser: Förkristna sakrala ortnamn i Mälarlandskapen. Acta Academiae regiae Gustavi Adolphi. LXXVII. Studier till en svensk ortnamnsatlas utgivna av Thorsten Andersson. 17. Uppsala.

Olof Sundqvist

professor i religionshistoria

Institutionen för etnologi, religionshistoria och genusvetenskap

Stockholms universitet

ORCID iD 0000-0002-4304-9782 



\title{
Berättelse om verksamheten under 2019
}

\author{
Agneta Ney \& Marco Bianchi
}

Isländska sällskapets styrelse hade under år 2019 följande sammansättning: ordförande: Agneta Ney vice ordförande: Veturliði Óskarsson (redaktör för Scripta Islandica) sekreterare: Marco Bianchi skattmästare: Jan Axelson $\dagger$ (fram till 17 november) vice sekreterare: Alexandra Petrulevich ledamöter: Phil Beier, Simon Karlin Björk, Jessica Holmlund, Tommy Kuusela, Lasse Mårtensson (redaktör för Scripta Islandica).

Vid årets utgång var 42 personer och institutioner ständiga medlemmar eller hedersmedlemmar i sällskapet. Antalet medlemmar/prenumeranter på sällskapets e-postlista uppgick till 116 personer. Scripta Islandica prenumererades av 42 personer och institutioner.

Den sjuttionde årgången av Scripta Islandica utkom som fulltextpublikation i Digitala vetenskapliga arkivet (DiVA) i slutet av 2019. Följande sakkunniggranskade uppsatser ingår i volymen: Anders Hultgård, Om Vafprúðnismál; Andras Mortensen, Færeyinga saga som historisk kilde: En vurdering af sagaens ophavssituation og politiske miljø; Guðmundur Ólafsson \& Lise Gjedss $\varnothing$ Bertelsen, Det henrettede par i dobbeltgravhøjene i Kópavogur syd for Reykjavík i Ísland; Hubert Seelow, Sjö plánetur í ljóðmælum: Ein isländisches Gedicht über die Planetenkinder. Mit einem Exkurs: Kritische Anmerkungen zur Laienastrologie und Laienphilologie; Matteo Tarsi, Instances of loanword/native word textual variation in the manuscript transmission of Egils saga Skallagrímssonar and Gísla saga Súrssonar. Årgången innehåller följande recensioner: Marianne Kalinke, rev. of Natalie M. Van Deusen. The Saga of the Sister Saints. The Legend of Martha and Mary Magdalen in Old Norse-Icelandic Translation; Olof Sundqvist, rec. av Anders Hultgård. Midgård brinner. Ragnarök $i$ religionshistorisk belysning. Vidare innehåller årgången minnesord över 
Elena Gurevich (1957-2018) författade av Ada Kan, Lars Lönnroth och Agneta Ney.

Torsdagen den 25 april firades 70-årsdagen av sällskapets instiftande den 26 april 1949 med en föreläsningskväll i Humanistiska teatern. Följande föredrag hölls: Lasse Mårtensson \& Veturliði Óskarsson: Om Scripta Islandica; Daniel Sävborg: Kunskapen om isländsk litteratur i medeltidens Sverige; Anders Hultgård: Om Vafprúdnismál; Fredrik Charpentier Ljungqvist: Klimatförändringar på Island från landnám till nutid. Avslutningsvis tackade ordföranden Agneta Ney sällskapets hedersledamot Lennart Elmevik för hans mångåriga insatser för Isländska sällskapet. Sällskapets årsmöte hölls den 16 maj med ett föredrag av styrelseledamoten fil. dr Tommy Kuusela (Institutet för språk och folkminnen) om sexuellt betvingande trolldom i fornnordisk religion. På höstmötet den 7 november gästades sällskapet av fil. dr Håkan Jansson (Högskolan väst) som föreläste över ämnet Att studera förändringar i modern isländska något om verktyg och resultat.

Uppsala den 12 maj 2020

Agneta Ney och Marco Bianchi 


\section{Tack till våra granskare under åren 2011-2020}

Scripta Islandica vill varmt tacka följande forskare för osjälviskt och tidskrävande arbete som gjorts för tidskriften under de senaste tio åren i form av peer review:

Aðalheiður Guðmundsdóttir, Agneta Ney, Alessia Bauer, Anders Hultgård, Andreas Nordberg, Anne Mette Hansen, Anne-Sofie Gräslund, Annette Lassen, Anthony Faulkes, Ármann Jakobsson, Ástráđur Eysteinsson, Baldur Sigurðsson, Barbro Klein, Bernt Øyvind Thorvaldsen, Bjørn Bandlien, Bo Gräslund, Britta Olrik Frederiksen, Britt-Mari Näsström, Daniel Sävborg, David Dunér, Edward Reingold, Einar Gunnar Pétursson, Eldar Heide, Elise Kleivane, Else Mundal, Erik Simensen, Fabrizio D. Raschellà, Fjodor Uspenskij, François Xavier Dillmann, Frog, Gauti Kristmannsson, Geraldine Barnes, Gísli Sigurðsson, Guðmundur Ólafsson, Guðrún Nordal, Guðvarður Már Gunnlaugsson, Gunnar Karlsson, Gunnlaugur Ingólfsson, Gylfi Gunnlaugsson, Hans Fix, Haraldur Bernharðsson, Haukur Porgeirsson, Heimir Pálsson, Helge Sandøy, Helgi Haraldsson, Helgi Skúli Kjartansson, Henrik Janson, Henrik Williams, Hermann Bengtsson, Hrefna Róbersdóttir, Håkan Rydving, Jon Gunnar Jørgensen, Jón P. Pór, Jonas Wellendorf, Jonatan Pettersson, Judith Jesch, Judy Quinn, Juhani Nuorluoto, Karl G. Johansson, Kristín Bjarnadóttir, Kristinn Jóhannesson, Lars Lönnroth, Lena Liepe, Lilja Árnadóttir, Magnus Källström, Marco Bianchi, Margaret Cormack, Marjolein Stern, Massimiliano Bampi, Maths Bertell, Mats Malm, Mats Thelander, Michael Lerche Nielsen, Mikael Males, Odd Einar Haugen, Olle Sundqvist, Orri Vésteinsson, Patrik Larsson, Paula Henrikson, Per Stille, Pernille Hermann, Regina Jucknies, Rolf Stavnem, Sabine Walther, Sebastian Cöllen, Sif Ríkharðsdóttir, Sigurður Konráðsson, Simonetta Battista, Stefan Brink, Stephen Mitchell, Svanhildur Óskarsdóttir, Svante 
Fischer, Svante Strandberg, Sveinn Yngvi Egilsson, Sverrir Jakobsson, Tarrin Wills, Theodore M. Anderson, Terry Gunnell, Porbjörg Helgadóttir, Tomas Lindqvist, Tommy Kuusela, Torfi Tulinius, Úlfar Bragason, Vésteinn Ólason, Viðar Pálsson, Pórdís Edda Jóhannsdóttir, Pórhallur Eypórsson, Pórunn Sigurðardóttir.

Redaktörerna 


\section{Författarna i denna årgång}

Brynja Porgeirsdóttir, Ph.D., Postdoctoral Research Associate, University of Cambridge, Department of Anglo-Saxon, Norse, and Celtic. ORCID iD 0000-0003-1474-5604.

Ebbe Nyborg, cand mag, Former editor of the inventory Danmarks Kirker at The National Museum Copenhagen, ORCID iD 0000-0003-35465310 .

Henrik Williams, professor, Uppsala universitet, Institutionen för nordiska språk, ORCID iD 0000-0003-1738-7072.

Jette Arneborg, Ph.D., Senior researcher, National Museum of Denmark, Middle Ages, Renaissance and Numismatics, ORCID iD 0000-00032195-3727.

Katarzyna Anna Kapitan, Ph.D., H.M. Queen Margrethe II Distinguished Research Fellow at the Vigdís Finnbogadóttir Institute of Foreign Languages, University of Iceland, National Museum of Iceland and Museum of National History, Frederiksborg Castle, Denmark. ORCID iD 0000-0003-2763-0056.

Lise Gjedss $\varnothing$ Bertelsen, Ph.D., senast verksam som Marie Curie Research Fellow vid Uppsala universitet, Institutionen för arkeologi och antik historia, ORCID iD 0000-0002-5719-5481.

Már Jónsson, professor, University of Iceland, Faculty of History and Philosophy, ORCID iD 0000-0003-4891-4154.

Olof Sundqvist, professor, Stockholms universitet, Institutionen för etnologi, religionshistoria och genusvetenskap, ORCID iD 0000-00024304-9782. 



\section{Scripta Islandica ISLÄNDSKA SÄLLSKAPETS ÅRSBOK}

ÅRGÅNG 1 · 1950: Einar Ól. Sveinsson, Njáls saga.

ÅRGÅNG 2 - 1951: Chr. Matras, Det færøske skriftsprog af 1846.-Gösta Franzén, Isländska studier i Förenta staterna.

ÅRGÅNG 3 - 1952: Jón Aðalsteinn Jónsson, Biskop Jón Arason.-Stefan Einarsson, Halldór Kiljan Laxness.

ÅRGÅNG 4 · 1953: Alexander Jóhannesson, Om det isländske sprog.-Anna Z. Osterman, En studie över landskapet i Voluspá.-Sven B. F. Jansson, Snorre. ÅRGÅNG 5 · 1954: Sigurður Nordal, Tid och kalvskinn.-Gun Nilsson, Den isländska litteraturen i stormaktstidens Sverige.

ÅRGÅNG 6 · 1955: Davíð Stefánsson, Prologus till »Den gyllene porten».— Jakob Benediktsson, Det islandske ordbogsarbejde ved Islands universitet.Rolf Nordenstreng,Volundarkviða v. 2.-Ivar Modéer, Över hed och sand till Bæjarstaðarskogur.

ÅRGÅNG 7 · 1956: Einar Ól. Sveinsson, Läs-och skrivkunnighet på Island under fristatstiden._Fr. le Sage de Fontenay, Jonas Hallgrimssons lyrik.

ÅRGÅNG 8 - 1917: Porgils Gjallandi (Jón Stefánsson), Hemlängtan._Gösta Holm, I fågelberg och valfjära. Glimtar från Färöarna.-Ivar Modéer, Ur det isländska allmogespråkets skattkammare.

ÅRGÅNG 9 · 1958: K.-H. Dahlstedt, Isländsk dialektgeografi. Några synpunkter.-Peter Hallberg, Kormáks saga.

ÅRGÅNG 10 · 1959: Ivar Modéer, Isländska sällskapet 1949-1959._Sigurður Nordal, The Historical Element in the Icelandic Family Sagas._Ivar Modéer, Johannes S. Kjarval.

ÅRGÅNG 11 · 1960: Sigurd Fries, Ivar Modéer 3.11.1904-31.1.1960.Steingrímur J. Porsteinsson, Matthías Jochumsson och Einar Benediktsson.Ingegerd Fries, Genom Ódáđahraun och Vonarskarð - färder under tusen år.

ÅRGÅNG 12 · 1961: Einar Ól. Sveinsson, Njáls saga.

ÅRGÅNG 13 - 1962: Halldór Halldórsson, Kring språkliga nybildningar i nutida isländska.-Karl-Hampus Dahlstedt, Gudruns sorg. Stilstudier över ett eddamotiv.-Tor Hultman, Rec. av Jacobsen, M. A.-Matras, Chr., Föroyskdonsk orðabók. Færøsk-dansk ordbog.

ÅRGÅNG 14 - 1963: Peter Hallberg, Laxness som dramatiker.-Roland Otterbjörk, Moderna isländska förnamn.-Einar Ól. Sveinsson, Från Mýrdalur.

ÅRGÅNG 15 · 1964: Lars Lönnroth, Tesen om de två kulturerna. Kritiska studier i den isländska sagaskrivningens sociala förutsättningar._Valter Jansson, Bortgångna hedersledamöter.

ÅRGÅNG 16 · 1965: Tryggve Sköld, Isländska väderstreck. 
ÅRGÅNG 17 - 1966: Gun Widmark, Om nordisk replikkonst i och utanför den isländska sagan.-Bo Almqvist, Den fulaste foten. Folkligt och litterärt i en Snorri-anekdot.

ÅRGÅNG 18 · 1967: Ole Widding, Jónsbóks to ikke-interpolerede håndskrifter. Et bidrag til den isländske lovbogs historie.-Steingrimur J. Porsteinsson, Jóhann Sigurjónsson och Fjalla-Eyvindur.

ÅRGÅNG 19 - 1968: Einar Ól. Sveinsson, Eyrbyggja sagas kilder.-Svávar Sigmundsson, Ortnamnsforskning på Island.-Lennart Elmevik, Glömskans häger. Till tolkningen av en Hávamálstrof.-Berättelsen om Audun, översatt av Björn Collinder.

ÅRGÅNG 20 - 1969: Sveinn Höskuldsson, Skaldekongressen på Parnassen - en isländsk studentpjäs._Evert Salberger, Cesurer i Atlakviða.

ÅRGÅNG 21 · 1970: Davíð Erlingsson, Etiken i Hrafnkels saga Freysgoða._Bo Almqvist, Isländska ordspråk och talesätt.

ÅRGÅNG 22 · 1971: Valter Jansson, Jöran Sahlgren. Minnesord.-Lennart Elmevik, Ett eddaställe och några svenska dialektord.-Bjarne Beckman, Hur gammal är Hervararsagans svenska kungakrönika?-Baldur Jónsson, Några anmärkningar till Blöndals ordbok. - Evert Salberger, Vel glýioð eller velglýioð. En textdetalj i Vǫluspá 35.-Anna Mörner, Isafjord.

ÅRGÅNG 23 · 1972: Bo Ralph, Jon Hreggviðsson-en sagagestalt i en modern isländsk roman.-Staffan Hellberg, Slaget vid Nesjar och »Sven jarl Håkonsson».-Thorsten Carlsson, Norrön legendforskning-en kort presentation.

ÅRGÅNG 24 · 1973: Peter Hallberg, Njáls saga-en medeltida moralitet?Evert Salberger, Elfaraskáld - ett tillnamn i Njáls saga._Richard L. Harris, The Deaths of Grettir and Grendel: A New Parallel.-Peter A. Jorgensen, Grendel, Grettir, and Two Skaldic Stanzas.

ÅRGÅNG 25 · 1974: Valter Jansson, Isländska sällskapet 25 år.-Ove Moberg, Bröderna Weibull och den isländska traditionen._Evert Salberger, Heill pú farir! Ett textproblem i Vafprúđnismál 4._Bjarne Beckman, Mysing._Hreinn Steingrímsson, »Að kveða rímur».-Lennart Elmevik, Två eddaställen och en västnordisk ordgrupp.

ÅRGÅNG 26 · 1975: Björn Hagström, Att särskilja anonyma skrivare. Några synpunkter på ett paleografiskt-ortografiskt problem i medeltida isländska handskrifter, särskilt Isländska Homilieboken._Gustaf Lindblad, Den rätta läsningen av Isländska Homilieboken.-Bo Ralph, En dikt av Steinpórr, islänning._Kristinn Jóhannesson, Från Värmland till Borgarfjörður. Om Gustaf Frödings diktning i isländsk tolkning.

ÅRGÅNG 27 · 1976: Alan J. Berger, Old Law, New Law, and Hœnsa-Póris saga.-Heimir Pálsson, En översättares funderingar. Kring en opublicerad översättning av Sven Delblancs Åminne.-Kunishiro Sugawara, A Report on Japanese Translations of Old Icelandic Literature.-Evert Salberger, Ask Burlefot. En romanhjältes namn._Lennart Elmevik, Fisl. giogurr. 
ÅRGÅNG 28 · 1977: Gustaf Lindblad, Centrala eddaproblem i 1970-talets forskningsläge. - Bo Ralph, Ett ställe i Skáldskaparmál 18.

ÅRGÅNG 29 · 1978: John Lindow, Old Icelandic páttr: Early Usage and Semantic History._Finn Hansen, Naturbeskrivende indslag i Gísla saga Súrssonar._Karl Axel Holmberg, Uppsala-Eddan i utgåva.

ÅRGÅNG 30 · 1979: Valter Jansson, Dag Strömbäck. Minnesord.-Finn Hansen, Benbrud og bane i blåt.-Andrea van Arkel, Scribes and Statistics. An evaluation of the statistical methods used to determine the number of scribes of the Stockholm Homily Book._Eva Rode, Svar på artiklen »Scribes and Statistics».-Börje Westlund, Skrivare och statistik. Ett genmäle.

ÅRGÅNG 31 · 1980: Björn Högström, Fvn. bakkakolfr och skotbakki. Några glimtar från redigeringen av en norrön ordbok.-Alan J. Berger, The Sagas of Harald Fairhair.-IIkka Hirvonen, Om bruket av slutartikel i de äldsta norröna homilieböckerna IsIH och GNH.-Sigurgeir Steingrimsson, Tusen och en dag. En sagosamlings vandring från Orienten till Island._Jan Terje Faarlund, Subject and nominative in Oid Norse.-Lars-Erik Edlund, Askraka-ett engångsord i Egilssagan.

ÅRGÅNG $32 \cdot$ 1981: Staffan Hellberg, Kungarna i Sigvats diktning. Till studiet av skaldedikternas språk och stil._Finn Hansen, Hrafnkels saga: del og helhed.Ingegerd Fries, Njals saga 700 år senare.

ÅRGÅNG 33 - 1982: Jan Paul Strid, Veiðar námo-ett omdiskuterat ställe i Hymiskviða._Madeleine G. Randquist, Om den (text)syntaktiska och semantiska strukturen i tre välkända isländska sagor. En skiss.-Sigurgeir Steingrímsson, Árni Magnusson och hans handskriftsamling.

ÅRGÅNG 34 · 1983: Peter Hallberg, Sturlunga saga - en isländsk tidsspegel.— Porleifur Hauksson, Anteckningar om Hallgrímur Pétursson.-Inger Larsson, Hrafnkels saga Freysgoða. En bibliografi.

ÅRGÅNG 35 · 1984: Lennart Elmevik, Einar Ólafur Sveinsson. Minnesord.Alfred Jakobsen, Noen merknader til Gísls páttr Illugasonar.-Karl-Hampus Dahlstedt, Bygden under Vatnajökull. En minnesvärd resa till Island 1954.Michael Barnes, Norn.-Barbro Söderberg, Till tolkningen av några dunkla passager i Lokasenna.

ÅRGÅNG 36 · 1985: Staffan Hellberg, Nesjavísur än en gång.-George S. Tate, Eldorado and the Garden in Laxness' Paradisarheimt.- Porleifur Hauksson, Vildvittror och Mattisrövare i isländsk dräkt. Ett kåseri kring en översättning av Ronja rövardotter.-Michael Barnes, A note on Faroese $/ \theta />/ \mathrm{h} /$. -Björn Hagström, En färöisk-svensk ordbok. Rec. av Ebba Lindberg \& Birgitta Hylin, Färöord. Liten färöisk-svensk ordbok med kortfattad grammatik jämte upplysningar om språkets historiska bakgrund.-Claes Åneman, Rec. av Bjarne Fidjest $\varnothing 1$, Det norrøne fyrstediktet.

ÅRGÅNG 37 - 1986: Alfred Jakobsen, Om forfatteren av Sturlu saga.-Michael $P$. Barnes, Subject, Nominative and Oblique Case in Faroese.-Marianne E. Kalinke, The Misogamous Maiden Kings of Icelandic Romance.-Carl-Otto 
von Sydow, Jon Helgasons dikt I Árnasafni. Den isländska texten med svensk översättning och kort kommentar.

ÅRGÅNG 38 · 1987: Michael P. Barnes, Some Remarks on Subordinate Clause Word-order in Faroese._Jan Ragnar Hagland, Njáls saga i 1970-og 1980-åra. Eit översyn över nyare forskning.-Per-Axel Wiktorsson, Om Torleiftåten.Karl-Hampus Dahlstedt, Davío Stefánssons dikt Konan, sem kyndir ofninn minn. Den isländska texten med svensk översättning och kort kommentar.

ÅRGÅNG 39 - 1988: Alfred Jakobsen, Snorre og geografien.-Joan TurvillePetre, A Tree Dream in Old Icelandic.-Agneta Breisch, Fredlöshetsbegreppet i saga och samhälle._Tommy Danielsson, Magnús berfættrs sista strid._Ola Larsmo, Att tala i röret. En orättvis betraktelse av modern isländsk skönlitteratur. ÅRGÅNG 40 - 1989: Alv Kragerud, Helgdiktningen og reinkarnasjonen._Jan Nilsson, Guðmundr Ólafsson och hans Lexicon Islandicum — några kommentarer. ÅRGÅNG 41 · 1990: Jan Ragnar Hagland, Slaget på Pezinavellir i nordisk og bysantinsk tradisjon. - William Sayers, An Irish Descriptive Topos in Laxdœla Saga.-Carl-Otto von Sydow, Nyisländsk skönlitteratur i svensk översättning. En förteckning. Del 1.-Karl Axel Holmberg, Rec. av Else Nordahl, Reykjavík from the Archaeological Point of View.

ÅRGÅNG 42 · 1991: Stefan Brink, Den norröna bosättningen på Grönland. En kortfattad forskningsöversikt jämte några nya forskningsbidrag.-Carl-Otto von Sydow, Två dikter av Jón Helgason i original och svensk dräkt med kommentar.Carl-Otto von Sydow, Nyisländsk skönlitteratur i svensk översättning. En förteckning. Del 2._Nils Österholm, Torleiftåten i handskriften Add 4867 fol._ Lennart Elmevik, Rec. av Esbjörn Rosenblad, Island i saga och nutid.

ÅRGÅNG 43 - 1992: Anne Lidén, St Olav in the Beatus Initial of the Carrow Psalter-Michael P. Barnes, Faroese Syntax-Achievements, Goals and Problems.-Carl-Otto von Sydow, Nyisländsk skönlitteratur i svensk översättning. En förteckning. Del 3.

ÅRGÅNG 44 · 1993: Karl Axel Holmberg, Isländsk språkvård nu och förr. Med en sidoblick på svenskan._Páll Valsson, Islands älsklingsson sedd i ett nytt ljus. Några problem omkring den nya textkritiska utgåvan av Jónas Hallgrímssons samlade verk: Ritverk Jónasar Hallgrímssonar I-IV, 1989._William Sayers, Spiritual Navigation in the Western Sea: Sturlunga saga and Adomnán's Hinba.Carl-Otto von Sydow, Nyisländsk skönlitteratur i svensk översättning. En förteckning. Del 4.

ÅRGÅNG 45 · 1994: Kristín Bragadóttir, Skalden och redaktören Jón Porkelsson.-Ingegerd Fries, När skrevs sagan? Om datering av isländska sagor, särskilt Heiðarvígasagan.-Sigurður A. Magnússon, Sigurbjörn Einarsson som student i Uppsala på 1930-talet. Översättning, noter och efterskrift av Carl-Otto von Sydow.

ÅRGÅNG 46 - 1995: Ingegerd Fries, Biskop Gissur Einarsson och reformationen._François-Xavier Dillmann, Runorna i den fornisländska litteraturen. En översikt.-William Sayers, Poetry and Social Agency in Egils saga SkallaGrímssonar. 
ÅRGÅNG 47 · 1996: Lennart Elmevik, Valter Jansson. Minnesord._Jón Hnefill Aðalsteinsson, Blot i forna skrifter.-Gísli Pálsson, Språk, text och identitet i det isländska samhället.

ÅRGÅNG 48 · 1997: Lennart Elmevik, Anna Larsson. Minnesord.-Lennart Moberg, "Stóð und árhjalmi”. Kring Hákonarmál 3:8.-Henric Bagerius, Vita vikingar och svarta sköldmör. Föreställningar om sexualitet i Snorre Sturlassons kungasagor.-Páll Valsson, En runologs uppgång och fall.-Björn Hagström, Något om färöisk lyrik - mest om Christian Matras.

ÅRGÅNG 49 · 1998: Veturliði Óskarsson, Om låneord og fremmed påvirkning på ældre islandsk sprog.-Jóhanna Barðdal, Argument Structure, Syntactic Structure and Morphological Case of the Impersonal Construction in the History of Scandinavian.-_Jan Ragnar Hagland, Note on Two Runic Inscriptions relating to the Christianization of Norway and Sweden._-William Sayers, The ship heiti in Snorri's Skáldskaparmál.- Henrik Williams, Rec. av Snorres Edda. Översättning från isländskan och inledning av Karl G. Johansson och Mats Malm.

ÅRGÅNG 50 - 1999: Lennart Elmevik, Isländska sällskapet 50 år.-Bjarni Guðnason, Guðrún Ósvifursdóttir och Laxdæla Saga.-Veturliði Óskarsson, Verbet isländskt ské.-Henrik Williams, Nordisk paleografisk debatt i svenskt perspektiv. En kort överblick._Carl-Otto von Sydow, Jón Helgasons dikt Kom milda nótt i svensk tolkning. - Veturliði Óskarsson, Är isländsk språkvård på rätt väg?-Gun Widmark, Isländsk-svenska kontakter i äldre tid.

ÅRGÅNG 51 · 2000: Lennart Elmevik, Vidar Reinhammar. Minnesord.-Peter Springborg, De islandske håndskrifter og "håndskriftsagen".-Gun Widmark, Om muntlighet och skriftlighet i den isländska sagan._Judy Quinn, Editing the Edda-the case of Vôluspá.-Kirsten Wolf, Laughter in Old Norse-Icelandic Literature.-Fjodor Uspenskij, Towards Further Interpretation of the Primordial Cow Auðhumla._Tom Markey, Icelandic sími and Soul Contracting._Björn Hagström, Den färöiska "Modersmålsordboken".

ÅRGÅNG 52 · 2001: Lennart Elmevik, Claes Åneman. Minnesord.-Lars Lönnroth, Laxness och isländsk sagatradition._François-Xavier Dillmann, Om hundar och hedningar. Kring den fornvästnordiska sammansättningen hundheiðinn.- Mindy MacLeod, Bandrúnir in Icelandic Sagas.-Thorgunn Sncedal, Snorre Sturlasson-hövding och historiker.-Guðrún Kvaran, Omkring en doktorafhandling om middelnedertyske låneord i islandsk diplomsprog frem til år 1500 .

ÅRGÅNG 53 - 2002: Veturliði Óskarsson, Studiosus antiqvitatum. Om Jón Ólafsson från Grunnavík, förebilden till Halldór Laxness sagoperson Jón Guðmundsson från Grindavik.-Pórgunnur Sncedal, From Rök to Skagafjörður: Icelandic runes and their connection with the Scandinavian runes of the Viking period._Patrik Larsson, Det fornvästnordiska personbinamnet Kikr._Veturliði Óskarsson, Ur en eddadikts forskningshistoria.

ÅRGÅNG 54 · 2003: Henrik Williams, Än lever de gamla gudarna. Vikten av att forska om fornisländska.-Anna Helga Hannesdóttir, Islänningars attityder till språkliga normer.-Kristinn Jóhannesson, Halldór Laxness-samtidens 
spegel._Fredrik Charpentier Ljungqvist, Arngrímur Jónsson och hans verk.Adolfo Zavaroni, Communitarian Regime and Individual Power: Othinus versus Ollerus and Mithothyn.

ÅRGÅNG 55 · 2004: Heimir Pálsson, Några kapitel ur en oskriven bok.Staffan Fridell, At ósi skal á stemma. Ett ordspråk i Snorres Edda.-Agneta Ney, Mö-traditionen i fornnordisk myt och verklighet._Martin Ringmar, Vägen via svenska. Om G. G. Hagalíns översättning av en finsk ödemarksroman.Svante Norr, A New Look at King Hákon's Old Helmet, the árhjálmr._Lasse Mårtensson, Två utgåvor av Jóns saga helga. En recension samt några reflexioner om utgivningen av nordiska medeltidstexter.

ÅRGÅNG 56 - 2005: Lennart Elmevik, Lennart Moberg. Minnesord._Fredrik Charpentier Ljungqvist, The Significance of Remote Resource Regions for Norse Greenland. - Andreas Nordberg, Handlar Grimnesmål 42 om en sakral måltid? Daniel Sävborg, Kormáks saga - en norrön kärlekssaga på vers och prosa.Ingvar Svanberg och Sigurður Agisson, The Black Guillemot (Cepphus grylle) in Northern European Folk Ornithology.-Staffan Fridell, At ósi skal á stemma. Ett ordspråk i Snorres Edda. 2._Else Mundal, Literacy - kva talar vi eigentleg om? - Leidulf Melve, Literacy - eit omgrep til bry eller eit brysamt omgrep?

ÅRGÅNG 57 - 2006: Theodore M. Andersson, Víga-Glúms saga and the Birth of Saga Writing._Staffan Fridell, Fvn. hrynja och fsv. rynia. Om ett eddaställe och en flock i Södermannalagen.-Kirsten Wolf, The Color Blue in Old NorseIcelandic Literature._Fredrik Charpentier Ljungqvist, Kristen kungaideologi i Sverris saga._Lars Lönnroth, Sverrir's Dreams.-Arnved Nedkvitne, Skriftkultur i skandinavisk middelalder-metoder og resultater.-Lars Lönnroth, The Growth of the Sagas. Rec. av Theodore M. Andersson, The Growth of the Medieval Icelandic Sagas (1180-1280).-Anders Hultgård, rec. av François-Xavier Dillmann, Les magiciens dans l'Islande ancienne. Études

sur la représentation de la magie islandaise et de ses agents dans les sources littéraires norroises.-Heimir Pálsson, Den stora isländska litteraturhistorian. Rec. av Íslensk bókmenntasaga I-V. Red. Vésteinn Ólason, Halldór Guðmundsson \& Guðmundur Andri Thorsson. Sigurd Fries, Jón Aðalsteinn Jónsson och studiet av nyisländskan i Sverige.

ÅRGÅNG 58 - 2007: Heinrich Beck, Die Uppsala-Edda und Snorri Sturlusons Konstruktion einer skandinavischen Vorzeit.-Gunnhild Røthe, Porgerðr Hölgabrúðr - the fylgja of the Háleygjar family.-Michael Schulte, Memory culture in the Viking Ages. The runic evidence of formulaic patterns. - Lennart Elmevik, Yggdrasill. En etymologisk studie.-Henrik Williams, Projektet Originalversionen av Snorre Sturlassons Edda? Studier i Codex Upsaliensis. Ett forskningsprogram.-Sverre Bagge, "Gang leader" eller "The Lord's anointed" i Sverris saga? Svar til Fredrik Ljungqvist og Lars Lönnroth._Heimir Pálsson, Tungviktare i litteraturhistorien. En krönika.

ÅRGÅNG 59 · 2008: Marianne Kalinke, Clári saga. A case of Low German infiltration. - Ármann Jakobsson, En plats i en ny värld. Bilden av riddarsamhället i Morkinskinna.-Margaret Cormack, Catholic saints in Lutheran legend. Post- 
reformation ecclesiastical folklore in Iceland.-Tommy Danielsson, Social eller existentiell oro? Fostbrödradråp i två isländska sagor.-Mathias Strandberg, On the etymology of compounded Old Icelandic Óðinn names with the second component -foðr.-Susanne Haugen, Bautasteinn-fallos? Kring en tolkning av ett fornvästnordiskt ord.-Lasse Mårtensson och Heimir Pálsson, Anmärkningsvärda suspensioner i DG 11 4to (Codex Upsaliensis av Snorra Edda) - spåren av en skriven förlaga? - Stefan Olsson, Harald hos jätten Dovre. Forntida initiationssymbolik i en medeltida tåt.-Bo-A. Wendt, Eddan och texttermerna. Kort terminologiskt genmäle till Henrik Williams.-Michael Schulte, Literacy in the looking glass. Vedic and skaldic verse and the two modes of oral transmission.-Svanhildur Óskarsdóttir, rec. av Skaldic Poetry of the Scandinavian Middle Ages, volume VII: Poetry on Christian Subjects 1-2, ed. Margaret Clunies Ross.-Else Mundal, rec. av Reflections on Old Norse Myths, red. Pernille Hermann, Jens Peter Schjødt och Rasmus Tranum Kristensen._Pernille Hermann, rec. av Learning and Understanding in the Old Norse World. Essays in Honour of Margaret Clunies Ross, ed. Judy Quinn, Kate Heslop och Tarrin Wills. ÅRGÅNG 60 - 2009: Daniel Sävborg, Scripta Islandica 60.-Svanhildur Óskarsdóttir, To the letter. Philology as a core component of Old Norse studies. John McKinnell, Ynglingatal. A minimalist interpretation.-Lars Lönnroth, Old Norse text as performance.-Elena Gurevich, From accusation to narration. The transformation of senna in Íslendinga pættir.-Theodore M. Andersson, The formation of the Kings' sagas._-Helgi Skúli Kjartansson, Law recital according to Old Icelandic law. Written evidence of oral transmission? - Terry Gunnell, Ansgar's conversion of Iceland.-Helen F. Leslie, Border crossings. Landscape and the Other World in the Fornaldarsögur.-Tsukusu Itó, The Gosforth fishingstone and Hymiskviða. An example of inter-communicability between the Old English and Old Norse speakers.

ÅRGÅNG 61 · 2010: Helga Kress, Eine bewusste Antiregel. Die Stimme der Frau in Halldór Laxness Gedichten.-Margrét Eggertsdóttir, Hallgrímur Pétursson and Tormod Torfæus. Their scholarly friendship._Jan Ragnar Hagland, Hefi ek mark á máli mart. Litt om vokabular for særdrag ved folks språk og uttale i gammal-islandsk. - Olof Sundqvist, Om hängningen, de nio nätterna och den dyrköpta kunskapen i Hávamál 138-145. Stefanie Gropper, rec. av Jonatan Pettersson, Fri översättning i det medeltida Västnorden._Jonatan Pettersson, rec. av Alexanders saga, Manuscripta Nordica 2, utg. Andrea de Leeuw van Weenen.Lennart Elmevik, In memoriam. Oskar Bandle, Peter Foote, Björn Hagström. ÅRGÅNG 62 · 2011: Ingvil Brügger Budal, Who is "I"? Translation of riddarasögur as a collective performance.-Finnur Friðriksson, Modern Icelandic: Stable or in a state of flux?-Svante Janson, The Icelandic calendar. Susanne Haugen, anm. av Kormaks saga. Historik och översättning av Ingegerd Fries._Heimir Pálsson, rec. av Úlfar Bragason, Ætt og saga: Um frásagnarfræði Sturlungu eða Íslendinga sögu hinnar miklu._Helgi Skúli Kjartansson, rec. av Rikke Malmros, Vikingernes syn på militær og samfund: Belyst gennem skjaldenes fyrstedigtning._Lasse Mårtensson, rec. av Vår eldste bok. Skrift, 
miljø og biletbruk i den norske homilieboka. Bibliotheca Nordica 3, red. Odd Einar Haugen och Åslaug Ommundsen.-Rune Palm, rec. av. Poetry from the Kings' Sagas 2. From c. 1035-1300 (Skaldic Poetry of the Scandinavian Middle Ages II), ed. Kari Ellen Gade._Úlfar Bragason, rec. av Margaret Clunies Ross, The Cambridge Introduction to the Old Norse-Icelandic Saga.

ÅRGÅNG 63 - 2012: Silvia Hufnagel, Icelandic society and subscribers to Rafn's Fornaldar sögur nordrlanda-Guðrún Kvaran, Nucleus latinitatis og biskop Jón Árnasons orddannelse-Heimir Pálsson, Om källor och källbehandling i Snorris Edda. Tankar kring berättelser om skapelsen-Triin Laidoner, The Flying Noaidi of the North: Sámi Tradition Reflected in the Figure Loki Laufeyjarson in Old Norse Mythology-Lars Wollin, Kringla heimsins-Jordennes krets-Orbis terrarum. The translation of Snorri Sturluson's work in Caroline SwedenPorleifur Hauksson, Implicit ideology and the king's image in Sverris sagaOlof Sundqvist, rec. av Annette Lassen, Odin på kristent pergament. En teksthistorisk studie-Kirsten Wolf, rec. av Rómverja saga, ed. Porbjörg Helgadóttir ÅRGÅNG 64 · 2013: Lennart Elmevik, Sigurd Fries. Minnesord-Daniel Sävborg, Rune Palm. Minnesord-Ulla Börestam, Gun Widmark. Minnesord-Agneta Ney, Bland ormar och drakar. En jämförande studie av Ramsundsristningen och Gökstenen-Judy Quinn, Death and the king: GrottasQngr in its eddic contextBrittany Schorn, Divine Semantics. Terminology for the Human and the Divine in Old Norse Poetry-Kirsten Wolf, Body Language in Medieval Iceland. A Study of Gesticulation in the Sagas and Tales of Icelanders-Terry Gunnell, rec. av Merrill Kaplan, Thou Fearful Guest. Addressing the Past in Four Tales in Flateyjarbók-Bernt $\emptyset$. Thorvaldsen, rec. av Lars Lönnroth, The Academy of Odin. Selected Papers on Old Norse Literature-Vésteinn Ólason, rec. av The Poetic Edda. Vol. III. Mythological Poems II, ed. Ursula Dronke-Lars Wollin, rec. av Sif Rikhardsdottir, Medieval Translations and Cultural Discourse. The Movement of Texts in England, France and Scandinavia-Margaret Clunies Ross, rec. av Snorri Sturluson The Uppsala Edda DG 11 4to, ed. Heimir Pálsson ÅRGÅNG 65 · 2014: Pórdís Edda Jóhannesdóttir \& Veturliði Óskarsson, The Manuscripts of Jómsvíkinga Saga: A Survey-Sirpa Aalto, Jómsvíkinga Saga as a Part of Old Norse Historiography-Leszek P. Stupecki, Comments on Sirpa Aalto's Paper-Alison Finlay, Jómsvíkinga Saga and Genre- Judith Jesch, Jómsvíkinga Sogur and Jómsvíkinga Drápur: Texts, Contexts and IntertextsDaniel Sävborg, Búi the Dragon: Some Intertexts of Jómsvíkinga Saga-Alison Finlay, Comments on Daniel Sävborg's Paper-Jakub Morawiec, Danish Kings and the Foundation of Jómsborg-Władystaw Duczko, Viking-Age Wolin (Wollin) in the Norse Context of the Southern Coast of the Baltic Sea-Michael Lerche Nielsen, Runic Inscriptions Reflecting Linguistic Contacts between WestSlav Lands and Southern Scandinavia-Henrik Williams, Comments on Michael Lerche Nielsen's Paper- Jürgen Udolph, On the Etymology of JómsborgAlexandra Petrulevich, Comments on Jürgen Udolph's Paper-Marie Novotná \& Jiři Starý, Rendering Old Norse Nouns and Names in Translation into WestSlavic Languages 
ÅRGÅNG 66 · 2015: Lise Gjedss $\phi$ Bertelsen, Sigurd Fafnersbane sagnet som fortalt på Ramsundsristningen-Anne-Sofie Gräslund, Kvinnorepresentationen på de senvikingatida runstenarna med utgångspunkt i Sigurdsristningarna-Terry Gunnell, Pantheon? What Pantheon? Concepts of a Family of Gods in PreChristian Scandinavian Religions-Tommy Kuusela, "Den som rider på Freyfaxi ska dö”. Freyfaxis död och rituell nedstörtning av hästar för stup - Lars Lönnroth, Sigurður Nordals brev till Nanna-Jan Alexander van Nahl, The Skilled Narrator. Myth and Scholarship in the Prose Edda-William Sayers, Generational Models for the Friendship of Egill and Arinbjorn (Egils saga Skallagrímssonar)-Olof Sundqvist, The Pre-Christian Cult of Dead Royalty in Old Norse Sources: Medieval Speculations or Ancient Traditions?-Lars Lönnroth, rec. av Minni and Muninn: Memory in Medieval Nordic Culture, red. Pernille Herrmann, Stephen A. Mitchell \& Agnes S. Arnórsdóttir-Olof Sundqvist, rec. av Mikael Males: Mytologi i skaldedikt, skaldedikt i prosa. En synkron analys av mytologiska referenser i medeltida norröna handskrifter-Per-Axel Wiktorsson, rec. av The Power of the Book. Medial Approaches to Medieval Nordic Legal Manuscripts, red. Lena Rohrbach-Kirsten Wolf, rev. of Lasse Mårtensson. Skrivaren och förlagan: Norm och normbrott i Codex Upsaliensis av Snorra Edda

ÅRGÅNG 67 · 2016: Aðalheiður Guðmundsdóttir, Tales of Generations: A comparison between some Icelandic and Geatish narrative motifs-Eldar Heide, The term leizla in Old Norse vision literature - contrasting imported and indigenous genres?-Heimir Pálsson, DG 3 in memoriam-Sveinn Yngvi Egilsson, Jónas Hallgrímssons inre och yttre natur-Úlfar Bragason, Jón Halldórsson of Stóruvellir and his reading circle: Readings in the farming community in Iceland around 1870-Judy Quinn, rev. of Eddukvæði, red. Jónas Kristjánsson \& Vésteinn Ólason-Daniel Sävborg, rec. av Riddarasogur: The Translation of European Court Culture in Medieval Scandinavia, utg. Karl G. Johansson och Else Mundal-Heimir Pálsson, rec. av Pórunn Sigurðardóttir. Heiður og huggun: Erfiljóð, harmljóð og huggunarkvæði á 17. öld-Veturliði Óskarsson, anm. av Jón Ólafsson úr Grunnavík: AEvisögur ypparlegra merkismanna, utg. Guðrún Ása Grímsdóttir

ÅRGÅNG 68 - 2017: Lars Erik Edlund, Ingegerd Fries (1921-2016): Minnesord-Aðalheiður Guðmundsdóttir, Some Heroic Motifs in Icelandic Art-Daniel Sävborg, Blot-Sven: En källundersökning-Declan Taggart, All the Mountains Shake: Seismic and Volcanic Imagery in the Old Norse Literature of Pórr-Elín Bára Magnúsdóttir, Forfatterintrusjon i Grettis saga og paralleller i Sturlas verker-Haukur Porgeirsson \& Teresa Dröfn Njarðvík, The Last Eddas on Vellum-Heimir Pálsson, Reflections on the Creation of Snorri Sturluson's Prose Edda-Magnus Källström, Monumenta lapidum aliquot runicorum: Om runstensbilagan i Verelius' Gothrici \& Rolfi Westrogothiae Regum Historia (1664) Matteo Tarsi, Creating a Norm for the Vernacular: Some Critical Notes on Icelandic and Italian in the Middle Ages-Olof Sundqvist, Blod och blot: Blodets betydelse och funktion vid fornskandinaviska offerriter-Sveinn Yngvi Egilsson, Kan man skriva pastoral poesi så nära Nordpolen? Arkadiska skildringar i is- 
ländska dikter från artonhundratalet-Tommy Kuusela, "Pá mælti Míms hǫfuð": Jätten Mimer som kunskapsförmedlare i fornnordisk tradition-Lars Lönnroth, rec. av A Handbook to Eddic Poetry: Myths and Legends of Early Scandinavia, red. Carolyne Larrington, Judy Quinn \& Brittany Schorn-Lars-Erik Edlund, rec. av Islänningasagorna. Samtliga släktsagor och fyrtionio tåtar. Red. Kristinn Jóhannesson, Gunnar D. Hansson \& Karl G. Johansson-Aðalheiður Guðmundsdóttir, rev. of Agneta Ney. Bland ormar och drakar: Hjältemyt och manligt ideal $i$ berättartraditioner om Sigurd Fafnesbane

ÅRGÅNG 69 - 2018: Klas af Edholm, Att rista blodörn: Blodörnsriten sedd som offer och ritualiserad våldspraktik i samband med maktskiften i fornnordisk tradition-Jan Ragnar Hagland, Litt om kvinnekroppen i norrøn leksikografisk samanheng_Luke John Murphy, Paganism at Home: Pre-Christian Private Praxis and Household Religion in the Iron-Age North-Ludger Zeevaert, Eine deutsche Zusammenfassung von Njáls saga im Manuskript Rostock Mss. philol. 78/2Heimir Pálsson, Nordens latin-Sigurður Gylfi Magnússon, What Takes Place, When Nothing Happens? The importance of late modern manuscript culturePernille Hermann, rec. av Jón Karl Helgason. Echoes of Valhalla. The Afterlife of the Eddas and Sagas-Mikael Males, rec. av Skaldic Poetry of the Scandinavian Middle Ages, 3: Poetry from Treatises on Poetics, utg. Kari Ellen Gade med Edith Marold-Alexandra Petrulevich, rec. av Studies in the transmission and reception of Old Norse literature. The Hyperborean muse in European culture, red. Judy Quinn \& Adele Cipolla-Olof Sundqvist, rec. av Declan Taggart. How Thor Lost his Thunder. The Changing Faces of an Old Norse God-Vésteinn Ólason, rec. av Poetry in fornaldarsögur. Part 1 and 2, utg. Margaret Clunies Ross

ÅRGÅNG 70 - 2019: Ada Kan, Lars Lönnroth och Agneta Ney, Elena Gurevich (1957-2018). Minnesord-Anders Hultgård, Om Vafprúðnismál-Andras Mortensen, Færeyinga saga som historisk kilde: En vurdering af sagaens ophavssituation og politiske miljø-Guðmundur Ólafsson og Lise Gjedss $\phi$ Bertelsen, Det henrettede par i dobbeltgravhøjene i Kópavogur syd for Reykjavík i ÍslandHubert Seelow, Sjö plánetur i ljóðmaelum: Ein isländisches Gedicht über die Planetenkinder. Mit einem Exkurs: Kritische Anmerkungen zur Laienastrologie und Laienphilologie-Matteo Tarsi, Instances of loanword/native word textual variation in the manuscript transmission of Egils saga Skallagrimssonar and Gísla saga Súrssonar-Marianne Kalinke, rev. of Natalie M. Van Deusen. The Saga of the Sister Saints. The Legend of Martha and Mary Magdalen in Old Norse-Icelandic Translation-Olof Sundqvist, rec. av Anders Hultgård. Midgård brinner. Ragnarök i religionshistorisk belysning

ÅRGÅNG 71 - 2020: Henrik Williams, Jan Axelson in memoriam-Brynja Porgeirsdóttir, The Language of Feeling in Njáls saga and Egils saga: Construction of an Emotional Lexis-Katarzyna Anna Kapitan, Medieval Poetry in Post-medieval Manuscripts: New Perspectives on the Transmission History of Griplur-Lise Gjedss $\phi$ Bertelsen, Om Taustaven fra Pingvellir, Island: Skálholtbispen Ísleifur Gissurarsons hyrdestav?-Már Jónsson, An Icelandic Noctuary of 1794-Ebbe Nyborg and Jette Arneborg, Christian Medieval Art in Norse Green- 
land: Crosses and Crucifixes and their European Antecedents-Olof Sundqvist, Rec. av Triin Laidoner. Ancestor Worship and the Elite in Late Iron Age Scandinavia. A Grave Matter 
